\begin{abstract}
UNIVERSIDADE DE SÃO PAULO
FACULDADE DE FILOSOFIA, LETRAS E CIÊNCIAS HUMANAS DEPARTAMENTO DE TEORIA LITERÁRIA E LITERATURA COMPARADA PROGRAMA DE PÓS GRADUAÇÃO EM TEORIA LITERÁRIA E LITERATURA COMPARADA
\end{abstract}

LARA MARIA ARRIGONI MANESCO

Para além de Penélope: a tessitura mítica e intertextual em contos da literatura brasileira

São Paulo

2017 


\author{
UNIVERSIDADE DE SÃO PAULO \\ FACULDADE DE FILOSOFIA, LETRAS E CIÊNCIAS HUMANAS \\ DEPARTAMENTO DE TEORIA LITERÁRIA E LITERATURA COMPARADA \\ PROGRAMA DE PÓS GRADUAÇÃO EM TEORIA LITERÁRIA E \\ LITERATURA COMPARADA
}

LARA MARIA ARRIGONI MANESCO

\title{
Para além de Penélope: a tessitura mítica e intertextual em contos da literatura brasileira
}

Dissertação apresentada ao Departamento de Teoria Literária e Literatura Comparada da Faculdade de Letras, Filosofia e Ciências Humanas da Universidade de São Paulo para obtenção do título de Mestre em Teoria Literária e Literatura Comparada

Orientadora: Prof ${ }^{a}$ Dra Cleusa Rios Pinheiro Passos

\section{São Paulo}


Autorizo a reprodução e divulgação total ou parcial deste trabalho, por qualquer meio convencional ou eletrônico, para fins de estudo e pesquisa, desde que citada a fonte.

Catalogação na Publicação

Serviço de Biblioteca e Documentação

Faculdade de Filosofia, Letras e Ciências Humanas da Universidade de São Paulo

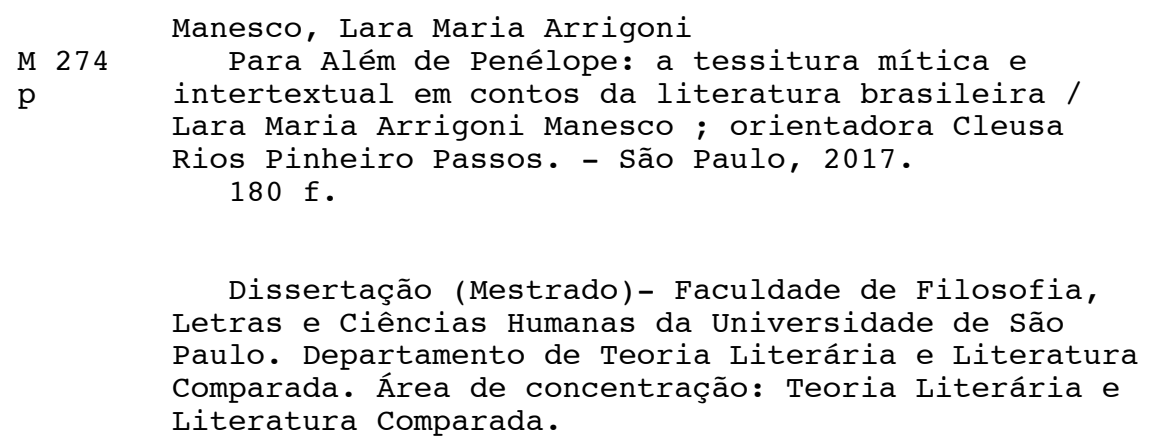

1. Literatura Brasileira. 2. Intertextualidade. 3. Mitos. 4. Literatura Comparada. I. Passos, Cleusa Rios Pinheiro, orient. II. Título. 


\section{Lara Maria Arrigoni Manesco}

Para além de Penélope: a tessitura mítica e intertextual em contos da literatura brasileira

Dissertação apresentada ao Departamento de Teoria Literária e Literatura Comparada da Faculdade de Letras, Filosofia e Ciências Humanas da Universidade de São Paulo para obtenção do título de Mestre em Teoria Literária e Literatura Comparada

Aprovada em:

Banca Examinadora

Profa Dra Instituição

Julgamento Assinatura

Prof $^{a}$ Dra Instituição

Julgamento Assinatura

Profa Dra Instituição

Julgamento Assinatura 


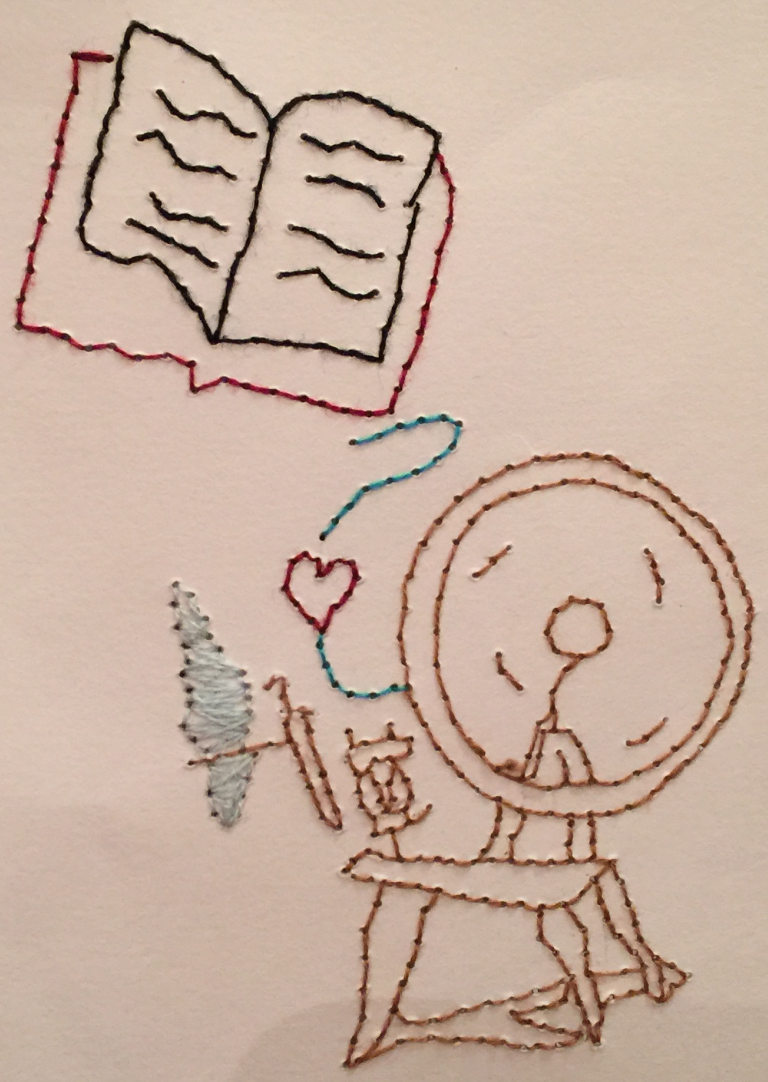





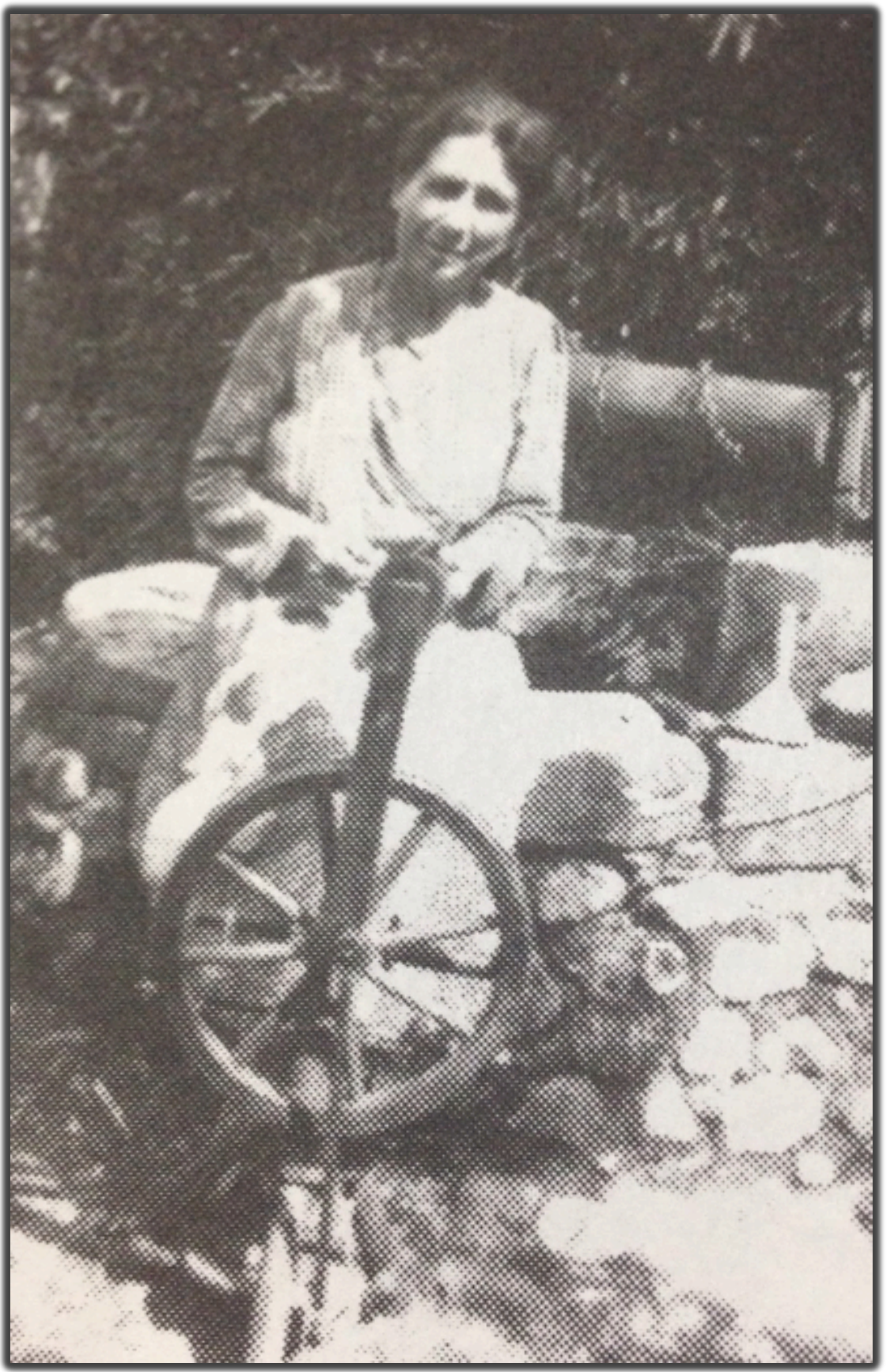

Minha Bisavó e sua roca de fiar 


\section{Lugar 18}

Leio um texto e vou-o cobrindo com o meu próprio texto que esboço no alto da página mas que projecta a sua sombra escrita sobre toda a mancha do livro. Esta sobreposição textual tem por fonte os olhos, parece-me que um fino pano flutua entre os olhos e a mão e acaba cobrindo como uma rede, uma nuvem, o já escrito. O meu texto é completamente transparente e percebo a topografia das primeiras palavras. Concentro-me em São João da Cruz quando o texto fala em Friedrich N.

deixou a proa do barco; passeia aqui o pequeno corpo; atravessa-os com os olhos brilhantes-agudos; anda solto pelo jardim; estabelece-se nas plantas que Ana de Peñalosa regou esta manhã.

Sentou-se então cada um perto do outro, com um texto sobre os joelhos, a brisa descia e impelia as palavras para 0 próximo corpo. Ana de Peñalosa não tinha livro, espetara a agulha no tecido e comtemplava o deambular do peixe.

bordo e penso que sei bordar; não sei como fiz essa associação mas logo depois reflito. Saber e ver. Posso escolher as cores, escolhi as cores das linhas que são rosaavermelhado e vermelho, e escolhi a cor do tecido, o castanho - que, para mim, é esta a cor da reformulação da comunidade. Que bordo é um insecto, sinto o desejo de classificá-lo, de saber-lhe o nome e fico uns instantes a peregrinar interiormente no vasto animal. Com um dedo sobre a linha, prendo também os olhos ao tecido; verifico que vejo um extenso panorama, meus olhos fixos no castanho aveludado parecem voltar- se para todos os lados; soergo a agulha do feltro, o movimento parece-me semelhante ao da escrita, embora inverso.

Não fui eu quem traçou este desenho que bordo mas, percorrendo-o com a agulha, reconstruo o nascimento do acto de desenhar; perco um pouco a noção do tempo como se o meu bordado tivesse vindo de um arquivo e nele estivesse prestes a desaparecer. Situo-me historicamente ao lado de outras mãos que bordariam tecidos de outras épocas. [...] Passo da escrita ao bordado, traduzindo como se ambos fossem a minha palavra; por momentos, esqueço-me mesmo de que bordo, de tal modo os meus dedos se tornaram destros e o meu pensamento, reflectido sobre o bordado, um pensamento. Com um livro escreve-se outro livro. Como um livro é vegetal. (Maria Gabriela Llansol, O Livro das Comunidades, p. 57,58 ) 
A dissimulação da textura pode, em todo caso, levar séculos para desfazer seu pano. O pano envolvendo o pano. Séculos para desfazer o pano. Reconstituindo-o, também, como um organismo. Regenerando indefinidamente seu próprio tecido por detrás do rastro cortante, a decisão de cada leitura. Reservando sempre uma surpresa à anatomia ou à fisiologia de uma crítica que acreditaria dominar o jogo, vigiar de uma só vez todos os fios, iludindo-se, também, ao querer olhar o texto sem nele tocar, sem pôr as mãos no "objeto", sem se arriscar a Ihe acrescentar algum novo fio, única chance de entrar no jogo tomando-o entre as mãos. Acrescentar não é aqui senão dar a ler. É preciso empenhar-se para pensar isso: que não se trata de bordar, a não ser que se considere que saber bordar ainda é se achar seguindo o fio dado. Ou seja, se se quer nos acompanhar, oculto. Se há uma unidade da leitura e da escritura, como hoje se pensa facilmente, se a leitura é a escritura esta unidade não designa nem a confusão indiferenciada nem a identidade de todo repouso; o é que une a leitura à escritura deve descosê-las. Seria preciso, pois, num só gesto, mas desdobrado, ler e escrever. (Derrida, 2005, pp. 07 e 08) 
Às mulheres que teceram com suas vidas o fio da liberdade que nos permitiu escrever, ter voz e ser donas das linhas de nossa mão 


\section{Agradecimentos}

Bastidor que deu suporte ao bordado

Agradeço ao meu Amor pelo apoio, suporte, cuidado e compreensão em cada etapa de elaboração da dissertação e por todos os outros dias de rotina em que vivemos e viveremos o melhor de nossa útil vida. Agradeço pela Colheita desse amor delicado e por cada ponto bordado em nosso dia-a-dia.

Agradeço a minha mãe pelo companheirismo, por sempre acreditar nas minhas asas e me conceder todo o alicerce para um voo tranquilo. Obrigada por ser sempre a primeira a me incentivar e a primeira a estar com o abraço-casa pronto para me receber. Obrigada, sobretudo, pela vida que se renova e por estar bem para acompanhar o término de mais essa etapa.

Agradeço ao meu pai por ter me dado o primeiro encantamento pelas letras nas histórias de antes de dormir, nas cantigas improvisadas e nas brincadeiras com a linguagem. Obrigada pela exigência que nunca me permitiu estar acomodada, pelo carinho transbordante e por todos os labirintos que aprendemos a destecer.

Agradeço a minha irmã, Julia, e ao meu cunhado, Fernando, pela alegria e parceria que imprimem em meu viver. Obrigada pela leveza e amizade de sempre, pelas gargalhadas e trocas, por toda a compreensão pelas minhas ausências e por estarem sempre ali para mim.

Agradeço a minha Nonna, que me ensinou os primeiros pontos e trabalhos com as agulhas, por ter me ensinado e inspirado tanto com a sua história de vida e alegria. Obrigado por nossa viagem a Conegliano em que tanto pude conhecer sobre mim e sobre as nossas raízes. Obrigada pelo nosso elo tão especial que não cabe em palavras e pela fotografia da Bisnonna que abre o trabalho.

Agradeço ao Lucca, ao Pedro, à Lia e à Clara por serem raios de luz em meu viver. Muitas vezes estar com vocês devolveu toda a calma para o meu coração. Vocês são os fios de Ariadne que me tiram de qualquer labirinto.

Agradeço à família que escolhi pelo carinho e suporte de sempre. Agradeço aos amigos-família Cida, Luciano e Laryssa pela partilha da paixão pelas Letras, pelas discussões apaixonadas, pelas risadas e pelos abraços. Agradeço à Cida por ter colocado as agulhas em minhas mãos e me feito descobrir meus enredos e desenredos, pela inspiração, pela primeira leitura de "Desenredo e pelas contribuições nas discussões sobre o texto; à Laryssa pela doçura que imprime ao meu dia-a-dia, pela calma que transmite em seu olhar e pela ajuda fundamental na revisão do texto; ao Luciano por ser mais que um irmão e tecer as delicadezas do carinho em cada um dos meus passos, além da participação na roda de bordado que permitiu que todos os exemplares da dissertação tivessem o seu bordado.

Agradeço ao Colégio Giordano Bruno por ser um espaço de educação transformadora em que sou uma professora tão feliz. Obrigada pelo respeito à ciência e por ser um local em que essa fase de elaboração do trabalho foi tão respeitada. Um agradecimento especial à Laura e a Silvia que tornaram cada dia mais leve com sua amizade, companheirismo e partilha.

Agradeço imensamente a minha orientadora Cleusa Rios Pinheiro Passos, que desde a Iniciação Científica me acolheu com carinho e aprimorou minhas análises com considerações cuidadosas e aprofundadas. Muito obrigada por ser uma orientadora exigente e ao mesmo tempo nos dar toda a confiança e liberdade na construção do trabalho. Obrigada pela amizade, pelas tarde de orientação, pelas discussões riquíssimas, e por todo o suporte ao longo da trajetória. 
Agradeço a Professora Giuliana Ragusa por ter aberto meus olhos de que o meu caminho era a análise literária. Muito obrigada ainda pelas valiosas referências bibliográficas sobre o universo das tecelãs, por todas as incríveis aulas sobre o mundo clássico e pelo carinho de sempre

Agradeço às Professoras $\mathrm{Dr}^{\mathrm{a}} \mathrm{s}$ Sandra Nitrini e Regina Pontieri pela leitura cuidadosa do trabalho e pelos ricos apontamentos em minha Qualificação.

Agradeço à Professora Yudith Rosembaum pelas valiosas sugestões bibliográficas, pelas maravilhosas aulas e palestras sobre Guimarães Rosa e pelas sempre ricas discussões no grupo de Crítica Literária e Psicanálise.

Agradeço às Professoras Dras Nélida Piñon e Maria Inês Marreco pela riquíssima vivência na Cátedra José Bonifácio e pela oportunidade de ter aprendido tanto. Ter podido conhecer pessoalmente a professora Nélida e ouvi-la discutindo a sua obra enquanto eu a estudava foi um grande privilégio. Agradeço a Professora Maria Inês pela leitura tão cuidadosa de meu artigo para o livro da Catédra e pelas importantes sugestões.

Agradeço à CAPES pela bolsa de estudos que permitiu o desenvolvimento do projeto.

Agradeço ao Clube de Leitura Travessia e aos meus alunos e colegas envolvidos pelo oásis a cada quarta-feira.

Agradeço ao curso Revelando Doulas pela reconexão com o universo feminino e com a ancestralidade.

Agradeço aos amigos e à família por serem os alicerces de tudo o que tremulamente construí e por terem sido tão compreensivos em minhas ausências.

Agradeço aos enredos e desenredos da vida que fazem qualquer abismo ser navegável a barquinhos de papel. 


\section{RESUMO}

O trabalho investiga o tema da criação artística em contos brasileiros do século XX por meio da retomada da figura mítica da fiandeira e também indaga de que maneira tal diálogo intertextual com o mito pode ampliar as possibilidades de leitura dos textos em análise. Para tratar tal questão, o recorte apoia-se em narrativas em que a imagem mítica da tecelã é reelaborada como criadora de textos, de receitas culinárias, de tecidos artísticos urdidos em teares modernos, ainda que em constante diálogo com o mito. A pesquisa busca revelar, em um primeiro momento, uma reatualização do mito das tecedeiras em narrativas específicas da literatura brasileira, a saber: "A Moça Tecelã" (2009), de Marina Colasanti, "Desenredo" e "A vela ao diabo" (2001), de Guimarães Rosa, "Colheita" (1997), de Nélida Pinõn, "Penélope" (1998) e "Ponto de Crochê" (2009), de Dalton Trevisan. Por meio da análise comparativa, pretendemos mapear os ecos míticos e intertextuais que dispõem esses textos numa expressiva teia (temático-formal), pois todas as narrativas selecionadas discutem $\mathrm{o}$ ato criativo $\mathrm{e}$ as referências à tecelagem, embora respondam de maneiras diferentes a essas questões.

\section{PALAVRAS-CHAVE}

Mito das Tecelãs; Ato Criativo; Intertextualidade; Contos Brasileiros 


\begin{abstract}
This work analyzes the theme of artistic creation in Brazilian short novel in the 20th century through the resumption of the weaver mythical figure and also inquires how this intertextual dialogue with the myth can increase the reading possibilities of the text analyzed. The research seeks to reveal, in the first moment, a revision of the myth of the weavers in specific narratives of Brazilian literature: "A Moça Tecelã" (2009), of Marina Colasanti, "Desenredo" and "A vela ao diabo" (2001), of Guimarães Rosa, "Colheita" (1997), of Nélida Pinõn, "Penélope" (1998) and "Ponto de Crochê" (2009), of Dalton Trevisan. In order to develop this question, the corpus chosen discusses the mythical image of the weaver as breeder of texts, recipes and artistic tissues weaved in modern looms, even if still keeps constant dialogue with the mythical sources. Through de comparative analyses, we intend to map the mythical and intertextual echoes that order these texts in an expressive web (thematic and formal), because all the selected narratives discuss the creative act and the weaving process, although reply in different ways to those questions.
\end{abstract}

\title{
KEY-WORDS
}

Weavers Myth; Creative Act; Intertextuality; Brazilian short novel 


\section{Sumário}

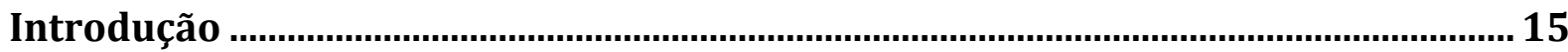

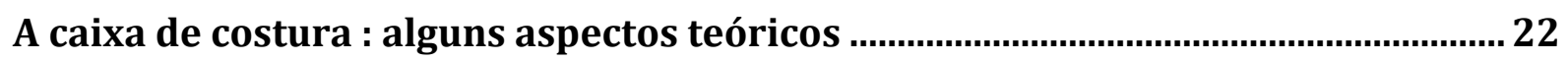

1.1 Entre textos e teias: alguns conceitos da literatura comparada .......................... 22

1.20 tear das Moiras: fios condutores de uma poética do mito............................................. 33

1.3 Tramas do feminino: tecelãs do fuso e da fala ............................................................... 41

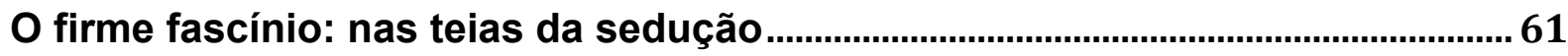

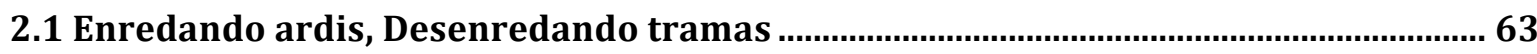

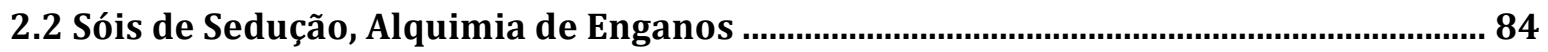

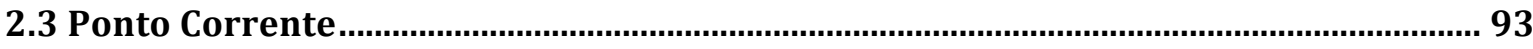

Destecendo Penélope: Entre fabulação e resistência................................................... 96

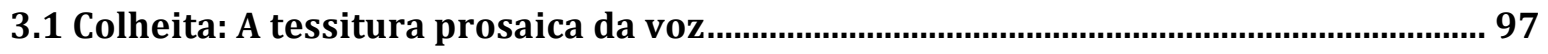

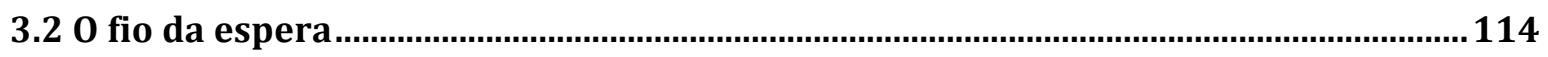

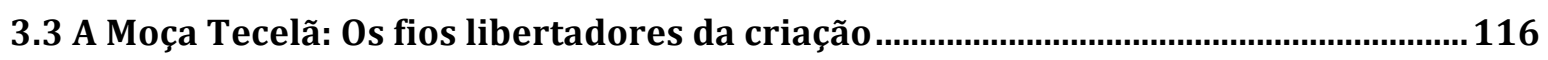

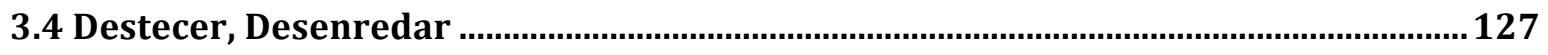

Penélope na cidade: entre Ítaca e 0 asfalto ....................................................129

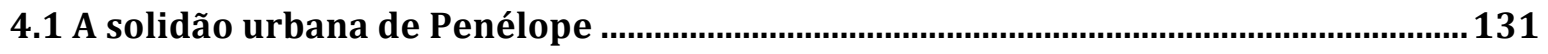

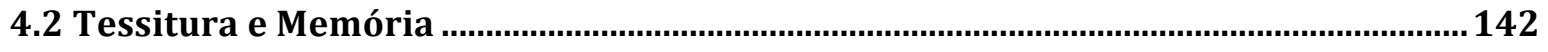

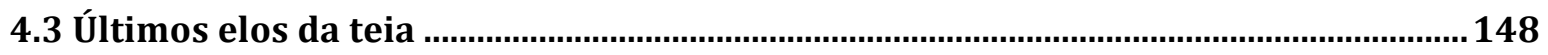

Arremate: da agulha à palavra, da palavra à agulha ..................................................154

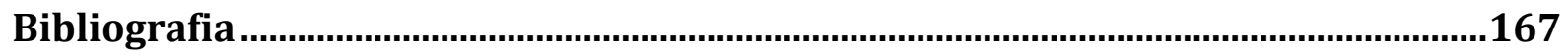

Apêndice: Ariadne e o labirinto: notas sobre a tensão Mito - Modernidade ....................174 


\title{
Introdução
}

\author{
Penélope \\ Desfaço durante a noite o meu caminho. \\ Tudo quanto teci não é verdade, \\ Mas tempo, para ocupar o tempo morto, \\ E cada dia me afasto e cada noite me aproximo.
}

(Sophia de Mello Brayner Andresen)

A pesquisa apresentada investiga o tema da criação artística em contos brasileiros modernos e contemporâneos a partir da relação entre criação literária e tecelagem configurada na reelaboração da figura mítica da fiandeira/ tecelã.

O corpus do trabalho é composto por seis narrativas, divididas em três capítulos, de acordo com suas afinidades temáticas, a saber: "Desenredo" e "A vela ao diabo" (2001), de Guimarães Rosa; "Colheita" (1997), de Nélida Piñon; "A Moça Tecelã" (2009), de Marina Colasanti e "Penélope"(1998) e "Ponto de Crochê" (2009), de Dalton Trevisan. No estudo, será verificada pontualmente a semelhança dos textos selecionados com outros da literatura ocidental, tais como: Odisseia, de Homero; "Circe" (1997), de Julio Cortázar e "A Cortina da Babá Lughton" (2009), de Virginia Woolf, guardando as devidas diferenças entre os autores.

$O$ trabalho vale-se de textos que assimilam e reatualizam o material mítico, imprimindo-lhe novos valores, sobretudo no que tange à criação artística e à apropriação do discurso por parte das mulheres. Em muitos contos desse trabalho, a tecelã é evocada em situação oposta a seu contexto social de origem, qual seja o confinamento da mulher, no óikos, apontando o papel transgressor assumido por ela ao trocar agulhas por palavras.

O objetivo central do trabalho é realizar uma análise temáticocomparatista acerca do mito das tecelãs e sua retomada no século $X X$, sem ignorar questões formais. Visamos a investigar, sobretudo, os elos entre tessitura e ato criativo, recorrendo ao mito grego das tecelãs, a fim de observar de que modo tal imaginário reaparece na literatura moderna como metáfora da criação artística. Procuramos estabelecer um diálogo com diversas tecelãs e fiandeiras: as Moiras, Penélope, Ariadne, Circe, etc. 
Nessa direção, analisamos a criação literária no interior da ficção representada pela metáfora do tecer. Tal aspecto parece relevante, já que a criação literária é um processo muitas vezes absorvido pela própria literatura, tornando-se um de seus topói. Logo, a proposta foi investigar a dupla relação entre os textos do corpus: de um lado, a intertextualidade como recurso dialógico entre obras, que se assemelham a retalhos de uma mesma colcha; de outro, a metáfora do tecer como tema e sua representação do fazer literário.

Trata-se primeiramente de um trabalho de leitura, afinal, "Ler é sempre reler, ligar e religar. É também apostar, neste caso, na iluminação mútua de inúmeros textos, suscetível de revelar vários dos fatores em jogo." (Pageaux, 2011, p. 57). Para explorar tal iluminação mútua, o recorte proposto se apoia em narrativas que resgatam a figura da tecelã, mas a aclimatam a contextos criativos contemporâneos.

Para fundamentar a afinidade texto-tecido, podemos recorrer à etimologia dos termos, os quais partilham a mesma raiz latina, textum ${ }^{1}$, que expressa não só "entrelaçamento, tecido", mas também "contextura (de uma obra)". Contudo, esse parentesco evidencia-se tanto no léxico quanto na pragmática: ponto, linha, tessitura, vocábulos que servem a ambas as esferas, textual e têxtil, desvelando seu entrelaçamento: "várias palavras que se usam para designar o texto e a escrita derivam de outro conjunto de atividades tradicionalmente femininas, a fiação e a tecelagem." (Machado, 2001, p. 15). Narrativa e tecelagem, assim, constituem atividades paralelas:

Contar histórias sempre foi a arte de contá-las de novo, e ela se perde quando as histórias não são mais conservadas. Ela se perde porque ninguém mais fia ou tece enquanto ouve a história. Quanto mais o ouvinte se esquece de si mesmo, mais profundamente se grava nele o que é ouvido. Quando o ritmo do trabalho se apodera dele, ele escuta as histórias de tal maneira, que adquire espontaneamente o dom de narrá-las. Assim se teceu a rede em que está guardado o dom narrativo. E assim essa rede se desfaz hoje em todas as pontas, depois de ter sido tecida, há milênios, em torno das mais antigas formas de trabalho manual.[...]

A narrativa, que durante tanto tempo floresceu num meio artesão no campo, no mar e na cidade - é ela própria, num certo sentido, uma forma artesanal de comunicação. Ela não está interessada em transmitir o "puro em si" da coisa narrada, como uma informação ou um relatório. Ela mergulha a coisa na vida do narrador para em seguida retirá-la dele. Assim imprime-se na narrativa a marca do narrador, como a mão do oleiro na argila do vaso. (Benjamin, 2014, p. 221)

\footnotetext{
${ }^{1}$ Dicionário Etimológico, 2011.
} 
A intersecção linguística, portanto, desdobra-se em laços simbólicos, que fazem da tecelagem muitas vezes uma metáfora da escrita - transposição investigada nos contos selecionados. A tessitura de cada enredo dispõe a memória cultural comum de uma maneira distinta, em função do contexto cultural e da singularidade de seus autores. Dessa maneira, o olhar crítico volta-se para a fatura dos textos e busca investigar de que modo a atmosfera histórico-social, nas quais se inserem tais narrativas, levaram à subversão da analogia fiandeira-mulher como paradigma de fidelidade. Nos textos modernos, temos neo-tecelãs que transgridem as normas patriarcais e assumem as agulhas e as tramas de seus discursos.

Aqui, em geral, o imaginário da tecelã é evocado pelo retorno do mito; entretanto, este não se constitui por mera repetição, mas, sim, pela permanência de alguns traços, e, sobretudo, pela variação do pormenor em cada abordagem. Ao ser revisitado, o mito se transforma e se abre em leques de significância que se tornam mais amplos a cada retomada. A história não só se atualiza, mas também permanece na memória cultural, enriquecida por contextos diferentes.

O primeiro capítulo, "A caixa de costura: alguns aspectos teóricos", objetiva ancorar teoricamente o trabalho por meio da apresentação de alguns aspectos da literatura comparada, e, em seguida, justificar nossa opção metodológica, que se apoia nos pressupostos teóricos do dialogismo, da intertextualidade e da tematologia, buscando iluminar mutuamente as obras em análise. O capítulo ainda resgata os aspectos da poética do mito e traços do mito das tecelãs e fiandeiras relevantes para a interpretação do corpus.

No segundo capítulo, "O firme fascínio: entre enredos e desenredos", foi realizada a análise de dois contos de Guimarães Rosa publicados na obra Tutameia (2001): "Desenredo" e "A Vela ao Diabo". Em "Desenredo", podemos observar que o protagonista Jó Joaquim assemelha-se a uma Penélope apequenada que tece e destece a própria narrativa, enquanto Livíria reelabora a linhagem das tecelãs fatais iniciada por Pandora. Já em "A vela ao diabo" (2001) as tecelãs aparecem nas figuras de Zidica, herdeira de Penélope, e Dlena, herdeira de Pandora.

O terceiro capítulo do trabalho, "Destecendo Penélope: entre fabulação e resistência", objetiva analisar o papel transgressor instalado pela mulher-fiandeira em narrativas brasileiras do século XX. A figura da tecelã aparece na qualidade de mulher criadora, que se liberta da amálgama patriarcal e pode assumir sua voz ao substituir agulhas por palavras. 
O quarto capítulo, "Penélope na cidade: entre Ítaca e o asfalto", é dedicado a dois contos de Dalton Trevisan, "Penélope" (2009) e "Ponto de Crochê" (2009). As narrativas de Dalton reatualizam o mito das tecelãs no espaço urbano e, portanto, em um espaço degradado muito distante do mítico-heroico. Esse dado será central nas análises, uma vez que ancora o mito no apequenamento burguês e no mundo urbano. Assim, parece que os contos paralelamente invocam e corroem a narrativa mítica.

O tema recortado para a análise já recebeu atenção no meio acadêmico, porém na maioria das ocorrências a comparação centra-se em uma tecelã específica, isto é, temos dissertações e teses em que a figura de Penélope, ou das Moiras ou de Ariadne é o centro de comparação. Discorreremos sobre alguns desses trabalhos, sem a pretensão de contemplar todos eles.

Exemplo da retomada de uma tecelã específica é a tese de doutorado de Denise de Carvalho Dumith (2012), O mito de Penélope e sua retomada na literatura brasileira: Clarice Lispector e Nélida Piñon. Nela, a autora analisa a releitura da figura mítica em um conto e um romance de cada uma das autoras. Há também a tese de doutoramento de Lúcia Castello Branco (1990), A traição de Penélope, em que se estudam as afinidades entre o gênero memorialista e uma escritura do feminino por meio dos diários de grandes autoras: Virgínia Woolf, Florbela Espanca e Anaïs Nin.

Ambas as teses focam a figura de Penélope em sua relação com o discurso feminino, mas sem abordar as semelhanças entre tecelagem e produção artística, que desejamos enfatizar neste trabalho. Além disso, aqui se trabalhará com o mito das tecelãs de maneira mais ampla, passando por Penélope, mas envolvendo outras tecedeiras, como Pandora, Circe, Calipso, Aracne e as Moiras.

Vale citar ainda a dissertação de Mara Lúcia David (2001), A presença do mito na ficção de Marina Colasanti, que tangencia o mito das tecelãs, porém dentro de um quadro mais amplo da permanência mitológica. A autora mapeia os diálogos estabelecidos por Colasanti com um amplo espectro de mitos gregos: Narciso, Eco, Penélope, entre outros, debruçando-se sobre a obra de Marina, mas sem contemplar uma análise comparativa do tema da tecelagem.

Encontramos ainda a dissertação, em Literatura Portuguesa, de Luciana da Silva Bezerra (2006) Penélopes do contemporâneo na escrita de Juana Ruas e Lídia Jorge. $\mathrm{O}$ trabalho focaliza um romance de cada uma das autoras, aparecendo a 
fiandeira como figura condutora: Corpo colonial (1981), de Juana Ruas e O dia dos prodígios (1984), de Lídia Jorge. Ainda que o gênero escolhido para o corpus e a nacionalidade das obras sejam diferentes, detectamos afinidade intelectual com a proposta, uma vez que ele busca olhar no percurso de tais tecelãs tanto o espaço de reivindicação do feminino quanto a escritura, elaborando um diálogo abrangente com outras tecelãs que não Penélope. O que difere, entretanto, da nossa abordagem é que a tecelã é identificada com as autoras das obras selecionadas, enquanto, em nosso recorte, a tessitura criativa é própria das personagens analisadas, para além de seus autores.

É natural que tal tema já tenha sido estudado, pois resgata um dado importante do chão cultural do Ocidente. A existência de escritos que reelaboram a presença das tecelãs em diversos gêneros e culturas reforça nossa hipótese de que o retorno dos mitos, na sociedade contemporânea, ocorre de forma sistemática, tentando resgatar e ressignificar o nosso elo com as narrativas primordiais.

A contribuição deste trabalho parece consistir na abordagem de contos brasileiros do século $X X$ e na análise da tecelagem enquanto metáfora para a escritura. $\mathrm{Na}$ análise comparativa, investigaremos o princípio da intertextualidade como processo de "costura" de textos, procurando sublinhar uma teia de relações mútuas, não-hierárquicas em que narrativas que discutem o mesmo referencial mítico possam iluminar-se reciprocamente. Também vale ressaltar o objetivo de resgatar o sentido social da tecelagem para perceber os deslizamentos semânticos que aproximam tessitura e escritura, permitindo que as agulhas - antes ligadas ao confinamento feminino - passassem a escrever a história de sua libertação.

Mesmo que o diálogo no corpus nem sempre se dê por meio da presença explícita da outra obra, a sustentação teórica que mais se aproxima da relação estabelecida entre os textos é a da intertextualidade. A pesquisa, portanto, buscou suporte nos postulados de Mikhail Bakhtin (1997), Julia Kristeva (1969), Laurent Jenny (1979), Claudio Guillén (1985), Raymond Trousson (1981) e Tiphaine Samoyault (2008). Para amparar a investigação mitocrítica, mais especificamente, recorremos, por vezes, ao pensamento de Gilbert Durand (2002), uma vez que o autor fornece um vasto panorama dos símbolos e mitos, estudados em sua amplitude e não como formas estáticas.

Em suma, metodologicamente, apropriamo-nos não só de aspectos da teoria da intertextualidade, mas também da tematologia (Guillén,1985) para buscar uma 
leitura aprofundada dos textos ficcionais, tendo a consciência de que sua interpretação plena é impossível.

Nossa proposta metodológica contempla o cotejamento dos textos, a fim de investigar se a intertextualidade, o dialogismo e a recorrência temática constituem recursos para estudos críticos verticalizados para indagar se é possível aprofundar a leitura interpretativa colocando-se os textos em relação. Além disso, pretende-se sublinhar de que maneira tais contos se articulam, privilegiando o diálogo das obras em forma de teia para criar uma cadeia de vínculos mútuos e não hierárquicos. Em geral, o cotejamento proposto - embasado no entrelaçamento de fios dialógicos procura equilibrar a análise de textos e o contexto cultural por meio de recorrências e alterações compositivas.

Pretendeu-se ainda compreender a retomada do tema da fiandeira na literatura ocidental do século $X X$ e suas diferentes formas textuais. Outro fator que torna a figura da fiandeira objeto de análise é seu elo intrínseco com o feminino, e, consequentemente, com traços da presença da mulher na literatura do século $X X$.

Nosso estudo ainda parece relevante uma vez que revisita a noção de intertextualidade, a fim de reconsiderá-la à luz das estruturas míticas. Consoante Samoyault, o mito pode ser o ponto chave para compreendermos de que modo o intertexto, mais do que uma atualização, representaria o movimento de continuidade da memória cultural.

Além disso, parece imperativo estabelecer novos contatos no escopo dos estudos comparativos, que já dialogam extensivamente com disciplinas como a pintura, o cinema, o teatro. Entretanto, os estudos concernentes às narrativas míticas e simbólicas merecem, ainda, desenvolvimento no contexto universitário. Em se tratando de narrativas centrais para a constituição da tradição e da cultura de todas as civilizações, o estudo do mito enquanto expressiva unidade discursiva mostra-se importante para que possamos investigar o conteúdo/forma na qualidade de memória cultural e literária, mesmo porque a poética e a ficção contemporâneas apontam para uma revalorização estética do mito e, nesse campo, cabem ainda olhares críticos.

Por fim, este trabalho pretende contribuir para o enriquecimento da fortuna crítica referente às obras escolhidas, garantindo nova reflexão analítica não só sobre textos já bastante abordados, como "Desenredo" (2001), mas também acerca de 
contos cujas propostas críticas apresentam-se mais timidamente, como "A Moça Tecelã" (2009) e "Colheita" (1997). 
As três parcas

As três Parcas que tecem os errados

Caminhos onde a rir atraiçoamos

O puro tempo onde jamais chegamos As três Parcas conhecem os maus fados.

Por nós elas esperam nos trocados

Caminhos onde cegos nos trocamos Por alguém que não somos nem amamos Mas que presos nos leva e dominados.

E nunca mais o doce vento aéreo Nos levará ao mundo desejado

E nunca mais o rosto do mistério

Será o nosso rosto conquistado Nem nos darão os deuses o império Que à nossa espera tinham inventado.

(Sophia de Mello Breyner Andresen)

\title{
1.1 Entre textos e teias: alguns conceitos da literatura comparada
}

\author{
Um galo sozinho não tece uma manhã: \\ ele precisará sempre de outros galos. \\ De um que apanhe esse grito que ele e o lance a outro; \\ de um outro galo que apanhe o grito de um galo antes \\ e o lance a outro; e de outros galos que \\ com muitos outros galos se cruzem \\ os fios de sol de seus gritos de galo, \\ para que a manhã, desde uma teia tênue, \\ se vá tecendo, entre todos os galos. \\ (João Cabral de Melo Neto)
}

A tessitura de uma dissertação, como a manhã assinalada por João Cabral, é permeada de muitas vozes. Ecos que fazem coro a nossos anseios teóricos e analíticos e nos guiam pelas veredas da interpretação. Vozes do presente e vozes pretéritas às quais recorremos para aceitar ou para debater. Abrir a caixa de costura exige, portanto, que separemos os fios teóricos das discussões apresentadas, que marquemos, no bastidor, a potencialidade dos traços a serem bordados, que orientemos o ziguezaguear da agulha a partir das vozes de tecelãs mais experientes.

Para tanto, é preciso refletir acerca de alguns conceitos operacionais da Literatura Comparada que podem dar suporte às análises literárias propostas. 0 
campo da literatura comparada desperta paixões: uma prática que encadeia os grandes autores em uma sinfonia de galos, que, com seus textos-manhã, compõem em luz-balão, a tradição. Porém, nem sempre a literatura adere ao canto já estabelecido, ela irrompe em movimento pendular entre permanência e ruptura: em sua gênese, toda narrativa resgata a biblioteca fabulativa nutrida pelo imaginário humano, mas a aclimata aos anseios específicos de seu tempo e de sua trama. $\mathrm{Na}$ esteira da crítica, afirma Leyla Perrone-Moisés:

(...) literatura se produz num constante diálogo de textos, por retomadas, empréstimos e trocas (...). A literatura nasce da literatura; cada nova obra é uma continuação, por consentimento ou contestação, das obras anteriores, dos gêneros e temas já existentes. Escrever é, pois, dialogar com a literatura anterior e contemporânea. (Perrone-Moisés, 1990, p. 94)

A arte literária constantemente recorre aos seus antepassados para produzir a sua matéria poética. Nesse sentido, a literatura, bem como as musas que a inspiram, é filha de Mnemôsine. Nasce da interação do tempo e da memória, carregando em cada palavra reminiscências e reconstruções: "Escrever é pois reescrever... Repousar nos fundamentos existentes e contribuir para uma criação continuada." (Samoyault, 2008, p. 77)

Como não reconhecer no ciúme doentio de Bentinho os ecos do mouro de Shakespeare? Será possível ignorar a filiação de Riobaldo ao ciclo fáustico ou a ligação de Lucíola e Marguerite Gautier? Em contrapartida, Bento Santiago não é Otelo e os seus dilemas não são parafrásticos.

Em nossa leitura, procuraremos elucidar de que maneira alguns textos brasileiros contemporâneos resgatam o mito das tecelãs, dialogando com toda a tradição grega. Penélope, As Moiras, Aracne comparecem às narrativas atuais, mas já não são as figuras míticas de outrora. Aparecem reformuladas e vestindo novas roupagens em que, muitas vezes, misturam-se traços de mais de uma tecelã.

O comparatista é um construtor de pontes não só entre textos, mas também entre tempos. A analogia é sua ferramenta central de trabalho, uma vez que seus objetos nunca estão dados, devem ser construídos pelo olhar sensível: "Construir, pois, em estado bruto, nada está dado ao comparatista, uma vez que a relação resta por se compor, estabelecer, justificar." (Pageaux, 2011, p.36).

A análise comparativa se estabelece pelo olhar singular do crítico, que confecciona, a partir de uma relação muito particular com o texto, uma teia dialógica para articular narrativas aparentemente díspares. Tal teia captura, feito armadilha, 
um recorte de trabalho que coloca as tramas em contato. O comparatista, com um trabalho de aranha, cria a partir do seu corpo as fibras que desenharão um espaço de diálogo, respondendo ao grito do texto: relaciona-me ou te devoro.

Nessa perspectiva, o fazer comparatista é, metaforicamente, análogo ao da tecelã: é necessário reconfigurar os percursos narrativos a partir do diálogo e lhe atribuir novos sentidos. Enquanto artesão da palavra, o crítico da comparada vê-se no papel de tecer relações entre textos, entre artes e entre campos distintos - a fim de que tais entrelaçamentos lancem novos prismas sobre a obra e inaugurem novas maneiras de lê-la.

Nesse processo, instaura-se inevitavelmente, consoante às propostas de Bakhtin, a presença da alteridade. É o outro que me chama para o diálogo e para a analogia. O outro que reconheço no novo, que coloca os textos e as obras artísticas em contato. Segundo Laurent Jenny, o intertexto, quando localizado pelo leitor, "faz estalar a linearidade do texto" (Jenny, 1979, p. 21) e, assim, inaugura uma bifurcação: ou o leitor reconhece o intertexto e ressignifica a narrativa, ou segue o texto sem aquela informação e chega a uma interpretação parcial. Portanto, a intertextualidade permite a atribuição de outros sentidos pela luz do diálogo sentidos que ficariam na penumbra, caso se fizesse uma análise textual isolada.

Contudo, o trabalho comparatista não pode se limitar ao mapeamento de pontos de contato entre textos. O seu grande desafio é chegar a um cotejo que aqui chamarei de hermenêutico, já que requer uma atitude que, além da identificação de ecos e dissonâncias, articula-os, de tal modo que se amplie a possibilidade de leitura das camadas do texto e se estabeleçam leques de sentido nas partes e no todo da narrativa lida: "As dimensões de um universo ficcional podem encontrar-se consideravelmente ampliadas pelo recurso a índices intertextuais." (Samoyault, 2008, p. 99).

Nessa direção, a imagem da teia concentra uma série de noções expressivas para o comparatismo: o diálogo, o entrecruzamento de fios e enredos, a circularidade, a oscilação entre vazios e preenchimentos, a ambivalência e a nãohieraquização. Por isso, propusemos para essa pesquisa uma modalidade particular de diálogo, na esteira dos postulados de Gilbert Durand (2002): o diálogo intertextual em forma de teia.

Durand, teórico da mitocrítica, investiga de que maneira as imagens arquetípicas, que compõem o imaginário humano, podem ser dispostas em forma de 
constelação e organizadas em regimes, consoante suas funções simbólicas. A constelação sugere um agrupamento por afinidade, no entanto não se baseia em hierarquização.

Justifica-se a opção pela imagem da teia porque ela resgata com muita propriedade a ideia de "relação" e, mais, pressupõe uma articulação não-linear entre as narrativas, ainda que exista um centro irradiador de sentido. Conforme os postulados de Laurent Jenny, "A intertextualidade designa não uma soma confusa e misteriosa de influências, mas o trabalho de transformação e assimilação de vários textos, operado por um texto centralizador, que detém o comando do sentido." (Jenny, 1979, p. 14). Neste trabalho, o mito das tecelãs funciona como a matriz literária que detém o comando de sentido, contudo, o conto "Desenredo" (2001), funcionará como o primeiro círculo de nossa teia e, portanto, os demais textos do corpus serão organizados ao seu redor. $\mathrm{Na}$ análise, poderemos observar os deslocamentos e transformações sofridos por parte da narrativa mítica no século $X X$.

Consideramos fundamental cotejar os textos do corpus não apenas com os referenciais míticos, mas também estabelecer 0 diálogo com textos contemporâneos, a fim de perceber os possíveis movimentos de contestação e aceitação dentro do tema da tecelã, que, embora assimilado pela literatura recente, não desempenha a mesma função empreendida no contexto da Grécia Antiga.

Ao assumir uma posição comparatista, optamos, entre vários conceitos teóricos, pela via da intertextualidade. Assim, não remeteremos às noções de "fonte" e "influência" na concepção comparatista tradicional, que constituiu a base da literatura comparada até o século $\mathrm{XIX}^{2}$.

Ao longo do século $X X$, autores e intelectuais de diversas partes do mundo voltaram-se para a literatura comparada, contudo foi no centro dos estudos linguísticos franceses que se formulou a teoria da intertextualidade, que iria alterar profundamente a metodologia dos estudos comparatistas.

\footnotetext{
${ }^{2}$ Tal visão ortodoxa circunscrevia a análise comparativa à investigação causal da presença de um autor em outro, sem necessariamente investigar de que forma a reelaboração desse material foi realizada. Embora grandes críticos, como Antonio Candido, tenham operacionalizado tais conceitos de maneira singular, transformando a influência em influxo libertador, em nossa pesquisa optamos por trazer à luz a noção de "presença" de um autor em outro, intermediada pelo entrecruzamento de fios dialógicos a fim de evitar o eco positivista que os conceitos "fluviais" (fonte e influência) podem evocar.
} 
A concepção de Kristeva acerca de intertextualidade advém do dialogismo formulado pelo teórico russo Mikhail Bakhtin, cuja obra foi traduzida para o francês por Kristeva. Contudo, o dialogismo é um conceito mais amplo, entendido enquanto propriedade inerente do discurso. Na metáfora proposta por Bakhtin, nenhum de nós é Adão, tomando a palavra inicial, e, portanto, apropriamo-nos dos discursos alheios para construir a nossa identidade discursiva. Na poética bakhtiniana, toda palavra introduz um diálogo com outros textos e instaura uma multiplicidade de discursos, pois se configura como um lugar dinâmico em que ocorrem trocas.

Desse modo, o dialogismo bakhtiniano perpassa todo o trabalho, uma vez que buscamos ecos e contatos entre um elemento da cultura grega e da literatura brasileira, logo, investigamos a alteridade. Contudo, por seu caráter mais abrangente, o conceito não contempla alguns aspectos específicos da relação entre textos, questão posteriormente explorada por Julia Kristeva.

O termo intertextualidade foi cunhado por ela em seu artigo-pilar: "A palavra, O diálogo e o romance" (1974). A formulação da autora data da década de 60 , quando se buscava uma ciência do literário, engendrada pela concepção imanente do texto defendida pelos estruturalistas. Assim, o vocábulo nasceu no bojo de um pensamento que buscava um sistema de relações entre signos, sintagmas e textos, mais próximo dos estudos linguísticos do que literários.

Nesse artigo fundamental, Kristeva postula a compreensão do texto literário em analogia a um mosaico de citações, inerentemente dialógico: "Todo texto se constrói como um mosaico de citações, todo texto é absorção e transformação de um outro texto. Em lugar da noção de intersubjetividade instala a noção de intertextualidade e a linguagem poética lê-se pelo menos como dupla." (Kristeva, 1974, p. 64). Esse conceito, ao evocar a imagem do mosaico, recoloca os textos em contato análogo à colcha de retalhos, imagem bastante relevante no contexto de análise de fiandeiras e tecelãs, reiterando o vínculo texto-tecido enfatizado.

Diversos autores resgataram as ideias centrais de Kristeva, incorporando importantes ponderações a seus postulados teóricos. No Brasil, vale destacar as reflexões de Leyla Perrone-Moisés (1990), em que a autora sublinha elos entre a intertextualidade e a antropofagia de Oswald de Andrade. Para ela, os pressupostos poéticos do manifesto antropofágico refletem a intertextualidade aclimatada ao contexto brasileiro. 
As narrativas brasileiras analisadas por nós devoram a literatura grega e suas repercussões na literatura ocidental, mas a aclimatam ao universo moderno brasileiro, desvelando suas estruturas patriarcais, suas cidades pequenas que mimetizam aldeias, sua burguesia urbana, seus paradoxos de progresso e traços de arcaísmo. Desse modo, conforme já postulado pela crítica, o arcaico e moderno coexistem - hipótese da qual partilhamos.

A mudança de registro - do mito e da épica para o conto; da cultura grega para a brasileira e da época arcaica para a moderna - instaura uma série de deslocamentos nos modos de representação da tecelã. Nessa direção, alguns aspectos históricos serão destacados, já que o texto literário carrega tensões e interesses específicos de seu tempo. Nesse sentido, em nosso trabalho, encontramos a temática da esfera mítica no enredo do conto. Por isso, faz-se necessário investigar brevemente o que levou a passagem da épica, que contemplava o enredo mítico, ao conto moderno.

Segundo Lukács (1999), a primeira diferenciação deu-se entre épica e romance, gênero fundado "na contraposição entre o caráter poético do mundo antigo e o caráter prosaico da civilização moderna, ou seja, burguesa." (Lukács, 1999, p. 89). O crítico - assim como Walter Benjamin - afirma que o surgimento do romance relaciona-se à individualidade do mundo burguês, enquanto a épica configurava-se como um gênero voltado para a coletividade e para as experiências compartilhadas. Lukács reforça que a poesia épica e o romance aspiram aos mesmos fins, no entanto as condições materiais e históricas da sociedade burguesa aniquilam a possibilidade da criação épica e, portanto, geram um produto estético totalmente diverso. ${ }^{3}$ Trata-se, assim, de uma reconfiguração do narrar (outrora eminentemente épico), ditada a partir do contexto histórico e das novas situações sociais em que se localizam as produções literárias: do geral do épico ao individual do romance.

Walter Benjamin (2009) estabelece as diferenças entre romance e narrativa, ambos derivados da epopeia, levando em consideração o manejo distinto da memória. O filósofo considera que a épica condensa em sua natureza tanto a narrativa quanto o romance, ambos edificados a partir da rememoração, a chamada "musa épica". Esta, fundadora do fazer narrativo, condensaria, a priori, ambas as manifestações e ainda outras mais. Com a lenta separação, uma marca distintiva

\footnotetext{
${ }^{3}$ Cf. LUKÁCS. G. "O romance como epopeia burguesa." Ad Hominem, vol 1, 1999, pp. 92-93
} 
aflora entre narrativa e romance. Enquanto a primeira apresenta em seu cerne a breve memória, a referência da outra (o romance) é marcada pela permanência temporal mais acentuada, ou seja, pela memória perpetuadora:

Mnemosyne, a que rememora (die Erinnernde), era para os gregos a musa da poesia épica. [...] a epopeia propriamente dita, contém em si, por uma espécie de indiferenciação, a narrativa e o romance. Quando, no decorrer dos séculos o romance começou a emergir do seio da epopeia, ficou evidente que nele a musa épica - a rememoração - aparecia sob uma forma totalmente distinta do que na narrativa.

A rememoração funda a cadeia da tradição, que transmite os acontecimentos de geração em geração. Ela corresponde à musa épica no seu sentido mais amplo. Ela inclui todas as variedades específicas da forma épica. Entre elas, encontra-se em primeiro lugar a encarnada pelo narrador. Ela tece a rede que em última instância todas as histórias constituem entre si. Uma se liga à outra, como demonstraram todos os grandes narradores, principalmente os orientais. Em cada um deles vive uma Scherazade, à qual ocorre uma nova história em cada passagem da história que está contando. (Benjamin, 2014, p. 227)

Quanto ao gênero conto, parte da crítica o considera oriundo de uma matriz popular eminentemente oral e que se consolidou como conto moderno no século XIX, a partir dos postulados teóricos de Edgar Allan Poe, cuja proposta defende que um dos atributos favoráveis ao conto é sua brevidade em relação ao romance: por ser curto, abarca o que ele chamou de impressão de totalidade, o que garante a seu autor apresentar um desígnio preestabelecido ao leitor de um só fôlego, com rigor. Logo, para ele, a diferença entre o conto e o romance não se limita apenas ao tamanho de ambos. No primeiro, há a necessidade do acontecimento preciso, com cada palavra convergindo para o fato narrado, sem margens a comentários a posteriori. Assim, a diferença entre conto e romance não se atém apenas à forma, pois, ao primeiro cabe não somente ser curto, mas ser intenso, embora seja econômico.

Julio Cortázar também defende que o ponto de partida para a elaboração de um conto é ter consciência de sua concentração. Traçando uma analogia entre fotografia e cinema, o escritor postula que o conto está para aquela assim como o romance está para o cinema, ou seja, a instância do conto consiste num recorte, que se abrirá para uma realidade mais ampla. Trata-se, tanto na fotografia quanto no conto, de levar em consideração somente o que é significativo, a possibilidade de abertura para aquilo que é mais amplo. No romance e no cinema, o movimento é inverso, isto é, ambos valorizam a acumulação, o acréscimo gradativo - e, portanto, horizontal - de informações. O conto, em um percurso contrário, contempla aquilo que é incisivo e, portanto, vertical. Para Cortázar, um bom conto abre possibilidades 
de expansão a partir de seu argumento: ele oferece uma realidade para além do que está sendo lido.

Essa "ponte" que, segundo Cortázar, o bom conto oferece ao leitor, encontra na concisão a abertura para a projeção da vida. Ele lembra ainda que o tema pode ser importante para o escritor e receber menos atenção do leitor, ou vice-versa. No entanto, é preciso garantir a concisão e a possibilidade de gerar sentido além de si mesmo. Alfredo Bosi concorda com a brevidade do conto, acrescentando que ele se vale de temas que ora tangem a vida real, ora visitam a esfera imaginária. No entanto, a linguagem do conto requer sensibilidade e alude àquilo que é mais significativo, independente de sua temática.

$\mathrm{Na}$ seleção do corpus aqui analisado, considerou-se o conto como uma esfera capaz de abarcar temas relacionados à vida real, palpável e, portanto, ancorada na esfera social, bem como possibilitar a exploração da "sondagem mítica do mundo", conforme defende Bosi. Por propiciar o aspecto difuso, o conto possibilita diversas temáticas, dentre elas a mítica, "sensível, tensa e prenhe de significação". Revisitar a temática das fiandeiras na configuração da construção feminina, revela que o material mítico está posto como recorrente no meio social, embora repleto de contornos diáfanos ${ }^{4}$ :

Parece mais produtivo estabelecer vínculos entre literaturas que não se constituem a partir do vazio, sendo, portanto, historicamente motivadas e oriundas de contextos culturais específicos. Dessa maneira, a reatualização da figura das tecelãs na esfera da literatura contemporânea apresenta dois objetivos: a retomada do fazer criativo da escrita e a busca de um lugar enunciativo que subverta a ideia de passividade ocupado pela mulher-tecelã até o século XIX em sociedades patriarcais.

$\mathrm{Na}$ esteira da crítica, Samoyault (2008) recobra a prática intertextual como funcionamento da memória de uma época, pois a arte explicita aquilo que um período, classe e sociedade escolhem resgatar e também o que escolhem suprimir.

\footnotetext{
4 “É muito provável que o conto oscile ainda por muito tempo entre o retrato fosco da brutalidade corrente e a sondagem mítica do mundo, da consciência ou da pura palavra. Essas faces do mesmo rosto talvez componham a máscara estética possível para os nossos dias; e a literatura, enquanto literatura-para-aliteratura não tem meios de superá-la. Poderá representá-la, exprimi-la, significá-la. E vivê-la e sofrê-la, até desafiá-la."(Bosi, 1997, p. 22)
} 
O contexto histórico-social será incorporado ao trabalho à medida que se revele relevante para iluminar o texto literário.

Um olhar matizado sobre o fenômeno literário parece garantir que Ícaro supere as barreiras do labirinto, sem se afogar no mar Cáspio, destacando a singularidade, sem que se perca a multiplicidade. Essa é a visão teórica de Claudio Guillén (1985). Em seu livro Entre lo uno y lo diverso, publicado em 1985 e reeditado em 2005, o autor aborda o movimento pendular que orienta a história literária. A íntima relação entre permanência e ruptura é fundamental para compreender a retomada do mito como procedimento estético. Afirma Guillén que há um vínculo entre continuidade e troca na história da literatura, por isso alguns temas literários são continuamente recobrados na produção de novos textos.

Para o comparatista, há associação do devir e da permanência através dos temas que constituem lugares-comuns do acervo universal. Cada escritor revisita tais temas ao criar obras literárias, reformulando-os de acordo com a sociedade em que está inserido. Assim, as estruturas permanecem em realizações múltiplas que articulam unidade e diversidade. Raymond Trousson também enfatiza a importância do momento histórico e da sociedade na reelaboração temática:

Cada época possui uma mitologia particular, própria para exprimir suas
preocupações, para refletir suas aspirações e suas inquietudes; o tema
sempre multifacetado e suscetível a renovação, assume maior ou menor
importância segundo a maior ou menor adaptação de sua estrutura interna
às exigencies do novo pensamento. (Trousson, 1981, p. 98, tradução
nossa) ${ }^{5}$

O autor entende por tema "uma parte das experiências ou crenças humanas que em determinado momento histórico certo escritor converte em canal efetivo da sua obra e, logo, em componente do repertório temático-formal que torna possível e que propicia a escritura literária de seus sucessores." (Guillén, 2006, p.56). Nesse sentido, sua visão aproxima-se da de Raymond Trousson para quem: "Nós podemos considerar que os temas continuam sendo a representação simbólica de uma situação humana exemplar, de um caso particular elevado ao âmbito universal."6 (Trousson, 1981, p. 43, tradução nossa).

\footnotetext{
5 “Chaque époque se fait une mythologie particulière, propre a exprimer ses préoccupations, à refléter ses aspirations et ses inquiétudes; le thème, toujours protéiforme et susceptible de renouvellement, prend plus ou moins d'importance selon que sa structure interne s'adapte plus ou moins bien aux exigences de la pensée nouvelle."(Trousson, 1981, p. 98)

6 "On peut considérer que les thémes sont demeures la représentation symbolique d'une situation humaine exemplaire, d'un cas particulier haussé à la portée universelle"(Trousson, 1981, p. 43)
} 
Guillén considera tal conceito concomitantemente ativo e passivo, já que opera não só como incentivo integrador (recorrências), mas também como objeto de modificação (alterações). Além disso, destaca as relações estabelecidas pelo tema triádicas, porque ele (o tema) articula-se com a vida, com a história da cultura e com suas próprias variações. Essa visão, postulada pelos formalistas russos, vai ao encontro daquela de outros pensadores contemporâneos, por exemplo a de DanielHenri Pageaux (2009) ${ }^{7}$.

Raymond Trousson, em sua obra Thèmes et Mythes, investiga a tematologia diferenciando-a do mito e dos motivos. Trousson opta por não empregar o termo mito em sua análise, já que afirma que a partir do momento que o mito entra na esfera literária ele perde seu papel no universo tradicional, e, portanto, o uso do termo não seria produtivo do ponto de vista metodológico: "A abertura indefinida do mito, matéria bruta, opõe-se ao fechamento da obra literária, produto acabado [...] Nós iremos tratar, portanto, de literatura e não de mitos."8 (Trousson, 1981, p. 20, tradução nossa). ${ }^{9}$ Para o autor, os motivos são conceitos amplos, como a revolta ou a sedução, enquanto os temas seriam a individualização de tais elementos que passariam a ser representados por protagonistas como Ulisses, Medéia, Prometeu etc.

Segundo Trousson, o tema faz com que o autor tenha que lidar com o chão cultural de seu público, de modo que "ele deve respeitar a tradição que pesa sobre ele como um fardo do qual ele não pode despojar-se, sob o risco de trair suas próprias intenções." ${ }^{10}$ (Trousson, 1981,p. 78, tradução nossa). O autor ainda investiga a permanência dos mitos ao longo da história como parte constitutiva do chão cultural que orienta a humanidade:

O tema é um fio condutor, eterno através do tempo, carregado ao longo dos séculos pela rota ilimitada de todo o espólio artístico e filosófico acumulado pelo aventureiro ser humano; o é porque preserva e restitui através de suas inomináveis transmutações, algumas constantes, algumas preocupações

\footnotetext{
${ }^{7} \mathrm{O}$ tema pertence ao texto em sua singularidade, do qual é um elemento estruturante. $O$ tema é um elemento textual, mas também transtextual, espécie de matéria indivisa na qual nos parece que a imaginação tem poder de escolha (...) Assim, o tema interessa tanto ao imaginário singular de um escritor quanto a um imaginário coletivo, ou melhor, social. (Pageaux, 2009, p. 187)

8 "A l'overture indéfinie du mythe, matière brute, s'oppose la clôture de l'oeuvre littéraire, produit fini [...] Nous avons donc a traiter de littérature, et non de mythes." (Trousson, 1981, p. 20)

9 Trata-se de um posicionamento diametralmente oposto ao de Pierre Brunuel, que até mesmo nomeia o seu dicionário como Dicionário de Mitos Literários (2005).

10 "Il lui faut respecter la tradition qui pèse sur lui comme un poids dont il lui est impossible de se décharger sous peine de trahir ses propres intentions." (Trousson, 1981, p. 78)
} 
fundamentais, isto é, elementos essenciais da natureza humana. (Trousson, 1981, p. 122, tradução nossa) $)^{11}$

A retomada recorrente das tecelãs, portanto, pode ser considerada um tema pois perpassa a literatura ocidental, desde a antiguidade grega, passando pelo Fausto, de Goethe; o Ulisses, de Joyce; o Vulgo Grace, de Margareth Atwood; Uma aprendizagem ou o livro dos prazeres, de Clarice Lispector, entre outros exemplos. A tecelã é mobilizada enquanto tema porque evoca a figura do feminino por excelência, desdobrando-se ora nas tecelãs sensatas, herdeiras de Penélope e associadas aos modelos paradigmáticos da mulher exemplar, ora nas tecelãs sedutoras, herdeiras de Pandora, que constituirão uma linhagem de mulheres fatais.

Nesse sentido, um tipo temático específico, denominado longues durées (Guillén, 2005) interessará a nosso trabalho uma vez que o tema das tecelãs perpassa os séculos e apresenta recorrência notável, em funcionamento análogo a um símbolo inscrito dentro da sociedade: "O objeto ou a vivência se culturaliza e se tematiza a partir das estruturas de uma sociedade, por meio de seus canais de comunicação e destinados a seus leitores e ouvintes”. (Guillén, 1985, p. 267).

Para o crítico, "quem cita valoriza o repetido" (Guillén, 1985, p. 276), isto é, o escritor mantém a estrutura temática a fim de operar suas modificações e dessa forma recriar e reatualizar o texto do qual se nutre. Com esse procedimento, preserva aquele chão cultural que aprecia em destaque na história literária e, paralelamente, imprime os seus traços particulares, e de seu tempo, na tradição, reafirmando que a "pura repetição não existe, ou, que esse trabalho (intertextual) exerce uma função crítica sobre a forma." (Jenny, 1979, p. 44). Portanto, a literatura assume os seus próprios moldes e se recria a partir de tais referências.

Para Trousson (1981) essa reelaboração é prova cabal do domínio que um autor apresenta da tradição literária e sua habilidade de renovar a esfera literária a partir do rearranjo de suas referências:

Pode ser que seja indispensável ir mais longe e sustentar que o exame das modalidades de utilização de um tema permite colocar em evidência, de maneira mais adequada, a originalidade criativa de cada autor, precisamente porque o tema constitui um fio condutor, um ponto de referência, um primeiro termo ideal de comparação, que permite mensurar a

\footnotetext{
11 “Le thème est un fil conducteur, éternel à travers la durée, qui se charge, au long des siécles, de tout le butin artistique et philosophique amassé, sur sa route illimitée, par l'aventurier humain; c'est pourquoi il préserve et restitue à travers ses innombrables transmutations, quelques constantes, quelques préoccupations fondamentales, en un mot quelque chose de l'essentiel de la nature humaine." (Trousson, 1981, p. 122)
} 
potência de intervenção do autor na tradição que o circunda., ${ }^{12}$ (Trousson, 1981 , p. 55, tradução nossa)

Esse argumento nos aponta, para além de Guillén (1985), uma revalorização do citado e do autor que cita a partir da reelaboração temática. Ao se valer da tradição, os artistas demonstram que possuem vasto repertório cultural e sabem como instaurá-lo na narrativa. A partir dessa escolha, o autor consegue aplicar esse conhecimento e ao mesmo tempo inovar, o que comprova um movimento pendular, abarcando tanto o consolidado quanto o inovador.

\subsection{0 tear das Moiras: fios condutores de uma poética do mito}

"o mito, a magia e a busca de transcendência não estão enterrados no passado, mas fazem parte de todos os tempos e lugares habitados pelo homem." (Volobuef,2011, p. 7)

$\mathrm{Na}$ esteira das reflexões apresentadas, podemos considerar como composição literária primeva o mito oral, que foi sendo reapropriado e transformado pelas sucessivas tradições. Os mitos encantam. Fascinam por seus prismas, por seus múltiplos desfechos que não se contradizem. Os mitos permanecem. Venceram Guerras, de llíon à Fria. Édipo permanece de complexos à cegueira, Pandora ainda nos seduz com seus tantos dons e sua perigosa caixinha, Narciso nos mostra no espelho os perigos da arrogância. Ícaro nos promete ainda o sonho: entre aviões, paraquedas e foguetes. O minotauro insinua-se no nosso trato dúbio e labiríntico com a alteridade, com esse outro que sempre supomos mais alheio do que de fato é.

O mito das tecelãs, objeto de nossa pesquisa, desperta um fascínio singular, pois evoca paralelamente destino e criação, sedução e morte, configurando-se um terreno comum na memória cultural (Samoyault, 2008). Para melhor compreensão de sua retomada, devemos considerar alguns pressupostos teóricos acerca do discurso mítico, a fim de que se possa analisar com mais propriedade sua reatualização nos textos contemporâneos.

\footnotetext{
${ }^{12}$ Peut-être même est-il indispensable d'aller plus loin et de soutenir que l'examen des modalités d'utilisation d'un thème permet de mettre mieux en évidence la part d'originalité créatrice de chaque auteur, preecisement parce que le theme constitue un fil conducteur, un point de référence, un premier terme idéal de comparaison, permettant de mesurer la puissance d'intervention de l'auteur sur la tradition qui avait cours jusqu'à lui. (Trousson, 1981, p. 55)
} 
Em primeiro lugar, é preciso ressaltar que todo mito comporta em sua estrutura a ideia do eterno retorno; de modo que a narrativa mitológica é evocada de maneira cíclica e é indefinidamente reatualizada. Essa propriedade do discurso mítico garante sua constante assimilação pela tradição literária:

A matéria que ocupa o espírito no Mito tem, em si mesma, uma coerência, uma dignidade e uma autonomia (...) O gesto verbal do Mito é mais imperioso e mais restritivo - como o olho de uma agulha. Nesta forma que é o Mito, todos os elementos para os quais se oriente a disposição para o saber, todos os elementos do universo que sejam, ao mesmo tempo, constantes e múltiplos, são captados por um gesto verbal que os acolhe e os converte num evento único, onde eles encontram o sentido de sua multiplicidade e de sua constância. (Jolles, 1930, p. 100).

Dessa maneira, o mito não é uma totalidade acabada, mas suscita variações em seus detalhes. Podemos considerar, por exemplo, o nascimento de Afrodite, que em Hesíodo e Homero se apresenta de modos distintos, porém não-contraditórios. Lévi-Strauss (2008) chamará tal peculiaridade do mito de sistema bidimensional, uma vez que ele se configura simultaneamente como sincrônico e diacrônico, histórico e a-histórico. ${ }^{13} \mathrm{O}$ discurso mítico, portanto, comporta ambivalências e não se estrutura em uma organização binária, promovendo um outro modo de elo com o real.

Em contrapartida, apesar das variações, quantitativamente, a presença de mitos semelhantes em diversas sociedades e regiões aponta para uma recorrência da estrutura mítica, de forma que: "mitos, aparentemente arbitrários, se reproduzem com as mesmas características e, muitas vezes, os mesmos detalhes, em diversas regiões do mundo" (Lévi-Strauss, 2008, p.295).

Tal recorrência cultural é estudada por Gilbert Durand (2002) em sua obra Estruturas Antropológicas do Imaginário, na qual o teórico mapeia mitos semelhantes em diversas culturas, indicando que há aspectos do discurso mítico imbricados ao imaginário humano. Ao investigar as bases do pensamento mítico, Durand postula que o mito constitui:

um sistema dinâmico de símbolos, arquétipos e esquemas, sistema dinâmico, que sob o impulso de um esquema, tende a compor-se em narrativa. $\mathrm{O}$ mito já é um esboço de racionalização, dado que utiliza o fio do discurso, no qual os símbolos se resolvem em palavras e os arquétipos em ideias. (Durand, 2002, pp. $62-63$ ).

${ }^{13}$ Cf Lévi-Strauss. Antropologia Estrutural. São Paulo: Cosac Naify, 2008, pp. 298-301. 
O que nos interessa nessa obra é, particularmente, a exposição dos mitos e símbolos como constelações de imagens que permeiam o imaginário humano noção que se aproxima da visão intertextual e dialógica. Além disso, o teórico retoma o mito enquanto ambivalência, ou seja, os sentidos latentes na narrativa mitológica podem deslizar de acordo com dados sociais e históricos, concepção que nos permitirá refletir acerca da "reinserção" do mito das tecelãs no mundo moderno.

Ernst Cassirer (2013), já em 1924, postulara que a arte, o mito, a ciência e a linguagem partilham o estatuto de símbolo pois "cada uma delas gera e parteja seu próprio mundo significativo." (Cassirer, 2013, p. 22). O autor defende, assim, que tais saberes configuram-se como maneiras distintas de se apreender o real por meio do intelecto, mas que se condicionam mutuamente com relativa dependência e relativa independência.

$\mathrm{Na}$ esteira dos estudiosos da narrativa mitológica - Eliade, Durand e LéviStrauss, entre outros - situaremos o mito na esfera do sagrado e, portanto, no papel de "história verdadeira", já que o homem grego arcaico se vê enquanto fruto do mito e é ele o articulador de seu conhecimento do mundo. Ao se considerar o mito na qualidade de saber, é possível evocar Bourdieu (1998), pensador que o avalia no papel de universo simbólico - no patamar da língua, da arte e da ciência - e, logo, concebe-o não só como instrumento de conhecimento, mas também como produto coletivo e coletivamente apropriado. Com base nessas reflexões, o campo do mito pôde ser avaliado enquanto saber efetivo e dissociado dos estereótipos que o ligam à mentira e ao invencionismo.

Consoante a crítica, anterior à ciência, à filosofia e à religião, o mito é um discurso expressivo para o entendimento do ser humano e de sua relação com a cultura e com as narrativas, não há, assim, registros de sociedades em cuja composição cultural o mito não tenha sido relevante. Além disso, não podemos ignorar que o mito é o gênero fundador do imaginário humano, uma vez que não só constitui a primeira resposta da espécie perante o desconhecido, mas também funda a primeira forma de organização do pensamento:

A mitologia não só não se reduz à satisfação da curiosidade do homem primitivo, como a sua ênfase cognitiva está subordinada a uma orientação voltada para um enfoque integral do mundo no qual não se admitem os mínimos elementos do caótico, da desordem. A transformação do caos em cosmo constitui o sentido fundamental da mitologia, e o caos compreende desde o início um aspecto axiológico ético. (Mielietinski, 1987, p. 196) 
Nesse sentido, Cassirer (2013) destaca que o mito e a linguagem se assemelham em sua propriedade de configurar o mundo a partir do caos, atribuindo significado à massa amorfa da realidade e que, por isso, partilham a mesma forma de concepção mental. Paralelamente, Lévi-Strauss (2008) afirma que o sentido e a estrutura do mito só podem ser apreendidos por meio do verbo, uma vez que seus sentidos rituais não podem ser recuperados no mundo moderno; assim é preciso "estabelecer que o mito está ao mesmo tempo na linguagem e além dela." (LéviStrauss, 2008, p. 297), mas só pode ser acessado graças à palavra.

Cassirer (2013) afirma ainda que todas as formas simbólicas são derivadas do mito, enfatizando sobremaneira o forte vínculo da consciência mítico-religiosa e da consciência linguística. Para o filósofo, a palavra desempenha um papel central nas cosmogonias e, portanto, está imbricada com a criação ${ }^{14}$, visão partilhada por Jolles (1930):

Essa palavra "criação" leva-nos além do mito isolado. Mito é criação. Também aqui emprego a palavra no seu sentido mais profundo e recordo que a raiz germânica * skap tanto se encontra em schöpfen (vasar, tirar, encontrar) como em schaffen (criar) e conserva seu sentido no sufixo schaft. Já dissemos que o mito é o lugar onde o objeto se cria a partir de uma pergunta e de uma resposta; por outras palavras: o mito é o lugar onde, a partir da sua natureza profunda, um objeto se converte em criação (Schöpfung). (Jolles, 1930, pp. 90, 91)

Aqui, palavra e criação são indissociáveis: as tecelãs, cuja trajetória acompanharemos, caracterizam-se, sobretudo, por seu elo com a criação, e seu tear gera não só produtos têxteis a partir de elementos da natureza, mas também tecidos metafóricos entremeados pela palavra e engendrados pela criatividade.

Nessa perspectiva, Cassirer (2013) argumenta que a propriedade comum entre mito e linguagem é justamente o pensamento metafórico, que levou o homem a criar novas narrativas e formas verbais que pudessem expressar, por meio da comparação e da representação, as necessidades cada vez mais complexas do espírito humano. ${ }^{15} \mathrm{~A}$ metáfora, portanto, é considerada como um procedimento simbólico complexo que faz o discurso mítico ecoar na literatura. Mielietinski (1987), refletindo sobre Cassirer, enfatiza que "o conflito entre significado e imagem faz parte da essência da própria expressão simbólica; a forma do pensamento mitológico transforma toda a realidade em metáfora." (Mielietinski, 1987, pp. 56, 57)

\footnotetext{
${ }^{14} \mathrm{Cf}$ Ernst Cassirer. Linguagem e Mito. São Paulo: Perspectiva, 2013, pp. 63,64.

${ }^{15} \mathrm{Cf}$ Ernst Cassirer. Linguagem e Mito. São Paulo: Perspectiva, 2013, pp. 102-105.
} 
Logo, a metáfora configura-se como um elo privilegiado com a estrutura mítica. Ao investigarmos em que medida $\mathrm{o}$ ato de tecer corresponde, metaforicamente, ao narrar devido a um deslizamento mítico, estaremos resgatando tais articulações entre discurso mítico, metáfora, palavra poética e criação. Voltaremos a esse entrelaçamento da escritura e da tessitura para compreender de que modo o mito e a situação social da tecelagem permitiram sua associação com a narrativa.

Um outro aspecto relevante da metáfora é que, segundo Ricoeur (1995), a figura resgata em seu funcionamento redes associativas, que evocam a estrutura da intertextualidade e das constelações míticas, na medida em que as três instâncias produzem feixes de relações em um desenho de teia:

O funcionamento metafórico seria completamente inadequado enquanto modo de expressar a diferente temporalidade dos símbolos, o que poderíamos chamar a sua insistência, se as metáforas não se resgatassem da total evanescência, por um conjunto total de intersignificações. Com efeito, uma metáfora exige outra e cada uma permanece viva ao conservar o seu poder de evocar toda a rede. (Ricoeur, 1995, p. 111)

Nessa direção, a metáfora parece herdar do mito tanto a propriedade da repetição e da evocação de sentidos latentes, quanto o encadeamento com outras estruturas simbólicas. Tal predicado é encarado por Ricoeur (1995) como uma correspondência verbal do símbolo, isto é, a metáfora seria o símbolo feito de palavras:

Há mais na metáfora do que no símbolo. No sentido de que ela traz à linguagem a semântica implícita do símbolo. O que permanece confuso no símbolo - a assemelhação de uma coisa a outra e de nós às coisas; a infinda correspondência entre os elementos é clarificada na tensão da enunciação metafórica. Mas há mais no símbolo do que na metáfora. A metáfora é o procedimento linguístico (...) dentro do qual se deposita o poder simbólico. (...) As metáforas são precisamente a superfície linguística dos símbolos e devem o seu poder de relacionar à superfície semântica bidimensional do símbolo. (Ricoeur, 1995, p. 115)

Complementando tal raciocínio, evocamos a afirmativa de Jolles (1930): "o símbolo não é, no meu entender, imagem, mas objeto dotado de uma carga efetiva de Mito e detentor autônomo do poder do Mito." (Jolles, 1930, p. 108). Nesse sentido, se estabelecermos um paralelo entre os postulados de Jolles e Ricoeur, podemos afirmar que a metáfora é o objeto linguístico que detém uma carga efetiva de Mito, uma vez que seria o correspondente verbal do símbolo.

Assim, a metáfora é um dos componentes centrais da estrutura do mito. A compreensão de tais estruturas será vital para que se possam notar os ecos míticos 
na fatura das obras literárias da modernidade. Lévi-Strauss (2008) também destaca a importância do sistema temporal do mito enquanto marca distintiva. A temporalidade mítica ancora-se, paralelamente, em um "há muito tempo" e configura uma estrutura permanente em que passado, presente e futuro coincidem, resultando daí uma atmosfera atemporal.

Além disso, a repetição é central na estrutura do mito, caracterizando-se como o traço que permite torná-la manifesta, ainda que as camadas da repetição nunca sejam rigorosamente idênticas. O antropólogo postula que as unidades constitutivas do mito, por meio das quais é possível reconhecer suas especificidades, são os mitemas, que só adquirem função significante quando postos em relação. Durand (1963) resgata essa definição afirmando que "os mitemas são os pontos fortes, repetitivos da narrativa." (Durand, 1963, p. 29). A redundância, portanto, é o elemento significativo que permite a análise da estrutura e o reconhecimento dos mitemas.

Outro traço fundamental destacado por Jolles (1930) é a estruturação do mito enquanto resposta a uma interrogação e, logo, sua estrutura é assertiva: "Os períodos são redigidos de maneira nobremente afirmativa e, ouso dizer, apaziguadora, onde se surpreende como que o eco de um diálogo" (Jolles, 1930, p. 87). Em sua fatura, o mito instaura um universo narrativo afirmativo e formulador de certezas.

Desse modo, a atmosfera atemporal, a repetição, a metáfora e a formulação assertiva serão investigadas na estrutura das narrativas analisadas para reafirmar seu parentesco com as narrativas primordiais na temática/fatura. É evidente que ao passarmos do mito, gênero oral por excelência, para o conto moderno esses aspectos temáticos-formais sofrerão deslocamentos e tais desvios constituem o interesse dessa pesquisa comparativa.

A permanência de narrativas míticas na atualidade pode ser justificada por uma série de razões relacionadas à sua natureza, porém vale também destacar a sua habilidade de abordar temas e conflitos inerentes à humanidade. Deve-se a sobrevivência dos mitos às obras literárias, revelando-se aí o "triunfo da literatura" (Eliade, 2002, p. 138) já que ela se configura, entre outros aspectos, por plasmar dados culturais básicos para a humanidade, uma vez que muitos mitos sobrevivem nos textos e não em seu contexto mítico-religioso. 
Desse modo, além de estarem registrados de maneira próxima à primordial (à qual jamais teremos acesso) nos poemas gregos, também verificamos a sobrevivência do mito das tecelãs em suas retomadas ao longo da tradição literária. O mito condensa, portanto, um princípio da intertextualidade: "levar, para além da atualização de uma referência, o movimento de sua continuação na memória humana." (Samoyault, 2008, p. 117).

A assimilação de mitos é bastante profícua no Ocidente, em diversas esferas discursivas, como a pintura, a escultura, a novela, o cinema, a música e, sobretudo, a tradição literária. O mito exerce certo fascínio sobre o homem e constantemente voltamos a ele: "(o mito) não cessa de condensar seu sentido no desdobramento de suas versões sucessivas, assegurando mais, além das variações de detalhe, a fixação de seus traços permanentes." (Samoyault, 2008, p. 115). Em todas essas esferas discursivas o mito retorna reelaborado, muitas vezes fundido a elementos modernos, pela atualização dos conflitos, do cenário, do figurino da abordagem, porém mantém traços que permitem o seu reconhecimento enquanto narrativa primordial.

Samoyault (2008) considera a análise mitológica "um estudo intertextual completo na medida em que o interesse consiste em situar circulações de sentido, transportes de temas e figuras." (Samoyault, 2008, p. 118). Dessa forma, os mitos constituem rico substrato cultural a que os artistas, em geral, recorrem na produção de suas obras, assimilando certos traços e operando transformações no pormenor, processo que reatualiza o mito e o torna um meio de elucidar questões do homem contemporâneo.

Esse liame entre mito e literatura é central para que se compreenda a permanência mítica em produções contemporâneas: "Todos os homens podem verse refletidos por via do mito, do símbolo, do nó apertado de significações que ata a obra literária." (Guillén, 2006, p. 56). A estrutura mítica recupera ecos primordiais e aponta para o encanto. A literatura já não é mais o mito, mas em seu valor estético recupera alguns traços sagrados de alento e catarse, desempenhados pelas narrativas primordiais.

E ainda, consoante Durand (1983), a imagem literária desempenhou um papel privilegiado na transmissão do imaginário mítico: "A imagem literária tem um estatuto um pouco especial se comparada com outras linguagens ou com outros modos de expressão (...) O discurso literário está muito próximo do mito, e isto os maiores 
antropólogos viram-no (Mircea Eliade, por exemplo, ou Claude Lévi-Strauss)." (Durand, 1983, pp. 26, 27).

O mito estrutura-se por meio da narratividade, porém mito e literatura pertencem a esferas discursivas distintas. Ruthven (2010) revisita as teorias do mito para se indagar que semelhanças e diferenças relacionam o fenômeno mítico ao literário. Para Herbert Read (1938), revisitado por Ruthven (2010), a diferença central entre os campos é que o mito se identifica com a imagem e por isso pode ser expresso por qualquer estrutura verbal, enquanto no fenômeno literário o trabalho com a linguagem é central e configura sua especificidade. Lévi-Strauss recobra essa ideia em 1958: "O mito poderia ser definido como modo do discurso em que o valor da fórmula traduttore, traditore tende a praticamente zero. (...) sua substância não se encontra nem no estilo, nem no modo da narração, nem na sintaxe, mas na história que nele é contada." (Lévi-Strauss, 2008, p. 299)

Assim, no mito o conteúdo é destacado, sem liame com a forma, enquanto na literatura forma e conteúdo são indissociáveis. Nesse sentido, os folcloristas afirmam que no século XXI não deparamos mais com mitos, mas com a literatura que os reelabora, já que o mito associa narrativa e ritual e é independente da forma: "No caso do mito, a sua conversão em poesia acontece quando a dominante deixa de ser mágico-religiosa para tornar-se estética." (Loureiro, 2006, p. 182). Portanto, é no momento em que perde a sua função prática no funcionamento social que o mito converte-se em narrativa.

Em contrapartida, consoante Mielietinski, a literatura guarda forte herança mítica, pois é do mito que ela se origina: “ A forma artística herdou do mito o modo concreto-sensorial de generalização e o próprio sincretismo. Em seu processo de evolução, a literatura utilizou os mitos tradicionais com fins artísticos durante muito tempo." (Mielietinski, 1987, p. 01). Os mecanismos literários e mitológicos, conforme assinalado desde Lévi-Strauss, estão fortemente atados, uma vez que acentuam as qualidades secundárias: detalhes, índices, metáforas, metonímias etc.

Em suma, a literatura traz à tona os vínculos entre palavra poética e mito e condensa nossa possibilidade de experiência estética das estruturas arcaicas. A literatura revela-se o espelho em que o ser humano pode mirar a si mesmo, de maneira sincrônica e diacrônica, e vivenciar intensamente o encantamento. 


\title{
1.3 Tramas do feminino: tecelãs do fuso e da fala
}

\author{
A história humana começou com os mitos; \\ e dentre todos, aquele que nos prende \\ ainda à dinâmica imaginária mais fecunda \\ é o mito das fiandeiras". (Brunel, 2005, p. 370)
}

Tentamos percorrer as linhas centrais suscitadas pelo estudo do mito, priorizando aquelas que permitirão uma análise mais rica dos textos literários. Enfatizamos o caráter parcial de tal exposição, já que, segundo Eliade (2002) é impossível encontrar uma definição assertiva de mito, que contemple todas as culturas.

Nossa opção pela figura das tecelãs, no mundo grego, parece justificada por uma insistência de tal escopo mítico nas formulações do imaginário. A tessitura e a tecelagem associam-se ao próprio fio da existência e recuperam a noção de uma instância feminina criadora e trans-formadora:

E nessa linha de astúcias, e de fios, e de tramas, há toda uma tradição, na Grécia, de mulheres fiandeiras. Penso em Pandora (a primeira mulher), tecelã, que aprendeu a arte das fiandeiras com a deusa Atena, cujo epíteto é exatamente Atena Penitis, a "tecelã". Mas há também Aracne, que desafia a deusa Atena na arte da tapeçaria e acaba transformada em aranha; e Ariadne, que fornece a Teseu o fio com que ele enfrenta o labirinto. E há as Parcas, que tecem a trama dos destinos humanos. Todas, mulheres. (Meneses, 2002, p. 75)

Pretendemos investigar o mito das tecelãs sob duas perspectivas centrais: como metáfora para o narrar e como instaurador de um discurso feminino em substituição a seu silenciamento histórico. A reelaboração de um mito arcaico, implica, necessariamente, que valores e forma tenham sofrido transformações radicais ao serem ancorados na história e na sociedade contemporâneas.

Nesse sentido, a retomada desse mito pode instaurar tanto uma oposição a alguns excessos da modernidade, chamando-nos de volta para a criação artística, quanto marcar uma contraposição aos valores patriarcais que antes representava, ao delimitar um locus de autonomia feminina.

Para tanto, é imperativo considerar o embate entre permanências e rupturas que se dá no bojo das relações intertextuais. E a figura da mulher-tecelã-narradora traz à cena tais tensões, já que o mito não retorna fiel aos seus valores tradicionais. Enquanto na Antiguidade a tecelã representava o lugar de silenciamento da mulher, confinada ao óikos, as neo-tecelãs que analisamos resgatam a tecelagem como 
espaço de produção de discurso e resistência, subvertendo no tear os valores patriarcais que outrora os fios sustentavam.

As tramas dos contos selecionados embrenham-se na tessitura mítica e ora evocam as parcas, ora Penélope, sua manta e sua espera; ora Ariadne e seu fio redentor - seja por aproximação seja por distanciamento. Em alguns textos do corpus, a relação com o imaginário da tecelã é mais evidente, como em "A Moça Tecelã" (2009), no qual a protagonista de fato tece em seu tear mágico e, dessa forma, recria a realidade a sua volta. O seu elo com a criação e com a interferência no destino a ligará às Moiras, enquanto a recorrência do tecer/destecer a aproximará de Penélope. Já em "Colheita" (1997), tal analogia não é explícita, pois a tessitura encontra-se latente no cuidado doméstico, na elaboração culinária e na tomada do discurso pela personagem feminina. Relacionamos a mulher de "Colheita" (1997) com as tecelãs, mais especificamente com a Penélope homérica devido a uma série de características que as colocam em diálogo, por exemplo, a espera, a presença de pretendentes, o marido viajante, entre outras.

Em "Penélope" (1998), de Dalton Trevisan, por exemplo, deparamos com o modelo avesso de Penélope: uma anti-penélope, apequenada no mundo urbano, que recebe cartas adúlteras e subverte o sentido do modelo de fidelidade expresso em Homero.

Já em "Desenredo" (2001) não temos uma mulher que tece e sim o protagonista, Jó Joaquim, que desmancha à maneira de Penélope a manta-enredo que fora bordada pela traição de Livíria e tece uma história nova, em que a traição é desconstruída. Além de evocar a reescrita de um destino, Jó Joaquim invoca a criação literária, uma vez que os componentes da narrativa são pilares do conto, e ainda trabalha com o imaginário da fidelidade, elo que o aproxima da Odisseia homérica, de modo que passamos a analisar uma personagem masculina no papel de Penélope. Livíria é ainda, metaforicamente, tecelã de engodos e astuciosas porque discretas - traições, resgatando ainda o imaginário das tecelãs fatais descendentes de Pandora e Helena, figuras míticas diametralmente opostas à Penélope homérica.

Assim, os textos escolhidos reelaboram o imaginário das tecelãs e mostram sua permanência em contos contemporâneos, ainda que revestidas de novos valores e contestações. A tecelã será criadora e tecer será uma resistência simbólica ao silêncio imposto à mulher em uma sociedade patriarcal. 
Para melhor compreensão dos deslocamentos sofridos pelo mito das tecelãs, na sua assimilação pelos contos brasileiros da modernidade, faz-se necessário mapear ao menos quatro instâncias que fornecerão os subsídios analíticos necessários para um estudo aprofundado: o mito das tecelãs em seu contexto tradicional; a história social da tecelagem e das mulheres gregas; o deslizamento de sentido entre tecer e narrar e certos aspectos do contexto brasileiro que permitiram sua articulação com o mito das tecelãs tanto como metáfora para o narrar, quanto como espaço discursivo feminino.

A linhagem das tecelãs nos enreda e encanta. Trata-se de uma genealogia de mulheres que fazem girar o fuso da vida e da sedução. A maioria delas pertence a enredos míticos distintos, mas, paralelamente, unem-se por um fio invisível. Não é coincidência que nos grandes dicionários de mitos literários e de mitos femininos elas apareçam unidas, agrupadas sob os vocábulos fiandeiras ou tecelãs.

Nosso trabalho aborda as tecelãs gregas, porém vale ressaltar que a ligação do tear com a vida e a criação também se encontra presente em outras latitudes. No Dictionaire des mythes féminins, Sylvie Ballestra-Puech (2002) afirma que diversas divindades fiandeiras são encontradas no domínio indo-europeu: as Moiras gregas, as Parcas romanas, as Nornas e as Valquírias escandinavas. Segundo Marie-Louise von Franz (2003), tanto para o Rigveda (texto religioso hindu) quanto para o présocrático Ferekydes, a tecelagem está ligada à cosmogênese, sendo a deusa da natureza o tear no qual Deus lança o seu fuso para tecer o mundo ${ }^{16}$. No Dicionário de Símbolos de Chevalier ${ }^{17}$ (1994) , há um mapeamento do significado da tecelagem em diversas culturas, ainda que o autor não contextualize nem singularize em todos os momentos a quais tradições se refere, pode-se perceber que a mesma atmosfera sensível percorre a figura do tear em diversas concepções. ${ }^{18}$

\footnotetext{
${ }^{16}$ Cf. Marie-Louise von Franz. Mitos de Criação. São Paulo: Paulus, 2003, p. 129.

${ }^{17}$ CHEVALIER, J. Dicionário de Símbolos. Paris: Laffont S.A, 1994.

${ }^{18} \mathrm{O}$ tear significa a estrutura e o movimento do universo. (...) O trabalho de tecelagem é um trabalho de criação, um parto. Quando o tecido está pronto, o tecelão corta os fios que o prendem ao tear e, ao fazê-lo, pronuncia a fórmula de benção que diz a parteira ao cortar o cordão umbilical do recém-nascido. Tudo se passa como se a tecelagem traduzisse em linguagem simples uma anatomia misteriosa do homem. Tecido, fio, tear, instrumentos que servem para fiar ou tecer (fuso, roca) são todos eles símbolos do destino. Servem para designar tudo o que rege ou intervém no nosso destino. A lua tece os destinos; a aranha tecendo a sua teia é a imagem das forças que tecem nossos destinos. As Moiras são fiandeiras, atam o destino, são divindades lunares. Tecer é criar novas formas. Inúmeras deusas, deusas importantes, trazem nas mãos fusos e rocas (...) Dominam assim o tempo, a duração dos homens, e envolvem, por vezes o aspecto duro e impiedoso da necessidade, essa lei que rege a contínua e universal mudança.(...) Fiandeiras e tecelãs abrem e fecham ciclos individuais, históricos e cósmicos. (Chevalier, 1994, p. 872 )
} 
Sylvie Ballestra-Puech (2002) cita ainda uma carta de Victor Hugo na qual o autor afirma que, em toda a mitologia, a arte de tecer aparece como invenção feminina. Para a autora, a tecelagem parece ter sido a única técnica inventada e quase exclusivamente exercida por mulheres e por isso é capaz de convocar para a reflexão acerca do poder criativo feminino: "Uma mulher é uma experiência e uma energia feminina que tece, que é tecida, que é desfeita e que se movimenta." (Koltuv, 1990, p. 113)

As primeiras tecelãs a serem evocadas na cultura grega são as Moiras, divindades associadas à vida e à morte, sobre as quais nem mesmo Zeus possui algum poder. Segundo o dicionário mítico-etimológico ${ }^{19}$ (2014), o vocábulo grego Moîra significa lote, parte que cabe a cada um e, por extensão, destino. Referências ao mito das Moiras ocorrem na llíada (IV 517; V 83; XII 116) e na Odisseia (III, 269 e XI, 292). No princípio, a Moira era apenas uma e pairava sobre os deuses sem atributos antropomorfos, porém após o período homérico a figura desdobrou-se em três irmãs: Cloto, que fia a vida, Láquesis, a sorteadora que enrola o fio da vida e Átropos, cujo nome significa "não voltar atrás" e corta o fio da vida. Ainda no poema hesiódico se mencionará a figura das Moiras - Cloto será a fiandeira, Láquesis a distribuidora e Átropos, a inflexível: "Noite pariu (...) Fiandeira, Distributriz e Inflexível que aos mortais/ tão logo nascidos dão os haveres de bem e de mal,/ elas perseguem transgressões de homens e Deuses/ e jamais repousam as Deusas da terrível cólera/ Até que deem com o olho maligno naquele que erra. (Hesíodo, 1995, p.117, vv. 218-222)

Devido a esse mito, a tecelagem foi definitivamente articulada à criação, à vida, ao destino e à morte: "As Moiras fundam o mundo feminino, na medida em que ele é representação da periodicidade, da renovação, da transformação, da ruptura e do nascimento." (Brunel, 2005, p. 375)

Conforme assinalado pelos estudos clássicos, a Teogonia e os poemas homéricos são relativamente contemporâneos. É impossível precisar a data exata de circulação de tais poemas, ainda mais porque a épica arcaica pertencia ao mundo da oralidade e só muito posteriormente foi registrada por escrito. O poema de Hesíodo, como o próprio título revela, narra a origem dos deuses. Interessa aqui, sobretudo, a existência de duas potências femininas iniciais: Gaia e Noite,

${ }^{19}$ BRANDÃO, Junito de Souza. Dicionário mítico-etimológico. Petrópolis: Editora Vozes, 2014. 
consideradas as mães do universo. É notável que se postule, desde o princípio do cosmos, tal ambivalência do feminino: de um lado Gaia, a mãe benfazeja que se unirá a Urano, e de outro a Noite, que dá à luz de modo solitário e em cuja figura "esboça-se a ideia de uma feminilidade fechada sobre si própria e desde o início separada. Ameaçadora como nenhuma outra." (Duby e Perrot, 1993, p. 63)

Daí, podemos deduzir que, já na Teogonia, estava delineado o germe da duplicidade feminina delimitada pela mulher fatal e pela mulher idealizada no papel de mãe ou donzela. Este trabalho enfoca as mulheres sensatas, herdeiras de Penélope, e mulheres fatais, herdeiras de Pandora, devido à maior repercussão de tais grupos no imaginário ocidental. No entanto, tal linhagem esboça-se desde as mulheres-Gaia que contemplariam Penélope, Hécuba, Andrômaca e as mulheresnoite, a saber, Pandora, Helena, Clitemnestra, Circe e Calipso.

Ainda entre as divindades femininas, pode-se destacar a figura central das Musas, senhoras da inspiração poética. As nove musas, filhas da memórias, são guardiãs das artes centrais da cultura grega: a poesia épica (Calíope), a poesia lírica (Érato), a música (Euterpe), a dança (Terpsícore), a comédia (Talia), a tragédia (Melpômene), a canção sacra (Polímnia), a astronomia (Urânia) e a história (Clio). ${ }^{20}$ Segundo os estudos de Anne Bergren (2008), a proximidade entre o discurso poético e a feminilidade está centrada na figura das musas pois delas advém a inspiração poética. As musas detêm poder sobre a verdade e sobre a ficção; os poetas épicos pedem a elas a inspiração para narrar fatos não vivenciados por eles, mas que se tornam acessíveis pelo dom das filhas de Mnêmosine : "As musas podem falar tanto a verdade quanto ficções que imitam os fatos, sem nenhuma restrição. Nenhum conhecimento ou poder expressivo poderia ser mais completo" (Bergren, 2008, p. 14, tradução nossa) ${ }^{21}$

$\mathrm{Na}$ esteira dessas reflexões, constata-se que a duplicidade do discurso das Musas espelha as duas maneiras de se encarar o discurso feminino ao longo da tradição grega: como voz da verdade e da profecia - as Moiras - ou como voz portadora de ardis - Circe e Calipso (Bergren, 2008). Nesse sentido, podemos pensar em duas linhagens de mulheres na literatura grega: As herdeiras de Penélope e as herdeiras de Pandora/Helena.

\footnotetext{
${ }^{20}$ BRANDÃO, Junito de Souza. Dicionário mítico-etimológico. Petrópolis: Editora Vozes, 2014, p. 438.

21 "the muses can speak both the truth and fictions that imitate fact, with no constraint. No knowledge or power of utterance could be more complete.." (Bergren, 2008, p. 14)
} 
Também na esfera divina destaca-se a Deusa Métis, que legará às mulheres a tecelagem como a arte feminina por meio de sua filha Atena. Détienne (2008) narra que Métis era a primeira esposa de Zeus, cujos poderes ameaçavam a soberania do deus. Havia uma profecia de que ela geraria dois filhos, uma menina e um menino, cujo destino era destronar Zeus repetindo o que ele fizera com Crono. Assim, depois de engravidar de Atena, Métis foi engolida por Zeus que se apropriou de sua inteligência astuciosa. Essa forma muito particular de inteligência múltipla e diversa será igualmente característica do casal Ulisses e Penélope na Odisseia. A métis é responsável por: "Múltiplas habilidades úteis à vida, domínio do artesão em seu ofício, uso de filtros e de ervas, astúcias de guerra, enganos, fingimentos, desembaraços de todos os gêneros." (Détienne, 2008, p. 17).

No episódio, Bergrenn (2008) reconhece uma apropriação dos poderes femininos pelos homens que será recorrente na literatura grega ${ }^{22}$. Uma vez que suas reflexões centram-se nas relações entre tessitura, discurso e mulher na Grécia arcaica, a autora relaciona esse mito ao silenciamento feminino, "a métis está relacionada ao poder discursivo atribuído às mulheres e ao porquê os homens precisam possuí-lo." (Bergren, 2008, p. 18, tradução nossa). ${ }^{23}$ Para ela, o medo do homem grego diante do discurso feminino leva-o a silenciá-la, uma vez que a fala encantatória da mulher o desestabiliza e não permite a distinção entre verdade e artifício.

Outra tecelã divina que merece destaque é Palas Atenas. A deusa da sabedoria herda de sua mãe o vínculo com a tecelagem, sua atuação é múltipla, mas, para nós, interessará seu domínio sobre o bordado e a métis, que fará de Atenas a protetora do casal Ulisses e Penélope. Enquanto "obreira" 24 , ela guia as artes da tecelagem, da fiação e do bordado. O autor assinala, ainda, que para dar exemplo às mulheres, a Deusa confeccionava e bordava sua própria túnica.

Na esfera humana, a mais célebre tecelã é certamente Penélope. Esposa de Ulisses, Penélope torna-se um símbolo da fidelidade pois espera durante duas

\footnotetext{
22 "appropriation by the male of what he attributes to the female persists throughout Greek literature (...) he take on her powers, and then to proceed as if they had always been his own." (Bergren, 2008, p. 15) < apropriação pelo homem daquilo que ele considera atributo feminino persiste durante a literatura grega (..) Ele rouba os poderes da mulher e prossegue como se sempre houvessem sido dele.> (tradução nossa) ${ }_{23}$ "mêtis is related to the power of speech ascribed to the female and why the male needs to posses it" (Bergren, 2008, p. 18)

${ }^{24}$ BRANDÃO, Junito de Souza. Dicionário mítico-etimológico. Petrópolis: Editora Vozes, 2014, p. 91
} 
décadas o retorno do esposo. O episódio central, na narrativa de Penélope, é o ardil do tear. Após muitos anos de ausência de Ulisses a nobreza de Ítaca começa a exigir que a rainha se case novamente. Diversos pretendentes são enviados à casa de Ulisses, pressionando a rainha e destruindo o patrimônio de seu marido. A rainha, para se manter fiel ao amado, vale-se de um engodo: só se casaria após terminar de tecer a mortalha do sogro Laerte. Contudo, ela tecia durante o dia e desmanchava o trabalho à noite, conseguindo adiar por três anos o suposto casamento, tempo suficiente para o retorno de Ulisses.Segundo Mossé (1983), a situação de Penélope, na Odisseia, é muito particular devido à ausência de informações sobre a sorte de Ulisses. Caso o esposo estivesse morto, ela naturalmente retornaria à casa de seu pai, que lhe arranjaria um novo casamento.

Porém, como a morte de Ulisses não é evidente, instaura-se uma suspensão. Essa ambiguidade contribui para o entendimento da atitude dos pretendentes, porém não a clarifica completamente. Ao cortejarem com insistência a rainha, buscavam, na verdade, uma união que tornaria um deles o chefe de Ítaca. A postura de Penélope, portanto, é duplamente virtuosa: de um lado, enquanto esposa, ela se mantém fiel ao marido e, de outro, enquanto rainha e administradora do óikos, não permite que outro homem se apodere do patrimônio de Ulisses.

O mito de Penélope será o do vínculo mais estreito com a tecelagem nas sucessivas atualizações dos mitos das tecelãs. Em seu nome, já está o germe desse elo: "Penélope: aquela que tece. Seu próprio nome (grego: Penelopeia) revela sua vocação: do grego pene, fio de tecelagem e, por extensão, trama, tecido (daí o nosso pano, do latim pannus)" (Meneses, 2002, p. 76). No ardil do tear, fica evidente a ação da métis de Penélope: "a métis é uma potência de astúcia e engano. Ela age por disfarce." (Détienne, 2008, p. 29).

Em contrapartida, para ser fiel a Ulisses, Penélope recorre ao engodo e, assim, distancia-se do horizonte de expectativa da mulher idealizada, desvelando a ambiguidade feminina: "isso traz à tona o dilema dos pretendentes - e de qualquer homem - confrontados com a mimese feminina: como distinguir verdade e aparência no discurso feminino?."25 (Bergren, 2008, p. 4, tradução nossa). A duplicidade e a ambiguidade femininas comparecem até na figura da sensata Penélope - a mais fiel

25 "it recalls the dilemma of the suitors - or any man - confronted with female's mimesis: how to distinguish the female's true speech from it likeness" (Bergren, 2008, p. 4) 
das mulheres - mesmo ali há um quê de fatalidade, uma dose de olhos de cigana oblíqua e dissimulada.

Outra mulher que muda o destino por meio do fio é Ariadne ${ }^{26}$ e seu novelo que ajuda a desmanchar labirintos. Ela conduz a trajetória de Teseu para fora do labirinto do Minotauro. Para o herói, o simples aniquilamento da besta era inútil, pois a morte o encontraria devido à impossibilidade de escapar dos muros de Dédalo. No entanto, a mulher o conduz em segurança para fora da muralha. Nesse sentido, é Ariadne a verdadeira heroína do mito grego, ela e os fios com que tece o destino de ambos. Para além da vitória contra a morte, na figura de Ariadne está presente a potencialidade redentora do fio: a linha pode guiar e desfazer obstáculos intransponíveis.

Há também a emblemática tecedeira Aracne (As Metamorfoses, Ovídio VI 5145) que confia tanto em sua habilidade no tear que decide desafiar Atena num concurso da arte. Em seu tapete Aracne imprime todas as atrocidades cometidas pelos deuses contra as mulheres. Seu trabalho é tão perfeito que acaba vencendo o de Atena, que transforma a moça em aranha como castigo por ter desafiado os deuses. A tessitura de Aracne é uma narrativa capaz de expressar uma denúncia, de modo que, mais uma vez, podemos notar a forte aproximação entre narração e tecelagem.

O mito de Filomela ou Filomena (As Metamorfoses, Ovídio VI 576-579), nessa direção, muito se aproxima ao de Aracne. Filomela era a irmã caçula de uma rainha que acabara de se casar. Quando ela e a irmã se mudam de palácio, o cunhado de Filomela a estupra e corta a sua língua para que ela não o denuncie. A moça, entretanto, costura um tapete em que delata a ação vil do cunhado. Por meio da tecelagem ela consegue fazer justiça, mostrando o poder expressivo de uma teia silenciosa.

Outra mulher essencial no universo mítico homérico é Helena. A mais bela das mulheres é igualmente uma tecelã, ainda que poucas vezes essa sua habilidade seja destacada. No canto III da llíada podemos observar que Helena tece um microcosmo do poema, ao confeccionar uma tapeçaria que narra a luta de Troia . Ela demonstra ter consciência de que, graças a seu registro, a memória da Guerra

\footnotetext{
${ }^{26}$ BRANDÃO, Junito de Souza. Dicionário mítico-etimológico. Petrópolis: Editora Vozes, 2014.
} 
de Ílion ficará preservada para a posterioridade ${ }^{27}$. Já no canto IV da Odisseia, Helena aparece efetivamente no papel de narradora ao contar para Telêmaco e Menelau histórias da Guerra de Troia. Logo, ela aparece paralelamente como produto e produtora do discurso poético.

Nesse episódio da Odisseia, ela recupera efetivamente seu lugar de rainha pois toma a palavra: "Fato ainda mais memorável é que Helena não hesita em tomar a palavra, e é ela que reconhece que Telêmaco é filho de Ulisses ${ }^{28}$." (Mossé, 1983, p. 27). A segurança de Helena para falar em público atesta que, apesar dos anos vividos em Troia, ao retornar para a casa de Menelau, ela reassume plenamente as suas funções de esposa e rainha. Contudo, essa é uma postura possível apenas na literatura, às mulheres gregas empíricas não era dada a possiblidade de tomar a palavra em público como o fazem as heroínas de Homero.

Helena é ainda uma tecelã de ardis sedutores, para além da beleza ímpar, ela é portadora da palavra poética encantatória ${ }^{29}$ : "A verdadeira magia da palavra consiste em ser, como a "canção bordada", uma excepcional sinestesia das artes plásticas e verbais , uma "palavra esculpida" que "persuade" como Pandora." 30. (Bergren, 2008, p. 28, tradução nossa) Por meio da sedução, Helena faz-se herdeira de Pandora, a primeira mulher esculpida pelos deuses para tornar-se a perdição do homem. Em Pandora, concentra-se a duplicidade do feminino, coexistindo beleza e artifício na mesma proporção.

Podemos notar que as imagens construídas pelos gregos na literatura podem também desvelar a posição da mulher na sociedade. Segundo Mossé (1983), a figura de Pandora é central para essa compreensão. O homem grego, a partir do mito de Pandora, encara a mulher como o mal. Contudo, um mal encantador, equipado de todas as estratégias de sedução e artifícios dos quais o homem não consegue escapar:

$\mathrm{Na}$ elaboração do mito de Pandora encontram-se, na verdade, os pares de oposições que estruturam o pensamento do homem grego. No lado do homem a cultura, a civilização, a guerra, a política, a razão, a luz;

\footnotetext{
${ }^{27}$ Cf. Bergren, Anne. Weaving Truth, 2008, p. 02.

28 “Fait plus remarquable encore, Hélène n'hesite pas à prendre la parole, et c'est elle qui reconnâit en Télémaque le fils d'Ulysses" (tradução nossa)

${ }^{29}$ Cf. Bergren, Anne. Weaving Truth, 2008, p. 02.

30 "The deceptive wizardry of the word consists in being, like the "woven song", an uncanny synesthesia of plastic and verbal artforms, a "sculpted word" that "persuades" like Pandora." (Bergren, 2008, p. 28)
} 
No lado da mulher a natureza, a selvageria, os trabalhos domésticos, a desmedida, a noite. (Mossé, 1983, p. 98, tradução nossa) ${ }^{31}$

Outras duas mulheres fatais, centrais da tradição homérica, são Circe e Calipso. As duas ocupam uma posição intermediária entre o universo humano e o divino. Circe e Calipso, como Helena, cantam e tecem, porém se aproximam ainda mais da palavra enquanto magia, porque efetivamente preparam filtros e poções que têm efeito de transformar o real. Circe, deusa e feiticeira, transforma os homens que visitam sua casa em animais, além de deter o poder de sedução do canto e da tecelagem: "Circe a cantar com voz melodiosa/ enquanto se dedicava à trama imperiosa da sua tecelagem,/ sutil, graciosa e brilhante como são as tapeçarias das deusas." (Homero, 2003, p. 168 vv. 221-223).

Calipso - "a oculta", "a que esconde"32 - consegue com sua magia retardar a partida de Ulisses por sete anos. A ninfa também possui os dons do canto e da tessitura: "Ela cantava com linda voz/ e com lançadeira dourada sentava ao seu tear." (Homero, 2003, p. 92 vv. 61-62). Segundo Brunuel (2005), Calipso igualmente tece para criar liames que a uniriam a Ulisses e o convenceriam a aceitar a imortalidade, contudo, a pedido de Hermes, a ninfa é obrigada a deixar o fio de seu desejo de lado e transforma-o em fio da viagem. Ela tece com amor as velas da embarcação de Ulisses e, assim, conduz seu retorno em segurança. ${ }^{33}$

Tais figuras míticas colocaram em cena as relações da tecelagem com a sedução e com a magia, reforçando o elo semântico da tecelã e da feiticeira:

A feiticeira mexe o caldeirão, prepara sua infusão e tece a sua teia. $\mathrm{O}$ que as feiticeiras fazem é algo circular, cíclico, como a Lua. Elas fiam e tecem, fazem cerveja e cozinham; sonham e planejam, lançam maldições, encantamentos, leem a sorte, criam enigmas, designam tarefas, interpretam sonhos e fazem profecias. (Koltuv, 1990, p. 102)

Em uma abordagem ancorada no papel social da tecelagem, percebe-se que a mulher e a tecelã são figuras que coincidem. Tecer era a atividade feminina por excelência na Grécia, atividade desenvolvida no confinamento do óikos.

Duby e Perrot (1993) apontam que, devido a questões materiais, não é possível que os historiadores tenham acesso aos discursos femininos para se

\footnotetext{
31 “Dans l'élaboration du mythe de Pandore se retrouvent en effet les couples d'oppositions qui structurent la pensée de l'homme grec. Du côté de l'homme, la culture et la civilisation, la guerre, la politique, la raison, la lumière; du côté de la femme, la nature, la sauvagerie, les activités domestiques, la démesure, la nuit." (Mossé, 1983, p. 98)

${ }^{32}$ BRANDÃO, Junito de Souza. Dicionário mítico-etimológico. Petrópolis: Editora Vozes, 2014, p. 113.

${ }^{33}$ Cf. BRUNUEL, Pierre. Dicionário de Mitos Literário, 2005, p. 380.
} 
elaborar a História das Mulheres Antigas. Com a exceção de Safo, não nos restaram registros escritos por mulheres, de modo que tudo que chegou a nós vem filtrado pelo olhar masculino e, em geral, a escolha dos homens antigos é não falar das mulheres ou falar o mínimo possível. O mundo grego antigo é um universo de homens que se estrutura sobre a guerra e a política, por isso, na maioria dos documentos, deparamos com uma história "contada por homens para homens"34 ". (Mossé, 1983, p. 139, tradução nossa) ${ }^{35}$

Ainda que não tenhamos acesso a muitos documentos históricos que atestem como se desenrolava o universo feminino grego, a iconografia e a literatura deixam visível o vínculo inseparável do feminino e da tecelagem: "A mulher é a sua tecelagem (Bergren, 2008, p. 6, tradução nossa). Uma vez que o registro histórico estrito não é acessível, o percurso de investigação se volta para a construção de um imaginário do feminino e suas representações. No entanto, a forte relação entre discursos e práticas permite notar que "estes discursos integram-se em práticas que determinam a vida das mulheres." (Duby e Perrot, 1993, p. 26)

Na obra História das Mulheres - A Antiguidade, os autores afirmam que " A história das mulheres é, de uma certa forma, a história do modo como tomam a palavra." (Duby e Perrot, 1993, p. 10). E essa história se inicia com o silêncio: em um primeiro momento, as mulheres apareciam apenas na qualidade de tema para literatura e a palavra lhes era interdita: "Se a escrita e o silêncio se reconhecem nesse caminho que os separa da fala, a mulher, silenciosa por tradição, está perto da escrita. Silenciosa porque seu acesso à fala nasceu no cochicho e no sussurro" (Kamenzain, 1981, tradução nossa). ${ }^{36}$

Consoante Mossé (1983), ao olharmos para o mundo grego, por meio da epopeia, da poesia lírica, do teatro, da filosofia, estamos analisando uma sociedade dominada pelos homens. A família patriarcal constitui uma das bases da civilização ocidental, mediterrânea e europeia, de modo que a história das mulheres gregas é a trajetória marginal, que deve ser investigada minuciosamente nos veios dos seus silêncios. Mossé sugere que se busquem os mecanismos da inferiorização feminina,

\footnotetext{
34 “racontée par des hommes pour des hommes" (Mossé, 1983, p. 139)

35 "Woman is her weaving"”" (Bergren, 2008, p. 6)

36 "Si la escritura y el silencio se reconocen una a otro en ese camino que los separa del habla, la mujer silenciosa por tradición, está cerca de la escritura. Silenciosa porque su acceso al habla nació en el cuchicheo y el susurro." (Kamenzain, 1981).
} 
seja por meio de sua ausência nos registros históricos, seja por meio de sua representação na literatura.

Segundo o autor, a mulher grega desempenhava o seu papel social no seio do óikos, unidade fundamental da sociedade grega. Nos poemas homéricos é possível perceber que o poder também emana do óikos e de que forma a boa administração dessa propriedade está intimamente ligada às virtudes femininas, conforme nos apresenta a personagem Penélope. Em Homero, divisam-se duas categorias de mulheres: as esposas e filhas dos heróis e suas servas. O matrimônio aparece como uma situação social inelutável, ou se é esposa ou se será, contudo os enlaces matrimoniais muito se assemelham a uma troca comercial em que se criam laços de dependência e solidariedade entre as casas.

Assim, salvo raras exceções, os trabalhos fora de casa eram realizados por homens. A fabricação de tecidos era realizada por mulheres no interior das casas e constituía uma indústria doméstica feminina. As mulheres eram habituadas desde a infância aos trabalhos de fiar e tecer: "A fiação e a tecelagem eram indiscutivelmente as principais formas de artesanato possíveis às mulheres." (Cardoso, 2006, p. 94). A roca, portanto, acompanha a vida feminina. Cardoso (2006) ainda destaca que os três momentos essenciais de atividade feminina são: a tecelagem, a dança e o casamento.

Em sua obra, Mossé (1983) igualmente mostra que os poemas homéricos oferecem um panorama preciso da condição da mulher grega arcaica. As funções femininas estavam ligadas à boa administração do óikos, ao matrimônio e, no caso das esposas dos heróis, à realeza - sempre restrita para as mulheres:

é mais comumente em seu quarto, cercada por suas amas, que ela se mantém, fiando e tecendo. E, entretanto, se essas honradas <rainhas> tentassem fazer ouvir sua voz ou lamentar a sua sorte, eram rapidamente reenviadas a suas atividades normais. (Mossé, 1983, p. 33, tradução nossa). ${ }^{37}$

Esse papel inferior da mulher, que é afastada da palavra, fica evidente no Canto I da Odisseia, no qual Telêmaco ordena à mãe que retorne aos seus aposentos para fiar e deixe a palavra para os homens.

Ainda consoante os estudos de Mossé (1983), as mulheres na Grécia Antiga eram tratadas como minoria, ao lado das crianças, estrangeiros e escravos. Apesar

\footnotetext{
37 “C'est le plus souvent dans sa chambre, entourée de ses servantes, qu'elle se tenait, filant et tissant. Et si ces <<reines>> pourtant honorées s'avisaient de faire entendre leur voix ou de gémir sur leur sort, elles étaient bien vite renvoyées à leurs activités normales." (Mossé, 1983, p. 33)
} 
da divergência na estrutura de cada pólis, as mulheres, de modo geral, não tinham participação política nem relevância na vida pública da ágora. Tal falta parece exigir a existência de um discurso metafórico "um silencioso substituto para a (sua falta de) arte verbal”38 (Bergren, 2008, p. 16, tradução nossa). Desse modo, a tecelagem talvez seja o primeiro elo que resgata a voz e a autoria da mulher grega, já que a tecelagem é a "atividade feminina produtora de signos por excelência na Grécia" ${ }^{39}$ (Bergren, 2008, p. 15, tradução nossa).

Logo, a tomada do discurso pelas mulheres se iniciou no âmbito doméstico, no espaço de convivência entre mulheres, criado pela tecelagem, que "reforçou também as comunidades femininas, de mulheres que passavam o dia reunidas, tecendo juntas (...) narrando e explorando as palavras, com poder sobre sua própria produtividade e autonomia de criação."(Machado, 2001, pp. 26-27)

Para a crítica, essa afinidade muito particular entre mulher e tecelagem entrará para a literatura não só como metáfora da escritura, mas também como símbolo de resistência e libertação, pois, ao longo da história, as mulheres foram trocando agulhas por palavras e ressignificando sua relação com o tear, já que se tornou: "aquela que tece com perfeição fios que irão um dia orientar sua própria saída do labirinto, desafiando o patriarca e derrotando o tirano. E criar um novo tecido." (Machado, 2001, p. 51)

Diversos aspectos permitiram a associação entre escrita e tecelagem. Primeiramente, a etimologia une os universos têxteis e textuais, mas é o mito que os enlaça definitivamente: "Quando falta a palavra, o tecido torna-se texto, etimologia e mitologia testemunham a mesma aproximação entre escrita e tecelagem" (Sylvie Ballestra-Puech, 2002, p. 1833, tradução nossa) ${ }^{40}$.

Além disso, a tecelagem evoca a criação, pois transforma uma matéria prima bruta, como o algodão ou o linho, em um produto delicado, uma vez que "fiar e tecer são atividades de transformação da natureza em cultura, de criação." (Machado, 2001, p. 24). O fuso, ao transformar matéria vegetal ou animal em tecido, resgata a transformação do pensamento amorfo em palavra, bordada linha a linha no papel.

Ainda vale ressaltar que, na tradição grega, o poeta era vinculado à arte da tecelagem pois: "Como a sua tapeçaria [da mulher], o texto do poeta pode

\footnotetext{
38 "a silent substitute for (her lack of) verbal art" (Bergren, 2008, p. 16)

39 "sign-making activity of women par excellence in Greek" (Bergren, 2008, p. 15)

40 "Lorsque la parole vient à manquer, le tissu devient texte, étymologie et mythologie témoignant de la même proximité entre tissage et écriture" (Sylvie Ballestra-Puech, 2002, p. 1833)
} 
suspender, reverter e reorganizar o tempo. Ele pode tecer o conteúdo de um mundo, real ou imaginário, nos interstícios de um outro." ${ }^{41}$ (Bergren, 2008, p. 12, tradução nossa). Tanto a narrativa quanto a tecelagem são artes que controlam o tempo e o espaço, seguem a ordem linear e dependem de um entrecruzamento de eixos: no domínio linguístico, entre paradigma e sintagma e no têxtil, entre as linhas verticais e horizontais da trama.

A tessitura, portanto, liberta a mulher grega do silêncio e tem a propriedade de narrar : "A mulher grega não fala, tece. Semioticamente a mulher é uma tecelã (...) Nesse sentido, a tessitura feminina é uma "escrita" ou arte gráfica pois se constitui como uma silenciosa representação material do discurso audível e

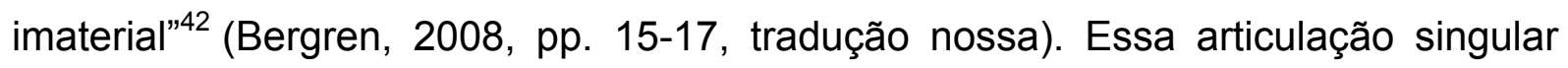
entre silêncio e discurso, linhas e vazios, flexibilidade e resistência, natureza e engenho faz do tear a metáfora por excelência da criação artística, sobretudo narrativa: "Se a tessitura pode ser uma imagem da criação verbal não seria, sobretudo, porque o ar circula entre os fios como o silêncio entre as palavras, esse silêncio sobre o qual a jovem Parca de Valéry afirma que ele <<é a estranha fonte dos poemas $>>?^{43}$ (Sylvie Ballestra-Puech, 2002, p.1835, tradução nossa)

A estreita relação entre o feminino e a tecelagem, no entanto, não se restringe à Grécia Antiga, perdurando até atualidade. Contudo, seria impossível dar conta de esmiuçar historicamente tal hiato temporal que separa o mito das tecelãs da literatura brasileira do século XX em uma leitura de natureza temático-comparativa. Precisaríamos dedicar um trabalho exclusivamente à história para dar conta de momentos históricos tão distintos não só no tempo como também no espaço. Portanto, optamos por dar uma menor ênfase ao foco histórico, sublinhando apenas alguns traços que consideramos profícuos para as análises.

Pensando na formação do contemporâneo, a Revolução Industrial é certamente um momento histórico basilar, que também alterou a posição ocupada

\footnotetext{
41 "Like her tapestries, his "texts" can suspend, reverse, and re-order time. He can weave the content from one world, whether real or imagined, into the interstices of another" (Bergren, 2008, p. 12)

42 "imateriaGreek woman don't speak, they weave. Semiotic woman is a weaver (...) In this way, women's weaving is a (...) "writing" or graphic art, a silent, material representation of audible, immaterial speech.". (Bergren, 2008, pp. 15-17)

43 “Si le tissage peut être une image de la création verbale, n'est-ce pas surtout parce que l'air circule entre les fils comme le silence entre les mots, ce silence dont la Jeune Parque de Valéry dit qu'il <<est la source étrange des poèmes >>" (Sylvie Ballestra-Puech, 2002, p.1835)
} 
pela tecelagem na vida cotidiana. Consoante Lévi-Strauss, ${ }^{44}$ há duas revoluções que cindem a história da humanidade: a Revolução do Neolítico, em que o homem se fixa e desenvolve a agricultura e, portanto, a trama, e a Revolução Industrial, em que se desenvolve a noção de produção em larga escala e o imperialismo. Consequentemente, esses dois momentos históricos terão impacto singular sobre a cultura: a Revolução do Neolítico permite o seu desenvolvimento e a Revolução Industrial inaugura a mercantilização e automatização dos produtos culturais.

Assim, a tecelagem, que ocupava uma posição de prestígio na esfera da manufatura, é deslocada para o segundo plano com o desenvolvimento da indústria têxtil. Segundo Machado (2001), tecer e fiar foram atividades majoritariamente femininas até a invenção do tear mecânico no século XIX. Os tecidos figuram entre os primeiros produtos manufaturados a serem comercializados e desempenharam papel central nas economias europeias. O trabalho de tecer era realizado dentro das casas pelas mulheres, mas comercializado no exterior pelos homens, permitindo que "os homens que comercializavam ocultassem essa evidência e pudessem negar a dependência da produtividade feminina." (Machado, 2001, p. 26)

Segundo Machado (2001), a visão moderna, acostumada à produção industrial, muitas vezes não nos permite notar como a produção artesanal levava tempo. Qualquer vestimenta era urdida manualmente, desde o preparo do fio até o tingimento, corte e costura do modelo. Todo esse processo fazia da vestimenta um item muito valorizado nas culturas antigas, basta pensar na importância do enxoval em um contrato matrimonial de sucesso. Há ainda muitos registros de tecidos delicados compondo os dotes de casamento: "a vida social das mulheres esteve profundamente conectada à vida social da roupa" (Stallybrass APUD Machado, 2001 , p. 29) ${ }^{45}$.

Ao reservar à mulher a interioridade da casa e ao homem as transações comerciais, a tecelagem igualmente "permitiu a domesticação feminina, o confinamento da mulher no espaço doméstico." (Machado, 2001, p. 26). Além disso, o trabalho feminino não é valorizado enquanto capital simbólico, o tecido tem forte valor mercantil, mas é dissociado da mulher:

\footnotetext{
${ }^{44}$ Diversas reflexões sobre a história da tecelagem foram sugeridas pela professor Carla Cristina Garcia em sua palestra "Artes Têxteis e o Feminismo no Ocidente", ministrado no Centro de Pesquisa e Formação do SESC como parte do conteúdo programático do curso Arte Têxtil: entre tramas e resistências em São Paulo em maio de 2017.

${ }^{45}$ Cf Stallybrass, Peter. O casaco de Marx, Belo Horizonte: Autêntica Editora, 1999.
} 
o trabalho doméstico da dona-de-casa, seu valor e esforço, sua contribuição ao bem-estar social, não é reconhecido como trabalho e não se reveste, portanto, de prestígio social. A economia do sistema extrafamiliar trata de esquecer e desconhecer esta economia paralela à qual serve e na qual se apoia, que é o sistema econômico familiar. E, como assinala Duran (1983), “à força de ignorá-lo, de excluí-lo de seus cálculos, e de sua linguagem, chega a parecer que é imutável, gratuito, não custoso, não valorizado... e a um passo de supor que, uma vez, que é improdutivo, quase não tem valor" (p. 11) (...) Sua dedicação exclusiva ao trabalho doméstico impede ou dificulta a participação autônoma das mulheres nos espaços públicos, que ficam restritos aos homens, levando-as a uma marginalidade social. (Coutinho, 1994, p.33)

Permanecendo em casa, a mulher não acessa a educação formal e se distancia do universo das letras: "Em outras palavras, a circulação da matéria têxtil criada por mulheres era incentivada, mas a circulação do texto e da palavra da mulher encontrava todos os obstáculos." (Machado, 2001, p. 33)

As mulheres irão se aproximar dela muito lentamente: Primeiro, nas conversas e cantigas realizadas no espaço de trabalho; em um segundo momento, nos cadernos de receitas que mesclavam receitas, confissões, poemas e impressões pessoais; posteriormente, nos diários e na troca de cartas, chegando muito tardiamente à literatura. Segundo Machado (2001, p. 31) a opção da cultura dominante por colocar os trabalhos de agulhas e o estudo como incompatíveis refletia o desejo de limitar a autonomia feminina. ${ }^{46}$

Coutinho (1994) assinala que a Revolução Sentimental do século XVIII intensificou ainda mais o papel de passividade feminino. O amor romântico, ao ser fortemente valorizado, criou uma situação de mistificação do feminino, que será espelhado no amor materno. Ao se tornar personificação do amor e da alteridade, a mulher passa a viver para amar os filhos e o marido. Nesse contexto, estava destinada a preencher requisitos pré-determinados e amplamente esperados por toda a sociedade, inclusive por outras mulheres.

A mulher da classe média era exposta em uma espécie de vitrine, quando considerada pronta para o casamento e sua vida social orbitava ao redor desse evento. Cristopher Lasch (1999) discute esse cenário do século XVIII e aponta, dentre outras pensadoras, Mary Wollsstonecraft, como uma crítica dessa situação a que a mulher era submetida à época.

\footnotetext{
${ }^{46}$ Não havia motivos reais para que a cultura dominante tentasse apresentar o estudo e os trabalhos de agulhas como incompatíveis, a leitura como um obstáculo à feminilidade. A não ser o mecanismo para manter a mulher ignorante - e, portanto, obediente, reclusa, sem iniciativa própria, confinada ao âmbito doméstico. (Machado, 2001, p. 31)
} 
Embora os costumes ratificassem que após o casamento o mundo feminino deveria girar em torno do âmbito doméstico, voltado aos afazeres que atendessem à família, como domínio feminino por excelência, despontavam investigações e reflexões que questionavam esse papel reduzido reservado às mulheres. Era-Ihes vetada a rua como espaço de atuação, destinado exclusivamente ao homem, ou melhor, a determinados tipos de homens, valendo como critério os já conhecidos aspectos sociais e políticos.

Essa perspectiva reducionista na atuação da mulher é abrandada com os questionamentos advindos de importantes manifestações feministas, que reivindicavam, por exemplo, o âmbito político como também pertencente, senão de fato, pelo menos de direito, ao universo da mulher. Diderot já defendera que a "inferioridade feminina" foi em grande parte causada pela sociedade. O filósofo afirma que as mulheres foram largamente tratadas como seres inferiores em vários aspectos, especialmente no que se refere à capacidade de pensar. Simone de Beauvoir assinala em seu O Segundo Sexo (Beauvoir, 2009, p. 167) que, nesse período, o confinamento feminino se deve à noção de que as mulheres pertenciam à família e não à sociedade política e que a natureza as havia feito para as tarefas domésticas e não para as funções públicas. ${ }^{47}$

Essa incômoda situação - a unívoca presença masculina na sociedade - é foco de alerta de algumas manifestações, já a partir do século XVIII. Tal qual o casamento, a vida pública passa por análises e recebe diversas críticas de figuras importantes como Hanah Moore e a já citada Mary Wollsstonecraft.

No século XIX, essas reflexões tomam corpo e se tornam não somente mais conhecidas, mas sobretudo recebem adesão de mais pensadores e, vale ressaltar, amplia-se a sua popularidade, ainda que fossem relativamente pouco apoiadas pelo público masculino. A cisão do particular (como instância eminentemente feminina) em detrimento do público (domínio masculino) passa a ser questionada veementemente. Segundo Cristopher Lasch (1999), a separação radical entre vida

\footnotetext{
${ }^{47}$ A liberdade de espírito, herdada do século XVIII, não fere a moral familiar; esta permanece tal qual a definem, no início do século XIX, os pensadores reacionários como Joseph de Maistre e Bonald. Estes assentam na vontade divina o valor da ordem e reclamam uma sociedade rigorosamente hierarquizada: a família, célula social indissolúvel, será o microcosmo da sociedade. "O homem está para a mulher como a mulher para a criança; ou o poder para o ministro como o ministro para o súdito", escreve Bonald. Assim, o marido governa, a mulher administra, os filhos obedecem. O divórcio é naturalmente proibido e a mulher é confinada ao lar. "As mulheres pertencem à família e não à sociedade política, e a natureza as fez para as tarefas domésticas e não para as funções públicas", afirma ainda Bonald. (Beauvoir, 2009, p. 167)
} 
pública e privada que irá estruturar o lar moderno foi uma invenção do século XIX. A família passou a ser um espaço de proteção diante do mundo insensível das máquinas. O autor, no entanto, apresenta dados concretos que rompem com o senso comum de que a mulher nesse século esteve confinada às atividades domésticas: elas organizaram movimentos filantrópicos, cruzadas contra a escravidão e lideravam o movimento para a liberação da mulher, por exemplo.

Esses questionamentos desdobram-se na Primeira Onda Feminista, compreendida entre o final do século $\mathrm{XIX}$ e início do século $X X$, os movimentos organizados de mulheres conquistaram o sufrágio universal e permitiram a visibilidade feminina, quanto ao elo com o bordado e a tecelagem destacam-se nesse período os bordados políticos das sufragistas, que usavam a técnica em suas reinvindicações.

A Segunda Onda Feminista localizada historicamente a partir da década de 60 do século $X X$, veio consolidar os direitos femininos com a reinvindicação da entrada da mulher no mercado de trabalho com equidade de funções e com a luta pelo direito à sexualidade, representado pela pílula anticoncepcional. O período compreendido entre a década de 60 e 80 vive um momento de rejeição às artes têxteis. Essa negação foi vista pelas mulheres do período como uma recusa a todos os valores de submissão comumente atribuídos à tecelagem. Por outro lado, o século $X X$ viu crescer o número de mulheres oficialmente engajadas na escritura, que não precisavam mais recorrer a pseudônimos para conseguirem fazer os seus textos circular. Assim, as mulheres foram trocando agulhas por canetas em um movimento de reescritura de seus papéis e subjetividade.

Produto desse mesmo movimento pendular entre opressão e resistência, a história das mulheres no Brasil, apresenta uma série de paralelos com o silêncio das mulheres gregas. Não por acaso, a canção de Augusto Boal e Chico Buarque Mulheres de Atenas encontrou tanto eco em terras tupiniquins. O nosso patriarcado tropical foi também crudelíssimo e, apenas nas últimas décadas, uma parcela das brasileiras conseguiu desprender-se parcialmente das opressões diárias.

Desde o Brasil colônia, a família brasileira apresenta "organização patriarcal dupla" ${ }^{48}$, centralizada na figura do homem que dominava a política, a economia,

\footnotetext{
48 "núcleo central, legalizado, composto pelo casal branco e por seus filhos legítimos; e um núcleo periférico nem sempre bem delineado, constituído de escravos e agregados, índios, negros, mestiços, no qual estavam incluídas as concubinas dos chefes e seus filhos ilegítimos" (Cândido (1951), APUD, Coutinho (1994, p. 29)
} 
comandava os escravos, empregados e agregados, bem como controlava a mulher e os filhos. A mulher brasileira do período colonial também estava restrita ao espaço doméstico e a fiação e a tecelagem faziam parte de suas atividades cotidianas:

Também foram elas que, com a ajuda das mucamas, fiaram o algodão, fizeram as rendas, bordados e trabalhos de agulha para serem usados nas vestimentas e nos lares da época. (...) A casa-grande era dirigida por estas mulheres que, silenciosas mas com mãos de ferro, deram feição a ela e, mais tarde, também aos sobrados da cidade, raramente aparecendo a quem não fosse parente próximo pelo sangue ou compadrio. Seu mundo resumia-se à casa e à família. (Coutinho, 1994, p. 70)

A autora defende que a chegada da família real ao Rio de Janeiro em 1808 muda radicalmente a sociedade brasileira, permitindo às mulheres das classes mais ricas uma aproximação com o modo de vida europeu, em que bailes, teatros, festas e saraus eram espaço de circulação feminina. No final do século XIX, as melhorias na urbanização e no saneamento da cidade, a propagação do trabalho assalariado e a ascensão da classe média levará a um lento declínio da família patriarcal tradicional, passo decisivo para uma maior visibilidade feminina.

A educação, no entanto, permaneceu por muito tempo descompassada. A menina, até o final do século XIX, quando surgiram as primeiras escolas normais, tinha acesso a uma educação elementar, muitas vezes privada da leitura e da escrita. Para as que sabiam ler, a leitura ficava restrita às obras românticas. 0 acesso à educação para as mulheres iniciou-se para torná-las companhias mais agradáveis aos homens. Assim o francês, o piano e as prendas domésticas passam a lapidar a "boa esposa". Segundo Coutinho (1994), como o casamento era uma instituição de ascensão ou manutenção de status, as famílias passaram a investir na formação mais matizada das moças, que podiam aprender, além da culinária e do bordado, francês, piano, canto e dança.

No século $X X$, sob influência do american way of life, a mulher mantinha-se em seu papel de dona-de-casa e mãe. Isolada em casa, a mulher não questionava sua condição. Com a eclosão dos movimentos feministas nos países de primeiro mundo no final dos anos 60, a mulher brasileira também passou a reivindicar novos espaços: "O feminismo funcionou, assim, para dizer não a toda uma ordem patriarcal que dava à mulher um lugar secundário (...) de modo geral, o movimento alcançou êxito, modificando consideravelmente as relações homem-mulher e o papel desempenhado por esta na sociedade." (Coutinho, 1994, p. 113) 
No século $X X I$, a mulher já conquistou espaço na sociedade brasileira, embora a igualdade de gêneros não seja ainda uma realidade. Grande parte das mulheres na atualidade assume sua sexualidade, seus percursos acadêmicos e profissionais, bem como a autonomia em relação à figura masculina. No entanto, a mulher contemporânea tornou-se uma mulher-elástico, que deve desempenhar as funções relativas à esfera profissional e doméstica com a mesma excelência. Evidencia-se, portanto, um acúmulo de funções que ainda denota uma posição assimétrica entre homens e mulheres. Outras opressões relacionadas a resquícios do patriarcalismo ainda são presentes no cotidiano da maioria das brasileiras, mas que hoje possuem voz para contestá-lo.

Em suma, ao longo da história as mulheres foram tecendo e narrando seu próprio processo de emancipação, costurando alianças femininas que resistiram às múltiplas opressões e permitiram a descoberta de uma voz tão habituada ao silêncio:

personagens de ficção ou mulheres reais, desde as mais remotas épocas, de mãe para filha e de avó para neta, vieram nos bastidores tecendo seus fios, emendando carreiras, dando pontos e fazendo nós numa espécie de grande texto coletivo: o tecido da História composto pelas linhas entremeadas das histórias. (Machado, 2001, p. 50) 


\section{O firme fascínio: nas teias da sedução}

(...) Linho dos seios na roca dos sentidos a seda lenta sedenta na garganta

a lã da boca cardada no gemido

e nos joelhos a sede que os abranda

Linho das ancas bordado de torpor

a boca espessa o fuso da garganta (Maria Teresa Horta)

A obra rosiana configura-se como locus privilegiado da esfera mitopoética. Rosa coloca em seu infinito sertão heróis míticos apequenados, galgando as odisseias do cotidiano, as batalhas entre jagunços, fazendeiros e vizinhos, as belas moças helenas de pés descalços e vestidos de chita:

Com Guimarães Rosa parece que cessa a urgência desse diálogo. O mito, posto aquém ou além do drama, tende, na sua forma ultimada, a fechar-se às contradições com a sociedade englobante; e goza, no reino encantado da narração poética, as infinitas riquezas do seu próprio ser. (...) Toma conta das coisas, dos animais e das pessoas uma dimensão mais ampla, uma aura que não é a do dia-a-dia normal e socializado (...)

A forma interna dessa comunhão de sujeito e mundo é um estilo que reativa as potências sonoras e simbólicas da palavra. Não se trata de uma simples volta ao vocabulário arcaico ou à frase coloquial sertaneja (...) tratase de estender os princípios criadores da língua mitopoética a todo o tecido narrativo. A palavra nova não é o puro neologismo, pois retoma um processo de formação que vem de longe, de muito longe; assim, de um salto, o tempo é abolido, e o signo - arcaico e moderno - simula o eterno presente. (Bosi, 1997, pp. 12, 13)

No universo rosiano, as mulheres desempenham um papel fundamental e vão ora enredando as demais personagens em suas tramas de sedução, feito Circe e Calipso, ora orientando os heróis para fora dos conflitos, deslindando com delicadeza o novelo de Ariadne. No autor, tal ambivalência do feminino, aguçada nos textos da modernidade, alcança efeito de oxímoro: Há mulheres rosianas que são igualmente pureza e vilania, Penélope, Helena, Pandora de tantos dons. Nos 
contos escolhidos para análise, esse equilíbrio desnorteador é percebido nos olhos de viva mosca de Livíria e nas tramas ardilosas de Dlena.

Em "Desenredo", podemos observar que o protagonista Jó Joaquim assemelha-se a uma Penélope apequenada que tece e destece a própria narrativa, enquanto Livíria reelabora a linhagem das tecelãs fatais iniciada por Pandora. Já em "A vela ao diabo" (2001) as tecelãs aparecem nas figuras de Zidica, herdeira de Penélope, e Dlena, herdeira de Pandora.

Essas narrativas, publicadas em 1967 na obra Tutameia, além de articular em nossos objetos de estudo (intertextualidade e tematização da criação literária) representam magistralmente a poética rosiana ${ }^{49}$. Segundo Nunes (2009), Tutameia configura um locus estético privilegiado para a investigação de referenciais mitológicos, pois enquanto obra resgata um discurso de ordem mítica:

São estórias de uma só estória; são casos exemplares, a modo de diversa figuração de grande fábula ou mito. Isso, se dermos à fábula o sentido de ensinamento indireto, que se extrai, por via de ação de pessoas, animais ou coisas, e se por mito entendermos, respeitando a etimologia, história que personaliza verdades ou princípios essenciais. (Nunes, 2009, p. 195)

Segundo Gama (2002), a obra Tutameia, pode ser considerada o testamento estético de Guimarães Rosa, uma vez que questiona a (re)leitura literária. Durante a travessia imposta por Tutameia, mesmo aos barquinhos de papel, "o leitor é informado sobre a incompletude de sua primeira leitura e, logo, não está frente a um encadeamento que o levará a um sentido possível de ser apreendido num fluxo contínuo; é impelido a parar, reler, tecer relações, interagir com o livro." (Gama, 2002, p. 309).

Nesse sentido, a espera e a paciência estão imbricadas na concepção estética de Tutameia. Rosa propôs um livro no qual a espera é imperativa, de modo que o leitor diante dela também é Penélope tecendo e destecendo sentidos, também é Jó Joaquim enredando e desenredando as tramas com as agulhas da paciência. É preciso tecer e destecer o conto, ler e reler, e nessa espera, nesse movimento pendular, o leitor reconhece sua própria incompletude (Esperar é reconhecer-se incompleto!) e a impossibilidade de decifrar toda a opacidade (Bosi,

\footnotetext{
${ }^{49}$ Guimarães Rosa mostra sua inventividade, na construção de um universo mitopoético. Seja pelo tema, seja pela linguagem ninguém o supriu no campo do imaginário (...) Desde os seus primeiros contos sua luta contra a imobilidade da linguagem conseguiu, usando todos os recursos permitidos sem desfigurar a língua, transformar a prosa em linguagem mítica. (Turchi, 2003, p.54)
} 
2010, p. 461) da palavra rosiana: "Tutameia, tomada em conjunto, propõe a provisoriedade de todo fim, a infinitude do narrar." (Novis, 1989, p. 138)

Nesse próximo capítulo poderemos investigar mais de perto tais questões, sem a pretensão de exauri-las, já que os contos pedem recorrentemente para serem relidos.

\title{
2.1 Enredando ardis, Desenredando tramas
}

\author{
Também o poeta é um artista do tecer \\ e entretecer porque, engenhoso, \\ conjuga as histórias metamórficas \\ em um único e amplo tapete de metamorfoses, \\ o tapete das ficções. (Karl Stierle)
}

O conto "Desenredo" configura-se como uma espécie de fio condutor do trabalho, pois, nele, a intertextualidade e a tematização da criação literária mesclam-se com contundência ao lirismo, de modo que o próprio conto torna-se produto de um labor artesanal cuja matéria prima é a palavra. Logo, iniciamos a pesquisa por sua análise e a partir dela articularemos as demais narrativas do corpus.

Publicado em 1967 na obra Tutameia, "Desenredo" também revela as especificidades da poética rosiana. Segundo Turchi (2003, p, 54), Guimarães Rosa constrói um universo mitopoético e, por meio da linguagem poética, transforma a prosa em linguagem mítica.

Ao adentrarmos um conto de Guimarães, inevitavelmente entramos em contato com todo o universo de sua escrita, dentro do qual o círculo hermenêutico revela-se fundamental: cada lexema empregado pelo autor pode remeter ao conjunto de sua obra e a apreensão do sentido geral das suas narrativas depende muito da análise do pormenor. Rosa é um autor cuja obra oscila entre o geral e o particular, dando conta de ambos com maestria, em um "movimento pendular" (Passos, 2001, p. 21) que alcança a sua plenitude na ambiguidade dos rearranjos e deslocamentos entre arcaico e moderno, verdade e logro, camuflagem e desvelamento, como apontado pela autora.

Na esteira da reflexão de Passos, o conceito de "rearranjo" é essencial para a análise de "Desenredo", uma vez que Rosa rompe com a tradição literária ao escrever o seu des-enredo, isto é, a sua proposta é subverter o enredo tradicional. 
Dessa forma, o conto é um bom exemplo do que Cleusa Passos denomina o "contar desmanchando":

procedimento que, de um lado, constrói cenas e personagens, expõe dados sociais e psíquicos, desperta no leitor ressonâncias sutis de causos e estórias (presentes em sua obra ou na tradição literária) e, de outro, os desenreda. Paralelamente à mistura de temas, tempos, formas literárias e subversões verbais, já assinaladas pela crítica, o ato de desenredar se mostra elemento importante da obra do autor. Por vezes, os dois aspectos, artifícios de seu fazer artístico, contaminam-se, condensando mascaramento e revelação. (Passos, 2001, pp. 22, 23)

Nesse sentido, "Desenredo" pode ser concebido como a própria síntese da poética rosiana que se vale dos enredos tradicionais para subvertê-los e criar desenredos, "contrário(s) ao público pensamento e à lógica" (Rosa, 2001, p.74). Na esteira de Passos (2001), podemos observar que esse procedimento está presente tanto na "mudança de relações do casal-protagonista (Jó Joaquim e Livíria/ Rivília/ Irlívia), quanto opera a reelaboração de elementos bíblicos (Adão/Eva, Jó) e ficcionais (Odisseia), reiterando-se aí a inserção de suas produções na história e tradição literárias." (Passos, 2001, p. 23).

O conto narra, em linhas gerais, a trajetória de Jó Joaquim, personagem que reescreve sua história por meio da subversão do enredo tradicional a fim de transmutar o adultério cometido pela amada, Livíria, e retomar o relacionamento. Contudo, o que interessa aqui, é, sobretudo, o movimento de fazer e desfazer, enredar e desenredar realizado por Jó Joaquim, inserindo a personagem na tradição de Penélope, que recorre à sua astúcia para, graças a um ardil, vencer o tempo e postergar o casamento, solicitado pela nobreza de Ítaca, a fim de que um dos pretendentes que a pressionam assuma o lugar de Ulisses.

Jó Joaquim também molda o tempo, não para adiar uma ação, mas para revertê-la: "Jó Joaquim, genial, operava o passado - plástico e contraditório rascunho." (Rosa, 2001, p. 74). Enquanto o produto da tessitura de Penélope é têxtil, o produto das agulhas de Jó Joaquim é textual e discursivo, tão bem articulado que se torna realidade, concretude: "Criava nova, transformada realidade, mais alta. Mais certa?" (Rosa, 2001, p. 74). O verbo criar reforça a concepção de Jó Joaquim como uma apequenada Penélope dentro da composição narrativa: ambos tramam ardis astuciosos, ora no tear, ora no papel: Penélope, a fim de evitar o casamento, continuar à espera de Ulisses e não permitir que outro se aproprie do reino de Ítaca; 
já o humilde Jó para apagar a traição da esposa e poder retomar seu amor também interrompido, não por uma guerra, mas pelo adultério.

À medida que realizamos uma leitura rente ao texto, percebemos que "Ao criar seu universo, o escritor lembra, metaforicamente, o artesão que tece ou molda o objeto, dedicando-se ao minucioso trabalho de manipulação das escolhas, rearranjos e desarticulações do verbo, com o intento confesso de representar o mundo" (Passos, 2001, p.33).

A narrativa "nos obriga a acompanhar, simultaneamente, a ficção e seu fazer artístico" (Passos, 2001, p. 27), ou seja, em "Desenredo" e nos demais textos selecionados para análise e interpretação temos esse movimento: não só o de uma ficção simultânea ao seu fazer artístico, mas sobretudo de uma ficção que tematiza uma criação que se desenrola, paralelamente, a seu fazer artístico, de modo que a tessitura e a criação a operam em dois níveis: a criação realizada pelas personagens (com relação a "Desenredo", a posse de Jó Joaquim da sua própria história) e os recursos poéticos usados para urdir a trama, tendo a intertextualidade por procedimento pilar de composição, pois os textos inserem-se em uma teia que os liga não só aos mitos das fiandeiras, por exemplo, mas, particularmente, a outros textos. No caso de "Desenredo" à Bíblia, no da "Moça Tecelã" aos contos de fadas tradicionais, em "Penélope" à estrutura trágica etc. A argumentação de Vera Novis reforça a nossa hipótese:

A dimensão metalinguística do texto está em que Jó Joaquim relê o
passado para desenredar a sua estória (“Jó Joaquim operava o passado -
plástico e contraditório rascunho."), ao mesmo tempo em que Rosa cria seu
"Desenredo" passando em revista a tradição romanesca. Todo o conto é
perpassado de fina ironia em relação aos modos do narrar, tanto da tradição
romântica quanto da tradição realista, aos personagens, ao leitor; até o
narrador imola-se nesse processo. (Novis, 1989, p. 136)

A paciência e a astúcia, qualidades comumente atribuídas à heroína homérica, são reatualizadas por Rosa: "Jó engendra o desmanche da traição pelo mesmo processo que estigmatizara a mulher: a repetição" e graças a sua "infinita paciência" (Passos, 2001, p.24). Também Penélope repete a cada dia o seu bordado com infinita paciência, e, metonimicamente, o próprio bordar só se opera pela repetição de ponto após ponto, assim como o texto de Jó só poderia ser escrito pela tessitura de palavra por palavra.

Contudo, a repetição também reforça o inverso: um tecido é urdido ponto a ponto, mas é também dessa maneira que é possível desmanchá-lo. Ainda sobre a recorrência é preciso lembrar que o poema épico é composto por meio dela, já que 
depende de técnicas mnemônicas para a sua circulação, pois constituía um gênero da oralidade, só mais tarde fixado em papel. A estruturação do conto pela repetição, portanto, reforça a hipótese intertextual. Conforme sabemos, conteúdo e forma não podem ser dissociados na análise literária: "em "Desenredo" temos o narrador do código da escrita que conta a ouvintes quase um poema em prosa, no qual o ritmo e a repetição são fundamentais, pois mantêm o leitor na poesia" (Gama, 2002, p. 316).

Desse modo, a repetição é fulcral para a estruturação desse conto, em sua fatura e em seus temas. Observa-se a reelaboração da tradição, não só porque as técnicas de composição mnemônicas da poesia são resgatadas e alteradas na composição da prosa poética, mas também pois a trama se faz a partir dos adultérios de Livíria que se repetem e apresentam alterações internas, como a mudança dos papéis de amante e marido:

Por meio de triângulos amorosos, formados e desfeitos, que alimentam o relato, o narrador vai engendrando um tipo de brincadeira capciosa, em que a mobilidade de cada elemento que o constitui, cada palavra escolhida, desempenha um papel fundamental. Essa mobilidade se manifesta na própria construção, forjada com frases curtas, concisas, às vezes, monossilábicas, às quais o artista empresta caráter enigmático. Em nada trivial, esse sistema de articulações se processa em diferentes níveis de complexidade, transitando da relação individual para a coletiva. (Montagna, 2011, p. 02)

Já a paciência remete a uma dupla referência, além de Penélope e a sua espera ao longo de 20 anos, chega-nos o eco do Jó bíblico e sua paciência, recobrado pelo nome do protagonista: Jó Joaquim. Dessa maneira, as leituras tradicionais da literatura ocidental, no caso a Bíblia e a Odisseia, são retomadas por Rosa de modo que o " o leitor é preparado para participar ativamente da leitura (inclusive convidando-o à releitura). As narrativas lidas anteriormente ecoam continuamente na recepção, tecendo novas redes de conexão e instaurando um ritmo próprio." (Gama, 2002, p. 310). A necessidade de participação ativa do leitor na obra Tutameia é antecipada na epígrafe do livro; essa dimensão de decifração e desvelamento, segundo Machado (2003, p. 109), configura-se como uma constante na obra de Guimarães Rosa.

Ainda que o diálogo com as matrizes bíblicas não sejam o foco de nossa análise, a leitura cerrada do Livro de Jó , traz contribuições preciosas para a análise de "Desenredo". O primeiro elemento que vale ser destacado é que o Livro de Jó inicia-se com a fórmula "Era uma vez", apresentando, portanto, uma estrutura fabular semelhante à do conto rosiano. 
A história bíblica narra a trajetória de um homem íntegro e reto, que temia a Deus e evitava o mal. Deus, em diálogo com Satã, destaca as virtudes de Jó, porém Satanás refuta a fidelidade do servo, afirmando que o homem só se mantinha ao lado de Deus por ser afortunado e que, na primeira desgraça, negaria o nome do Senhor.

Deus então permite que Satã tente Jó a fim de testar a sua fidelidade, desde que sua integridade física fosse mantida. Assim, Jó perde seu patrimônio e entes queridos: bois, camelos, ovelhas, empregados, sete filhos e três filhas. Mesmo diante da miséria e do sofrimento, Jó permanece fiel a Deus e, então, Satanás o cobre de doença. ${ }^{50}$ Apesar do sofrimento persistente, Jó mantém-se leal a Deus e daí advém sua relação estrita com a fidelidade e a paciência.

Segundo Pierre Brunuel, Jó é um mito bíblico ocidental ligado ao monoteísmo hebreu ${ }^{51}$, em que se investiga o mistério da justiça de Deus por meio da figura do homem inocente que sofre. Nesse sentido, já percebemos traços que ecoam em nosso Jó Joaquim 52 "quieto, respeitado, bom como o cheiro de cerveja", isto é, em estado de equilíbrio e inocência antes do aparecimento de Livíria e que será recorrentemente testado pelo sofrimento advindo da decepção amorosa diante do adultério. Ainda segundo Brunuel, "Jó é mostrado como uma figura essencial da miséria humana, entre a recusa e a passividade (...) Certas épocas receberam-no como um exemplo de PACIÊNCIA e outras, como um exemplo de REVOLTA."(Brunuel, 2005, p. 525). Nota-se aqui outra semelhança ao Jó rosiano, que não se resigna diante da traição e busca alternativas para continuar ao lado da mulher amada.

Assim como para Jó-Joaquim, para o Jó bíblico "o trágico não vem a contagotas", enfatizando a relação entre as personagens. O trágico para Jó atinge o campo familiar, o campo material e o campo da saúde, levando o servo de Deus a afirmar: "Meus dias correm velozes como a lançadeira, e se consomem sem qualquer esperança."( C.7 v.6-7, Bíblia Sagrada, p. 610).

\footnotetext{
50 "Satã feriu Jó com feridas graves, desde a planta do pé até a cabeça"(C 10. V.07, p. 607).

${ }^{51}$ Cf. Brunuel, Pierre. Dicionário de Mitos Literários. Rio de Janeiro: José Olympio, 2005, p. 525

52 É ainda relevante uma ligação da personagem rosiana com outra personagem bíblica. Trata-se de um texto grego apócrifo, isto é, que não pertence ao cânone hebraico, que conta a história tipicamente popular da bela Suzana, casta esposa de um certo Joaquim, assediada por dois velhos. Furiosos por sua recusa eles a acusam de adultério. (Cury, 2001, p. 101)
} 
Algumas referências quase explícitas ao Livro de Jó permeiam o conto "Desenredo", fazendo parecer que Rosa recria fragmentos do texto bíblico ao desenredar a narrativa. No momento em que Livíria trai Jó Joaquim pela primeira vez, a cena é descrita da seguinte maneira pelo narrador: "Jó Joaquim, derrubadamente surpreso, no absurdo desistia de crer, e foi para o decúbito dorsal, por dores, frios, calores, quiçá lágrimas, devolvido ao barro, entre o inefável e o infando.”.

O fragmento parece dialogar com os sofrimentos abruptos que o Jó bíblico enfrenta e até mesmo com a doença que o atinge: "Os soluços são meu alimento, e meus gemidos transbordam como água. O que eu mais temia aconteceu para mim, e o que mais me apavorava me atingiu. Vivo sem paz, sem tranquilidade e sem descanso, em contínuo sobressalto." (C. 3 v. 24-26, Bíblia Sagrada, p. 608). O sofrimento e a descrença diante da transformação inesperada aparecem para as duas personagens, bem como a imagem da água também é trazida à luz recorrentemente em ambos os textos. Outro eco que aparece no excerto de Rosa é a menção ao barro, que no livro bíblico também tem lugar: "Tuas mãos me formaram e modelaram o meu ser inteiro. E agora tu te voltas contra mim, para me aniquilar? Lembra-te! Tu me fizeste do barro. Queres agora fazer-me voltar ao pó? " (C.10 v.89, Bíblia Sagrada, p. 612).

Os números 3 e 7 são também reiterados no Livro de Jó (sete filhos e três filhas; sete mil camelos e três mil ovelhas), e parecem ecoar em "Desenredo": "Três vezes passa perto da gente a felicidade."; "Mas muito tendo tudo de ser secreto, claro, coberto de sete capas. Tais números também invocam a simbologia e são recorrentes nos contos populares, como analisa Cury (2001). ${ }^{53}$

Outros paralelos também podem ser citados, como o aforismo rosiano "É de se notar que o ar vem do ar, se comparado ao versículo "Deixa-me, para que eu possa respirar um pouco." (C. 10 v. 20, Bíblia Sagrada, p. 613).

O aforismo "Todo abismo é navegável a barquinhos de papel”, igualmente encontra ressonância no texto bíblico: "Por acaso você pretende sondar o íntimo de Deus, ou penetrar na perfeição do Todo Poderoso? (...) Ela é mais profunda que o

\footnotetext{
${ }^{53}$ A cifra 3, além do mais, é símbolo da perfeição na tradição judaica. Jó tinha sete filhos. 7 - duas vezes o número perfeito 3 mais 1 - tem também ligações com a simbologia numérica da Bíblia. Nos contos populares, ensina-nos Vladimir Propp, o 3 é constante: os três irmãos que saem para procurar a fortuna, três provas sofridas pelo herói ou três adivinhações a que se submete, etc. "Três vezes passa perto da gente a felicidade."(Rosa, 1994, :557). Com essa afirmação, a narrativa anuncia sua conclusão. A matriz popular afirmada desde o começo pela via da oralidade acaba por revelar-se, mais uma vez, a "fonte" do erudito: "E pôs-se a fábula em ata" (Rosa, 1994: 554) (Cury, 2001, p. 105)
} 
abismo. O que pode você saber? Ela é mais ampla que a terra e mais larga que o mar." (C. 11 v. 7-9, Bíblia Sagrada, p. 613).

O embate entre pureza e tentação é colocado no Livro de Jó, já que este representa o polo da pureza e a tentação é representada por Satanás. Jó precisa se provar puro e fiel diante do Senhor e passa a questionar o castigo por possuir convicção de sua pureza: "Eu sou puro, e não tenho culpa! Sou inocente e não cometi nenhum pecado!"(C.32 v. 9, Bíblia Sagrada, p. 627). A única possibilidade de mácula considerada por Jó é o contato com a mulher, mácula hereditária desde Eva: Como pode o homem ser puro, como pode ser inocente se nasceu da mulher?" (C 15. v. 14, Bíblia Sagrada, p. 615).

A pureza será textualmente citada no capítulo 14: "Mas quem pode tirar o puro do impuro? (C. 14 v- 4 , Bíblia Sagrada, p. 615). O tema da pureza aparece com bastante força em "Desenredo", tanto na citação explícita ("Soube-se nua e pura"), quanto no processo de purificação discursiva realizada por Jó ao desconstruir o adultério da mulher. Nesse sentido, Jó Joaquim parece justamente "tirar o puro do impuro", contrariando a lógica do texto bíblico e tornando puro o que fora "tão claro como água suja".

O último trecho do livro de Jó que parece ter sido recriado por Guimarães Rosa em sua narrativa é: "Uma árvore tem esperança: mesmo que a cortem, ela volta a brotar e seus ramos continuam a crescer. Embora suas raízes envelheçam na terra e seu tronco esteja amortecido no solo, ao cheiro da água ela solta brotos e produz folhagem como planta nova (C. 14 7-9, Bíblia Sagrada, p. 615), que parece ser evocado no aforismo: "O real e válido, na árvore, é a reta que vai para cima.". Dessa forma, podemos notar que Guimarães Rosa não só dialoga com o mito de Jó e os sentidos da paciência e da fidelidade que o mito inspira, mas também reconstrói fragmentos do livro bíblico na arquitetura de seu "Desenredo":

\footnotetext{
Ao retomar a trapaça convencional da sedução de Eva (literalmente citada) e a volubilidade contida nas designações da moça, reelabora-se o mito bíblico, conserva-se o "meio dizer" - lírio - que interessa ao protagonista, no intento de restabelecer pureza e constância. Sua ligação com a Bíblia e Homero, momentos áureos da tradição literária, é refeita pela instância que organiza a narrativa. Nessa tradição, a verdade já está, de alguma forma, inscrita, cabendo-Ihe recontá-la de acordo com a própria estória e garantindo, pela reescritura, marcas pessoais e autoria. (Passos, 2000, p. 24)
}

Uma observação de Cury (2001), parece ser especialmente relevante na construção textual de "Desenredo", uma vez que o texto platônico comparece na 
obra de maneira explícita "ele queria os arquétipos, platonizava" e de maneira indireta por meio das relações de Livíria com o phármakon:

\begin{abstract}
A riqueza de relações claramente expressa no conto faz da inflexão sobre o discurso bíblico um prisma que recupera inúmeros outros. Borges, por exemplo, considera o livro de Jó como "une grande imitation en hebreu du dialogue platonicien" (Borges,1992:115), certamente devido à estrutura em diálogo do livro bíblico, dimensão que, a se prestar atenção ao prefácio, não parece ter escapado a Guimarães Rosa. (Cury, 2001, p. 101)
\end{abstract}

Para além da criação e recriação de episódios literários, na esfera linguística, Guimarães Rosa reconfigura a linguagem, desestabilizando provérbios, marcas da oralidade e as palavras, a fim de espelhar o processo de desenredar até mesmo nas unidades mínimas de sua obra.

No nível lexical, o jogo de Rosa é exemplo irrefutável dos "rearranjos" e "desarticulações", que estruturam a narrativa, de modo que sua análise pode iluminar maneiras de empreender o "desenredo", já que:

\begin{abstract}
a artimanha do namorado está em reoperar fatos pretéritos, apoiado em negaceios, desvios da lógica aristotélica, rupturas com a cronologia dos fatos, etc. E a estratégia é o manejo peculiar da palavra, o uso de expedientes verbais (prefixos de negação, por exemplo), que escamoteiam e subvertem o poder dos ditos cristalizados. (Passos, 2001, p.24)
\end{abstract}

Assim, é necessário dedicar-se à releitura dos vocábulos para buscar sua plurissignificância. Por exemplo, em "a que, nesta observação, a Jó Joaquim apareceu.", podemos considerar "apareceu" como um prefixo negativo "a" seguido do verbo parecer, uma vez que a mulher não revelou a sua natureza a Jó Joaquim. Já em: "Mas tendo tudo de ser secreto, claro, coberto de sete capas." Notamos a ambiguidade do "claro", que não é inocente, pois poderia ser anulada por uma expressão como "evidentemente". Já em "Jó Joaquim, além disso, existindo só retraído, minuciosamente.", o termo retraído já antecipa a dupla traição à qual o protagonista será submetido. Em "Expulsou-a apenas", pode-se vislumbrar a expressão "a penas, com sofrimento intrincada na conjunção. Já em "Total o transato desmanchava-se, a anterior evidência e seu nevoeiro", o prefixo "trans", como já assinalara Passos (2001), indica o além-ato e em desmanchava-se, nota-se a duplicidade entre "desfazer" a negação da mancha que maculava a imagem de Livíria.

Rosa ainda brinca com os provérbios populares, algo recorrente em sua obra e muitas vezes discutido pela crítica. Por exemplo: "num abrir e não fechar de ouvidos". ; "Vá-se a camisa, que não o dela dentro".; "A bonança nada tem a ver 
com a tempestade." Entretanto, a neologia, outra característica central em sua ficção, não aparece com tanta ênfase nesse conto:

\begin{abstract}
Um exame sumário do léxico mostra que os neologismos aqui são menos numerosos que usualmente neste autor. A recolher dois deles, ufanático (ufano+ fanático) e abusufrutos (abuso+usufrutos), criações do tipo portmanteau conforme teorização de Lewis Carroll (...) Em meio a alguns termos raros, que conforme hábito do escritor parecem de sua lavra, mas não são, temos ainda os neologismos franciscanato (por derivação simples) e abominoso (por mera troca de sufixo). Mais ousado é o sintagma no frágio da barca, onde a retrospecção à etimologia permite recompor os passos (nau+ frágio, sendo o primeiro termo substituído por seu sinônimo e ambos submetidos a radical troca de posição.) (Galvão, 1996, p. 126)
\end{abstract}

Ao analisarmos verticalmente o texto, entramos no universo do "artesão" da palavra. O primeiro parágrafo já insere o leitor no mundo da oralidade: "Do narrador a seus ouvintes" (Rosa, 2001, p. 72) sugere o que Gama (2002) denomina "simulacro da oralidade": "um início de texto sem verbos e que materializa em letras o que se quer destinado a ouvintes, cria um horizonte de leitura diverso do que o leitor está comumente acostumado." (Gama, 2002, p. 312).

A dimensão oral é organizadora na poética de Guimarães Rosa, que recorre, à forma oral, à variação linguística e aos recursos sonoros em sua escritura. Diogo (2015, p. 131), afirma que o uso de perguntas em "Desenredo" funciona como uma estratégia discursiva para segurar a audiência típica da oralidade. Outra marca do mundo da oralidade foi apontada por Verri (2006, p. 05), a presença de uma voz narrativa que conta sem defender a veracidade dos fatos, como em "Diz-se também que de leve a ferira" e em "o marido faleceu, afogado ou de tifo". Segundo ela: "São registros bastante característicos dos casos transmitidos de um contador ao outro apenas por meio da fala em que o narrador não demonstra certeza em relação àquilo que conta, por saber que existe aí a intervenção pessoal de cada contador." (Verri, 2006, p. 05)

Esse é mais um âmbito no qual "Desenredo" procura desestabilizar a narrativa tradicional:

- Jó Joaquim, cliente, era quieto, respeitado, bom como o cheiro de cerveja. Tinha o para não ser célebre. Com elas quem pode, porém? Foi Adão dormir e Eva nascer. Chamando-se Livíria, Rivília ou Irlívia, a que, nesta observação, a Jó Joaquim apareceu. (Rosa, 2001, p. 72)

A presença do travessão nesse parágrafo reforça o "simulacro da oralidade", contudo essa descrição inicial é caracterizada, sobretudo, pela escassez de verbos e pela descrição de Jó - avessa à expectativa do leitor quanto ao protagonista de 
uma estória de amor. A narrativa é estruturada por "construções à maneira de provérbios, com predominância dos verbos ser e estar no presente, acarretando generalidade e atemporalidade. (Galvão, 1996, p. 127). Além disso, a Bíblia é convocada novamente, evocando o mito de Eva - mulher fatal que expulsa o homem do paraíso - assim como Livíria expulsa Jó de sua pacata quietude. Contudo, o que mais salta aos olhos é a tripla denominação da mulher. Segundo Vera Novis essa nomeação se deve ao seguinte fato:

Livíria remete a Lívia e retoma a imagem de lírio, símbolo da pureza do feminino. Rivília traz à lembrança a imagem de rio, simultaneamente curso d'água e curso do tempo, e também de ilha. Irlívia remete a Irlanda, evidentemente não como espaço geográfico real, mas como referência ao espaço mítico poético no qual Joyce fez circular sua mulher-rio.(Novis, 1989, p. 131)

Contudo, na presente análise a ligação Guimarães-Joyce não se configura como o fio condutor. Temos aqui uma descendente de Eva, isto é, uma mulher inserida na tradição das mulheres fatais e (por que não?) das tecelãs fatais. Segundo o dicionário de mitos de Brunel, as tecelãs: "Serão santas ou feiticeiras; no Delfinado serão mulheres de vida desregrada." (Brunel, 2005, p.374), de modo que elas igualmente conduzem "o fio do desejo" (Brunel, 2005, p. 379). Circe, Calipso, Helena são tecelãs, mas diametralmente opostas à Penélope homérica. Livíria insere-se nessa tradição de anti-penélopes, enquanto Jó Joaquim representa o paradigma da fidelidade, uma versão masculina de Penélope.

A figura de Penélope é resgatada em "Desenredo" devido ao movimento de fazer e desfazer de Jó Joaquim, contudo também cintila igualmente em Livíria. Conforme discutido na introdução teórica, até mesmo a mais fiel das mulheres, horizonte de sensatez, traz uma dose de ambiguidade ao construir o ardil do tear.

Lembramos que a astúcia de Penélope não está na tessitura em si, uma vez que a tecelagem pertence à esfera do que é esperado da mulher grega virtuosa. $O$ que instala a transgressão de Penélope e a recuperação do próprio destino é o desmanchar da trama e consequentemente o desenredar-se da previsibilidade. Ao manipular os fios de maneira contrária à norma, ela assume o fio da sua história e passa a decidir o seu futuro. Além de passar a protagonizar as suas escolhas, Penélope, por meio da métis, instala-se como narradora-aedo dentro do poema, já que altera a temporalidade da sua história e dos pretendentes, bem como seu desfecho. Ao recorrer ao artifício da mortalha de Laerte para ludibriar os pretendentes e postergar um potencial casamento, a protagonista cria uma ficção e, 
portanto, faz-se narradora: "Isso faz de suas palavras para [os pretendentes] uma instância da capacidade das Musas de tecer pseudea homoia etumoisin - "coisas falsas em coisas verdadeiras"- sempre que elas desejam (Bergren, 2008, p. 04, tradução nossa)" ${ }^{54}$. Assim, na trama de Penélope a fim de manter-se fiel à Ulisses, os fios do tear e os fios discursivos são complementares para o sucesso da empreitada: é preciso urdir um simulacro convincente com os fios do discurso e, paralelamente, destecer os fios empíricos com o intento de defender a autonomia do oikos e a memória de Ulisses.

Desse modo, é possível afirmar que Penélope cria um engodo e, portanto, uma ficção tecendo. Jó Joaquim recorre a esse mesmo expediente calcado na métis para ludibriar a cidade e recuperar a imagem de Livíria, porém tanto o tecer quanto o destecer de Jó encontram-se na esfera discursiva: ele urde para a mulher uma imagem imaculada, enquanto destece suas traições.

A dimensão da tessitura é também enfatizada pela escolha lexical, desde o próprio título, que invoca a trama, e aos ecos de imagens relativas à costura no momento em que o narrador descreve a refatura da história por Jó Joaquim. Quase podemos ver Jó sentado à maquina de costura remendando os testemunhos, cortando os nós e operando com agulhas o próprio destino:

O ponto está em que o soube, de tal arte: por antipesquisas, acronologia miúda, conversinhas escudadas, remendados testemunhos. Jó Joaquim, genial, operava o passado - plástico e contraditório rascunho. Criava nova, transformada realidade, mais alta. Mais certa?

A tripla denominação de Livíria remete aos estudos psicanalíticos, nos quais Freud analisa uma série de tríades de mulheres, em que a terceira é a mulher exímia: "Contentemo-nos com Cordélia, Afrodite, Cinderela e Psique. Em todas as histórias, as três mulheres, das quais a terceira é a mais excelsa, devem seguramente ser encaradas como de certo modo semelhantes." (Freud, 1990, p. 370). Se as mulheres citadas são três sujeitos distintos, em "Desenredo" a natureza da mulher é tripartida: Livíria, Rivília e Irlívia, além de uma quarta face oculta que será abordada em outro momento.

Se não esquecermos que em um conto todos os elementos são significativos devido a máxima concentração do 'gênero', poderemos observar que a ordem da

\footnotetext{
54 "It makes her words to them an instante of the Muse's capacity to utter pseudea homoia etumoisin "false things to real things", whenever they wish. (Bergren, 2008, p. 04)
} 
nomeação da protagonista é extremamente significativa: no segundo nome, Rivília, está presente a potência vil, que será retomada em Vilíria. Como a "potência vil" encontra-se na sílaba central do nome do meio, citado por Rosa, pode-se pensar que o ponto central de Livíria, revestida nas extremidades pela pureza do lírio: Livíria e Irlívia, que mascaram a sua vilania. ${ }^{55}$

Ainda observando a onomástica da personagem, se atentarmos para a terminação dos três nomes encontraremos as formas verbais ria (Livíria), lia (Rivília) e via (Irlívia). Esses verbos são repetidos ao longo de todo o conto, espelhando o jogo entre boca, olhos e palavra que estrutura a sedução e a criação literária. A sedução dá-se primeiramente pelo riso, e só por último pela troca de olhares "Sorriram-se, Viram-se", já o verbo ler é central na relação do casal já que o autor-poeta Jó Joaquim para conseguir reescrever a mulher-palavra Livíria deverá valer-se da leitura, tanto da situação quanto da tradição literária a fim de alterar o estatuto da amada na comunidade. No âmbito da criação literária, ao considerarmos o conto um simulacro do conto oral, a importância entre ler/ver/rir intensifica-se, uma vez que a dimensão da performance é característica inerente do "gênero".

O nome da protagonista ainda pode ser interpretado por outro viés: "Nos nomes Livíria ou Irlívia ou Rilívia ou Vilíria, os componentes materiais da palavra enfocam o movimento referido anteriormente, o ir e vir da personagem potencialmente expresso no signo do nome próprio: LiVIRia - RilívIA - IRlívIA - VilíRIA. (Silva e Mangueira, 2012, p. 196). Essa dimensão de movimento e deslocamento, muito contribui para a análise da personagem que é móvel e se desloca nas posições de esposa e amante, além de ser afastada da narrativa pela expulsão do marido e de viajar para "desconhecido destino".

Os nomes de Jó e de Livíria, portanto, não são fortuitos, como nada na obra rosiana o é. $\mathrm{O}$ nome próprio contém paralelamente sentidos cifrados em sua divisão mórfica, em sua dimensão intertextual e em forma de anagrama, sem que necessariamente um sentido se sobreponha aos demais.

Conforme já percebera Ana Maria Machado em seu estudo acerca da onomástica em Corpo de Baile intitulado, O Recado do Nome (2003): "Através da metáfora e da sinestesia, os próprios elementos fônicos se dilatam, se incham e

\footnotetext{
${ }^{55}$ O mesmo ocorre com a protagonista do conto "Circe", de Julio Cortázar,- Délia recheia seus bombons com baratas e camufla o horror com a doçura, retomando a linhagem de Pandora - primeira mulher de muitos dons, cuja beleza era um artifício, um disfarce para a sua capacidade de dissimular e seduzir.
} 
remetem a outros significantes que, por sua vez, levam a outros ainda, num jogo de espelhos que às vezes vai quase até a vertigem." (Machado, 2003, p. 45)

Além disso, Machado recupera Lévi-Strauss para afirmar que "Os nomes próprios são propriedades do clã e guardados com ciúme" (Lévi-Strauss APUD Machado, 2003, p. 27) e, portanto, "O grupo autor do Nome tem autoridade sobre seu portador. E, se a autoria leva à autoridade, esta, por sua vez, coincide com a propriedade." (Machado, 2003, p. 27). Assim, a múltipla nomeação de Livíria, pode indicar o quanto a personagem é dona de si. A mutabilidade em sua onomástica demostra que é impossível tomá-la enquanto propriedade, uma vez que a personagem é vaporosa e instável como a própria liberdade o é.

E, ainda, se Jó Joaquim configura-se no papel de autor da própria estória, Livíria representa a mulher-palavra: "Enquanto ficcionalização do leitor e de um modo de leitura, Jó Joaquim é aquele que é enredado por um texto complexo como Livíria." (Gama, 2002, p. 322). Nesse sentido, Livíria é phármakon, no sentido platônico do termo, isto é, enquanto palavra, Lívíria é cura, veneno e maquiagem; três nomes, três dimensões do phármakon a serem contempladas . É tanto "o aroma" de Jó Joaquim, seu "ar que vem do ar" - portanto cura, quanto aquela que o leva ao "decúbito dorsal", seu veneno. E, sobretudo, maquiagem, ao ter ao menos quatro faces, quatro máscaras ao longo da narrativa: Livíria, Rivília, Irlívia e Vilíria. Em "A Farmácia de Platão" (2005), Derrida retoma o Fedro platônico, a fim de esmiuçar os sentidos do phármakon e sua relação com a palavra. Sua descrição da ambivalência benéfica e maléfica do phármakon se adequa à mulher-palavra Livíria:

\footnotetext{
Esse phármakon, essa "medicina", esse filtro, ao mesmo tempo remédio e veneno, já se introduz no corpo do discurso com toda sua ambivalência. Esse encanto, essa virtude de fascinação, essa potência de feitiço podem ser - alternada ou simultaneamente- benéficas e maléficas. (Derrida, 2005, pp. 15, 16)
}

Livíria é a palavra, pois sem ela não há enredo ou desenredo, é a partir do encontro com Livíria que há material narrativo. Enquanto palavra, a mulher é opaca (Bosi, 2010, p.461), portanto plurissignificativa e inapreensível em sua totalidade, e é por isso que Jó Joaquim consegue redimi-la, pois altera a materialidade e plasticidade da palavra-Livíria e da palavra-enredo. Segundo Isolan, "não só Jó Joaquim é traído, mas também a relação palavra-texto." (Izolan, 2009, p. 9). Jó Joaquim e Livíria vão, portanto, espelhar, por meio do adultério de Livíria, a “adulteração” (Izolan, 2009) das palavras e do enredo operada por Rosa. 
Além disso, a semelhança fonética pode nos levar a associar Livíria à Lírica, dimensão poética permeada pela metáfora, pela inversão, pelos ardis de versos e rimas. Ainda se pode notar, como a crítica já assinalou, a possibilidade de aproximar Líviria das musas, umas vez que é ela que inspira a reescritura empreendida por Jó Joaquim e the confere os elementos para tornar-se autor.

A mulher põe em cena a ambiguidade da palavra poética e sua atmosfera de phármakon. Livíria é passível de ser operada e adulterada tal como a palavra poética, pois os discursos que circundam a personagem pertencem ao mundo da oralidade. $\mathrm{O}$ ardil discursivo de Jó Joaquim desconstrói a voz da aldeia e da coletividade, a fim de cristalizar a sua Livíria arquetípica "em ata", certeza de permanência.

\footnotetext{
Antes bonita, olhos de viva mosca, morena mel e pão. Aliás, casada. Sorriram-se, viram-se. Era infinitamente maio e Jó Joaquim pegou o amor. Enfim, entenderam-se. Voando o mais em ímpeto de nau tangida a vela e vento. Mas tendo tudo de ser secreto, claro, coberto de sete capas. (Rosa, 2001, p. 72)
}

Vale observar de perto a descrição das personagens. Conforme já notara Mônica Gama (2002), Jó Joaquim é descrito por suas características éticas, enquanto Livíria recebe apenas a caracterização física, de modo que "O leitor é compelido a preencher as lacunas das características físicas de Jó Joaquim, por um lado, e, por outro, das posições éticas de Livíria." (Gama, 2002, p. 317). Faz-se necessário ressaltar, entretanto, a ordenação das descrições que oscilam da parte ao todo, primando pelo detalhe.

A beleza de Livíria, sintetizada nos olhos e na pele antecedem a sua função social de esposa, pois a sedução, exercida por meio da beleza é o ponto focal da personagem. Mesmo na sua descrição física é possível perceber que Livíria é uma mulher mais próxima do prazer, do divino: "morena mel e pão", a doçura do mel, alimento próximo da ambrosia dos deuses, antecede o pão fabricado pelo homem e sinal de reconhecimento entre eles.

O mel ainda traz uma dimensão viscosa, que será redobrada em "grude de engodos, e sua doçura atrairá as "formiguinhas brancas" das lágrimas de Jó Joaquim, enredando-o numa teia pegajosa de sedução. Destaca-se ainda as propriedades naturais do mel, produzido pelas abelhas, atraídas pelo aroma das flores ("ela era um aroma"). É uma das poucas substâncias na natureza que sofre cristalização e retorna ao estado líquido após o banho-maria sem perder suas 
propriedades, movimento que parece reger a trajetória de Livíria: cristalizada enquanto traidora na boca da aldeia deve ser levada para longe, para que, à distância, possa ser remoldada pelo poder da água. Nota-se que a expressão "em banho-maria" sugere a suspensão do enlace amoroso, que não assume forma decisiva.

A mesma lógica vale para o sorriso que antecede o olhar, isto é, a sedução antecede a leitura da alma, de modo que, desde a situação de equilíbrio do conto, Jó está sendo enredado nos ardis de Livíria, que desvia seu foco da norma, envolvendo-o em sua aparência encantadora. O olhar terá um papel central na narrativa, uma vez que:

Desenredo" ainda pode ser lido como uma aprendizagem do olhar: Jó
Joaquim redireciona seu olhar para o que lhe falta - a mulher - e não para o
que é a realidade palpável a sua comunidade - homem traído.
Reaprendendo a olhar, Jó Joaquim reaprende o caminho do amor e, por
extensão, se reconstrói a partir da desconstrução de um enredo não tão
feliz. (Diogo, 2015, p. 132)

O amor é tratado por Guimarães conforme a concepção da Grécia Arcaica: "Jó Joaquim pegou o amor", patologia do amor reatualizada, pois a concepção grega do amor era a de Eros destruidor de membros, isto é, de um amor que se impunha sobre o amante de fora para dentro. Já as referências náuticas ("nau tangida a vela e vento"; "todo abismo é navegável a barquinhos de papel", "naufrágio" derivado de frágio da barca; Até que deu-se o desmastreio funcionam como ecos de Ulisses, como as críticas Vera Novis (1989) e Walnice Galvão (1996) já haviam ressaltado.

Para além desse fato, a recorrência de elementos aquáticos ${ }^{56}$ instaura uma isotopia no conto, que está associada à limpeza da aura de Livíria. A água configurase como símbolo por excelência da pureza e um locus de transformação. O Dicionário de Símbolos de Gheerbrant e Chevalier (1994, pp. 15-22) nos lembra que a água exerce três papéis fundadores que se espraiam em culturas de todo o globo: A ambivalência vida e morte; a purificação e a fertilidade. Ainda que o dicionário possa generalizar alguns aspectos, é patente que a força da água como elemento de purificação recobre culturas diversas, a guisa de exemplo, veja-se o batismo cristão e o banho sagrado no Ganges hindu.

\footnotetext{
${ }^{56}$ ("O trágico não vem a conta-gotas."; "o marido faleceu, afogado ou de tifo"; "Suas lágrimas corriam atrás dela, como formiguinhas brancas."; "A bonança nada tem a ver com a tempestade." ; "o que fora tão claro como água suja."; "o tempo secou o assunto", Total o transato desmanchava-se, a anterior evidência e seu nevoeiro")
} 
A água será um dos estruturadores da narrativa, já que, enquanto elemento fluido, pode ser moldado e pode esconder em sua profundidade e mutabilidade o que "fora tão claro como água suja". Ao final do processo de purificação, o tempo seca o assunto e desmancha o nevoeiro (água em estado gasoso), para se fixar na estabilidade da terra, a árvore que vai para cima. Cessa a travessia. Cessa o ziguezaguear da odisseia. A nau atraca em Ítaca e troca a mobilidade líquida da oralidade pela firmeza terrestre do papel. $O$ elemento ar também soprará no conto, tangendo a nau em meio à água, insuflando a tempestade, espalhando cheiro de cerveja e aroma de Lírio, desmanchando nevoeiros, soprando em "dengos e fofos de bandeira ao vento". Esse tom volátil, dado pela recorrência de figuras relacionadas ao ar, enfatiza a natureza volátil e inapreensível de Livíria.

O tema da espera é resgatado textualmente na estória: Esperar é reconhecerse incompleto. (Rosa, 2001, p. 73), reafirmando o paralelo Jó Joaquim/ Penélope. Contudo, até esse momento o texto está em equilíbrio, estamos diante de um triângulo amoroso tradicional, comum na literatura ocidental. É a expressão "Até que deu-se o desmastreio que rompe a linearidade textual e inaugura a subversão: "Até que - deu-se o desmastreio. $O$ trágico não vem a conta-gotas. Apanhara o marido a mulher: com outro, um terceiro... Sem mais cá nem mais lá, mediante revólver, assustou-a e matou-o. (Rosa, 2001, p. 73)

O duplo adultério de Livíria rompe a lógica tradicional do enredo e reduz Jó Joaquim à categoria de "pseudopersonagem", já que não cabe a ele nem o papel de marido nem o papel do amante. Uma vez que estamos em diálogo com a Grécia, vale relembrar que o herói grego, grupo ao qual pertence Ulisses (explicitamente citado no conto) é aquele que obtém excelência nas armas e nas palavras. Nesse sentido é válido ressaltar que o fragmento evoca o fato de o marido de Livíria em "Desenredo" ser um homem das armas - resolvendo os seus problemas através da força física - enquanto é possível depreender do desenvolvimento do conto que Jó Joaquim é um homem das palavras, isto é, altera o seu destino textualmente. E é a morte do então marido valente que irá provocar outra reviravolta no texto:

Soube-o logo Jó Joaquim, em seu franciscanato, dolorido mas já medicado. Vai, pois, com a amada se encontrou - ela sutil como uma colher de chá, grude de engodos, o firme fascínio. Nela acreditou, num abrir e não fechar de ouvidos. Daí, de repente, casaram-se. (...)

Mas.

Sempre vem imprevisível o abominoso? Ou: os tempos se seguem e parafraseiam-se. Deu-se a entrada dos demônios. (Rosa, 2001, p. 74) 
Nesse momento da narrativa, Jó Joaquim assume o papel de marido, sem contar com a repetição do adultério. Contudo, o comportamento de Livíria é cíclico e, portanto, a traição é reincidente. A conjunção adversativa "mas", ao constituir um parágrafo, marca uma cisão na estória, o impedimento da felicidade "ideia inata", isto é, mais uma quebra de expectativa para Jó, que esperava um casamento arquetípico, e do leitor, que esperava uma estória tradicional.

Além disso, o aforismo "Os tempos se seguem e parafraseiam-se" destacado do excerto pode ser considerado uma síntese do procedimento poético da construção do texto. A reatualização de temas da literatura universal (adultério, criação poética), expressos pela noção de paráfrase, entrelaça-se com a visão de um momento literário específico. Essa relação permite que a luz lançada sobre essas mesmas questões literárias seja distinta tanto no âmbito da linguagem quanto da própria construção do enredo, pois o momento histórico "se segue", altera-se.

\footnotetext{
Expulsou-a apenas, apostrofando-se, como inédito poeta e homem. E viajou a mulher, a desconhecido destino.

Tudo aplaudiu e reprovou o povo, repartido. Pelo fato, Jó Joaquim sentiu-se histórico, quase criminoso, reincidente (...) Dedicou-se a endireitar-se.

(Rosa, 2001, p. 74)
}

A postura de Jó Joaquim difere da do primeiro marido, já que Jó é um homem das letras e, portanto, "não era para truz de tigre ou leão". Ele não fere a esposa, apenas a expulsa do espaço sagrado do lar, agindo para além de personagem: "apostrofando-se, como inédito poeta e homem". A reação do povo, da aldeia, "a alheia vigilância", é importante no conto, pois marca a memória coletiva e a voz popular, que também terá que ser reescrita para que o "Desenredo" tenha êxito. Após a segunda traição, Jó Joaquim, antes quieto e nada célebre passa a ser alvo da atenção popular, a crítica de sua estória.

A presença textual do verbo "viajar" reforça a aproximação com o ciclo de poemas homéricos, uma vez que a mulher assume o papel do aventureiro e navegador, viajando a desconhecido destino; enquanto Jó Joaquim espera em sua incompletude o reencontro, destecendo os discursos e fatos que poderiam impedir a reaproximação. Além disso, Livíria, ao partir, resguarda-se dos olhares do povoado. Em seguida, vale ressaltar que o narrador afirma que Jó Joaquim "Dedicou-se a endireitar-se", o que vemos no seguir do conto, entretanto, é que Jó dedica-se a endireitá-la, a Livíria, promovendo a ruptura da lógica canônica do enredo. 
Além disso, o eco do campo do direito subjaz ao vocábulo, uma vez que Jó Joaquim passa a ser advogado da mulher, ao manipular o real em prol de sua inocência diante de um júri popular encarnado pela aldeia. A voz da narrativa, entretanto, não emite nenhum julgamento acerca da postura de Livíria, o único juízo é depreendido pela reação da coletividade e cabe ao leitor avaliar a mulherphármakon: "Há um ponto a ser discutido sobre a conduta da mulher. Entretanto não há no texto a resposta para a questão. Este julgamento fica a cargo do leitor, que pode refletir e questionar como lhe convier. Não há, no texto um juízo de valor expresso sobre o assunto. (Verri, 2006, p. 05)

Mais.

No decorrer e comenos, Jó Joaquim entrou sensível a aplicar-se, a progressivo, jeitoso afã. A bonança nada tem a ver com a tempestade. Crível? Sábio sempre foi Ulisses, que começou por se fazer de louco. Desejava ele, Jó Joaquim, a felicidade idéia inata. Entregou-se a remir, redimir a mulher, à conta inteira. Incrível? É de notar que o ar vem do ar. De sofrer e amar, a gente não se desafaz. Ele queria os arquétipos, platonizava. Ela era um aroma.

Nunca tivera ela amantes! Não um. Não dois. Disse-se e dizia isso Jó Joaquim.

Reportava a lenda a embustes, falsas lérias escabrosas

(Rosa, 2001, p. 74)

A expressão aditiva "mais" marca esse momento em que o protagonista decide alterar a visão popular acerca da esposa. A referência explícita à personagem Ulisses confirma a nossa hipótese de intertextualidade entre Odisseia e "Desenredo" e demonstra que, além de ser o Penélope, Jó também absorve traços do "melhor dos aqueus", uma vez que Ulisses configura-se como o herói da resistência. Jó também resiste à realidade operando o passado com o seu platonismo para obter uma mulher arquetípica:

\footnotetext{
Nesse sentido, ele figura o artista que tem o poder de criar "nova, transformada realidade" a partir dos elementos da realidade factual e lidando, ao mesmo tempo, com os modelos literários. "Ele queria apenas os arquétipos, platonizava. Ela era um aroma" Jó Joaquim, não mais como personagem e sim como autor, recria a personagem feminina, Livíria, segundo seus arquétipos literários. (Novis, 1989, p, 135)
}

Contudo, ao aspirar a uma Penélope, paradigma da fidelidade conjugal e excelência feminina, pode-se esquecer de que há outros arquétipos femininos nos poemas homéricos, a filha de Eva, em cuja linhagem encaixam-se Helena de Troia, Circe, Calipso e, por analogia, Livíria.

Por outro lado, a aproximação de Jó e Ulisses por meio do episódio da loucura de Ulisses também reforça a dimensão performática das ações de Jó. Esse 
episódio, pertencente ao ciclo homérico mas não narrado na Odisseia conta que Ulisses, ao receber a notícia de que seria enviado à Guerra de Tróia e que teria que deixar a amada esposa Penélope e o filho pequeno, usa a sua inteligência astuciosa para fingir-se de louco a fim de permanecer ao lado mulher. Essa atitude poderia afetar decisivamente a visão que a coletividade teria do herói, mas Ulisses opta por comprometer essa imagem para evitar a separação. Jó Joaquim parece ter uma atitude semelhante, em um primeiro momento finge e dissimula acerca da pureza da esposa para poder ficar ao seu lado, correndo o risco de ser considerado louco e fomentar o "feliz escândalo popular". 57

Pois produziu efeito. Surtiu bem. Sumiram-se os pontos das reticências, o tempo secou o assunto. Total o transato desmanchava-se, a anterior evidência e seu nevoeiro. O real e válido, na árvore, é a reta que vai para cima. Todos já acreditavam. Jó Joaquim primeiro que todos. (Rosa, 2001, p. 75)

Esse parágrafo comprova o êxito do "desenredo" empreendido por Jó, que convence a si mesmo e à coletividade da sua ficção (e porque não fiação), colocando-se como autor de sua própria história. Se "sumiram-se os pontos das reticências", é porque Jó foi capaz de moldar seu destino e redesenhar seu casamento, já que as únicas reticências que aparecem no conto são as destacadas no excerto: Apanhara o marido a mulher: com outro, um terceiro...”.

A pontuação no fragmento tanto alude aos três homens; Jó Joaquim, o marido e o amante; quanto a tripartição de Jó que "começa amante, acreditando-se ingenuamente único, depois, transforma-se em marido enganado e, por último, em companheiro feliz. (Passos, 2000, p. 24). Contudo, as reticências apontam, sobretudo, para a ideia de continuidade e inexatidão, sugerindo que o adultério não se restringe aos três homens; na suspensão reticente cabem todos os amantes que se envolveram na trama têxtil e textual de Livíria, só interrompida no instante em que somem os pontos das reticências que cedem espaço a assertiva concretude do ponto final.

Após convencer a si mesmo e à coletividade da transformação de Livíria, pode revelar à esposa a sua imagem purificada em que o adultério é transmutado em castidade:

\footnotetext{
${ }^{57}$ Cf Aristóteles Arte Poética, Capítulo VIII . Tal episódio não pertence à Ilíada nem a Odisseia, mas foi narrado nos, no fragmento I das Cíprias ou cantos Cípricos, assim como o julgamento de Páris. Esse poema pertence ao Ciclo Épico ao qual tivemos acesso apenas a alguns fragmentos. Cf. http://www.theoi.com/Text/EpicCycle.html
} 
Soube-se nua e pura. Veio sem culpa. Voltou, com dengos e fofos de bandeira ao vento.

Três vezes passa perto da gente a felicidade. Jó Joaquim e Vilíria retomaram-se, e conviveram, convolados, o verdadeiro e melhor de sua útil vida. (Rosa, 2001, p. 75)

O nome Vilíria, revelado no final do conto, escancara o traço vil de Livíria, porém adoçada pela pretensa pureza: "Vilíria, simultaneamente vil e lírio, oxímoro perfeito" (Novis, 1989, p. 134). Na esteira da crítica, a nova identidade se faz necessária pois uma nova mulher foi criada pelas agulhas hábeis de Jó Joaquim, as letras embaralham-se, mas os elementos inicias se estabilizam de modo que o passado não é apagado e sim recriado. ${ }^{58}$

Além disso, no desfecho "o texto, que antes só comportava um final triste ou feliz (estrutura do enredo tradicional) passa agora a apontar algo de outra ordem." (Izolan, 2009, p. 11). Na esteira do pensamento de Izolan podemos concluir que a negação da estrutura binária (feliz/triste), isto é, a ambivalência do desfecho, é fruto da ambivalência da protagonista feminina, que comporta muitas facetas, de modo que resta ao leitor a dúvida e quase a desconfiança de que a traição se repetirá.

O conto, cuja atmosfera é marcada pela atemporalidade, resgata a poética do mito, a fim de se ancorar na estrutura fabular, textualmente resgatada. Essa dimensão invoca o arcaísmo do mito, figurada em um uso da linguagem extremamente moderno empreendido por Rosa. Dessa maneira, conforme já discutido pela crítica, o moderno e o arcaico coexistem, na modernidade da linguagem e no arcaísmo dos temas e valores que sustentam o sertão rosiano. Seu arcaísmo intrínseco aparece na configuração social: a pequena aldeia é a eterna vigilância dos comportamentos e quer regular os corpos e mentes. Livíria, ao transgredir a ordem retrógrada, é ameaçada e deve fugir para longe, só sendo possível sua reabilitação por meio da interferência de uma voz masculina.

Outro traço marcante da poética do mito em "Desenredo" é a presença da repetição e da metáfora, já amplamente abordadas na análise. Em Rosa, até mesmo a formulação assertiva, característica da estrutura mítica, pode ser percebida no uso de aforismos e na reelaboração de provérbios populares que transmitem verdades universais. A última frase do conto encerra o simulacro de oralidade - outro traço central da poética mítica - empreendido em sua primeira linha: "E pôs-se a fábula em ata." (Rosa, 2001, p. 75), "Da oralidade fabular passa-se à ata, isto é, da fugaz

\footnotetext{
${ }^{58}$ Ver entre outros (Gama, 2002, p. 318)
} 
memória popular - rasurada e transfigurada - à autoridade da letra, matéria concreta e testemunho mnemônico para sempre registrado, sem reticências ou desconfianças." (Passos, 2001, p.24).

O discurso móvel da fala precisa ser cristalizado em palavra gráfica a fim de que o "nevoeiro" seja totalmente dissipado e a memória fixada. Ao escolher uma voz para guiar o texto, apagam-se os múltiplos ecos da aldeia. O primeiro a acreditar no simulacro convence a todos da "verdade" inventada, que ao ser papel, torna-se a única e irrefutável. A épica também passou por esse processo: do mundo da oralidade das canções dos aedos, primeiros transmissores dos poemas homéricos, passou-se à fixação dos textos em livros na biblioteca de Alexandria - o nevoeiro da fala e sua instabilidade imobilizado na concretude estática do papel:

\begin{abstract}
A apropriação do final de "Desenredo" é das mais oportunas para a suspensão das tramas sobre o feminino aqui apontadas; da oralidade à ata, as fabulações permitem redes contínuas de inesgotáveis leituras... Se o conto sugere que a verdade tem estrutura de ficção" (Lacan, J. Le semináire, livre VII, p. 22), também a filia à história literária. O épico e o lírico comparecem tanto na alusão bíblica a Jó, quanto na citação explícita de Ulisses a evocar Penélope, sua fidelidade e engenhosa tessitura. $O$ protagonista se insere numa tradição em que a "verdade" já está, de alguma forma, inscrita, cabendo-lhe recontá-la de acordo com a própria estória e garantindo, mediante reescritura do narrador, marcas pessoais e autoria. (Passos, 2000, p. 223)
\end{abstract}

Outra dimensão fulcral no conto rosiano é a metalinguística. Não é por coincidência que Rosa estrutura sua estória a partir dos elementos composicionais da narrativa: enredo, personagem, tempo, espaço e narrador aparecem como norteadores da trama de Jó Joaquim, ainda que camuflados na intriga dos namorados:

\author{
Des-enredo \\ Recusava-se a ser pseudo-personagem \\ O tempo é plástico/ $O$ tempo é engenhoso \\ As aldeias são a eterna vigilância \\ Do narrador a seus ouvintes
}

No conto, portanto, testemunhamos a tessitura de uma narrativa, acompanhando os embates e rearranjos do autor na tentativa de lapidar uma personagem que retome e transcenda os arquétipos. Paralelamente, vemos como a criação foge do controle do autor que precisa fazer e refazer o tecido do texto com o intuito de ajustar os pontos da trama: 
Em "Desenredo", somos testemunhas de uma busca radical, que se manifesta na inquietude que acompanha o escritor na fatura de sua obra, ali "onde Beleza e Verdade se encontram". Trata-se do amor à palavra em busca de uma forma que lhe traduza sentidos, a cada vez por uma expressão única, por uma forma singular, na sua mais radical verdade, ainda que transitória. (Montagna, 2011, p. 06)

Guimarães Rosa ministra em seu "Desenredo" uma aula magistral acerca da teoria da narrativa e de como elaborar um conto que fuja às armadilhas do senso comum. O cuidado na escolha e no entrelaçamento das palavras e imagens, o encaixe da trama, a disposição das imagens, assemelham-se ao cuidado da bordadeira com os seus bastidores, fios e agulhas. Rosa nos revela que a palavra deve ser operada e reelaborada a fim de criar uma nova estória, que não repita o já dito, mas que seja capaz de reelaborar a tradição, enredando o leitor em encantamento e convocando-o para desvelar o texto:

Desenrolando o fio da linguagem poética, movido pelo desejo, o artista entrega-se ao trabalho imaginativo paciente, minucioso, para poder encontrar uma linguagem inédita. E nessa direção desempenha um papel fundamental de ponte entre a tradição e sua arte transformadora. Testemunhamos, assim, a forja do conto, a luta entre as personagens, os embates do poeta para conseguir estabelecer um diálogo interno fértil consigo mesmo, com as experiências acumuladas, para encontrar saídas inusitadas, e quem sabe superar contradições. (Montagna, 2011, p. 04)

“Desenredo", portanto, pode fazer parte do testamento estético do autor e uma declaração de amor à escritura, ao trabalho poético, que com seus fios-palavra enlaça as linhas da palma de nossas mãos e torna a existência mais tolerável, mais humana e permeada de sentido.

\subsection{Sóis de Sedução, Alquimia de Enganos}

Ela não sua. Seus sumos tem outra razão. Olha o relógio. O homem estará quase chegando.

Então, abrindo os braços e empinando de leve o abdômen, ela se lançará para tomar posse da sua caça, pesa pela elástica seda que o seu corpo fia, e que a mantém suspensa em lenta descida.

(Marina Colasanti)

A outra narrativa rosiana que aqui merece leitura é "A Vela ao Diabo", também da obra Tutameia (2001). Aí, temos o protagonista Terezinho dividido entre as cartas da noiva Zidica, que o aguarda bordando seu enxoval, e as teias encantatórias de Dlena, amiga de diversões. 
A estória inicia-se com a personagem Teresinho, que está longe de sua amada Zidica, deslocada para São Luis onde borda o enxoval. A conexão entre os namorados é mantida pela troca de cartas, contudo, quando o conto começa, Teresinho está decepcionado, pois sente um desânimo crescente na escrita de Zidica: "Via espaçarem-se, e menos meigas, as cartas da noiva, Zidica, ameninhamente ficada em São Luís. As mulheres sóis de enganos." (Rosa, 2001, p. 50). A dimensão da palavra será de fundamental importância, não só pela troca de cartas entre os enamorados, mas também pelo meio escolhido por Teresinho com o objetivo de se reaproximar de Zidica: rezar uma novena endereçada a um santo desconhecido:

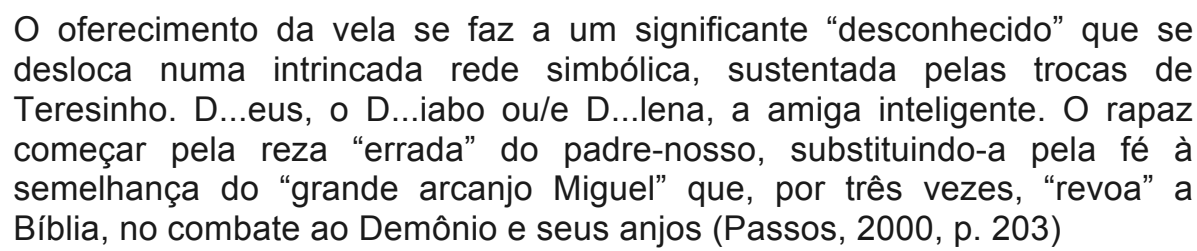

Porém, enquanto a novena se desenrola, o noivo se aproxima de Dlena, amiga disponível e terna, disposta a apoiá-lo perante a distância da noiva. Dlena vai pouco a pouco participando ativamente da vida de Teresinho, enquanto passa a minar discursivamente o relacionamento dele com Zidica. Ao fim da novena, Teresinho parece estar enfeitiçado por Dlena, entretanto, um deslize da moça que ri "rancordiosa" ao rasgar uma carta de Zidica faz com que Teresinho abra os olhos e retorne para a segurança do amor de Zidica e que vivam "felizes e infelizes misturadamente".

Para além da escritura das cartas, outros índices relativos à palavra permeiam o texto ${ }^{59}$ : Dlena, por exemplo lê as cartas e critica os erros gramaticais de Zidica, a reza pode ser considerada uma aparição da palavra-performance e a tentativa de sedução de Dlena também será operada via palavra. Em suma, a palavra aparecerá como em "Desenredo"(2001) ora como veneno - por meio dos filtros sedutores de Dlena- e ora enquanto cura - por meio das cartas de resgate de Zidica.

O título da obra também resgara a dimensão do "rearranjo" (Passos, 2001), uma vez que se configura como uma reelaboração do provérbio popular: "Acender uma vela a Deus e outra ao Diabo", e pode aludir à oposição Zidica - Dlena, e à

\footnotetext{
59 "já as coisas rabiscavam-se" (Rosa, 2001, p. 50); o "picadinho de conversa" de Dlena (Rosa, 2001, p. 51); Zidica que "desconversas escrevera, volúvel, vaga." (Rosa, 2001, p. 52).
} 
posição de Teresinho, cuja atenção se divide entre as duas moças. Além disso, "vela" poder ser interpretado como flexão do verbo "velar", mostrando a dimensão do zelo e do cuidado que aparentemente Dlena nutre por Teresinho: "Vela" pode ser substantivo, mas também terceira pessoa do tempo presente do modo indicativo do verbo velar, que, segundo Houaiss e Salles (2009), possui duas acepções básicas: (1) permanecer em vigília, zelar, proteger; (2) cobrir com véu, encobrir, tapar, esconder." (Rodrigues e Santos, 2013, p. 355). Rosa ainda brinca com a semelhança do substantivo "vela" e da forma verbal "vê-la", fazendo com que o signo de irradie por todo o texto: "Realegrou-se, em imo, coração de fibra longa. Veio vê-la" (Rosa, 2001, p. 51); "Saiu-se - e tardara - de lá, dela, de vê-la."(Rosa, 2001, p. 53)

Pensando a ancoragem do tema das tecelãs na narrativa, Zidica aqui representa a linhagem das tecelãs sensatas, configura-se, portanto, como herdeira de Penélope. A personagem retoma a heroína grega, já que fica à espera de Teresinho bordando o seu enxoval. A íntima relação da moça com a tecelagem se apresenta não só de maneira explícita - na costura do enxoval, mas também no processo de escrita das cartas que envia ao noivo. Já discutimos a intrincada relação da caneta com a agulha, sobretudo na dimensão da escrita feminina. Ao fiar ponto a ponto seu enxoval e ao enlaçar seu noivo por meio da palavra, Zidica também está criando uma realidade, ela constrói seu futuro casamento mas malhas têxteis e textuais que produz com as mãos.

Já Dlena pode ser analisada como herdeira das tecelãs fatais ao envolver Teresinho nas malhas de sua sedução: "Dlena o acolheu, com tacto fino de aranha em jejum. Seu sorriso era um prólogo." (Rosa, 2001, p. 52). O sorriso aqui aparece como metonímia das táticas de sedução da moça, cujo bote já estava armado antes de revelar-se, conforme sugere a metáfora do sorriso-prólogo.

A moça vai pouco a pouco enredando o noivo de Zidica: "Ele, dócil à sua graça, em plástico estado de suspenso, como um bicho inclina o ouvido." (Rosa, 2001, p. 51). Nessa passagem, a imagem construída por Rosa remete à do inseto paralisado na teia de aranha, suspenso por fios plásticos. O enredamento de Dlena é feito, sobretudo, por meio da palavra falada, que instrui e aconselha Teresinho com ares de psicóloga.

Enquanto a ausência de Zidica leva Teresinho ao sofrimento, o zelo e o tempo passado com Dlena curam seu coração: "Descarregado das más suspeitas, já 
cienciado: dos poros da pele às cavidades do coração. Foi saindo do doendo." (Rosa, 2001, p. 52). A diversão experimentada ao lado da moça amenizava o sofrer de Teresinho, que encontra na amiga uma companheira ao lado de quem pode viver momentos alegres: "Valia divertir-se, furtar o tempo ao tormento - apud Dlena." (Rosa, 2001, p. 52). Desse modo a oposição Dlena - Zidica é também uma oposição presença - ausência:

\begin{abstract}
"Desamor, enfado, inconstância", atribuídos a ela [Zidica], fazem parte do mecanismo psíquico do noivo, inseguro pela distância, pelo não-ver, cujo contraponto será Dlena, sempre prestadia e à vista. À ausência: presença! A personagem-aranha o sabe, comparecendo com (fra)ternura, festa e cinema para preencher os instantes aflitivos da espera. (Passos, 2000, p. 204)
\end{abstract}

Dlena ainda deseja apagar a memória que Teresinho nutre por Zidica ao prendê-lo em sua teia de "aranha em jejum". A escolha lexical pontuada por diminutivos e advérbios de tempo e modo, parece evocar a construção silenciosa da teia de aranha, que só pode ser percebida quando a presa já está encurralada: "outrossim, pensasse às vezes um risquinho em Dlena" (Rosa, 2001, p. 51); "Voltada a Dlena, tanto quanto e tanto, caminhando sutilmente" (Rosa, 2001, p. 52); "Seu parecer provava-se sagaz tática, não há como Deus, d’ora em ora. Seu picadinho de conversa, razões para depois de amanhã.” (Rosa, 2001, p. 52); "Teresinho se embriagando miudinho" (Rosa, 2001, p. 52); "Dlena, ei-la - jeitinho, sorrisinho, dolo." (Rosa, 2001, p. 53).

$\mathrm{O}$ fato de a personagem desejar postergar o encontro do casal e manter Teresinho preso em uma terra estrangeira coloca Dlena em uma posição semelhante a de Calipso, rainha da ilha de Ogígia, a qual, na Odisseia, mantém Ulisses sob seu domínio durante sete anos e pretende anular a força que Penélope ainda exerce sobre o marido. Segundo o Dicionário de Mitos Literários de Pierre Brunuel:

"Aquele que esconde" vive na ilha de Ogígia, que é, segundo Homero, o "umbigo do mar". Desse local incomparável, privilegiado, à maneira de Circe e de Penélope, a ninfa Calipso fia. Com sua lançadeira de ouro ela também tece junto à lareira, acompanhada por suas servas, um tecido de extremo refinamento. Ao produzir os fios maravilhosos, ela também deseja que esses liames que não deixariam de ser liames sirvam para uni-la a Ulisses, tornando-os esposos, e que esses liames confiram imortalidade a ele. (Brunuel, 2005, p. 380)

Lembra-nos ainda Brunuel que é Calipso quem tece as velas da embarcação de Ulisses, uma vez que Zeus a obrigara a renunciar ao próprio desejo: "Marcel 
Bréal nos apresenta Calipso como aquela que vela, que se envolve e que envolve com brumas." (Brunuel, 2005, p. 380). A ninfa Calipso, portanto, é também uma tecelã, como descrito no canto $\mathrm{V}$ da Odisseia:

"onde vivia/ a ninfa de belas tranças. E encontrou-a lá dentro./ Ardia um grande fogo na lareira, e ao longe, / por toda a ilha, se sentia 0 perfume a lenha de cedro/ e incenso, enquanto ardiam. Ela cantava com linda voz; e com lançadeira dourada trabalhava ao seu tear."(Homero, 2010, p. 92)

Anne Bergren (2008, p. 63), também nota que, para além da figura sedutora, Calipso assume ainda um papel materno, uma vez que em sua companhia Ulisses experimenta a completude, como só é possível no útero. O herói depende de seus cuidados e na ilha de Calipso, espécie de éden, todas as suas demandas são atendidas. Nesse espaço de calor cercado pelas águas, a autora reconhece o ambiente uterino. Desse modo, a saída da ilha de Ogígia corresponderia a um renascimento para Ulisses.

A relação de Dlena e Calipso, portanto, é reafirmada pelo título da narrativa, devido à íntima relação da deusa com a vela- ainda que o significante em Homero remeta ao tecido que orienta o navio e em Rosa seja ressignificado pelo objeto de cera. Outra característica que vincula as personagens é a capacidade de serem aquelas que se escondem: Teresinho só se dá conta de quem é Dlena no momento final da narrativa, quando, por meio da gargalhada, ela desvela sua faceta má - ao longo de todo o conto, ela se esconde em meio à doçura, demosntrando interesse em escutar as aflições do protagonista.

Nota-se ainda que Dlena esconde as cartas de Zidica e por meio desse ardil insiste em ofuscar a memória que Teresinho tem da noiva. Dlena quase consegue enredar Teresinho em sua teia e prendê-lo em sua ilha, rompendo as naus discursivas que o poderiam o levar de volta para Zidica e São Luís:

O narrador reconstitui a trama urdida em torno de Teresinho e torna perceptível que Dlena tem por objetivo prender a atenção do personagem e destruir, aos poucos, a vida pretérita e os planos futuros de Teresinho. Para concretizar esse ardil, Dlena utiliza o poder do discurso, mediante instruções que desviam o rapaz do projeto matrimonial. (Diogo, 2012, pp. $117,118)$

O paralelo Zidica/Penélope e Dlena/Calipso pode ser ainda enfatizado pelo fato de o narrador contrastar a vivacidade e capacidade de sedução de Dlena à passividade insípida de Zidica. No poema homérico, a beleza de Calipso é incomparável, mas mesmo assim Ulisses deseja retornar para sua esposa mortal: 
"apesar do desejo que sentes de ver/ a esposa por que anseias constantemente todos os dias./ Pois eu declaro na verdade não ser inferior a ela,/ de corpo ou estatura: não é possível que mulheres/ compitam em corpo e beleza com deusas imortais." (Homero, 2010, p. 97).

A personagem Dlena, consciente de seus dons de sedução, tal como Calipso, procura acentuar a falta de carisma de Zidica, enfatizando seus erros gramaticais e sua bondade insossa. O conto, portanto, resgata uma série de tropos da tradição literária:

\footnotetext{
a feiticeira, contra quem se voltam seus próprios ardis, o jovem esposo prometido que finalmente volta à ilha, espaço da espera de uma quase inexistente figura feminina, cuja única força parece residir exatamente onde se dá, em aparência, sua fraqueza: falta-lhe força verbal, a palavra que esclarece, invoca e conclama. Dlena o sabe, portanto, procura descaracterizar a ela e a seus possíveis encantos. (Passos, 2000, p. 208)
}

A figuração de Dlena enquanto feiticeira, também pode ser percebida na seguinte passagem: "Foi ela quem abriu o envelope; o iá-iá-iá de rir - riu de modo desusado." (Rosa, 2001, p. 53). Por meio da onomatopeia, Rosa resgata nesse fragmento a risada malévola típica das feiticeiras e bruxas das histórias infantis. A construção da personagem Dlena se dá por um jogo de esconder-se e desvelar-se. $\mathrm{Na}$ maior parte do tempo ela é capaz de dissimular com fraternura sua vilania, contudo em diversos momentos do texto a sua faceta de bruxa-aranha emerge, irrompendo sobretudo em seu olhar e em seu sorriso: "olhos de gata amiga, toda convidativa."(Rosa, 2001, p. 51) "sorriso do amarelo mais belo"(Rosa, 2001, p. 53). Dlena é, portanto: "o sujeito que porta o $\mathrm{D}$ da diferença, do desconhecido, do diabólico - traços dispersos de sua caracterização até o desfecho revelador." (Passos, 2000, p. 205) e que procura encobrir-se em uma aparente docilidade.

Desse modo, as linhas tradicionais de Zidica - que bordam enxovais e trajetórias lineares- opõem-se às linhas transgressoras de Dlena - que tecem teias de sedução e prazeres. Segundo Passos (2000), a jovem-aranha Dlena usa a palavra para lograr e a linguagem, ao rearranjar palavras e expressões, reflete as rearticulações promovidas por Dlena na trajetória de Teresinho. ${ }^{60}$

\footnotetext{
${ }^{60}$ Opostamente a jovem-aranha utiliza a palavra e suas possibilidades para lograr. Sem o dizer, quer o moço repartido ainda mais e em direção precisa: a sua. Daí a relevância da lógica verbal, ancorada em diferentes inversões. Estendendo-se do rearranjo proverbial "da pulga atrás da orelha" à troca de vocábulos ou da ordem estereotipada ("Amava-a com toda fraqueza do seu coração"; "tremefez-se de perdê-la"etc), a linguagem vai
} 
Os fios de Dlena visam a desmanchar a urdidura de Zidica, e essa tentativa de desarticulação também se dá via palavra: enquanto a noiva tenta, por meio da palavra escrita enredar Teresinho e trazê-lo para o casamento, Dlena por meio das palavras ao pé do ouvido procura desestabilizar o amor já prometido:

\begin{abstract}
Assim conforme instruções, ele envia "carta curta, sem parte emotiva" à noiva, que the responde "simplórias simples cartinhas reles ternas". As faltas gramaticais, rápida e gentilmente assinaladas por Dlena, seguem a artimanha de destrinçar os fios amorosos do par, enquanto Zidica, "a doçura insípida da boa água", tece os fios tradicionais do enxoval em São Luís...”tão quieto/.../ tão certo". (Passos, 2000, p. 205)
\end{abstract}

Em contrapartida, o percurso de Dlena difere do de Calipso no momento em que a personagem rosiana não se sujeita aos desígnios do santo e mantém sua empreitada para afastá-lo da noiva, enquanto a ninfa é obrigada a deixar Ulisses partir por ordem de Zeus. Além disso, a personagem de Rosa é desmascarada enquanto a deusa passa de algoz a auxiliar, que guia a nau de Ulisses em segurança até o seu próximo destino, contudo, Dlena não estabelece parentesco apenas com Calipso. Ela também evoca, por eco fonético, Helena, a mais bela das mulheres:

Ativa, viril, esta também não se desvela: Lena, He-lena, Mada-lena, Maria Lena (ou associada ao substantivo latino "lena, ae = alcoviteira) etimologicamente, lembram beleza, culpa e sedução, mas nenhuma das possibilidades determina seu lugar na "linguagem instituída. (Passos, 2000, p. 205)

Assim, Dlena, estabelece seu lugar na linhagem das tecelãs fatais cujo novelo de sedução desestabiliza o destino dos demais, enquanto Zidica resgata a sensatez de uma Penélope que borda o destino com paciência em suas tramas têxteis e textuais:

As mulheres de "A vela ao diabo" representam, assim, duas das inúmeras faces da configuração do feminino em Rosa. Bordado e escrita são traçados que as determinam socialmente, sem deixar de acentuar o papel de cada uma nos vínculos amorosos. Zidica retoma a função tradicional da noiva e esposa, destacada sobretudo nos contos concernentes às donzelas; Dlena, por sua vez, faz coro com as que não se rendem cegas aos padrões da ordem (masculina?) em larga medida assumida pela mulher. (Passos, 2000, p. 208)

Teresinho deixa-se envolver na teia de Dlena, apassivando-se diante da amiga e esquecendo pouco a pouco a amada que o espera em São Luís. Teresinho 
configura-se como "um sujeito frágil e indeciso. Atormentado pela possibilidade de desilusão amorosa, procura resolver a questão pela via do pensamento mágico velas e rezas - e não por meio de atitudes práticas e ativas." (Diogo, 2012, p. 45). Nesse sentido há um parentesco entre Teresinho e Jó Joaquim, uma vez que ambos os protagonistas não assumem plenamente o lugar do patriarca que se responsabiliza pelo seu destino e pelo destino daqueles que o cercam por meio da força e da atividade.

A fragilidade de Teresinho é ainda enfatizada em sua onomástica, uma vez que as formas femininas Teresa ou Teresinha são muito mais comuns: "Teresinho atesta em seu nome uma ambiguidade entre o masculino e o feminino, apresentando-se como um homem cujo nome - Teresinho - sendo pouco usual e feminino, evoca fragilidade" (Diogo, 2012, p. 116)

No desfecho da narrativa, Teresinho percebe que Dlena o havia envolvido em um ardil. Por meio de sua risada maléfica e do olhar "rancordioso" ela se revela mais próxima ao "diabo" e ali a vela da paixão apaga-se: "Ali algo se apagara"(Rosa, 2001, p .53). O uso do pronome indefinido "algo", entretanto, dá margem à múltipla interpretação, e, seguindo o fio da escrita que permeia o texto, faz-se possível afirmar que é nesse momento que também se apaga a rasura que Dlena tentara inscrever na estória de Teresinho e Zidica.

O protagonista volta, então, para a amada, casa-se e vivem "infelizes e felizes misturadamente". (Rosa, 2001, p. 53). Rosa encerra a sua narrativa de maneira magistral: "rompendo o feérico e sacralizado "felizes para sempre" para presentear os noivos com o morno cotidiano de viverem "felizes e infelizes misturadamente" "(Passos, 2000, p. 209).

Em "A vela ao diabo", o narrador explora a incerteza de Teresinho diante da aparente indiferença da noiva, Zidica, que mora em São Luís. Devido à ausência das cartas, Teresinho procura ajuda na igreja, repetidas vezes, tanto quanto se repete sua desconfiança e sua dúvida em relação à permanência do amor no coração de sua noiva ausente. Essa repetição da dúvida e do movimento de ler-escrever cartas evoca o traço da poética do mito

Ele então se propõe a fazer uma novena, almejando o resgate do amor prometido, mas passa também a pensar em Dlena. O conflito, portanto, desdobrase: antes concentrado na incerteza com relação à intenção da noiva, agora se converte na incerteza dos próprios sentimentos que nutre por uma e por outra. 
Assim, a metáfora "As mulheres, sóis de enganos" (Rosa, 2001, p. 50), ganha amplitude. As mulheres são sóis que, como tais, iluminam intensamente, mas que ao mesmo tempo transmitem forte luz de enganos. No conto, esses enganos podem se referir tanto ao que elas sentem (como, por exemplo, o arrefecimento aparente do sentimento de Zidica) quanto ao que elas podem provocar no homem, como a dúvida estabelecida no enredo, levando Teresinho a se dividir (e, portanto, ficar em uma situação de engano) em relação a uma ou outra mulher. Ao optar pela noiva, acaba o conflito da dúvida, mas se instaura o da felicidade, já que "foram infelizes e felizes, misturadamente".

O movimento pendular da felicidade recorre à repetição que lembra ora a realidade (pressupõe-se que a vida real é isso, uma mistura de dores e prazeres, indefinidamente) ora a um conto de fadas, trocando o narrador a locução adverbial temporal "para sempre" pelo advérbio de modo "misturadamente". Embora assimétricas, essas expressões recorrem a uma estrutura clássica, subvertida pela dúvida. Vale lembrar que o nome do personagem pode aludir à cantiga infantil popular que aborda a escolha de uma personagem (Teresinha de Jesus, que se vê acudida por três cavalheiros, e tem de escolher um deles para dar sua mão), invertendo-a.

Excetuando-se a novena, o tempo da narrativa não é marcado explicitamente e, por isso há poucos dados concretos para ancorá-lo em um momento histórico. Logo, essa indeterminação histórico-social remete ao mítico-fabular, constante na obra rosiana.

O conto apresenta aspectos que aludem à oralidade, como o faz a própria referência da cantiga infantil já citada. Além disso, o narrador adota expressões que advêm de falas populares consagradas pelo uso, subvertendo, por exemplo, em "Amava-a com toda a fraqueza de seu coração", a recorrente expressão "com toda a força de seu coração". Também subvertida, a expressão "estar com a pulga atrás da orelha" é empregada em "Teresinho inquietou-se, trás orelha saltando-lhe pulga irritante." (p. 50). Como já assinalado, as rearticulações presentes na linguagem refletem a mobilidade das situações do enredo e os rearranjos promovidos por Dlena, bem como reforçam o elo do conto rosiano com a narrativa mítica. A oralidade, conforme já explicitado na análise de "Desenredo" e recorrentemente aludido pela crítica, é uma marca importante da obra de Guimarães Rosa e apresenta vínculos estreitos com a poética do mito. 
Ainda no terreno de tal poética, ressalta-se a presença da metáfora, aspecto fulcral da obra de Guimarães Rosa, tal como se vê em "As mulheres, sóis de enganos." (p. 50) e em "(...) num dolorir-se, voluntário da insônia" (p. 50). A formulação assertiva, igualmente um componente da estrutura mítica, aparece com força em Rosa, na tentativa de recuperar dados da sabedoria popular e no emprego de aforismos. Alguns segmentos como "As mulheres, sóis de enganos." (p. 50) e “Tudo, quanto há, é saudade, alternando-se com novidades." (p. 53) mostram essa formulação de uma "verdade" que não se propõe a ser questionada e que guarda um ensinamento para o leitor.

Arcaico e moderno aparecem no conto numa junção equilibrada: o aspecto da união amorosa, como sendo uma instituição que se materializa no casamento oficializado e se ratifica pela igreja, divide espaço com o fato de Teresinho cogitar, embora não consuma, sua ligação com Dlena. Ainda nesse terreno, a formulação feérica "e foram felizes para sempre" sofre uma ruptura quando se instaura a palavra "infelizes" e quando se emprega o advérbio "misturadamente".

\subsection{Ponto Corrente}

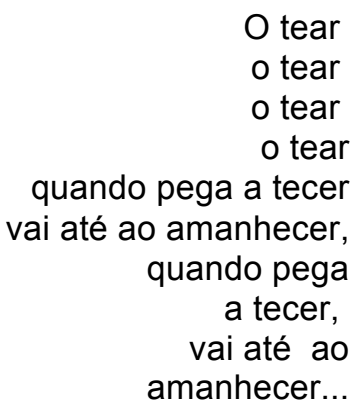

(Batuque dos Gerais) (Rosa, 2001, p. 153)

A leitura comparativa dos textos desse capítulo com os referenciais míticos das tecelãs abre um leque de significação que se perde na análise isolada. No caso específico de Tutameia, essa metodologia parece-nos ainda mais contundente, uma vez que: "Ler Tutameia é des-ler o dito e ler o não-dito". (Izolan, 2009, p. 8), de modo que a comparação pode iluminar os aspectos do não-dito que poderiam permanecer na penumbra em uma leitura tradicional. Wolfgan Iser, ao afirmar que "no processo de leitura interagem incessantemente expectativas modificadas e 
lembranças novamente transformadas" (Iser, 1999, apud Gama, 2002, p. 309) contribui para a nossa hipótese da validade da reelaboração do material mítico nos contos modernos e contemporâneos.

Além disso, o "contar desmanchando" (Passos, 2001) de "Desenredo" ilustra essa proposta de leitura, pois rompe a expectativa do leitor, formatada pela tradição literária e lembranças advindas de leituras anteriores, propondo finais surpreendentes: em "Desenredo" não só o perdão do adultério, mas, sobretudo, o seu anulamento; em "A vela ao diabo" a subversão do felizes para sempre em "felizes e infelizes misturadamente."

Os contos investigados nesse capítulo apresentam pontos de contato bastante contundentes e, portanto, vale realizar uma aproximação das narrativas. Dlena e Livíria pertencem à mesma linhagem de tecelãs fatais, cuja vilania é mascarada em aparente doçura. Em Livíria temos a pureza do lírio mesclada à vilania, em Dlena o olhar "rancordioso" e o riso desusado de feiticeira-aranha são mascarados por aparente "fraternura".

Já as personagens masculinas aproximam-se pela passividade que as submetem aos ardis dessas mulheres sedutoras. Tanto Jó, quanto Teresinho, deixam-se envolver e encantar pela beleza e pela palavra tecida por suas amadas, sem perceber que eram encaminhados para a "perdição". Os homens também são incapazes de perceber os índices que são salpicados na narrativa e acabam surpreendidos pelas mulheres.

Entre "Desenredo" e "A vela ao Diabo" as relações são prementes pois podemos observar a reiteração de algumas imagens nas duas narrativas. Para além da força motriz da palavra e do mecanismo do "contar desmanchando" (Passos, 2001) como procedimento estético, as duas narrativas retomam a centralidade do olhar, a imagem da mosca e a recorrência do número três.

Em "Desenredo", os olhos de Livíria são centrais no jogo da sedução, contudo em "A vela ao diabo", os olhos de gata de Dlena "olhos que nem seriam mesmo verdes, caso houvesse nome para outra igual cor."(Rosa, 2001, p. 52) que se tornam abruptamente "olhos sem cinza - rancordiosa." (Rosa, 2001, p. 53) também são condutores das transformações no conto.

A mosca em "Desenredo" aparece não só nos "olhos de viva mosca" de Livíria senão ainda no nome Lívia do qual Livíria é desdobramento: "O termo matriz, Lívia, de acordo com Silveira Bueno (1966) significa "pequenas moscas com cabeça 
quadrada e côncava" ou "nome próprio de mulher impertinente". "(Montagna, 2011, p. 03). Já, em "A vela ao diabo", o inseto comparece nos "olhos de gata, toda convidatividade, a moça esvoaçadora." (Rosa, 2001, p. 51), o convite no olhar assemelha-se à vivacidade dos olhos de Livíria e a expressão moça esvoaçadora alude foneticamente à mosca esvoaçadora como percebido por Passos (2000, p. 203).

O número três, além de estruturar os triângulos amorosos nas duas narrativas (Livíria- Jó Joaquim - Marido/ Teresinho - Dlena - Zidica), é reiterado em "Desenredo" em "passa três vezes perto da gente a felicidade"; "não a imaginara jamais ter o pé em três estribos". Já em "A vela ao diabo", o arcanjo Miguel "revoa três vezes na Bíblia"(Rosa, 2001, p. 51) e Teresinho passa a se encontrar com Dlena após três dias da novena: Não nos passa despercebido o número 3 , o início do triângulo ao terceiro dia, o tridente do diabo: modos de compor roseanos. (Rodrigues e Santos, 2013, p. 357).

Assim, Dlena e Livíria invocam a dimensão da palavra poética que encanta, subverte e rasura os enredos tradicionais. Como filhas de Pandora e Helena são capazes de persuadir e encantar suas presas imobilizadas em suas teias de sedução e engano. Mulheres-Phármakon; cuja ambivalência e impossibilidade de apreensão unilateral constituem seu poder de arrebatamento 


\title{
Destecendo Penélope: Entre fabulação e resistência
}

\author{
"Agora eu sei porque Penélope tecia durante o dia \\ e desmanchava o trabalho à noite \\ enquanto Ulisses viajava pelo mundo. \\ Dizem que era para manter seus pretendentes à distância; \\ mas eu sei que era o próprio- o nosso próprio- \\ - $\quad$ interminável processo que a ocupava" (Koltuv, 1990, p. 113)
}

Já vimos no primeiro capítulo desse trabalho que a figura da tecelã foi vinculada durante toda a Antiguidade ao confinamento feminino no âmbito do óikos, e, paradoxalmente, constituía a principal atividade criativa feminina, seu criar signos. A tecelagem foi ao longo da história feminina metonimizando o poder de resistência feminina, por meio de uma inversão semântica de sua função social. Posteriormente, tornou-se a metáfora por excelência do discurso feminino. Se aparentemente a tessitura era a prisão feminina, na verdade, foi por meio de agulhas que as mulheres efetivamente teceram a sua voz.

Desde a Odisseia e da comédia Lisístrata, diversos textos da Grécia Arcaica e Clássica figuram o tecer como resistência: as mulheres da comédia, por exemplo, para além da greve de sexo, marcam uma transgressão graças ao ato de tecer e destecer, já que de seus fusos dependia todo o produto têxtil da cidade. ${ }^{61}$

Essa substituição de valores relacionados ao tear, que podem ser observados em diversos momentos da literatura ocidental, têm marcado de maneira expressiva a literatura contemporânea de autoria feminina. Encontramos, nessas obras, neotecelãs que subvertem a opressão patriarcal e produzem discursos transgressores em seus teares enquanto produzem nas mesmas malhas produtos criativos de delicadeza.

Essa ambivalência entre fabulação e resistência irá sustentar a análise de dois contos brasileiros contemporâneos em que a figura da tecelã reaparece com contundência: "Colheita" (1997), de Nélida Piñon e "A Moça Tecelã" (2013), de Marina Colasanti. 
3.1 Colheita: A tessitura prosaica da voz

Mitos e tradições relacionam

os trabalhos de lavrar a terra

com aqueles do fio,

os mais antigos em nossas memórias.

Esses trabalhos do fio

nos sulcos são atos de criação

que por muito tempo fizeram da lã

uma representação da terra

e dos campos cultivados.

(Brunuel, 2005, p. 383)

Em "Colheita", publicado em 1973 em Sala de Armas, narra-se a história de um casal profundamente apaixonado que vive próximo à natureza. Apesar de serem muito felizes juntos, o homem decide viajar por sede de completar-se e de acumular vivências exóticas. Apesar de sua tristeza, a mulher aceita que o homem parta. Muitos anos se passam sem que ela tenha notícia do companheiro, mas, ela fiel, aguarda seu retorno. Nessa espera, ela se aprofunda e redescobre as potencialidades do feminino que se escondem nos cuidados domésticos. Quando o marido finalmente retorna, deseja narrar suas aventuras pelo mundo. A mulher, no entanto, priva-o da palavra e narra com volúpia tudo o que havia vivido sem precisar deixar seu lar. Nesse confronto, o marido percebe que a viagem dela fora muito mais profunda do que a que ele empreendera e volta-se para o aprendizado das tarefas domésticas ao lado da esposa.

Ainda que não tenha sido extensivamente explorada pela crítica, a atenção dada a essa narrativa tem aumentado nos últimos anos ${ }^{62}$. A maioria das abordagens lê "Colheita" pela via dos estudos de gênero, alguns trabalhos reconhecem sua feição mítica e há ainda um artigo da área de semiótica que o analisa. Iremos

\footnotetext{
${ }^{62}$ Alguns artigos que interpretam "Colheita": "Tessituras míticas em "Colheita" de Nélida Piñon" (2010), de Sueli Maria de Oliveira Regino; "Caminhos de transformação e ruptura em Colheita, de Nélida Piñon" (2012), de Alleid Ribeiro Machado; "A representação da mulher no conto Colheita, de Nélida Piñon: mulher emancipada."(2007), de Sarah Casagrande e Lúcia Osana Zolin; "A representação da mulher na narrativa de Nélida Piñon" (2008) e "A construção do feminino nas literaturas portuguesa e brasileira contemporâneas: Miguel Torga e Nélida Piñon" (1999), de Lúcia Osana Zolin; "Imagens em ruínas, identidades reinventadas: uma leitura de "Colheita", de Nélida Piñon", de Terezinha Taborda Moreira; "Categorias narrativas e figura feminina no conto "Colheita", de Nélida Piñon" (2011), de Liliane Delorenzi e Paula Aquino; "Diálogo intertextual entre os contos "Colheita" e "Penélope" (2012), de Neila da Silva de Souza e Elton Emanuel Brito Cavalcante; "O mito de Penélope e sua retomada na literatura brasileira: Clarice Lispector e Nélida Piñon” (2012).
} 
comentar alguns desses trabalhos, sem a pretensão de esgotar as discussões ali presentes.

O estudo mais aprofundado acerca de "Colheita", contudo, foi realizado no Mestrado de Denise Dumith, "O mito de Penélope e sua retomada na literatura brasileira: Clarice Lispector e Nélida Piñon" (2012) já mencionada anteriormente. Dumith empreende uma interpretação aprofundada em paralelo com o mitema de Penélope, articulado em três dimensões: o mitema da espera, o mitema da fidelidade e o mitema do engano. Alguns aspectos elucidados pela autora serão recobrados ao longo de nossa análise.

O equilíbrio inicial do conto é quebrado pela separação do casal devido ao desejo do marido de conhecer o mundo: "Um amor que se fazia profundo a ponto de se dedicarem a escavações, refazerem cidades submersas em lava (...) Até que ele decidiu partir. Competiam-Ihe andanças, traçar as linhas finais de um mapa cuja composição havia se iniciado e ele sabia hesitante" (Piñon, 1997, p. 97).

Como assinalado pela crítica, o casal não é nomeado, o que os ancora em um tempo mítico fundamental na construção do enredo: "como ocorre nos contos maravilhosos, essa generalização irá afastar as personagens da realidade objetiva, situando-as em um tempo e um espaço mítico." (Regino, 2010, p. 02)

As personagens do conto estabelecem uma relação analógica com Penélope e Ulisses, os protagonistas de Odisseia, ainda que sejam denominados "homem" e "mulher". Vários traços permitem o reconhecimento de tal vínculo: a partida do homem paralela à espera da mulher, a presença de pretendentes, a referência textual à guerra e, como percebido por Denise Dumith a ênfase na homofrosiné (em grego afinidade intelectual) do casal: "A primeira qualidade a ser percebida por ele na moça é a altivez, característica dos portadores da métis, identidade comum do casal Odisseu/Penélope." (Dumith, 2012, p. 229)

Tal generalização, ao mesmo tempo os apequena, já que não estamos tratando dos grandes heróis da epopeia, e os torna figuras universais: "deixar de atribuir o antropônimo é uma das formas de respeitar o interdito, já que nomear indica um procedimento para expor a identidade (...) indica o deslocamento dos paradigmáticos feitos heróicos da aristocracia clássica para o anonimato a englobar pessoas comuns." (Dumith, 2012, p. 229)

$\mathrm{Na}$ narrativa predomina tal atmosfera de indeterminação também fruto do tempo mítico. Ao lado da ausência de nome das personagens paira a indefinição 
social de ambos, já que há a ausência de traços históricos, locais concretos, modas, usos e representações de uma classe que definam social e temporalmente o enredo. Embora haja a marca patriarcal da aldeia, não é possível definir exatamente a época em que se passa o conto (ainda que a menção ao helicóptero delimite um traço de modernidade), nem tampouco colocar a questão da classe social das personagens. Plana sobre a obra a ausência de contornos, que espelham na fatura a ausência que propulsiona o enredo.

O homem parte em paralelo a Ulisses, porém seu destino não é a guerra homérica, e sim sua função social: "Competiam-Ihe andanças, traçar as linhas finais de um mapa cuja composição havia se iniciado e ele sabia hesitante." (Piñon, 1997, p.97). A partida é caracterizada, nesse caso, mais como uma convenção social, embora exista no homem a ânsia da caracterização masculina de descobrir, desvendar o mundo, elemento próprio da visão do herói que sai em busca de vitória. A partida é socialmente imposta, mas racionalmente aceita, afinal se ele era "Um rosto proibido desde que crescera." (Piñon, 1997, p. 97) não precisava se submeter ao estereótipo masculino estabelecido.

O homem de "Colheita" opta pela partida, enquanto na epopeia o herói Ulisses é obrigado a partir para a Guerra de Tróia. Na Odisseia, partir é uma questão de obrigação social, de dever com a comunidade. Ulisses tenta protelar sua partida até o último instante, usando sua astúcia para se fingir de louco. Esse episódio não está no corpo da Odisseia, mas pertence a seu imaginário, como já elucidado na análise de "Desenredo" (2001). Apesar das diferenças entre os protagonistas, sua relação com uma mulher-terra é análoga:

uma constatação aproxima os dois heróis. As outras mulheres para Odisseu são ilhas, diferentes, mas sempre ilhas, em uma das quais permanece sete anos com Calipso e, em outra, um ano com Circe. Só Penélope é terra firme, o continente de seu afeto. De igual modo, para o homem de "Colheita", a mulher é "a certeza de se avizinhar do paraíso" (PIÑON, 1997a, p.100). " (Dumith, 2012, p. 243)

Nessa narrativa, é a ânsia do homem por partir que abala o equilíbrio inicial, em que homem e mulher viviam em harmonia com a natureza. O título do conto, a princípio, parece vir da atividade do homem, que vivia do que plantava nas sendas da montanha. Com a atividade de plantar, ele tornava suas vidas simples, porém férteis. A colheita, em uma primeira análise parece partir dele, da atividade que desempenha como agricultor: "Dominava as paisagens no modo ativo de agrupar 
frutos e os comia nas sendas minúsculas das montanhas, e ainda pela alegria com que distribuía sementes. A cada terra a sua verdade de semente, ele se dizia sorrindo." (Piñon, 1997, p. 97).

Os protagonistas viviam um amor intenso, que aparentemente bastava para fazer suas "vidas completas": "Um amor que se fazia profundo a ponto de se dedicarem a escavações, refazerem cidades submersas em lava." (Piñon, 1997, p. 97). Afirma-se esse amor já no primeiro parágrafo. Embora tanto na Odisseia quanto em "Colheita" o enredo se inicie pelo homem (inclusive no texto grego "homem" é a primeira palavra da epopeia. ${ }^{63}$ ), em "Colheita" a mulher é logo introduzida, bem como o amor - sustentação para ambos. Ele e ela encontravam na simplicidade do cotidiano um universo rico.

Além disso, estabelecera-se um relacionamento com o qual a sociedade local (a aldeia) não compactuava, embora a condenação social não impeça o casal de viver seu romance, à semelhança de "Desenredo" (2001), de Guimarães Rosa. Os protagonistas rejeitam os valores da "queda" sob os quais são julgados pela aldeia, representante da sociedade patriarcal e conservadora, de modo que vivem, no primeiro momento, numa espécie de Éden, imagem sugerida pela abundância vegetal e pela completude impressa em um sobre o outro:

A aldeia rejeitava o proceder de quem habita terras raras. Pareciam os dois soldados de uma fronteira estrangeira, para se transitar por eles, além do cheiro da carne amorosa, exigiam eles passaporte, depoimentos ideológicos. Eles se preocupavam apenas com o fundo da terra, que é o nosso interior, ela também completou seu pensamento. (Piñon, 1997, p. 97)

O homem, apesar da companheira, passa a se sentir atraído pelo sol, no entanto, sustentava-se pelas raízes: "Inspirava-Ihes o sentimento a conspiração das raízes que a própria árvore, atraída pelo sol e exposta à terra, não podia alcançar, embora se soubesse nelas." (Piñon, 1997, p. 97). Isto é, ele passa a apresentar um comportamento tipicamente masculino, contudo o que o ancora são elementos femininos, com os quais a presença da mulher o nutre: nesse contexto, já é possível perceber que ela é mais independente, enquanto ele precisa dela.

Entretanto, o homem, pressionado pelos valores patriarcais que os cercavam, cede e parte, deixando sua mulher à espera. Nesse ponto, podemos começar a interpretar o título "Colheita" sob outra gama de significação, pois diante da partida 
será estabelecido um hiato temporal. Podemos pensar a colheita como resultado de um processo que implica necessariamente plantio e crescimento. Logo , é possível avaliar esse tempo do crescimento, imbricado na colheita, como o tempo da espera, que será a postura da mulher. O hiato temporal revela-se inerente ao ciclo da natureza:

\footnotetext{
Com efeito, o ciclo vegetal, que fecha da mente à semente ou da flor à flor, pode ser, tal como o ciclo lunar, segmentado em rigorosas fases temporais. Há mesmo sempre no enterramento da semente um tempo morto, uma latência que corresponde semanticamente ao tempo morto das lunações, à "lua negra". (DURAND, 2002, p.296)
}

A espera, a gravidez da semente, seria um elemento feminino, a ser retomado com o desdobramento da análise. Voltando ao fio do enredo, Ela, mulher sem nome, não protesta contra a partida do homem - o silêncio evidencia a sua ausência de discurso. Ela reage apenas com lágrimas; não assume voz, não interfere no destino com palavras. A mulher sofre, pois acredita na ilusão da completude, pensando que o amor de ambos bastava e que ele nada encontraria fora dali, porém aceita que o homem vá, concedendo-lhe a liberdade que a sua espécie exigia.

A estruturação da linguagem do conto se faz, repetidas vezes, pela subordinação adverbial, particularmente em algumas passagens, reforça-se a ideia de concessão: "Quando se fez homem encontrou a mulher, ela sorriu, era altiva como ele, embora seu silêncio fosse de ouro, olhava-o mais que explicava a história do universo." (Piñon, 1997, p. 97); "Inspirava-lhes o sentimento a conspiração das raízes que a própria árvore, atraída pelo sol e exposta à terra, não podia alcançar, embora se soubesse nelas." (Piñon, 1997,p. 97); "Sempre os de sua raça adotaram comportamento de potro. Ainda que ele em especial dependesse dela para reparar certas omissões fatais." (Piñon, 1997, p. 98); "A delicadeza comoveu a mulher, embora os diálogos do homem a inquietassem."(Piñon, 1997, p. 98).

O emprego desse tipo de subordinação circunscreve-se, afinal, ao papel da mulher que, em certa medida, concede ao marido a anuência para que parta, sem recriminações, sem cobranças, porém com reiterada presença de dor, de solidão, de persistência diante da ausência do homem: resigna-se a sua decisão, embora notadamente vá sofrer.

Além disso, nessa passagem a mulher apresenta-se tão carente de voz quanto Penélope na Odisseia. Em poucos momentos, a personagem grega assume seu discurso, sabemos o que ocorre mais pela fala de outras personagens 
(Menelau, Agamenon, a mãe de Ulisses, os pretendentes no Hades) do que por ela própria. Em seu caso nem o narrador tem acesso ao interior da personagem. Um exemplo de seu silenciamento pode ser encontrado no canto I, em que seu filho Telêmaco Ihe diz: "Agora volta para os teus aposentos /e presta atenção aos teus lavores,/ ao tear e à roca; e ordena às tuas servas que façam os seus trabalhos. / Pois falar é aos homens que compete, a mim sobretudo: sou eu quem manda nesta casa" (Homero, 2010, p. 35)

A ausência de discurso feminino é, deste modo, enfocada pelos dois textos, ainda que pareça mais natural tal falta no período grego arcaico do que no século XX. É ainda importante ressaltar que Penélope já aí é associada "ao tear e à roca", como tecelã por excelência.

No conto, em tal desequilíbrio inicial, também se percebe um descompasso nos papéis da mulher e do homem. Se, antes, essas polaridades estavam em equilíbrio, agora, o homem silencia a mulher e parece maior do que ela no desenho textual. Virgínia Woolf em seu ensaio "Um Teto Todo seu" (2004), cria uma imagem bastante forte para esse homem que parece sobrepor-se à mulher: "Em todos esses séculos, as mulheres têm servido de espelhos dotados do mágico e delicioso poder de refletir a figura do homem com o dobro de seu tamanho natural" (Woolf, 2004, p. 42). Em "Colheita", o homem parece ter no espelho (que será reduplicado em retrato) o dobro de tamanho da mulher - imagem que sugere superioridade e poder masculinos.

O homem segue o plano, o modo linear com que supostamente deveria conduzir sua vida. Não há ruptura por parte da figura masculina, o homem precisa viajar, pois: "Sempre os de sua raça adotaram comportamento de potro. Ainda que ele em especial dependesse dela para reparar certas omissões fatais." (Piñon, 1997, p.98)

Além disso, ele assume comportamento de potro, não de cavalo. É de certo modo por imaturidade que ele parte, com o intento de provar para si mesmo que consegue sustentar-se sem a mulher, sem a qual não consegue lidar com as faltas de seu ser. O corcel é ainda uma referência, em Odisseia, à nau. Penélope afirma sobre a viagem de Têlemaco na Telemaquia: "Que necessidade tinha ele de embarcar em naus velozes, que são corcéis do mar." (Homero, 2010, p. 86), enfatizando a correspondência entre cavalo e partida. 
Em seguida, o homem admite estar feliz no espaço ao qual pertence, mas expulsa a si mesmo do Éden, por se submeter aos valores patriarcais: "Sua última frase foi simples: com você conheci o paraíso." (Piñon, 1997, p. 98). Ele parte sem realizar um juramento de retorno, assim como Ulisses, o retorno (nóstos) é uma premissa que garante a glória (kléos) do herói ${ }^{64}$. O emprego do pretérito perfeito no excerto em destaque confere à frase o sentido de ação concluída, não há no discurso nada que sugira continuidade após essa cisão. Em "Colheita", o compromisso da espera não é explícito, é subjetivo e o juramento é da mulher para consigo mesma, trata-se de um juramento velado de ascetismo: "A partir desta data trancou-se (a mulher) dentro de casa. Como os caramujos que se ressentem com o excesso da claridade." (Piñon, 1997, p.98).

O tempo vai passando e ela, tal como uma Penélope contemporânea, tece ponto a ponto, dia-a-dia, nas malhas do lar e do prosaico, a espera. Entre uma tarefa e outra não deixa que falte uma vela acesa diante do retrato do marido cujo, retorno aguarda com ansiedade.

Não se trata, contudo, de uma espera inerte e passiva, sugestiva de entrega ou fraqueza, é uma espera consciente, livre e criativa: na esfera doméstica, ela recria a si mesma e ao lar que aspira dividir com o amado: "Isso a torna mais receptiva aos objetos triviais, concretos, que a fazem desejar sair do confinamento autoimposto, em lugar de manter-se fiel a uma memória já em principio de esfumação. Portanto, trata-se de uma Penélope com maiores conflitos internos, em lugar dos externos, mais relevantes na Odisseia."(Dumith, 2012, p. 233)

Análoga à Penélope, a mulher escolhe aguardar fielmente o marido. A rainha de Ítaca, segundo as leis locais, poderia ter se casado novamente, já que a morte de Ulisses parecia evidente. A mulher poderia igualmente ter se envolvido com alguém, uma vez que não existia uma promessa formal que a ligasse ao homem. Com o correr do tempo, em ambas as histórias, a independência feminina passa a incomodar a aldeia. Na Odisseia, conforme se assinalou, para driblar um potencial casamento com um dos pretendentes que invadiram a casa de Ulisses, que Penélope recorre ao ardil do tear. Já em "Colheita", os pretendentes aparecem por meio do envio de presentes, revelando que a aldeia a considera livre para assumir

\footnotetext{
${ }^{64}$ Cf. Duarte, Adriane da Silva. A relação entre retorno e glória na Odisseia. Letras Clássicas, no05, p. 89-97, 2001.
} 
um novo compromisso e, de alguma maneira, também dilapidam o patrimônio do homem, ao tentarem demolir a sua memória:

Esforçavam-se em demolir o rosto livre e sempre que passavam pela casa da mulher faziam de conta que jamais ela pertencera a ele. Enviavam-lhe presentes, pedaços de toicinho, cestas de pera, e poesias esparsas. Para que ela interpretasse através daqueles recursos o quanto a consideravam disponível, sem marca de boi e as iniciais do homem em sua pele. A mulher raramente admitia uma presença em sua casa. Os presentes entravam pela janela da frente, sempre aberta para que o sol testemunhasse a sua própria vida, mas abandonavam a casa pela porta dos fundos, todos aparentemente intocáveis. A aldeia ia lá inspecionar os objetos que de algum modo a presenciaram e eles não, pois dificilmente aceitavam a rigidez dos costumes. Às vezes ela se socorria de um parente, para as compras indispensáveis. Deixavam eles então os pedidos aos seus pés, e na rápida passagem pelo interior da casa procuravam a tudo investigar. De certo modo ela consentia para que vissem o homem ainda imperar nas coisas sagradas daquela casa. (Piñon, 1997, p. 98)

A presença da repetição, que resgata a construção mítica no conto, ocorre pelo uso reiterado de verbos no pretérito imperfeito, pelo emprego dos advérbios sempre, às vezes, ainda e dos nomes costumes, sagradas. Essa constância revela que a personagem feminina estabelece, no ritmo das atividades domésticas, um ritual, cuja repetição cíclica remete à estrutura mítica.

A mulher protege o seio do seu lar, mantendo a presença do marido viva, impondo-se sobre aqueles que a cortejam: "A mulher raramente admitia uma presença em sua casa. Os presentes entravam pela janela da frente". (Piñon, 1997, p. 98). Ela mantém a autonomia do lar, protegendo a imagem do homem e o ambiente doméstico. Assim como Penélope, não aceita a corte dos seus pretendentes, deixando que os presentes entrem e saiam da casa intactos, para enfatizar sua escolha de absoluta fidelidade: "De certo modo ela consentia para que vissem o homem ainda imperar nas coisas sagradas daquela casa". (Piñon, 1997, p. 99)

A casa funciona ao mesmo tempo como uma fortaleza, que a preserva contra as investidas dos pretendentes, e como o seu universo particular, no qual ela redescobre os prazeres do prosaico e do ciclo:

A casa e a personagem tornam-se cúmplices na descoberta de uma nova vida, independente do mundo do lado de fora. As grandes transformações acontecem na casa. É o espaço onde vivia o casal, onde ela recebe presentes, onde ela se enclausura e onde acontecem as transformações tanto dela quanto dele. Essa relação acaba por personificar a casa e dar à ela um papel essencial na narrativa (Aquino e Delorenzi, 2011, p. 10) 
Em um certo sentido, a casa e a protagonista parecem coincidir, ambas esperam o retorno do homem e partilham a tessitura da espera e do cotidiano. Ao voltar-se para o interior da casa e evitar a esfera pública, a mulher volta-se para a sua interioridade e para o autoconhecimento.

A mulher segue ritualizando tributos para o seu amado ausente: "Jamais faltou uma flor diariamente renovada próxima ao retrato do homem. Seu semblante de águia." (Piñon, 1997, p. 99). Aqui, reitera-se a noção cíclica, que evoca o eterno retorno do mito, presente na narrativa por meio da rotina e dos afazeres domésticos, a circularidade dos cuidados atribui-Ihes a função ritualística. Ainda na expressão semblante de águia é possível reforçar a associação do homem ao herói Ulisses. No canto XIX da Odisseia, Penélope narra ao herói, que está disfarçado de mendigo, um sonho que tivera e que antecipa o massacre dos pretendentes:

Cá em casa tenho vinte gansos que saem da água Para comer trigo: com eles me alegro quando os vejo Mas da montanha veio uma grande águia de bico recurvo, que se atirou aos pescoços dos gansos, matando-os a todos. Eles jaziam aos montes no palácio, mas a águia voltou Para o éter divino. Eu chorava, embora estivesse a sonhar. À minha volta se reuniam as mulheres de belos cabelos de Aqueus, enquanto eu chorava convulsivamente, porque uma águia matara os meus gansos. Mas a águia regressou; e pousada no alto de uma viga fez parar o meu choro com voz de homem mortal:

"Anima-te, ó filha de Icário, cuja fama chega longe! Isto não é um sonho, mas uma visão verdadeira, que se cumprirá. Os gansos são os pretendentes, e eu, que antes fui águia, agora regresso como marido, que fará que se abata sobre os pretendentes um terrível destino." (Homero, 2010, pp. 322 - 323, grifos nossos)

A águia, além de evocar o herói homérico, parece marcar ainda uma relativa superioridade do homem sobre a mulher, já que se configura como uma ave das alturas. No entanto, ela no papel de Penélope, "pato ou ganso selvagem", ligada à terra irá redescobrir-se no contato com o chão.

Ao adquirir consciência de suas potencialidades criativas e ao aprofundar sua feminilidade a mulher passa a não precisar mais do retrato do marido como guardião de sua fidelidade: "Durante a noite, confiando nas sombras, retirou o retrato e o jogou rudemente sobre o armário. Pôde descansar após a atitude assumida. Acreditou de este modo poder provar aos inimigos que ele habitava seu corpo independente da homenagem." (Piñon, 1997, p. 99). 
A escolha por suprimir a imagem do marido, aparentemente, poderia ser lida como uma quebra na promessa de fidelidade e traduzir uma desvinculação com a figura do amado. Contudo, a ação, acaba reafirmando o vínculo da mulher com o homem. Dumith (2012, p. 235), já assinalara que a decisão de romper com o retrato do marido não marca uma revolta. A autora defende que o gesto tem duas razões mais profundas: o descanso da vigília que a mulher realizara diante da ausência e o enfrentamento da sociedade, provando que mesmo sem a imagem o homem ainda era senhor de seu corpo e pensamento.

Sua atitude, nessa passagem, reforça a opção pela interioridade, pelo conhecimento de si: seu amor está tão enraizado que ela não precisa cultivar uma imagem para prová-lo. Sua fidelidade extrapola os estereótipos e imagens. Em suma, o homem está ali, presente na espera, da qual ela e a casa são templo. A força da mulher cresce diante de tal ruptura, sem que o amor diminua. Ela compreende, enfim, que amor e submissão são conceitos desvinculados.

Nesse ponto do enredo, o desenho do conto muda. Se, no primeiro momento, tínhamos o homem impondo-se sobre a mulher, diminuída e submissa diante do retrato, que condensa a adoração prestada à figura masculina, ao libertar-se dele a mulher dobra de tamanho no espelho. O desequilíbrio entre as polaridades masculina e feminina mantém-se, contudo agora é a mulher que se impõe sobre o homem: "Mas, com o tempo, além de mudar a cor do vestido, antes triste agora sempre vermelho, e alterar o penteado, pois decidira manter os cabelos curtos, aparados rentes à cabeça - decidiu por eliminar o retrato" (Piñon, 1997, p. 99). A opção pelo vermelho é simbólica, pois, ao lado do corte ousado do cabelo traduz uma ruptura com a discrição. A mudança de postura marca a independência da mulher que passa a ser dona do próprio corpo. Ela inverte as trevas da partida do homem amado em uma possibilidade de vida, e se identifica com a vitalidade que emana de seu lar, das tarefas diárias, da culinária.

Após a libertação da protagonista, inicia-se certo questionamento, no qual se indaga quem realmente está em processo de odisseia - ele na ânsia de sua partida, ou ela na mansidão da sua espera: "Não sabia quem entre os dois era mais sensível à violência. Ele que se havia ido, ela que tivera que ficar. Só com os anos foi compreendendo que se ele ainda vivia tardava a regressar." (Piñon, 1997, p. 99). A notação de tempo "anos" é outro sinal do diálogo intertextual latente no texto, já que Ulisses passa dez anos na Guerra de Tróia e, posteriormente, demora mais dez 
anos para retornar à Ítaca. Em muitos momentos da Odisseia, também se questiona se o herói teria sobrevivido à suas provações, comportamento espelhado pela que a mulher de "Colheita".

A referência textual à guerra é mais uma evidência intertextual do conto de Piñon em relação a Odisseia: "ora o absolvia: porque você precisou da sua rebeldia, eu vivo só, não sei se a guerra tragou você." (Piñon, 1997, p. 99).Uma vez que se sabe que o homem apenas foi viajar e conhecer o mundo, fica clara a intenção da autora de dialogar com o citado poema épico.

Com o retorno do marido, após longa ausência, a tensão dos papéis femininos e masculinos é trazida à luz, norteada pela questão espacial: o espaço expandido, o universo exterior que corresponde ao macrocosmo, é de domínio do homem. Já o espaço contraído do universo interior, o microcosmo, é tradicionalmente de domínio feminino. Mas é, exatamente, na contração do microcosmo que a protagonista concentra toda a sua vitalidade e faz transbordar a narrativa por meio dos mistérios da criação feminina.

Se ele se volta para a esfera pública, domínio da aparência, ela mergulha na esfera doméstica e em seu interior, configurando-se como uma personagem mais complexa e plural, apta a compreender o mistério do qual se constitui o imaginário cultural. Nesse sentido, a narradora de "Colheita" contraria as categorias benjaminianas acerca do narrador viajante e do narrador sedentário, revelando que viagens interiores podem ser tão ou mais ricas do que peregrinações.

Segundo Dumith (2012, p. 242), o conto "Colheita" coloca em cena os narradores de Benjamin, o viajante - que recolhe histórias de terras longínquas - e o sedentário que resgata as histórias próprias da terra em que se fixa:

A figura do narrador só se torna plenamente tangível se tivermos presentes ambos esses grupos. "Quem viaja tem muito o que contar", diz o povo, e com isso imagina o narrador como alguém que vem de longe. Mas também escutamos com prazer o homem que ganhou honestamente sua vida sem sair do seu país e que conhece suas histórias e tradições. Se quisermos concretizar esses dois grupos através dos seus representantes arcaicos, podemos dizer que um é exemplificado pelo camponês sedentário, e o outro pelo marinheiro comerciante. (Benjamim, 2014, p. 214)

Contudo, se Benjamin reconhece certa equivalência entre os potenciais criativos de ambos os narradores, concedendo, no entanto, maior destaque ao narrador viajante, Piñon subverte tal postulado valorizando o narrador que se fixa. 
Semelhante a Odisseia, o reencontro não é efusivo. Se em "Colheita" a mulher faz "da madeira o seu escudo" (Piñon, 1997, p. 100) ao abrir a porta para o marido, Penélope também se defende de Ulisses quando se reencontram. Ulisses até mesmo a acusa de ter um coração de ferro: "Nenhuma outra mulher se manteria afastada com tal dureza do marido que, tendo padecido tantos sofrimentos, regressa no vigésimo ano à pátria." (Homero, 2010, p. 373).

Análogo ao texto grego, é o homem que primeiro se dirige à mulher. Ele quebra o silêncio no momento do reencontro, pois o discurso sempre fora seu domínio, ainda que confie a ela a habilidade de tecer as palavras e reparar seus descuidos e "omissões fatais".

Disse-lhe: voltei. Também poderia ter dito: já não te quero mais. Confiava na mulher; ela saberia organizar as palavras expressas com descuido. Nem a verdade, ou sua imagem contrária, denunciaria seu hino interior. Deveria ser como se ambos conduzindo o amor jamais o tivessem interrompido. (Piñon, 1997, p. 100)

As personagens, ao recobrarem o fio de sua rotina, não podem ignorar as transformações que o hiato temporal provoca. O bordado ganhou novas linhas, cores mais intensas. O homem, entretanto, não teve sensibilidade suficiente para analisar esse matiz de cores novas, frescas e simplesmente retomar a vida, então, passa a interrogar sobre o abismo de tempo que os separara, insiste no espaço vazio da trama: "Onde estive então nesta casa, perguntou ele, procure e em achando haveremos de conversar. O homem sentiu-se atingido por tais palavras. Mas as peregrinações lhe haviam ensinado que mesmo para dentro de casa se trazem os desafios" (Piñon, 1997, p. 101)

O homem não percebe que esteve em cada mínimo detalhe da casa e em cada atitude da mulher. Ela transformou sua existência em um tributo ao marido, porém ele não compreende a sua singeleza e busca por um tributo material: "Debaixo do sofá, da mesa, sobre a cama, entre os lençóis, mesmo no galinheiro, ele procurou, sempre prosseguindo, quase lhe perguntava: estou quente ou frio." (Piñon, 1997, p. 101).

O protagonista inicia, então, uma nova odisseia em busca de si mesmo, duplicado no retrato. Ele, que acabara de retornar de uma odisseia expandida, empreende uma odisseia microscópica dentro do seu lar. A mulher mantém-se coerente com sua postura anterior, assim como não interferiu em sua partida também se mantém calada durante essa procura: "A mulher não seguia suas 
buscas, agasalhada em um longo casaco de lã, agora descascava batatas imitando as mulheres que encontram alegria neste engenho." (Piñon, 1997, p. 101). Ela permanece fiel aos ofícios do lar. Como quando o marido partiu, ela se voltara para a intimidade do ambiente doméstico, continua a explorar o prosaico, enquanto ele realiza a microscópica busca.

Ao encontrar o retrato entre cacos em cima do armário o homem ralha com a mulher, duvidando de sua fidelidade, porém ao compreender a ação ele mesmo decide rasgá-lo. Segundo Moreira (2014, p. 43), a ação de rasgar o retrato é uma negação simbólica de tudo que ele fora antes da partida e, portanto, rompe com ordem patriarcal. Para a autora esse gesto marca a disposição dele de adotar o mundo prosaico apresentado pela companheira.

A mulher o aguarda, novamente, na cozinha. Ali está a síntese da sua espera. Foi esse o palco da sua odisseia rumo à intimidade do lar e é ali que ela resolve repetir seus afazeres diários para mostrar a ele a sua presença em cada gesto: "Fez a comida, se alimentaram em silêncio. Depois limpou o chão, lavou os pratos, fez a cama recém-desarrumada, tirou o pó da casa, abriu todas as janelas quase sempre fechadas naqueles anos de sua ausência" (Piñon, 1997, p. 101) É ali que ela germinou a saudade que enfim pode ser colhida no reencontro. Devido ao papel de relevo dado à cozinha na narrativa, Dumith (2012) considera que a mulher mescla características de Penélope e de Héstia, deusa guardiã do fogo sagrado do Olimpo.

Vale ressaltar que a fidelidade dela não encontra eco: o marido tal como Ulisses possuíra outras mulheres durante a viagem. Ulisses foi amante de Calipso e Circe, e o homem de "Colheita" teve amantes, sem que se individualizassem: "Não deixando que lhe contasse, sim que as mulheres, embora louras, pálidas, morenas e de pele de trigo, não ostentavam seu cheiro, a ela, ele a identificaria mesmo de olhos fechados." (Piñon, 1997, p. 102). Mesmo os homens das duas narrativas preferindo as esposas, sua "infidelidade" acentua a fidelidade de suas mulheres, que, apesar do tempo, preservaram o contrato do casamento.

A mulher, nesse momento, assume o discurso e a sua odisseia íntima sobrepõe-se à dele: "E ela, não deixando ele contar o que fora o registro da sua vida, ia substituindo com palavras dela então o que ela havia sim vivido. E de tal modo falava como se ela é que houvesse abandonado a aldeia (...) sua riqueza era enumerar com volúpia os afazeres diários a que estivera confinada desde a sua partida" (Piñon, 1997, p. 102) 
Ao longo do seu relato, ela se torna um sujeito livre que constrói a própria história e que se libertou parcialmente dos valores patriarcais que a tornavam submissa, conforme já assinalado pela crítica. Apesar de sua transformação, Souza e Cavalcante (2012) observam que, por não romper o laço matrimonial, a protagonista ainda se mantém na ordem patriarcal. Em "Colheita" parece estar em jogo a tensão entre moderno e arcaico, entre ruptura e permanência, espelhada no comportamento da protagonista que, por um lado, liberta-se pela criação e, por outro, repete traços do socialmente estabelecido.

Em contrapartida, a sua espera foi uma opção livre e não uma convenção social que, por ser mulher, ela deveria cumprir. Sua aventura diária foi lidar com essa escolha e, ainda, libertar-se da autopiedade:

inventara um prato talvez de origem dinamarquesa, e o cobriu de verdura, diante dele fingia-se coelho, logo assumindo o estado que the trazia graça, alimentava-se com a mão e sentia-se mulher; como também simulava escrever cartas jamais enviadas pois ignorava onde encontrá-lo; (...) seu modo de descascar frutas, tecendo delicadas combinações de desenho sobre a casca, ora pondo em relevo um trecho maior da polpa, ora deixando o fruto revestido apenas de rápidos fiapos de pele. (Piñon, 1997, p. 102)

Nesse fragmento se evidencia que a libertação da mulher se dá por meio da criação. Ela não apenas tece a saudade e a espera, tece receitas, tece escrita (cartas) e borda em cascas de fruta. Dumith (2012) destaca que a personagem trabalha com fios perecíveis ao invés dos fios duradouros da tecelagem, o que revela um paradoxo, já que ela é senhora de seu tempo. Ampliando tal reflexão, não se pode ignorar que a mulher é uma tecelã do prosaico e que as tarefas cotidianas não são distendidas no tempo, mas diariamente renovadas.

Ela manifesta sua revolução na colher de pau, na caneta e na ponta da faca, assim como Penélope se liberta em seu tear. É uma tecelã completa, pois tece tudo o que precisa para ser feliz no ambiente doméstico. A mulher, ao assumir o discurso, atinge o ponto culminante da sua expansão:

E tanto ela ia relatando os longos anos de sua espera, um cotidiano que em sua boca alcançava vigor, que temia ele interromper um só momento o que ela projetava dentro da casa como se cuspisse pérolas, cachorros miniaturas, e uma grama viçosa, mesmo a pretexto de viver junto com ela as coisas que ele havia vivido sozinho. Pois quanto mais ela adensava a narrativa, mais ele sentia que além de a ter ferido com o seu profundo conhecimento da terra, o seu profundo conhecimento da terra afinal não significava nada. Ela era mais capaz do que ele de atingir a intensidade, e muito mais sensível.(Piñon, 1997, p. 103) 
Graças ao relato da esposa, ele finalmente compreende que teria tido tudo ali e reconhece o valor da companheira. A intensidade da experiência vivida pela mulher o faz compreender a vacuidade das experiências que ele tivera:

À medida que as virtudes da mulher o sufocavam, as suas vitórias e experiências iam-se transformando em uma massa confusa, desorientada, já não sabendo ele o que fazer dela. (...) Nada fizera senão andar e pensar que aprendeu verdades diante das quais a mulher haveria de capitular. No entanto, ela confessando a jornada dos legumes, a confecção misteriosa de uma sopa, selava sobre ele um penoso silêncio. (Piñon, 1997, pp. 103, 104.)

A mulher encontra o prazer libertador de assumir voz para expressar sua opinião e construir seu destino. Deixa de ser a ouvinte e leitora passiva e se torna criadora de histórias, e, sobretudo, da própria história, descobrindo uma espécie de encantamento, parecido à alquimia que ela experimentara na cozinha, agora, pode ser alquimista com as palavras: "Ela não cessava de se apoderar das palavras, pela primeira vez em tanto tempo explicava sua vida, tinha prazer de recolher no ventre, como um tumor que coça as paredes íntimas, o som da sua voz" (Piñon, 1997, p. 104)

Segundo essa relação da personagem com a criação discursiva, o título "Colheita" pode ser reinterpretado. "Lego" em latim é colher, de modo que colheita e leitura se aproximam. O próprio título do conto antecipa o papel da mulher enquanto tecelã de histórias: semeia e colhe, escreve e lê, tece e cozinha destinos e discursos. No desfecho, o homem tenta recuperar o mundo interior, seguindo os passos do feminino:

ele foi arrumando a casa, passou pano molhado nos armários, fingindo ouvi-la ia esquecendo a terra no arrebato da limpeza. E, quando a cozinha se apresentou imaculada, ele recomeçou tudo de novo, então descascando frutas para a compota enquanto ela lhe fornecia histórias indispensáveis ao mundo que precisaria apreender uma vez que a ele pretendia dedicar-se para sempre. Mas de tal modo agora arrebatava-se que parecia distraído, como pudesse dispensar as palavras encantadas da mulher para adotar afinal o seu universo. (Piñon, 1997, p. 104)

Ele também adere à repetição, valorizando a rotina e o prosaico em uma analogia ao movimento circular do mito, ainda que o enredo se organize de maneira cronológica e, portanto, não configure uma organização cíclica. Ao adotar o universo da mulher, o homem reconhece sua superioridade no contato com a vida e, ao optar 
por assumir as tarefas domésticas, reconhece nos valores patriarcais uma força limitadora.:

\begin{abstract}
A atitude do marido diante do comportamento inusitado da esposa também surpreende: o ato de ele tomar a vassoura e lançar-se à limpeza, num desejo desesperado de vivenciar as mesmas coisas que a esposa teria vivido devotando-se às atividades domésticas, vem complementar esse seu novo olhar em relação à mulher. (Zolin, 2008, p. 18)
\end{abstract}

O desfecho repousa sobre o equilíbrio: Não há mais uma figura impondo-se sobre a outra no espelho, ambos desejam caminhar lado a lado, cooperando um com o outro e vivendo em paz. A tese de Virginia Woolf em "Um Teto Todo Seu" (2004) reflete uma busca da verdadeira igualdade de gênero, que conflui no percurso narrativo de "Colheita". Nele, homem e mulher alcançam o equilíbrio, "completando-se" com suas diferenças, já que, conforme analisa Woolf (2004), a divergência de opiniões funciona como fertilizadora criativa do relacionamento homem-mulher ${ }^{65}$.

O título "colheita" é mais uma vez ressignificado no desfecho. Para Soares (1997, p. 148 APUD Dumith, 2012, p. 248), o conto de Piñon celebra a construção de um novo espaço-tempo fecundado pelo encontro efetivo dos universos masculino e feminino.

Nesse sentido, consideramos que a colheita corresponde à ambivalência do fruto, resultado da interação das polaridades masculina e feminina. Tal título, portanto, sintetiza todo o percurso do conto, já que pressupõe em um primeiro momento o papel mais ativo do homem, para semear, em um segundo momento o da mulher, metaforizada em mãe terra, para germinar em espera que permite o crescimento, e só então - depois de um hiato temporal - a colheita é possível. Analogamente, em um primeiro momento, o homem sobrepõe-se à mulher, em um segundo momento, ela se impõe sobre ele e o seu desfecho tende para o equilíbrio das forças masculinas e femininas, a colheita.

Podemos ainda notar o retorno de procedimentos do mito, analisados por Mielietinski (1987), na fatura da obra. Assinalamos na análise a presença da atmosfera atemporal, a circularidade e a reiteração de gestos e rotinas que remetem à repetição mítica. Há que se notar que, apesar de as metáforas não serem recorrentes no texto, o discurso metafórico permeia a macroestrutura do conto e a

${ }^{65}$ Cf. WOOLF, Virginia Um teto todo seu. Rio de Janeiro: Nova Fronteira, 2004, pp. 95-96 
sua linguagem poética, revelando mais um aspecto de seu vínculo com o discurso mítico.

A oralidade - traço da poética mítica - também comparece no interior da narrativa enquanto simulacro, uma vez que a mulher assume, no fim da narrativa, o papel de aedo, cuja função reside em contar histórias a outrem, de modo a provocar o encantamento: "Mas de tal modo agora arrebatava-se que parecia distraído, como pudesse dispensar as palavras encantadas da mulher para adotar afinal o seu universo." (Piñon, 1997, p. 104) Assim, resgata-se no cerne da narrativa a oralidade própria do mito.

Contudo, a complexidade da narrativa de Nélida rompe com a formulação assertiva do mito, um dos elementos de sua poética. A tessitura da narrativa afastase do mundo da oralidade devido à sofisticação da linguagem, ainda que a personagem se manifeste pela fala. $O$ conto, em grande parte, estrutura as frases na ordem direta, mas também ocorre, em algumas passagens, o emprego da ordem inversa: "Pareciam os dois soldados de uma fronteira estrangeira" (Piñon, 1997, p. 97); "Seu nome procuravam banir de qualquer conversa." (Piñon, 1997, p. 98); "Fingia a mulher não perceber seu ingresso casa adentro." (Piñon, 1997, p. 100). Tal deslocamento da ordem quebra o ritmo mantido na maioria das ocorrências frasais, o que denota a fuga da instância oral, configurando-se, então, numa ruptura com o mítico, em uma valoração do aspecto narrativo próprio da escrita.

A autora parece ancorar seu texto no espaço intermediário da estrutura fabular, mesclando o arcaísmo do mito às inovações do conto contemporâneo. $O$ moderno e o arcaico, portanto, coexistem, conforme já discutido amplamente pela crítica. A imprecisão temporal resgata o plano mítico em que passado, presente e futuro fundem-se em um todo atemporal e os poucos dados do contemporâneo, que comparecem textualmente, são a menção à fotografia (retrato passível de ser rasgado) e ao helicóptero, só possível no século XX.

A estrutura social também remete ao universo arcaico. A organização da aldeia, descentralizada, campestre e marginal permite que aspectos da opressão se manifestem. A expressão "marca de boi" (Piñon, 1997, p.98), que inscreveria o nome do homem na pele da mulher, deixa transparecer o funcionamento social retrógrado, em que as mulheres pertencem aos cônjuges. As instâncias da vigilância e do controle comparecem, sobretudo, na relação da aldeia com o casal, no não- 
reconhecimento de seu vínculo afetivo, porque não documentado, conforme assinala Dumith (2012).

Os valores veiculados, entretanto, são de formulação moderna, uma vez que a libertação feminina das estruturas patriarcais e sua tomada de discurso seriam raríssimas antes do século XX. Em contrapartida, ao se imprimir a estrutura fabular, o arcaísmo instaura-se. No choque do arcaico com o moderno, Nélida questiona as construções que sustentam a modernização conservadora ${ }^{66}$ - traço marcante da formação do Brasil. Ainda que a narrativa não desvele o lugar geográfico em que se passa, essa tensão entre arcaísmo e modernidade pode apontar para o interior do país, marcado pelo descompasso entre valores e práticas sociais.

Em suma, a autora parece recorrer à estrutura fabular para imprimir em suas personagens reflexões sobre o humano e, paralelamente, instaurar a modernidade e o seu questionamento por meio da fissura da ancoragem presente. Nélida Piñon, ao criar a sua neo-tecelã, defende a força ancestral que permeia a feminilidade e desenha uma personagem emancipada da opressão patriarcal por sua fecundidade criadora.

\subsection{0 fio da espera}

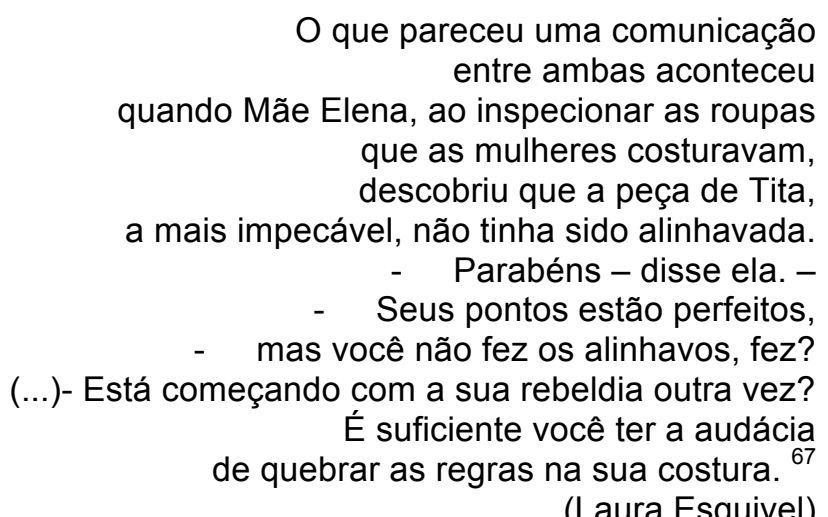

(Laura Esquivel)

O texto "Desenredo" (2001), enquanto articulador da presente pesquisa nos sugere que os demais textos do corpus sejam a ele relacionados em um diálogo constelacional, como proposto na introdução do trabalho. Assim, poderemos

\footnotetext{
${ }^{66}$ SCHWARZ, Roberto. As ideias fora do lugar. São Paulo: Cia das Letras, 2014.

${ }^{67}$ Idem, p. 15.
} 
relacionar os contos em análise partindo do mitema da tecelã e suas nuances reelaboradas em cada um deles.

As narrativas "Desenredo" (2001) e "Colheita" (1997), podem dialogar não apenas pela questão da tecelagem, mas sobremaneira, devido à manipulação discursiva que se faz fundamental nas duas tramas. O fio narrativo no enredo rosiano é manipulado por Jó Joaquim, que reescreve sua história para alcançar a felicidade, por meio da paciência (espera) e da astúcia. Temos, portanto, uma Penélope apequenada e de gênero masculino interferindo no destino para purificar a mulher e desfazer o adultério.

Em "Colheita" (1997) o percurso narrativo está espelhado em relação ao conto rosiano. Temos também a imagem da espera, ainda que mais paradigmática do que a presente em "Desenredo" (2001), contudo a protagonista da narrativa se recusa a interferir do destino e nas escolhas do marido, ela se resigna à espera mesmo já acreditando que o homem fazia uma escolha errada. A partir dessa ausência, ela se reelabora e assume seu poder discursivo para escrever sua própria história.

Em ambas as narrativas é a ausência do amado que faz os protagonistas recorrerem à palavra para a reescrita de suas vidas. Contudo tal contato com o discurso é realizado por vias distintas em cada um. Jó Joaquim precisa da palavra para compor Livíria, palavra plástica e contraditória, que precisa ser adequada ao horizonte de expectativa da aldeia; enquanto, para a mulher de "Colheita" (1997), a relação com a palavra não passa pelo cônjuge: é ela quem sai transformada e se liberta, reescrevendo-se por meio do verbo. Ela mesma é uma mulher-palavra que reconfigura seu universo simbólico, portando a ambivalência da escritura e da palavra poética: ao reescrever a si ela é, simultaneamente, processo e matéria de sua criação.

De certo modo, a mulher de "Colheita" (1997) é também pharmakon, como Livíria, mas a faceta que se sobressai é a da palavra no papel de cura e transformação, ficando oculta as potências destruidoras do veneno. Desse modo, temos mulheres herdeiras de linhagens opostas, enquanto a do conto de Piñon é herdeira de Penélope, a da narrativa rosiana é herdeira de Pandora e das tecelãs fatais, ao tecer enganos e sedução. Paralelamente, Livíria pode ser ainda associada ao homem de "Colheita", uma vez que ambos deixam o espaço da aldeia e depositam seu destino na produção discursiva do outro. 
O tempo fabular igualmente aproxima as duas narrativas, bem como o espaço social da aldeia. $\mathrm{Na}$ quase indefinição temporal, pontuada apenas por breves referências à tecnologia, "Colheita" inscreve-se na estrutura temporal fabular, assim como "Desenredo", em que nenhuma referência ao contemporâneo é realizada, de modo a enfatizar o arcaísmo do sertão brasileiro. As duas narrativas também colocam em cena a estrutura constritiva das aldeias, que ora são "a eterna vigilância", e ora "rejeita o proceder de quem habita terras raras.", revelando o poder opressivo das pequenas comunidades, nas quais a regulagem do outro é prática corrente. Os dois casais são transgressores em relação aos valores postulados pela aldeia e, portanto, são marginalizados.

\subsection{A Moça Tecelã: Os fios libertadores da criação}

Vazo meu discurso sobre elementos de liberdade e escravidão.

Se me foi possivel tecer tapetes, ao menos que me seja facultada esta outra urdidura, de fios semivisiveis, fornecidos em códigos por vezes inescrutáveis.

e, se possivel, que eu chegue ao bordado da fala, supremo requinte de quem maneja agulhas de enredar e prender.

(Nilma Goncalves Lacerda)

O conto "A Moça Tecelã", de Marina Colasanti, narra a história de uma personagem que vive sozinha e tranquila com o seu tear. $\mathrm{O}$ artefato possui poderes mágicos e, nele, ela pode urdir tudo o que deseja: o clima, seu alimento e o que a cerca. Contudo, com o passar do tempo, a solidão começa a ser um peso e a moça decide tecer um marido para Ihe fazer companhia. Ela traça um companheiro nos moldes dos contos de fadas, ele, entretanto, revela-se um tirano, desejando apenas usufruir dos poderes do tear para obter bens materiais. Cansada e sem tempo de tecer seus próprios desejos, a moça vira a lançadeira ao contrário e destece todos os luxos que urdira para o marido. Por fim, destece-o e volta a viver em paz com a natureza e com o tear.

Essa narrativa recebe bastante atenção da crítica $^{68}$, sobretudo, devido à reformulação de valores comumente veiculados pelo conto de fadas. As leituras

\footnotetext{
${ }^{68}$ Alguns artigos que analisam "A Moça Tecelã": "A Moça Tecelã: uma voz dissonantemente transgressora” (2008), Andressa Teixeira Pedrosa; "Tecendo o mundo em palavras: uma analogia à composição literária" (2013), de Katiane Iglesias Rocha Araujo; “O maravilhoso e o insólito nos contos de Marina Colasanti” (2009), de Regina Silva Michelli; "A representação da menina e da mulher no conto de fadas moderno: novos destinos em "Além do bastidor" e "A moça tecelã" de Marina Colasanti" (2005), de Lívia Maria Rosa Soares Diógenes
} 
concentram-se na área da literatura infantil por seu elo com o conto feérico e o maravilhoso e nos estudos de gênero em função da figura feminina emancipada. Alguns trabalhos também destacam o liame da obra com as tecelãs míticas e outros sublinham a dimensão metalinguística do texto.

Nesse conto, as relações entre tecer e narrar apresentam-se de maneira bastante explícita. Ao escolher como protagonista uma mulher que literalmente tece e graças à tessitura cria realidades, Marina evoca as tecelãs míticas quase imediatamente. As tecelãs, conforme já apresentado, destacam-se na cultura grega na qualidade de urdidoras do destino.

A associação da tecelã com a escritora é justificável uma vez que ambas trabalham com destinos (reais ou fictícios) e lidam com o textum, a primeira no âmbito têxtil, a segunda, na esfera textual, dentre outros aspectos já apresentados. Tal relação também parece fundamentada no próprio vocabulário partilhado por essas categorias: ponto, linha, fio (da meada), trama, enredo/enredar: "O tear, objeto do tecer, pode ser comparado à pena, no escrever. A feitura do tapete remete à própria criação literária, metaforicamente. A imagem feminina presente no conto é a de uma mulher capaz de criar seu próprio mundo e, ainda, inventar outros." (Araújo, 2013, p.07)

Aparentemente, estamos na esfera do conto de fadas, contudo em "A Moça Tecelã" deparamos com a Odisseia da escrita, subjetiva, mas tão desafiadora quanto uma viagem. A jornada aqui é para dentro de si, a construção é de mundos interiores e múltiplos. A espera existe por causa do plano da criação, que por não ser linear depende de algo mais do que o desejo de criar.

A voz de Marina Colasanti em "A Moça Tecelã" desenvolve uma trama que leva o leitor a navegar pelas águas do arquétipo do fiar: uma narrativa que resgata o mitema da tecelã, que na surdina tece o tempo e o destino humano. Colasanti apropria-se das lãs invisíveis e constrói uma história, que esconde leques de significação. Ela constrói um enredo atemporal, em diálogo com a poética do mito que resgata e reatualiza as fiandeiras gregas.

Buenos Aires de Carvalho; “No (des) tecer do texto: a marca das relações de gênero no fio do destino feminino em A moça tecelã de Marina Colasanti" (2014), de Elizabete Gerlândia Caron Sandrini; "Desfiando as amarras patriarcais: a subversão do mito de Penélope em "A Moça Tecelã” (2011), de Maria Cláudia Simões; "Reencantos e Ressignificações no conto de fadas contemporâneo: Uma análise de A Moça Tecelã." (2011), de Maria Helena Beluque e Célia Fernandes; "A tessitura da escrita: do mito à expressão pela arte" (2008), de Eliane Campello; "Violência Simbólica e estrutura de dominação em A Moça Tecelã, de Marina Colasanti." (2007), de Lúcia Osana Zoli, Mirele Carolina Jacomel, Cristian Pagoto e Soraya Molinari. 
A estrutura empregada por Marina Colasanti é a dos enredos feéricos, contudo, ela subverte a voz de submissão da figura feminina, tão recorrente nesse gênero, criando uma tecelã que tece sua própria liberdade e, portanto, rompe com o conto de fadas tradicional.

Nesse sentido, a primeira linha de leitura possível evidencia o imaginário infantil e flui com curso linear, seguindo o modelo dos contos de fada com suas torres altas, príncipes encantados e agulhas de condão. O enredo é simples, ainda que se revele ao final transgressor, uma moça possui um tear mágico e nele tece tudo o que precisa para sobreviver: "Nada Ihe faltava. Na hora da fome tecia um lindo peixe, com cuidado de escamas. $E$ eis que o peixe estava na mesa, pronto para ser comido. Se sede vinha, suave era a lã cor de leite que entremeava o tapete. $E$ à noite, depois de lançar seu fio de escuridão, dormia tranquila (...) Tecer era tudo o que fazia. Tecer era tudo o que queria fazer" (Colasanti, 2009, p. 10)

Mas a moça está só. Então decide tecer um príncipe encantado para amenizar a sua solidão:

\begin{abstract}
Apesar dessa sensação de plenitude, instala-se a solidão no íntimo da personagem e um marido é tecido. A expectativa da moça, entretanto, se frustra com o ser por ela criado: subjugada em sua criatividade aos ditames do marido, que dela continuamente exige bens materiais, apossa-se da heroína o desejo de ser de novo sujeito de sua história, tecelã de seu destino: basta-lhe puxar o fio - não de Ariadne, mas das Moiras - para que o marido seja desconstruído, desaparecendo da vista e da vida dela, desfecho que surpreende o leitor pela rapidez com que acontece na narrativa: (Michelli, 2009, p. 221)
\end{abstract}

Porém, o príncipe logo se converte em ditador, impedindo-a de tecer livremente. A tecelã passa a ser escrava daquele de quem pensara obter amor. A figura masculina passa a controlá-la, ainda que o poder sobre o tear seja da mulher:

A construção das personagens nesse texto mostra que existe uma estrutura social dominante que predomina na maioria das sociedades. As mulheres, no contexto cultural, entendem o casamento como um passo fundamental para sua vida e essa relação matrimonial, então, se segue do que Bourdieu (2007) denomina "violência simbólica" em que o sexo feminino sempre se submete ao masculino. Essa postura perpassada culturalmente às mulheres tem relações com os postulados da casa patriarcal, em que elas deixam de pertencer ao espaço dominado pelo pai para comporem o universo de domínio do marido. (Zolin et alii p. 85)

Então, contrariando a lógica das narrativas féericas, ela decide destecer o enredo já conformado e "desentristecer", encontrando o "felizes para sempre" na vivência da sua autonomia:

Desta vez não precisou escolher linha nenhuma. Segurou a lançadeira ao contrário, e jogando-a veloz de um lado para o outro, 
começou a desfazer seu tecido. Desteceu os cavalos, as carruagens, as estrebarias, os jardins. Depois desteceu os criados e o palácio e todas as maravilhas que continha. E novamente se viu na sua casa pequena e sorriu para o jardim além da janela (Colasanti, 2009, p. 11)

Ambas, fada e tecelã interferem no fado, do latim fatum ${ }^{69}$, raiz comum do destino e da fada, varinha e tear recriando a linearidade do real. Nessa direção, como afirma Brunuel (2005), a imagem da fada desdobra-se da Moira, e daí herda o seu poder de interferir no destino. Para ele a fiandeira e seus utensílio possuem poderes mágicos quase intercambiáveis e essa potência de transformação encantatória é resgatada pela figura das fadas.

Durand (2002) também revela a proximidade existente entre o fio e a feitiçaria e a correlação etimológica entre "ligar" e "enfeitiçar", o que confere certa ambiguidade aos elementos de fiar e aos processos mágicos ${ }^{70}$. A fada resgata a imagem da criação e da transformação ligadas à tecelagem:

$O$ ato de tecer é uma metáfora de transformação, e transformação é o trabalho da mulher. A mulher da casa tece linho ou lã fazendo um fio com o qual se faz roupas; depois converte roupas velhas em retalhos, retalhos em colchas ou tapetes, e colchas ou tapetes em arte. Ela transforma, ou costumava transformar, o grão em farinha, a farinha em pão, que se torna alimento para sua família. É um meio de alcançar uma forma interior de transformação. Uma vez que a magia da mulher é uma metáfora para o crescimento natural. (Gould p. 19 APUD Carvalho p. 79)

A moça torna-se mágica através do artefato e só com sua habilidade pode preencher a solidão que é própria do ser humano e só passível de redução a partir do interior. Ela, ao tecer e bordar, vai criando a realidade, a si mesma e faz sua própria história; é ela quem decide o pedaço da história em que o príncipe encantado aparece e o tece segundo seu desejo, embora se deixe levar pelo senso comum:

A construção das personagens no conto se dá de forma simples e direta. Como nos contos tradicionais, pouco se sabe sobre a Moça Tecelã̃, focalizando apenas sua atividade principal e sugerindo alguns de seus desejos. Por centralizar a descrição nos desejos da personagem e não em suas características físicas, sabemos mais sobre seu companheiro, que foi um desejo dela, do que, propriamente, da protagonista (Beluque e Fernandes, 2011, p.176)

Essa imagem é muito contundente, uma vez que, ao tecer seu próprio destino, a personagem coloca-se na esteira da linhagem das fiandeiras míticas - As

\footnotetext{
${ }^{69}$ COELHO, Nely Novaes. O conto de Fadas: símbolos, mitos, arquétipos. São Paulo: Paulinas, 2008, p. 78.

${ }^{70}$ Gilbert Durand, As Estruturas Antropológicas do Imaginário, 2002, cf. p. 108.
} 
Moiras - as quais o destino de todos os mortais estava sujeito. E também se afilia a Ariadne - cujo novelo liberta Teseu - pois graças ao fio se liberta do próprio labirinto interior.

Semelhante ao referencial mítico de Penélope, o destecer aparece como artifício astucioso para alcançar a felicidade. Contudo, o conteúdo do mito é reinventado, ao invés de ser citado para reforçar o paradigma da mulher eternamente fiel a seu homem, inverte-se a meta e surge a emancipação feminina e a autonomia diante do companheiro. Podemos considerar, então, a protagonista como uma neo-Penélope que subverte a mensagem simbólica da submissão, pois está conformada em um contexto histórico-social distinto, que exige novos papéis das figuras femininas. Tal voz feminina apresenta-se de modo muito peculiar no texto. Essa Penélope ao avesso não espera seu homem, mas o cria.

O paradigma da esposa exemplar (porque é fiel-fio), que construiu a expectativa do Ocidente acerca da mulher, dá espaço à ressignificação: a mulher submissa para a mulher independente, colocada no mesmo patamar do homem. Se em Guimarães foi Adão dormir, e Eva nascer ${ }^{71}$, em Colasanti foi o príncipe partir para a mulher amanhecer e se cobrir de luz própria. É graças à "partida" do homem, definida por que ela, que a moça acorda e renasce. Percebe-se aí que as personagens analisadas até então - Jó Joaquim, a mulher e a Moça Tecelã configuram-se na ausência dos amados e só por meio dessa distância conseguem, efetivamente, tecer narrativas e alcançar o domínio de seu destino.

O novo papel feminino de tecer o próprio destino é desvendado na transformação do príncipe em homem comum, desmistificando a superioridade do masculino. O homem, ao invés de proporcionar a sonhada (e irrealizável) completude para a tecelã, acaba apresentando-lhe a violência simbólica, como assinado por Simões (2011, p. 12) na esteira de Foucault. Segundo a autora, percebem-se elementos dessa violência uma vez que o marido, mesmo sem utilizar a força física, explora a jovem e a submete a seus desmandos.

A opressão é sentida pelo tom imperativo do marido, que ignora os sonhos da tecelã e deseja apenas a satisfação de seus caprichos. O homem não dirige nenhuma palavra carinhosa à companheira e, no momento de escolher um lugar para que ela se instale, opta por deixá-la na torre mais alta, priorizando a "proteção"

\footnotetext{
${ }^{71}$ Cf Rosa, J. Guimarães. “Desenredo”, 2001.
} 
do tear à sua companhia. Conforme Simões (2011, p. 13), o ato de retirar da mulher o poder de decidir o seu espaço na casa enfatiza a opressão, já que sua vontade é tolhida até mesmo na esfera doméstica.

A costureira de Marina, não tece a mortalha do marido, mas a ele próprio e a si, depois revela o avesso do bordado, revertendo o mecanismo arquetípico do conto de fadas, em que a felicidade da princesa está condicionada ao casamento. Para ela, a união vai pouco a pouco se tornando penosa: "E tecendo, ela própria trouxe o tempo em que sua tristeza lhe pareceu maior que o palácio com todos os seus tesouros. E pela primeira vez pensou em como seria bom estar sozinha de novo" (Colasanti, 2009, p. 13). Nesse sentido, a neo-Penélope configura-se como uma mulher que fia, desfia e desafia, como assinalado pela crítica, ao assumir um papel social de relevo, graças ao qual é possível construir a história feminina, por retalhos: entrelaçando palavras, entretecendo e entretendo seres.

Logo, com a inevitável analogia do som da lançadeira aos golpes em uma máquina de escrever ou teclado de computador, podemos confirmar a real profissão da tecelã, metáfora que liga o tear e a arte literária, ficção por excelência. Ao virar a lançadeira ao contrário e destecer o que havia criado, a moça tecelã inaugura o seu desenredo, não para mudar a imagem do outro, mas para reconfigurar-se sujeito. $O$ conto repousa na metáfora, porque aborda uma instância do falar algo querendo tanger outra instância.

A construção metafórica evoca a poética do mito e representa o lado direito e o avesso do tecido. O que a moça deseja pode ser alcançado pela habilidade; as frustrações e desventuras pedem solução semelhante, isto é, desmancha-se o que não se quer, mas como em uma construção narrativa, na qual se aceita ou se refuta o enredamento do que está sendo contado. Se a personagem agradar, trabalha-se com afinco para que ela se delineie; caso contrário, apaga-se e cria-se outra, talvez mais convincente ou adequada.

Contudo, ainda é possível analisar mais uma dimensão da relação dessa moça com a tecelagem. A metáfora da mulher-escritora não é sintetizada por palavras ou frases, mas cobre com seu véu todo o texto. Essa instância metafórica que perpassa a narrativa comprova também o seu elo com o discurso mítico, cuja base consiste na metáfora: "Assim, jogando a lançadeira de um lado para outro e batendo os grandes pentes do tear para frente e para trás, a moça passava os seus dias." (Colasanti, 2009, p. 11) 
O excerto possibilita, sob um olhar metafórico, a aproximação entre o fazer da tecelã e o fazer da escritora. Tal semelhança pode ser pensada devido à descrição que, em primeira instância, refere-se ao ato de tecer (expressões como lançadeira e pentes do tear, por exemplo), mas que, por analogia, pode ser atribuída ao ato de escrever em uma máquina. Outra passagem suscita essa dúbia análise acerca da acumulação de funções representadas: "Então, como se ouvisse a chegada do sol, a moça escolheu uma linha clara. E foi passando-a devagar entre os fios, delicado traço de luz, que a manhã repetiu na linha do horizonte." (Colasanti, 2009, p.14 )

A presença da homonímia da palavra linha é capaz, no excerto anterior, de provocar um jogo metafórico que implica uma possibilidade dupla: linha da lançadeira; linha da narrativa. Tecer, desmembra-se em duas vias. A escritura assemelha-se ao ato de tecer num ato quase sinônimo. Análoga à escritora, a moça tecelã faz e desfaz seu tecido, constrói uma trama coesa, percorrida por pontos e linhas. Assim como a tecelã, a escritora deve "desmanchar" as palavras que não se adequaram ao texto e, por vezes, até mesmo desfazer todo seu bordado quando, semelhante à moça, a história que pretendia escrever incorre no senso comum: "A busca pela beleza, como a verdade e o bem, é uma qualidade que pode, num sentido, ser predicado de toda de toda grande arte, mas a tentativa deliberada de embelezar pode, em si, somente enfraquecer a energia criativa". (Frye, 2014, p. 239)

Tanto no tear quanto na máquina de escrever, é possível desfazer o que foi feito: no tecido ou no papel, os fios podem ser reconduzidos, cortados, emendados. Como o tecido, a história aceita revisões. A posse da palavra pela mulher é uma questão textual importante, pois A neo-Penélope assume um papel social de relevo através do qual é possível construir a história feminina, uma vez que:

Escrita e linguagem (...) representam poderes e ideologias, e servem para consolidar e garantir determinada supremacia social. Foi dessa maneira que sociedades possuidoras da escrita subjugaram sociedades ágrafas, como também foi o modo encontrado pelos colonizadores para dominar os colonizados. Reprimir a escrita contribuiu para a consolidação das relações de alteridade. Constituiu, assim, uma maneira de evitar que o "outro" adquirisse a chave de um saber que poderia libertá-lo. (Zolin et alii p. 82)

A menção ao ato repetitivo, característica da poética do mito, à rotina da personagem central se dá, logo no início do conto, pelo uso do verbo no pretérito imperfeito. A reiteração se constrói na apresentação da personagem. Exercer suas tarefas diárias de trabalho coincide com a retomada do ofício da natureza, que 
também reinicia seu ciclo. A monotonia imprime o teor da repetição como traço característico da moça:

Acordava ainda no escuro, como se ouvisse o sol chegando atrás das beiradas da noite. E logo sentava-se ao tear. Linha clara, para começar o dia. Delicado traço cor da luz, que ela ia passando entre os fios estendidos, enquanto lá fora a claridade da manhã desenhava o horizonte. Depois linhas mais vivas, quentes lãs iam tecendo hora a hora, em longo tapete que nunca acabava. (Colasanti, 2009, p.11)

A narração não abandona, nos parágrafos seguintes, o uso do imperfeito. Se a reiteração instalada incomodar, pelo excesso, a personagem central, ela, que tem em mãos o poder do tear, revela-se ainda capaz de manipular a natureza, de modo a ajustar, por exemplo, a temperatura: "Mas se durante muitos dias o vento e o frio brigavam com as folhas e espantavam os pássaros, bastava a moça tecer com seus belos fios dourados, para que o sol voltasse a acalmar a natureza." (Colasanti, 2009, p.11)

Quando a personagem se vê completamente instalada na relação previsível de sua rotina praticamente imutável - revelada pelo emprego duplo do gerúndio - ela nota que a realidade precisa sofrer alteração. Segundo Zolin et alli (2007, p. 91) a circularidade do conto também está na sua sugestão de repetição: a moça sente-se só e tece um marido, revolta-se com sua atitude e volta a estar só e ao redescobrir-se solitária provavelmente tentará buscar uma outra companhia reiniciando o círculo. Aqui é possível afirmar que há uma estrutura cíclica pois a primeira linha do conto e a última revelam um espelhamento, com a chegada do sol e o início da tessitura ${ }^{72}$. Os autores afirmam que, nesse sentido, o "felizes para sempre" converte-se em "felizes durante algum tempo.", numa ruptura com o desfecho tradicional dos contos de fadas.

A constatação de que a rotina não mais a preenche, faz a moça estabelecer uma quebra e provocar, aparentemente por vontade própria, a alteração. O emprego do pretérito perfeito comprova que os fatos, outrora revelados pelo imperfeito e agora com seu encantamento esgotados em si, precisam ser revistos. A narrativa comprova, pela alteração do tempo verbal, a transformação pela qual a moça vai

\footnotetext{
72 "Acordava ainda no escuro, como se ouvisse o sol chegando atrás das beiradas da noite. E logo sentava-se ao tear." (Colasanti, 2009, p. 11); "Então, como se ouvisse a chegada do sol, a moça escolheu uma linha clara. E foi passando-a devagar entre os fios, delicado traço de luz, que a manhã repetiu na linha do horizonte." (Colasanti, 2009, p. 13)
} 
passar, em detrimento da solidez de sua vida anterior: repetida, retomada, mas exaurida por esse ciclo. Monta-se, dessa forma, outra etapa recorrente nas expectativas sociais: o casamento.

Tecer era tudo o que fazia. Tecer era tudo o que queria fazer. Mas tecendo e tecendo, ela própria trouxe o tempo em que se sentiu sozinha, e pela primeira vez pensou em como seria bom ter um marido ao lado. Não esperou o dia seguinte. Com o capricho de quem tenta uma coisa nunca conhecida, começou a entremear no tapete as lãs que the dariam companhia. E aos poucos seu desejo foi aparecendo, chapéu emplumado, rosto barbado, corpo aprumado, sapato engraxado.(Colasanti, 2009, p.12)

A repetição, portanto, é estruturante no conto, a composição do narrado vai reproduzindo o enredo dos contos de fadas para posteriormente, desconstruí-lo : a torre, o chapéu emplumado, o peito aprumado, a magia comparecem para instalar um discurso bivocal: os elementos repetem-se para serem desconstruídos na opção da moça pela autonomia. No aspecto linguístico, a formulação simples a partir de conectores coordenativos também recupera o eco da oralidade dos contos infantis para subverter seus valores. Nessa perspectiva, em "A Moça Tecelã", a estrutura fabular comparece de maneira ainda mais evidente. Apesar da ausência da fórmula "era uma vez", estamos diante da estrutura dos enredos feéricos, que se desdobra da estrutura mítica:

Se o maravilhoso parece definir o cenário do começo do conto com o encantamento e a magia que caracterizam a criação de vida pelo ato de tecer da personagem -, ao final, o que se instala é certo estranhamento devido à solução que rompe com o tradicional "viveram felizes para sempre" e apresenta a destruição do outro. (Michelli, 2009, p. 221)

A atmosfera atemporal do mito comparece, bem como a repetição e a metáfora. Segundo Mielietinski (1987), o conto maravilhoso é um desdobramento da estrutura mítica:

As fases principais do processo de transformação do mito em conto maravilhoso: a desritualização e dessacralização, o debilitamento da fé rigorosa na autenticidade dos "acontecimentos" míticos, o desenvolvimento da invenção consciente, a perda da concretude etnográfica, a substituição dos heróis míticos por homens comuns, do tempo mítico pelo tempo fabular indefinido, o enfraquecimento ou a perda do etiologismo, o deslocamento da atenção dos destinos coletivos para os individuais e dos cósmicos para os sociais, fato ao qual está relacionado o surgimento de uma série de novos temas e algumas limitações estruturais. (Mielietinski , 1987, pp. 309, 310)

Em "A Moça Tecelã", podemos notar a substituição do herói pelo homem comum na figura do esposo tirano. Já não temos um ser elevado capaz de grandes feitos, encontramos um herói "burguês" apequenado e medíocre movido, pela 
materialidade. Também se nota a dessacralização no uso do tear não para a criação de vida, mas, sim, para a produção acelerada do capital:

Levando em consideração as ponderações realizadas no início da análise sobre a visão sociológica e histórica da produção têxtil, poderemos sugerir, substancialmente, que a questão do tempo, marcada pelo ritmo apressado, pode relacionar-se também às imposições capitalistas, em que a produtividade desenfreada altera a condição temporal dos sujeitos. (Beluque e Fernandes, 2011, p.178)

A narrativa, além de dialogar com o mito das fiandeiras e a estrutura dos contos de fadas, parece comportar ecos de "A cortina da babá Lugton", de Virginia Woolf. A narrativa escrita entre 1922 e 1925, anterior a de Marina, ressoa em " A Moça Tecelã", para atestar o alcance da retomada do mitema da tecelã, que não está restrita à literatura brasileira e que faz do conto mais um elo de diálogo textual. Em Woolf (2009), a protagonista, Babá Lugton, adormece enquanto costura uma cortina para a sala de visitas de mrs. Gingham, e, aí, seu bordado ganha vida própria:

com o dedal no dedo ainda esticado para cima; e a linha de algodão, enfiada na agulha, caindo solta; ela roncando, roncando; e no seu colo, cobrindo todo o avental, um grande pedaço de pano azul com figuras. Os animais dos quais se cobria o pano não se moveram senão quando a Babá Lugton roncou pela quinta vez (...) o pano azul tornou-se ar puro; agitaram-se as árvores; podia-se ouvir o rumor da água do lago; e ver as pessoas se movimentando na ponte e acenando das janelas com a mão. (Woolf, 2009, p. 225).

O ato de tecer não produz apenas ficção, mas também uma "realidade" dentro da narrativa, conforme propõe o texto de Colasanti. Ambas as tecelãs produzem com suas agulhas um universo, que, para a tecelã de Colasanti, é sua própria subsistência, mas, para a Babá Lugton, a costura gera um mundo ao qual ela está alheia, com seu funcionamento próprio, criado por ela, mas autônomo:

Babá Lugton estava dormindo. Tinha roncado alto. Deixado despencar a cabeça, tinha empurrado os óculos para a testa; sentada ali tão perto da lareira, com o dedal no dedo ainda esticado para cima; e a linha de algodão enfiada na agulha, caindo solta; ela roncando, roncando; e no seu colo, cobrindo todo o avental, um grande pedaço de pano azul com figuras.

Os animais dos quais se cobria o pano não se moveram senão quando Babá Lugton roncou pela quinta vez. Uma, duas, três, quatro, cinco - ah, a velha enfim pegou no sono. O antílope fez um sinal para a zebra; e a girafa abocanhou uma folha na extremidade da árvore; todos os animais começaram a se mexer e aprumar-se. Pois o desenho que enfeitava o pano azul era constituído por bandos de animais selvagens, abaixo dos quais havia um lago e uma ponte (...) (Woolf, 2005, p. 225)

Nesse sentido, podemos aproximar o bordado da Babá Lugton da criação de uma história ou de um livro, uma vez que o processo narrativo depende do autor 
para ser configurado, mas, depois de pronto, transcende ao autor e adquire uma existência independente. A narrativa de Woolf também reforça a hipótese da tecelagem como criação, e portanto, evoca a figura mítica das Moiras. O leitor encontra a Babá no meio do processo de fiação, urdindo o fio da vida, contudo, resta a incógnita: após o fio do bordado ser cortado aquele reino de Millamarchmantopolis continuará a ter existência? Tal problemática igualmente aparece em um outro conto de Colasanti, "Além do Bastidor", no livro Uma ideia toda azul (2013).

Aí, uma irmã mais nova borda um jardim em um bastidor , e com o passar dos dias, o bordado ganha dimensão "real" e a menina desce até o bordado para brincar. Ela então passa a bordar o que gostaria de ver no jardim, descendo até ele pela linha solta - marca das possibilidades ainda existentes do bordado. Contudo, em uma tarde, a irmã mais velha vê a imagem de uma menina no bastidor, ainda não bordada, apenas um risco muito bonito: "Bordou os cabelos, e o vento não mexeu mais neles. Bordou a saia, e as pregas se fixaram. Bordou as mãos, para sempre paradas no pescoço da garça (...) Então bordou a fita dos cabelos, arrematou o ponto, e com muito cuidado cortou a linha." (Colasanti, 2013, pp. 16 e 17). O corte da linha, consoante ao mito das Moiras, equivale a morte da personagem e do universo ficcional.

Segundo, Carvalho (2015), essa narrativa também mostra uma mudança na visão sobre a menina, que espelha as novas conquistas da mulher na sociedade:

.O leitor percebe que tudo aquilo que fora construído não era somente visível a ela, sua irmã percebe os resultados do trabalho da menina e entende que a nova realidade vai além daquele bastidor.(...). A tecelã que estava aparentemente presa à sua realidade ingressa em um ambiente mágico e perfeito que ela mesma criou, o que demonstra as novas tendências da literatura infanto-juvenil, pois a criança agora ocupa outras funções e protagonizam seus destinos. (Carvalho, 2015, p. 79)

Outro texto de Colasanti que aborda o mitema da fiandeira é "Fio após Fio" que conta a história das irmãs Nemésia e Gloxínia, reelaborando o mito de Aracne. À semelhança da competição entre a deusa Atenas e Aracne, a fim de descobrir quem seria a melhor tecelã, Nemésia e Gloxínia bordam um manto branco que deveria pertencer a uma das duas, instaurando assim a competição. Do mesmo modo que Aracne revelou-se uma tecelã superior à deusa, Nemésia, por ter mais habilidade na arte do bordado, é transformada pela irmã Gloxínia, invejosa de seu dom, em aranha através de uma palavra mágica: "Nemésia ainda teve tempo de 
terminar o ponto e libertar mais uma rosa. Depois transformou-se em aranha." (Colasanti, 2013, p.42)

Gloxínia consegue, enfim, bordar com perfeição, usando a linha produzida pela irmã. No mito grego, Aracne é punida por desafiar os deuses, mas, no conto de Colasanti, a punição recai sobre Gloxínia, que fica presa para a eternidade no casulo de prata da irmã Nemésia, transformada em aranha por Gloxínia. Mais uma vez, Colasanti reelabora o material mítico e subverte a mensagem inicial, valorizando o talento de Nemésia e punindo a inveja da outra.

Todas essas narrativas de Colasanti reivindicam um outro espaço discursivo para a mulher e dá a voz a narradoras, pretendendo subverter a ideia de passividade ocupado pela mulher-tecelã, até o século XIX, a fim de valorizar o fiarescrever como produção criativa de mulheres autônomas que visam a construir um novo paradigma histórico para a feminilidade.

\subsection{Destecer, Desenredar}

Enquanto calas

dobras o medo que te cresce na fala

E a solidão bordas

a ponto de silêncio

(Maria Teresa Horta)

Já as narrativas "Desenredo" (2001) e "A Moça Tecelã" (2013) podem ser aproximadas por suas similitudes, mas, apresentam importantes traços distintivos. Em "Desenredo" (2001), encontramos uma personagem masculina inscrita na linhagem das fiandeiras, espécie de Penélope; em "A Moça Tecelã" (2013), a reelaboração do mitema não se encontra na mudança de gênero, mas na postura da tecelã que pode ser considerada uma "neo-Penélope", mantendo as ações da personagem grega, mas subvertendo seus valores.

Os textos podem ser aproximados também pelo elemento amoroso, que articula ambos os enredos e se revela um ponto fundamental para a ação de tecer e destecer destinos. No entanto, se, em "Desenredo", o ato de destecer é empreendido a fim de obter a confluência amorosa, em "A Moça Tecelã" a ação de destecer marca uma ruptura: A Moça escolhe não manter um relacionamento que a torna infeliz; ao invés de reformar o marido como faz Jó Joaquim com Livíria, ela 
simplesmente o destece, e, com ele, o relacionamento amoroso, afirmando sua autonomia.

Os dois protagonistas reelaboram seus destinos graças à palavra: a moça por meio da escrita e Jó Joaquim via oralidade. Porém, Jó Joaquim busca os arquétipos e o final feliz, reelaborando a amada, Livíria; já a protagonista de Marina Colasanti rompe com o senso comum e opta por um final igualmente feliz, mas sem o enlace amoroso, reinventando a si mesma enquanto figura livre e senhora das propriedades mágicas de seu tear. Em suma, a análise de "Colheita" e "A Moça Tecelã" revela uma nova esfera de domínio do feminino, que se encontra e se liberta por meio da palavra poética. Essas mulheres traduzem aspectos fundamentais do imaginário feminino, sobretudo, por serem metonímias de sua tomada de discurso, cifrada na tecelagem e na culinária.

$\mathrm{Na}$ literatura brasileira, temos mulheres sedutoras, misteriosas e que lutam com as armas doméstica contra a reificação de suas irmãs e filhas, utilizando as armas por meio das quais tentaram aprisioná-las para escrever com letras garrafais e caligrafias delicadíssimas a história de sua libertação. 


\section{Penélope na cidade: entre Ítaca e o asfalto}

Quando Ulisses chegar

A sopa estará fria.

Myriam Fraga, "Penélope"

Sopa fria, asfalto, assassinato. Nesse capitulo final esgarçam-se as malhas do mito e se reduz a trama dourada a retalhos puídos. Em Dalton Trevisan, não há espaço para o sublime, resta uma sombra, uma lembrança desgastada de Penélope, das moiras e de Ariadne, quase apagadas em meio ao caos da cidade.

Nos contos de Dalton Trevisan, as tecelãs são inseridas no meio urbano e, portanto, trazidas para um espaço degradado, muito distante do idílio mítico-heroico das obras homéricas. Esse dado será central em nossa análise, posto que apequena o mito, confinando-o no universo burguês e no comezinho mundo urbano. Assim, parece que os contos paralelamente invocam e corroem a narrativa mítica, ao reencená-la em um ambiente que é quase ruína: "A força dessa prosa está em recortar tão cruelmente situações exemplares que o leitor acaba sem saber ao certo se tem pela frente o mais imediato dos realistas ou o mais sombrio e frenético dos expressionistas". (Bosi, 1997, pp. 18, 19)

$\mathrm{Na}$ obra de Dalton Trevisan, a vida cotidiana na cidade e os personagens marginalizados são motes recorrentes. Consoante à crítica, Dalton irá compor a sua obra a partir de tipos humanos que se destacam por seus traços peculiares, sejam eles étnicos, sexuais ou comportamentais. Com seu olhar arguto, Dalton cristaliza instantâneos e se revela cronista do trivial e do subterrâneo. Segundo o crítico, Leopoldo Comitti, o escritor "procura frisar sempre a origem de seus contos: o cotidiano da cidade, filtrado de conversas entreouvidas e noticiários de jornal." (Comitti, 1996 p. 82)

A narrativa crua e concisa do autor reafirma sua busca pelo asfalto e por todas as vicissitudes do homem moderno, que se defronta com a solidão e a ruína dos espaços urbanos:

Outro é o sentido da concisão nas histórias de Dalton Trevisan. Aqui, a obsessão do essencial parece beirar a crônica, mas dela se afasta pelo tom pungente ou grotesco que preside à sucessão das frases, e faz de cada detalhe um índice do extremo desamparo e da extrema crueldade que rege os destinos do homem sem nome na cidade moderna. (Bosi,1997, p.17) 
Nesse sentido, a linguagem rebaixada espelha o mundo decadente que 0 autor procura traduzir, revelando o papel basilar em sua poética: "A representação formal do mundo de Dalton Trevisan se faz então através de uma linguagem rebaixada que o autor desgasta e explora com esmero e rigor, reduzindo-a ao mínimo, ao osso, tiro no coração do leitor." (Waldman, 2007, p. 259),

Por isso, seus narradores nutrem-se do fragmento para narrar: a obra é costurada com retalhos de conversas de bar, recortes de jornal, bilhetes suicidas, cartas anônimas, gemidos e lamentos captados na sinfonia da cidade. O crítico Comitti destaca ainda que a crueza da visão narrativa de Dalton parece indicar uma "denúncia ao sistema vigente" eivado pela repressão e pelo não dito que acompanha sua produção artística nas últimas décadas do século XX.

A crítica ainda destaca a repetição como ponto fulcral da obra de Trevisan, porém não se trata de uma reiteração estanque e sim produtora de novos sentidos: "deixa de ser apenas uma técnica narrativa para se configurar quase como um método de composição. A repetição, seja em relação a personagens, situações, ou mesmo trechos inteiros (...) é um dos aspectos que mais chamam a atenção do leitor."(Ribeiro, 2011, p. 12).

$\mathrm{O}$ autor persegue temas e procedimentos estéticos de maneira quase obsessiva, reescrevendo fragmentos de seus textos no interior da própria obra e marcando-a com personagens que apresentam traços comuns. Parte da sua crítica atribui a repetição a uma relação íntima com os processos de automação e a uma crítica à esfera industrial, embora grande parte dos leitores de Dalton Trevisan veja em tal procedimento estético uma denúncia à angústia do homem moderno, que não encontra alternativas em um mundo marginalizado e decadente senão a repetição acinzentada da rotina. Segundo Waldman (2007, p. 255), a obra de Trevisan desenha um percurso obsessivo, construído a partir da repetição de personagens, situações e temas. Além disso, consoante o crítico, o enxugamento da linguagem no autor revela uma constante inovação que quer iluminar os elementos de seu tempo e de seu lugar. ${ }^{73}$

Os dois textos analisados neste capítulo pertencem ao livro Novelas nada exemplares, primeiro livro de contos do autor, publicado em 1959, cujo título

\footnotetext{
${ }^{73}$ Contando hoje com uma vasta e significativa obra, Trevisan é um escritor programático e obsessivo que traça o itinerário de uma busca incessante, manifestada na repetição de situações, de personagens, de um tema que se multiplica em voltas infindáveis. (...) o enxugamento da linguagem, que sempre se inova, para, por seu intermédio, dar relevo estético e histórico para as coisas de seu tempo e lugar.. (Waldman, 2007, p. 255)
} 
constitui um diálogo irônico com a obra de Cervantes. A presença da tecelagem é notada nas duas narrativas, conforme já assinalado pela crítica:

\begin{abstract}
A mulher suburbana, voltada para os trabalhos manuais e para a paciente espera de um marido ausente, personagem retomada em muitos contos do autor, mostra-se extremamente eficaz para um retorno do texto sobre si mesmo. Dedicadas ao bordado, ao crochê e ao tricô, essas personagens repetem as figuras míticas de Penélope e Aracne e nos remetem diretamente para a etimologia comum das palavras texto e tecido. (Comitti, 1996, p. 84)
\end{abstract}

Dessa maneira, os contos serão introduzidos em nossa teia analítica e a interpretação das questões relativas à tecelagem serão aprofundadas na leitura de "Penélope" e "Ponto de Crôche". Cabe enfatizar que aqui queremos mostrar o mito das tecelãs em uma atmosfera banal, cotidiana, prosaica e ordinária - o que justifica o título do capítulo.

\title{
4.1 A solidão urbana de Penélope
}

\author{
Irmã mais velha \\ Às mulheres de terceira idade \\ As mãos cruzas sobre o ventre \\ e esperas... \\ O fio da idade tecido pelos anos \\ conduz-te os olhos \\ até ao fim do tempo \\ - O que vês, \\ irmã mais velha? \\ (Maria Teresa Horta)
}

No conto "Penélope" (1998), o diálogo intertextual com as matrizes homéricas é evidenciado desde o título da narrativa, que traz à lume o nome próprio da protagonista da Odisseia. Logo no início da trama, o leitor pode perceber que a onomástica não é fortuita, já que nas primeiras linhas o narrador coloca em cena elementos relativos à tecelagem, representados pelas agulhas de tricô: "Naquela rua mora um casal de velhos. A mulher espera o marido na varanda, tricoteia em sua cadeira de balanço. Quando ele chega ao portão, ela está de pé, agulhas cruzadas na cestinha. Ele atravessa o pequeno jardim e, no limiar da porta, beija-a de olho fechado." (Trevisan, 2009, p. 217) 
O primeiro parágrafo ancora o texto em um espaço urbano, promovendo um rebaixamento das personagens homéricas ao trazê-las do mundo do mito para o espaço degradado da cidade. Ainda que o ambiente não seja o da metrópole, posto que, segundo Comitti (1996), a Curitiba de Novelas nada exemplares (1959), escrita e publicada na década de 50, corresponde a uma pequena capital provinciana, mais próxima de uma cidade interiorana, a mudança espacial já dá conta do apequenamento das personagens clássicas.

Dalton também desestabiliza a imagem dos heróis gregos ao atribuir seus papéis a um casal de idosos. Na concepção da Grécia Arcaica, a velhice configurase como uma primeira morte, reiterada pela partida para o Hades. Como a intensa valorização do corpo e da força se fazia presente na tradição helênica, os idosos carregavam o estigma da decadência em que o corpo guarda apenas lembrança dos tempos áureos da juventude. ${ }^{74}$

Assim, revestir Ulisses e Penélope com os mantos da velhice, ocorre pelo deslocamento do locus sublime da epopeia para a crueza do real. Nesse sentido, a carga semântica da narrativa está prenhe de imagens da decadência, que se espraia pelo espaço e pela configuração das personagens. Por outro lado, para além do diálogo com Homero, esse texto ilustra bem a poética de Trevisan, uma vez que, segundo Comitti (1996, p. 83) os tristes casais suburbanos serão recorrentes nos seus textos, bem como a velhice será um de seus núcleos temáticos.

Já na abertura da narrativa, ao lado do tricotar aparece outro traço de Penélope: a espera. A senhora aguarda pacientemente o retorno do marido, que transita pelo espaço externo - oceano microscópico de asfalto e tédio. Contudo, a obra irá também dialogar com os demais textos de nosso corpus. Nota-se desde o

\footnotetext{
${ }^{74}$ Tal concepção pode ser observada na "Canção sobre a Velhice", da poeta grega Safo de Lesbos:

..(das Musas) de colo violáceo os belos dons, crianças,

...a lira melodiosa, amante do canto;

outrora tenra (a pele), agora da velhice...

...e os cabelos de negros se tornaram brancos.

Pesado se me faz o peito, e os joelhos não me suportam-

os que um dia foram ágeis como os de uma corça

Estas coisas lamento sem cansar, mas que posso fazer?

Não é possível, sendo homem, ser desprovido da velhice.

Pois, certa vez, dizem que Eos, a Aurora de róseos braços,

com paixão...carregando Títono aos confins da terra,

Belo e jovem que era ele; mas mesmo a ele alçancou similarmente

A velhice grisalha em tempo- ele que tinha por esposa uma imortal...(o novo fragmento de Safo, Papiro de

Colônia 21351 - Trad Giuliana Ragusa)
} 
princípio a centralidade da terra na narrativa e sua importância na construção do companheirismo do casal:

Sempre juntos, a lidar no quintal, ele entre as couves, ela no canteiro de malvas. Pela janela da cozinha, os vizinhos podem ver que o marido enxuga a louça. No sábado, saem a passeio, ela, gorda, de olhos azuis e ele, magro, de preto. No verão, a mulher usa um vestido branco, fora de moda; ele ainda de preto. ( Trevisan, 2009, p. 215)

Tal proximidade com o cultivo da terra nos remete ao casal de "Colheita", paralelo que será explorado no próximo item ${ }^{75}$. Nota-se que a esposa se ocupa do canteiro das malvas, isto é, das flores, que não podem ser consumidas, enquanto o marido cuida das verduras que podem simbolizar uma agricultura também microscópica. Nesse fragmento, destaca-se igualmente a possibilidade de convívio no trato das atividades domésticas, embora de maneira assimétrica: se o marido enxuga a louça, a esposa a lava, havendo um movimento de equilíbrio de forças.

Note-se que nenhum dos dois é nomeado, sendo tratados apenas como o velho e a velha, escolha geradora de um efeito de generalização: qualquer casal de velhos suburbanos poderiam protagonizar essa história. A natureza ainda comparece em outras passagens do enredo:

Só os dois, sem cachorro, gato, passarinhos. Por vezes, na ausência do marido, ela traz um osso ao cão vagabundo que cheira o portão. Engorda uma galinha, logo se enternece, incapaz de matá-la. O homem desmancha o galinheiro e, no lugar, ergue-se caco feroz. Arranca a única roseira no canto do jardim. Nem a uma rosa concede o seu resto de amor. (Trevisan, 2009, pp. 215, 216)

No fragmento, constata-se uma forte oposição das características da esposa e do marido. Enquanto ela se dedica a atividades voltadas para a ternura e para a criação - zelar pela vida do cão e da galinha, fazer tricô - ele revela não só certa agressividade, mas sobretudo, uma força de destruição ou desmantelamento: desfaz o galinheiro e arranca da terra a última rosa. Vale também ressaltar que a protagonista do conto julga-se incapaz de matar a galinha: "Engorda uma galinha, logo se enternece, incapaz de matá-la", mas a senhora é capaz de matar-se - morte simbólica, observada em seu silenciamento e morte empírica, em seu suicídio.

Como nas demais narrativas do corpus, a referência à palavra será um dos fios condutores para a análise, pois ela aparece na leitura recorrente do jornal, realizada pelo marido, que marca o ritmo monótono da rotina do casal. Porém, a

${ }^{75}$ Cf pp. 143 e 144 da dissertação 
palavra ganha força no enredo, sobretudo, pela aparição de cartas misteriosas cujo remetente é desconhecido, que determina a ruptura com o universo conhecido:

\begin{abstract}
Além do sábado, não saem de casa, o velho fumando cachimbo, a velha trançando agulhas. Até o dia em que, abrindo a porta, de volta do passeio, acham a seus pés uma carta. Ninguém Ihes escreve, parente ou amigo no mundo. $O$ envelope azul, sem endereço. A mulher propõe queimálo, já sofridos demais. Pessoa alguma lhes pode fazer mal, ele responde. (Trevisan, 2009, p. 216 )
\end{abstract}

A descoberta das cartas instaura uma tensão textual crescente. A suspeita do adultério corrói o velho. O ciúme vai tomando conta do até então pacato marido. A desconfiança coloca em xeque a posição de Penélope: Seria a velha a fidelidade das agulhas ou a feiticeira sedutora das palavras? A assertiva "pessoa alguma lhes pode fazer mal", ecoará no último parágrafo, quando o marido torna-se e viúvo e repete para si por meio da voz do narrador "Pessoa alguma Ihe pode fazer mal." ( $p$. 222). A esposa, portanto, apresentava um risco velado de the fazer mal e de fazer mal a si mesma. A solidão pesa como chumbo, assinalada pela simples ausência de um s, que faz a vida do velho mudar do cuidado pelo núcleo familiar para a mera defesa do eu.

O silêncio marca o esgarçamento do tecido do afeto, substituído pela posse e pela agressividade. A turbulência dos relacionamentos amorosos, sobretudo conjugais, constitui traço importante da obra de Dalton Trevisan:

A peleja doméstica é alçada sempre à altura de uma batalha. Joãos e Marias ficcionais são inimigos mortais, forças opostas que, a todo instante, atraem-se e se repelem.(...) as infindáveis discussões domésticas, as brigas cotidianas, o ciúme, a traição e a violência (física ou psicológica) presentes nos contos dramatizam uma das mais antigas guerras da humanidade: a guerra conjugal. A peleja amorosa é uma constante, realimenta uma relação minada que se manifesta como ódio e silêncio.

(...)

Briga-se e se mata por um pedaço de pão. A guerra conjugal na ficção de Trevisan apresenta ao leitor uma sociedade falida e decadente, ainda baseada na tradicional estrutura familiar burguesa, em relações nas quais a violência substitui o diálogo. (Gruber, 2007, pp. 10 e 11)

A autora sintetiza bem a atmosfera que perpassa o conto desde a chegada dos envelopes: a trama de silêncio reflete uma batalha psicológica, espelho de um amor em ruína, cujo distanciamento é ainda maior do que o de Penélope e Ulisses, separados por décadas e mares turbulentos:

Não queima a carta, esquecida na mesa. Sentam-se sob o abajur da sala, ela com o tricô, ele com o jornal. A dona baixa a cabeça, morde uma agulha, com a outra conta os pontos e, olhar perdido, reconta a linha. O homem, jornal dobrado no joelho, lê duas vezes cada frase. O cachimbo apaga, não o acende, ouvindo o seco bater das agulhas. Abre enfim a carta. Duas palavras, em letra recortada de jornal. Nada mais, data ou assinatura. 
Estende o papel à mulher que, depois de ler, olha-o. Ela se põe de pé, a carta na ponta dos dedos. (Trevisan, 2009, p. 216 )

Apesar de as ações cotidianas encontrarem sequência, o compasso do silêncio torna cada pequeno movimento tenso e fragmentado. Ela perde a conta da carreira, ele deve reler os parágrafos do jornal. Como afirma o crítico Leopoldo Comitti: "O silêncio e os subentendidos arrematam a trama, criando pontos de tensão que transformam o texto em um caprichado trabalho de tricô" (Comitti, 1996, p. 84).

A suspeita plaina sobre o par e instaura um sossego terrível, uma quietude inquietante e densa que é replicada do bater seco das agulhas e no farfalhar do jornal. O silêncio é tão penetrante que o narrador não divide o conteúdo das cartas com o leitor, também condenado a suportar a ausência de diálogos e esclarecimentos.

A presença recorrente do jornal e do tricô revelam uma dimensão importante do texto: o embate velado entre palavras e agulhas, isto é, entre uma esfera dominada canonicamente por homens e outra eminentemente feminina. $\mathrm{O}$ trabalho de tricô evidencia, ainda, a esfera da produção artística, aqui apequenada em artesanato. Segundo a crítica Carla Cristina Garcia, o artesanato foi considerado ao longo de décadas uma atividade secundária, uma vez que a utilidade dos artefatos artesanais diminui o seu valor artístico:

\begin{abstract}
A polêmica estava servida: quais são as chaves para discernir entre arte a e artesanato $e$ as razões? As artistas tinham consciência de que o conhecimento tradicional das mulheres $e$ as artes populares compartilhavam uma condição semelhante; mesmo que presentes na vida diária, em geral ninguém percebe sua presença. São quase tão invisíveis quanto insignificantes. Há um duplo processo de marginalização que é preciso reverter. Muitas das atividades criativas das mulheres ficaram ocultas por trás dos trabalhos da casa. Rever os conceitos sobre arte popular, trabalhos domésticos, arte e artesanato, permite tirar do anonimato a milhares de mulheres que no passado - e no presente- trabalharam em ramos das artes que foram entendidos como inferiores sem mais critério do que o preconceito social, racial ou de gênero. (Garcia, 2016, pp. 06 e 07)
\end{abstract}

A alternância de palavra e tecido segue um fluxo que é quase um tango na malha narrativa: tensão, encontro, afastamento vão marcando o aparecimento da toalhinha e do jornal:

- Que vai fazer?

- Queimar.

Não, ele acode. Enfia o bilhete no envelope, guarda no bolso. Ergue a toalhinha caída no chão e prossegue a leitura do jornal.

A dona recolhe a cestinha, o fio e as agulhas. 
- Não ligue, minha velha. Uma carta jogada em todas as portas.

O canto das sereias chega ao coração dos velhos? Esquece o papel no bolso, outra semana passa. No sábado, antes de abrir a porta, sabe da carta à espera. A mulher pisa-a, fingindo que não vê. Ele a apanha e mete no bolso. (Trevisan, 2009, p. 217)

Por outro lado, a menção das sereias aproxima ainda mais o conto da narrativa homérica. Na cultura grega as sirenas eram mulheres-pássaro ${ }^{76}$ terriveis, que levavam os homens à loucura com o seu canto sedutor e depois devoravam seus corpos e ossos: "As sereias pertencem ao mesmo tempo ao mundo subterrâneo dos infernos, ao mundo celeste da música e ao universo marinho dos navegadores." (Brunuel, 2005, p. 829). Ulisses só escapa do embate com as sirenas por mandar seus homens taparem os ouvidos com cera de abelha e ele mesmo - 0 homem que tudo deseja saber - pede para ser amarrado ao leme do barco, a fim de poder ouvir o canto sem se atirar ao mar.

Ao indagar se o canto das sereias ainda chega ao coração dos velhos, a personagem pergunta-se se ainda há desejo, sedução e volúpia na velhice. $\mathrm{O}$ tabu do sexo e da paixão na velhice, portanto, comparece aqui. No entanto, o que o conto mostra é a negação desse tabu: o protagonista mais do que nunca deseja controlar o corpo da esposa, de modo a assumir a possibilidade de uma sexualidade plena na velhice. Sobre o tabu da sexualidade, afirmam Alves \& Rozendo (2015):

\begin{abstract}
A velhice na cultura ocidental ainda hoje é sinônimo de incapacidade, de decadência, de perdas biológicas, e sociais (Groisman, 2002). Enfim, um estado de declínio, de decrepitude física e mental, tornando os idosos despojados no campo econômico, social e também xual. Conforme assinalam Gradim, Souza e Lobo (2007), envelhecer não está atrelado a enfraquecer, ficar triste, ou ser assexuado. Entretanto, na civilização hodierna, diversos mitos e atitudes sociais são atribuídos às pessoas com idade avançada, principalmente os relacionados à sexualidade, dificultando a discussão sobre a sexualidade nas idades mais avançadas. (Alves \& Rozendo, 2015, p. 02)
\end{abstract}

Por outro lado, Penélope e Ulisses na épica homérica só se reencontram já de cabelos brancos e a aurora demora para irromper a fim de que o casal possa aproveitar a intimidade da alcova. Nesse sentido, o tempo não teve poder sobre o casal homérico, enfatizando a força de seu amor e também sublinhando o esgarçamento do amor do casal do conto, posto que o par realiza o movimento inverso: depois de décadas de convívio o velho cria uma odisseia imaginária em que deve enfrentar périplos e inimigos enquanto a velha tece seu adultério.

${ }^{76}$ Cf BRUNUEL, Pierre. Dicionário de Mitos Literários, 2005, p. 829 
Contudo, a atmosfera de animosidade é, às vezes, rompida por uma emanação de ternura:

Ombros curvados, contando a mesma linha, ela pergunta:

- Não vai ler?

Por cima do jornal admira a cabeça querida, sem cabelo branco, os olhos que, apesar dos anos, azuis como no primeiro dia.

- Já sei o que diz.

- Por que não queima? (Trevisan, 2009, p. 217)

Apesar da desconfiança, o velho consegue enxergar na companheira, nesse momento pontual, a mesma mulher com quem se casara décadas antes. A passagem do tempo parece ter menos efeito sobre a esposa, que permanece com os mesmo olhos azuis e cabelos jovens. Tal diferença pode ser um dos fatores que acentuam os ciúmes nutridos pelo velho. Contudo, nessa pausa do embate, a expressão "cabeça querida" diz muito do carinho do velho, que lança um olhar terno à parceira e que em breve terá que encarar a solidão de não ter uma companhia e o silêncio deixado pela ausência do bater de agulhas.

É um jogo, e exibe a carta: nenhum endereço. Abre-a, duas palavras recortadas. Sopra o envelope, sacode-o sobre o tapete, mais nada. Coleciona-a com a outra e, ao dobrar o jornal, a amiga desmancha um ponto errado na toalhinha.

Acorda no meio da noite, salta da cama, vai olhar à janela. Afasta a cortina, ali na sombra um vulto de homem. Mão crispada, até o outro ir-se embora. (Trevisan, 2009, p. 218)

O vulto do misterioso amante que aparece da janela parece muito mais um evento da ordem do delírio do que do real. Dalton não fortuitamente faz as palavras sopradas no envelope plainarem lentamente sobre o tapete, em uma imagem que reforça o ballet da palavra e da tessitura. A sincronia do jornal e da toalhinha também é reiterada nesse excerto, preparando o leitor para o paralelo das tragédias tecidas em palavras no jornal com a tragédia familiar que a velha urde ponto a ponto em sua toalhinha. Tal urdidura minuciosa e lenta da toalhinha de mesa pontua o silêncio do narrado e faz o narrador evocar a história de Penélope:

(...) voltando as folhas, surpreende o rosto debruçado sobre as agulhas. Toalhinha difícil, trabalhada havia meses. Recorda a legenda de Penélope, que desfaz à noite, à luz do archote, as linhas acabadas no dia e assim ganha tempo de seus pretendentes. Cala-se no meio da história: ao marido ausente enganou Penélope? Para quem trançava a mortalha? Continuou a lida nas agulhas após o regresso de Ulisses? (Trevisan, 2009, p. 218) 
Ao estabelecer o paralelo com o mito grego, a personagem questiona a configuração canônica da fidelidade de Penélope. Na visão do velho, a heroína homérica ao ser capaz de usar a astúcia para produzir o ardil do tear, poderia muito bem também ter enganado a seu marido Ulisses. O senhor capta os matizes da ambivalência de Penélope e os usa como prova contra a própria esposa.

Sabe-se que a mortalha tecida na Odisseia era para o pai de Ulisses, Laerte, de modo que a pergunta "Para quem trançava a mortalha?" serve não só como questionamento da matéria mítica, mas também como questionamento acerca da toalhinha, que posteriormente o leitor saberá que é simbolicamente a mortalha da velha. A última questão "Continuou a lida nas agulhas após o regresso de Ulisses?" coloca em xeque a postura da velha, já que Penélope tecia na ausência do marido e a velha tricota na presença do marido. O velho, assim, acredita que a sua esposa o quer manter a distância para manter-se fiel a um terceiro ausente, bem como Penélope afastava os pretendentes por lealdade a Ulisses. Em suma, o narrador coloca em questão a fidelidade da heroína homérica e, consequentemente, a da própria esposa.

O texto ainda invoca a presença do mito de Penélope ao citar textualmente os pretendentes. Na Odisseia, os filhos da nobreza de Ítaca desejam ardentemente a mão da rainha para ocupar o lugar social de Ulisses. Para tanto, violam o espaço da casa do herói; de modo análogo o vulto parece violar a casa do velho.

Em contrapartida, há cenas de acessos de ciúme que beiram a patologia e que geram uma espécie de estranheza, já que o senso comum postula que a velhice é o momento de declínio da sexualidade e da sensualidade:

Desde a rua vigia os passos da mulher dentro de casa. Ela vai encontra-lo no portão - no olho o reflexo da gravata do outro. Ah, erguerIhe o cabelo da nuca, se não tem sinais de dente... Na ausência dela, abre o guarda-roupa enterra a cabeça nos vestidos. Atrás da cortina espiona os tipos que cruzam a calçada. Conhece o leiteiro e o padeiro, moços, de sorrisos falsos.

Reconstitui os gestos da amiga: pós nos móveis, a terra nos vasos de violetas úmida ou seca... Pela toalhinha marca o tempo. Sabe quantas linhas a mulher tricoteia e quando, errando o ponto, deve desmanchá-lo, antes mesmo de contar na ponta da agulha. (Trevisan, 2009, p. 219)

O ciúme do velho torna-se gradativamente obsessão, ele passa a espreitar e a seguir a esposa, conhecendo seus rastros nas atividades domésticas e têxteis, decorando o ritmo de suas laçadas e regulamentando seu corpo. Como Penélope, ele passa a medir o tempo por meio da toalhinha, não para postular a fidelidade, 
mas para impor a lealdade à esposa graças à vigilância constante. A paranoia chega a um nível tão grave que ele compra um revólver:

Sem prova contra ela, nunca revelou o fim de Penélope. Enquanto lê, observa o rosto na sombra do abajur. Ao ouvir passos, esgueirando-se na ponta dos pés, espreita à janela: a cortina machucada pela mão raivosa. Afinal compra um revólver. (Trevisan, 2009, p. 219)

O revólver indica o desequilíbrio do velho, que tomado pelo ciúme começa a ter atitudes irracionais e persecutórias. Ele passa a esperar o amante na varanda, certo de que pegaria a esposa em flagrante. Decora os cheiros e texturas a fim de controlar o ambiente que circunda a mulher. A arma é signo maior de seu desvario: se não é possível encarcerar o corpo amado, a única alternativa é eliminá-lo a fim de interromper o ciclo de suspeitas:

Aguarda-o na varanda. Se não a conhecesse, ele passa diante da casa. Na volta, sente os cheiros no ar, corre o dedo sobre os móveis, apalpa a terra das violetas - sabe onde está a mulher.

De madrugada acorda, o travesseiro ainda quente da outra cabeça. Sob a porta, uma luz na sala. Faz o seu tricô, sempre a toalhinha. É Penélope a desfazer na noite o trabalho de mais um dia?

Erguendo os olhos, a mulher dá com o revólver. Batem as agulhas, sem fio. Jamais soube por que a poupou. Assim que se deitam, ele cai em sono profundo.

Essa cena marca o ímpeto assassino do velho, ao deparar com a ausência da mulher em sua cama, saca o revólver, certo de que capturaria o momento do adultério. Ela, entretanto, tricota na sala. A pergunta "Penélope a desfazer na noite o trabalho de mais um dia?", para além de evocar textualmente o mito homérico mais uma vez, faz com que o leitor se inquira qual malha esta Penélope apequenada e citadina está desfazendo: o velho pensa que são as tramas da fidelidade e do casamento que a esposa descompõe, já a voz narrativa nos revela que os fios que se desatam são os do amor - tornado medo - e de sua própria vida.

Acha sempre o cabelo, nunca mais a mulher decifrou as duas palavras. Ou - ele se pergunta, com nova ruga na testa - descobriu a arte de ler sem desmanchar a teia? (Trevisan, 2009, p. 221)

No fragmento, há outra menção explícita à íntima relação da tecelagem e da narrativa, ao aproximar a leitura e a teia. Por outro lado, é o velho quem urde a armadilha desta vez. Ele que cria o ardil do fio de cabelo a fim de vigiar a esposa, de modo que se faz a aranha do enredo, montando sua teia para capturar a esposa em seu suposto deslize. 
Esse deslocamento é curioso, uma vez que a aranha é o animal cujo comportamento sexual consiste na fêmea devorar o macho após a cópula. O marido parece enxergar a mulher como aranha e para se defender dela usa suas próprias armas, aprendendo a manipular ardis e se assegurando com um revólver para impedir que ela o devore. No entanto, o desfecho revela o contrário, a esposa não tinha interesse em assassinar o marido, como aranha vingativa; a velha, ao concluir seu trabalho de agulhas, comete suicídio, manchando com sangue a manta de Penélope:

Uma tarde abre a porta e aspira o ar. Desliza o dedo sobre os móveis: pó. Tateia a terra dos vasos: seca.

Direto ao quarto de janelas fechadas e acende a luz. A velha ali na cama, revólver na mão, vestido branco ensanguentado. Deixa-a de olho aberto. (Trevisan, 2009, p. 221)

Tal passagem permite afirmar que essa Penélope prosaica também atua como uma Moira do cotidiano, pois opta por cortar o fio de sua vida. Há, portanto, uma duplicidade na personagem: ela é não só Penélope que tece a própria mortalha, mas também a moira que aniquila o próprio destino e a aranha que urde uma tragédia, castigando o marido com sua ausência e seu silêncio. "Penélope" se faz o texto mais violento do corpus, pois o ciúme aparece entremeado nas malhas textuais e estrutura uma tragédia burguesa:

A polícia o manda em paz, longe de casa à hora do suicídio. Quando sai o enterro, comentam os vizinhos a sua dor profunda, não chora. (...) Entra na sala, vê a toalhinha na mesa - a toalhinha de tricô. Penélope havia concluído a obra, era a própria mortalha que tecia - o marido em casa. (Trevisan, 2009, p. 222)

Ao retornar para o espaço de segurança da casa, encontra a toalhinha sobre a mesa. Durante o enterro da esposa, o velho não demonstra estar abalado emocionalmente, contudo no espaço privado ele é obrigado a lidar com a ausência da mulher. Ela se foi, mas tudo aquilo que era seu permaneceu, evocando lembranças a todo instante:

Acende o abajur de franja verde. Sobre a poltrona, as agulhas cruzadas na cestinha. É sábado, sim. Pessoa alguma lhe pode fazer mal. A mulher pagou pelo crime. Ou - de repente o alarido no peito - acaso inocente? A carta jogada sob outras portas... Por engano na sua.

Só após a morte da esposa ele é capaz de avaliar a sua possível inocência. Tenta, então, retomar a rotina, aos sábados eles passeavam juntos. Era também 
aos sábados que as cartas chegavam. No retorno do passeio a ironia e o desejo de vingança convertem-se em arrependimento: a carta foi novamente entregue; prova cabal da inocência da velha. Lutando contra a verdade, incapaz de suportar o silêncio deixado pela ausência das agulhas, ele invoca a palavra em sua dimensão de oralidade a fim de aplacar a culpa:

Sai de casa, como todo sábado. O braço dobrado, hábito de dá-lo à amiga em tantos anos. Diante da vitrina com vestidos, alguns brancos, o peso da mão dela. Sorri desdenhoso da sua vaidade, ainda morta...

Os dois degraus da varanda - "Fui justo", repete, "fui justo" —, com mão firme gira a chave. Abre a porta, pisa na carta e, sentando-se na poltrona, lê o jornal em voz alta para não ouvir os gritos do silêncio.

"Penélope" configura-se, portanto, o texto mais trágico do corpus e o mais carregado de matizes de angústia e de dissolução amorosa e humana. Enquanto os demais apontavam para a esperança ora no amor ora na autonomia, em "Penélope" a única saída possível para a mulher é o suicídio. Uma vez que não resta voz a ser assumida por ela nessa casa suburbana, suas libertação e afirmação de autonomia estão em cortar os fios que a ligam a vida e a um marido obsessivo.

Traços da poética do mito comparecem na narrativa de Dalton Trevisan, colocando-a na teia de relações com os outros textos do corpus. Podemos destacar, em primeiro lugar, a repetição, fortemente marcada pelos gestos repetitivos ligados ao tricô e ao jornal e, sobretudo, reiterada na construção dos ciúmes excessivos do velho. O desejo de controle por parte do protagonista o leva a pensamentos e atitudes circulares, como a de investigar os vasos e móveis para mensurar a localização da mulher. As chegada contínua das cartas a cada sábado e a rotina do casal, mantida até mesmo na viuvez, também enfatizam esse traço mítico na formulação do conto.

A metonímia - um dos traços estruturais no mito - sobrepõe-se à metáfora nesse conto, numa tentativa de impessoalizar as personagens, trocando-as pelos objetos que as cercam em consonância com a poética da crueza de Dalton Trevisan. As metáforas e analogias comparecem, particularmente, nas relações com a tecelagem e com o mito de Penélope. Já o tempo, apresenta marcas de indeterminação e de reiteração, quebradas apenas pela ancoragem dos sábados, dia fundamental para o andamento do enredo.

Essa narrativa, no entanto, distancia-se da poética do mito em dois aspectos: a oralidade pouco comparece, já que o narrador filtra as falas das personagens e a 
formulação assertiva também não é empregada, já que o conto se estrutura pela desconfiança e, portanto, encontramos muito mais formulações de questionamento.

É possível afirmar que a tensão entre arcaico e moderno aparece na narrativa refletindo a hipocrisia da burguesia urbana e o paradoxo entre os avanços do asfalto e o congelamento de valores conservadores. Por um lado, os valores veiculados são de formulação moderna, uma vez que a velha prefere assumir a autonomia e romper os elos com a vida a continuar a enfrentar as violações e a agressividade do marido; por outro lado, são valores patriarcais que sustentam o narrado, pois não há para a personagem, habituada à imobilidade e ao silêncio de seus papéis de mulher e idosa a alternativa de separar-se e seguir com sua existência longe de seu algoz. No choque do arcaico com o moderno, Dalton questiona a pretensa modernização das áreas urbanas, que mantém em seus subúrbios o mesmo funcionamento de vigilância das pequenas aldeias.

\subsection{Tessitura e Memória}

\section{Mulher-bordadora}

Secretamente teces as lágrimas com que bordas a solidão laqueada em que adormeces (Maria Teresa Horta)

Já em "Ponto de Crochê" (2009), o tema da tecelagem comparece tanto na construção do enredo quanto na fatura do conto. O próprio título já suscita relações pertinentes com a as artes têxteis. A narrativa intercala memórias, pensamentos e sentimentos da protagonista com os movimentos próprios do crochê: laçadas, viradas de agulha, ponto feito e desfeito.

Esse é o segundo conto da obra Novelas nada exemplares que abarca o tema da tecelagem e que irá colocar em cena o paralelo entre narrar e tecer:

Em Novelas nada exemplares, dois contos mostram-se extremamente significativos do ponto de vista metalinguístico. No primeiro deles "Ponto de crochê"(p.103-5), a esposa aguarda a chegada do marido bêbado, enquanto realiza um trabalho em crochê. Há aí todo um jogo de recuperação do passado, mesclado a impressões do presente, pois, ao mesmo tempo que a agulha tece, engata também o fio da memória da personagem. A trama ficcional apresenta-se, então, fundida à trama tecida no trabalho de crochê que os pontos de recalque do passado são marcados pela perda do ponto criado pelo enlace entre agulha e linha. Como 
Penélope a mulher desmancha a carreira e recomeça, num constante refazer, que só será interrompido ao ouvir os passos trôpegos do marido. Como Aracne, ela faz da linha o fio de uma teia narrativa, envolvendo e enlaçando o homem com o enredo bem urdido. (Comitti, 1996, p. 84).

Desse modo, a narrativa espelha a estrutura da trama, composta pelo entrecruzamento de fios e de espaços vazios, que evocam as lacunas da memória, sempre falha em sua reconstituição do vivido. Trata-se de um texto que rompe com a linearidade, arrematando tessitura e memória, passado e presente, dito e nãodito. Por sua configuração em espiral o conto exige uma leitura atenta, a fim de que se possam identificar os fios e vozes que se misturam em sua construção:

No momento da leitura, se faz necessário uma inter-relação com suas outras leituras, com suas experiências de vida, a fim de "construir" o entendimento do texto, ou seja, o leitor deve refazer o percurso de Teseu, seguindo o fio de Ariadne, a fim de desvendar esse labirinto e retornar à luz: ao entendimento. (Silva, 2013, p. 01)

A narrativa já se inicia a partir de uma lacuna; as reticências que inauguram a primeira linha do conto revelam que estamos acompanhando um movimento de pensamento que continua e a cujo início não teremos acesso:

...Ponto de uma laçada, meio ponto, sob o vidrilho azul do abajur, pontas de agulha que revolvem a memória, menina de tranças no espelho dourado da sala, oh! Banguela, oh! Cirandinha, meu anel era de vidro, você é mulher imprestável; por favor, mãe, o grande leão do circo. De quem o retrato Gabriel, Essa fulana quem é? (Trevisan, 2009, p. 135)

A montagem do enredo é realizada a partir da lacuna numa tentativa de paráfrase da memória, que se apresenta sempre de maneira parcial. Como a narração segue o fio mnemônico, temos uma visão fragmentária, filtrada pelas impressões do sujeito. Segundo Freud, "Algumas das imagens mnêmicas certamente são falsificadas, incompletas ou deslocadas no tempo e no espaço." (Freud, 1901, p.62).

Por isso o excerto intercala eventos muito remotos - como a narradora ainda menina de tranças e banguela diante do espelho da sala - com acontecimentos recentes em que se recorda de uma frase agressiva que escutou do marido: "você é mulher imprestável". Há ainda evocação à cantiga infantil "Ciranda, cirandinha" que irá ecoar ao longo do texto, o anel de vidro nessa cantiga popular representa o fim do amor: "o anel que tu me deste era vidro e se quebrou, o amor que tu me tinhas era pouco e se acabou." Outra voz que pode ser distinguida é a do filho pequeno que chama a narradora pelo vocativo "mãe". 
A crítica Josefa Zenil (2013) observa que, ainda que o material narrativo seja apresentado de maneira fragmentada é possível recuperar alguns papéis: a esposa é a mulher que crocheta, o marido chama-se Gabriel e se envolveu com a mulher do retrato, há ainda a presença do filho do casal, Joãozinho. A autora afirma que o casal possui dois filhos, uma criança e um adolescente, contudo em nossa análise pensamos que esse deslizamento entre o filho criança e o filho adolescente é um dos efeitos mnemônicos. A protagonista, revela entre um ponto e outro os dramas da sua existência: a relação conturbada com o marido, o cuidado com as crianças e o retrato de uma mulher fatal que instaurou o desvio na trama.

A ponta da agulha, durante o trabalho artesanal da narradora instiga, pari passu, a memória, numa reconstituição gradual e, portanto, cronológica, de fatos que transcorreram na vida da mulher, quais sejam, a infância e sua liberdade de brincar; a juventude, já com a presença do marido a criticá-la; a maternidade e suas implicações de proteção ao filho e, finalmente, a desconfiança acerca da fidelidade do marido, praticamente constatada na pergunta retórica. Toda essa evocação vem aos poucos visitar os pensamentos da narradora, em movimento simétrico aos pontos que ela entremeia no trabalho com o crochê. Essa mistura de sons e imagens, evocados pelo ziguezaguear da agulha no tecido, remete ao funcionamento da memória:

O recordar, nos adultos, sabidamente utiliza diversos materiais psíquicos. Alguns recordam em imagens visuais; suas lembranças têm um caráter visual. Outras mal conseguem reproduzir na lembrança os mais vagos contornos [visuais] do que foi vivenciado; (Freud, 1901, p.62)

A lembrança, portanto, aparece no conto em um fluxo que parafraseia o movimento da agulha de crochê; cada imagem é intercalada com um ponto, de modo que as laçadas arrematam memória e tessitura:

Três trancinhas, meio ponto, ponto de duas laçadas, boca do filho
mordendo-lhe o seio. Perdão, mãe, não faço mais, o leão de boca
escancarada no picadeiro; ervilhas para o almoço, quanto é a dúzia de
ovos? vinte anos de casados, vamos celebrar, Gabriel? Que a Anita brigou
com o noivo, não? pois brigou. Meu filho, respeite seu pai, disse Jesus,
ponto meio ponto. Meu pai é um cretino. Ora, um dia igual aos outros...
Bigode de homem na água trêmula e, Jesus Maria José, se tivesse fugido
como a Alzira? Desmanchar o ponto, errou. (Trevisan, 2009, p. 135)

Nesse momento do texto, a memória volta-se para elementos relativos à boca: a amamentação, a fala, o almoço, a pergunta, a briga constituem elementos que remetem ao órgão. Podemos afirmar que o texto traça um percuso de 
encadeamento que perpassa todos os sentidos, mobilizando e condensando diversos materiais psíquicos em sua formulação.

Os assuntos de tais lembranças ora são extremamente prosaicos, versando sobre o cotidiano dos filhos e os afazeres domésticos - amamentar o filho, preparar o almoço, realizar as compras para a casa - ora abordam situações importantes na esfera afetiva - o casamento de vinte anos que a protagonista ainda deseja celebrar mesclado ao desejo de liberdade, de ser capaz de fugir como Alzira o fez e cortar os laços que a prendem a tal rotina banal: "Ora um dia igual aos outros...". Na verdade essa assertiva pode ser tanto uma afirmação da mulher que crocheta quanto a resposta do marido ao convite de celebração do casamento, contudo as duas leituras refletem a vida monótona levada por essa mulher.

O gato comeu, disse, rindo-se ao vê-lo em cueca xadrez. Mãe, quem é a mulher do retrato? Essa fulana levou seu pai à falência. Meu pai é um cretino. Gabriel chorando, a cabeça nas mãos.

Homem fraco, ponto de duas laçadas. Uma vez, numa rua, numa tarde, uma vez, numa rua, numa tarde, um homem. Dedos alheios dirigindo a agulha, mãe, olha lá o leão. (Trevisan, 2009, p. 136)

Aqui, podemos notar mais uma vez a referência a uma mulher alheia ao núcleo familiar. A esposa enxerga essa mulher como a causa da decadência do pai e como quem tira a família de sua linearidade. Apenas a voz do filho culpabiliza Gabriel por sua atitude adúltera, indício de ruptura com a estrutura patriarcal. A crítica já observara que a expressão "ponto de duas laçadas" nessa passagem do texto refere-se às duas mulheres com quem Gabriel se envolve: a esposa e a amante. Contudo, a voz da narração também espelha o ponto: ao afirmar a dupla repetição do movimento também repete a frase seguinte, acompanhando o movimento do crochê: "uma vez, numa rua, numa tarde; uma ver, numa rua, numa tarde". Já os dedos que movimentam a agulha remetem ao dedo do filho pequeno apontando o leão

Gosta deste quimono? Não elogiou o quimono de seda, a mão sem ruído cruzando o fio, irresistível fim de tudo, duas solteironas à janela - o sol na parede amarela. Menina de tranças diante do espelho, o chinelo gasto a seus pés, ao lado de cestinha de costura: uma, duas, três meias a cerzir. Amanhã quinta-feira, macarrão para o almoço - mais pó sobre os móveis. (Trevisan, 2009, p. 136)

A presença do quimono de seda intensifica a presença tátil do tecido na narrativa; o toque aveludado da seda remete à mão que cruza o fio, que 
imediatamente evoca uma cena do passado em que o sol quente pode ,r sentido na pele. Esse momento, portanto, estrutura-se pelas lembranças ligadas ao tato. Ainda nessa linha de leitura, o chinelo gasto incomoda a cútis; ao olhar para o chão a mulher vê a cesta de costura e os trabalhos de reparo que ainda deve realizar. Os mesmos fios da agulha a remetem aos fios de massa do macarrão que deve preparar na manhã seguinte. Dessa maneira, uma lembrança vai puxando o fio da outra em uma tentativa bem-sucedida de mimetizar o funcionamento mnêmico.

Um ponto, um pensamento, e outro, depois outro, o silêncio da madrugada. Gabriel bêbado que chegou da farra: Por tua causa colombina, passei um triste carnaval... sonhou com dona Matilde, dedo gelado de morta, a face perdida na sombra: meu filho, quer arroz? meu filho, quer um copo de leite? Meu filho não quer. (Trevisan, 2009, p. 137)

Na passagem, a protagonista rememora a vida boêmia de Gabriel. A cantiga alude ao carnaval, momento do ano em que as personagens da Comédia dell Arte italiana ainda são celebradas. A presença de tais referências culturais ainda contribui para a presença do adultério no enredo, uma vez que a história de Colombina, Arlequim e Pierrot é também a de um triângulo amoroso. Em seguida, a mulher, incomodada com o comportamento do marido, relembra de um sonho, protagonizado aparentemente pela sogra - dona Matilde - que poderia fazer Gabriel pensar acerca do vício.

\footnotetext{
E disse, o negro véu molhado na boca: Do que eu mais gosto é um copo de cerveja. Gabriel deixar o vício? Se contasse o sonho... Não, rir-se-iam, pai e fiho, da pobre Matilde. O velho chapéu no cabide, anúncio de sua volta. Dedos velozes sob o vidrilho azul: sou feia? dona sedutora? Por tua causa, colombina. (Trevisan, 2009, p. 137)
}

Nesse momento, o alcoolismo de Gabriel é evidenciado, por meio da metonímia da cerveja. Os fragmentos nos permitem reconstruir uma rotina boêmia e adúltera de Gabriel, enquanto a sua esposa permanece ocupada com os afazeres do lar, o cuidado com os filhos e a costura, recolocando-a em uma posição de submissão patriarcal. Ainda que essa mulher seja uma das mais apassivadas do corpus há nela uma resitência psíquica para elaborar a própria memória.

A sua ação parece ser a de uma Ariadne, que ao desenrolar o novelo da lembrança salvará a si mesma do labirinto sufocante de sia vida cotidiana. Ao olharse como colombina no espelho e se vestir de vermelho, adornando-se, ela revela um pequeno ímpeto, quase microscópico, de abandonar a rotina, contudo recua ao escutar os passos trôpegos de Gabriel no corredor. Contudo, ainda que haja uma 
hesitação, a tendência de um sujeito voltado para a sua subjetividade e para a sua rememoração é que ele consiga romper com a repetição e reelaborar sua experiência.

Vestido vermelho de veludo, anéis nos dez dedos, uma pérola na orelha, mulher chorando na tarde, ponto de duas laçadas - o sorriso desdenhoso na lágrima. Guardou o novelo, a agulha, a toalha na cestinha. Ergueu o rosto para o corredor iluminado, os passos agora mais perto. (Trevisan, 2009, p. $137,138)$

Dessa maneira, a personagem parece tecer, materialmente, um trabalho de crochê e, subjetivamente, um discurso reflexivo e memorialista que busca elaborar as tensões de sua existência. Por isso, é possível relacionar a personagem a uma moira apequenada pela banalidade urbana, visando compreender os fios do seu destino para poder retomá-lo e continuar a urdi-lo. Há ainda uma espécie de movimento terapêutico na ligação entre linhas e signos que começa a elaborar um significado para as experiências psíquicas da protagonista.

Em "Ponto de Crochê" (2009), a poética do mito comparece com força na atmosfera de indeterminação temporal regida pela lembrança. Além disso, a repetição também será traço constitutivo tanto do universo mítico quanto da memória. Além disso, a metonímia é mais intensa do que a metáfora nesse conto, reforçando a lógica do fragmento que permeia a obra de Dalton Trevisan. Os demais traços do discurso mítico - oralidade e formulação assertiva - assim como na outra narrativa de Trevisan analisada por nós, não ganham força já que a memória é permeada por ambivalências e constitui um fluxo subjetivo não exteriorizado pela oralidade.

As relações entre modernidade e mundo arcaico comparecem no choque do universo urbano, que pressupõe progresso com os valores patriarcais que delegam todas as funções domésticas e de estruturação do lar à protagonista e endossam a vida boêmia e irresponsável de Gabriel. 


\section{3 Últimos elos da teia}

\section{Com que vida?}

Que silêncio

foi bordado

fio a fio - na secular solidão

das horas repetidas?

Em que pano

brando

desenharam teus dedos a partida

o fundo penumbroso dos teus dias?

Com que agulha puxada à altura do peito, mulher?

Com que vida?

(Maria Teresa Horta)

Nessa última etapa do trabalho, é necessário fecharmos a nossa teia de relações introduzindo as narrativas de Trevisan. O conto "Penélope" pode ser relacionado a "Desenredo" devido a tópica do adultério, contudo, enquanto neste temos um adultério efetivo que é reelaborado em pureza pelas habilidades textuais de Jó Joaquim, naquele acompanhamos o movimento inverso. É o velho que fantasia o adultério e que vai construindo com pistas cotidianas o enredo da traição, transformando a esposa antes fiel em adúltera. É curioso que o tifo seja mencionado nas duas narrativas, em "Desenredo", aparece como uma das prováveis causa mortis do primeiro marido de Livíria e, em "Penélope", como a razão do óbito do primo da esposa, com o qual ela havia tido um romance.

Não só a postura dos dois homens é completamente divergente, mas também a das protagonistas: Livíria ao trair o amante e posteriormente esposo reafirma sua liberdade de escolha, não se dispõe a prender-se nas amarras da culpa e do sofrimento, já a velha, confinada em uma rede de suspeitas, não invoca a própria voz em nenhum momento a fim de se defender das acusações do esposo. Para uma mulher-palavra e outra mulher-silêncio, desfechos totalmente diferentes: a antipenélope Livíria encontra a felicidade e vive o melhor de sua útil vida ao lado do homem que reconstruiu a sua imagem; a Penélope idosa e apequenada, fragilizada 
pelas acusações do marido, corta o fio da vida, lançando o esposo à punição eterna de sabê-la inocente.

A presença têxtil é mais explícita em "Penélope", embora a presença da criação por meio da palavra seja mais sutil. No entanto, é a palavra escrita que mobiliza o enredo, posto que são as cartas adúlteras que colocam em movimento o conflito e o desfecho da obra. Nesse sentido, podemos aproximar "Penélope" e "A vela ao diabo", cuja trama também é mobilizada pela troca de cartas. Contudo, no conto de Rosa o remetente e o destinatário das cartas são de conhecimento do leitor - Zidica e Teresinho- que trocam votos de amor, enquanto no conto de Dalton é o desconhecimento do remetente que gera boa parte da trama de suspeitas.

Em "A vela ao diabo" também há uma personagem declaradamente pertencente à linhagem das tecelãs fatais, Dlena, enquanto em "Penélope" é apenas o delírio do velho que o faz enxergar sua esposa - tecelã sensata - como tecelã fatal. Outra diferença sensível se constata na interferência de Dlena nas cartas que gera a ruptura amorosa, enquanto em Trevisan a mulher é julgada por cartas que não escreve e nem recebe. $O$ ato de tricotar da velha pode ser igualmente comparado à confecção do enxoval de Zidica, isto é, é como se seu papel fosse simétrico ao de Zidica, mas as lentes do ciúme fizessem com que o marido a visse como Dlena.

"Penélope" ainda estabelece diálogos com "Colheita", de Nélida Piñon, em diversos aspectos. Primeiramente, em ambos os contos, encontramos personagens que não são nomeadas e, portanto, remetem a uma generalização. O espaço também se assemelha, ainda que no primeiro conto encontremos o espaço urbano e no segundo o rural, as duas narrativas são bastante centradas no ambiente doméstico, segundo Souza \& Cavalcante (2012, p. 14 e 15) essa relação com a casa se dá não só porque as narrativas ocorrem dentro da casa dos casais, mas também pela relação das mulheres com esse lugar em que cumprem suas funções de donas de casa e esposas.

Segundo a análise de Souza \& Cavalcante (2012, p. 11), outro elo que aproxima "Colheita" e "Penélope" é a menção ao suicídio, que no conto de Trevisan se efetiva e na narrativa de Piñon é apenas apresentado como um pensamento da mulher ao não mais suportar a ausência do marido: "eu vivo só, não sei se a guerra tragou você, não sei sequer se devo comemorar a sua morte com o sacrifício da minha vida." (Piñon, 1997, p. 99), mas tal possibilidade é logo refutada, pois "a morte 
era uma vertente exagerada."(Piñon, 1997, p. 99 ).

O manejo da terra também é encenado de maneira consistente nos dois contos, em Nélida, a mulher e o homem partilham o estatuto de rei e rainha da terra: "Dominava as paisagens no modo ativo de agrupar frutos e os comia nas sendas minúsculas das montanhas, e ainda pela alegria com que distribuía sementes. A cada terra a sua verdade de semente, ele se dizia sorrindo." (Piñon, 1997, p. 97). Já em "Penélope", o casal de velhos também partilha a lida com a terra ao cuidar da horta e do canteiro de malvas, contudo nenhum dos dois amores se demonstra plenamente fecundo depois de um tempo: Em "Colheita" o marido parte em busca de novas aventuras, em "Penélope" o marido fantasia uma traição e passa a regar os seus dias com agressividade.

Outro traço que pode aproximar as narrativas é a centralidade das atividades domésticas na configuração subjetiva das mulheres. As duas protagonistas cuidam da casa, cozinham, varrem e realizam atividades relativas à tecelagem; porém, a mulher de "Colheita" usa esses recursos em um processo de autoconhecimento e emancipação, já a velha do conto de Trevisan passa a sofrer perseguições por parte de seu marido; até mesmo nessas ações do cotidiano, ele a vigia por meio do pó nos móveis e da terra seca dos vasos, revelando que não há espaço para a subjetividade dessa mulher.

Nesse sentido, a diferença mais sensível entre as protagonistas é o fato de a mulher de Nélida elaborar a dor da ausência em discurso e, por meio da palavra, alcançar sua autonomia, enquanto a senhora de Dalton confina-se em seu silêncio e enxerga na morte a única possibilidade de emancipação.

"A Moça Tecelã", de Marina Colasanti, dialoga igualmente com "Penélope", uma vez que as duas protagonistas, além de realizar um trabalho têxtil explícito, definem o próprio destino e o de seus cônjuges. A moça de Marina, em seu universo feérico, opta por destecer o marido tirano, agindo como a Moira Láquesis e interferindo no fio do destino. Já a velha de Dalton, opta por encarnar a Moira Átropos, cortando o fio de sua vida e redimensionando a trajetória do marido, uma vez que o obriga a rememorar a culpa de ter desencadeado a morte da amada que não cometera adultério.

A outra narrativa de Dalton Trevisan, "Ponto de Crochê", pode ser relacionada a "Desenredo" primeiramente devido à temática da traição, embora seus papéis se invertam, pois em "Ponto de Crochê" é o homem o adúltero. Em segundo 
lugar, os dois contos recuperam a tradição: em Rosa há um diálogo com a Odisseia e com as matrizes bíblicas, em Trevisan recuperam-se as personagens da Comédia Dell Arte e as cantigas populares infantis.

A reelaboração também comparece em ambos os textos, só que em "Desenredo" a reelaboração literária sobrepõe-se a reelaboração mnêmica - já que Jó reescreve Livíria para adequá-la aos arquétipos, embora também opere com a memória popular para apagar o adultério - enquanto em "Ponto de Crochê" nota-se maior ênfase na reelaboração mnêmica, já que a protagonista costura trechos de sua vivência, ainda que tal fazer apareça formalizado na reelaboração literária. A cerveja, ainda que seja um traço de menor relevância, também marca os dois protagonistas, porém em Jó Joaquim o cheiro da cerveja é bom e em Gabriel a cerveja é índice do alcoolismo, um dos fatores de ruína da família.

Os contos "A vela ao diabo" e "Ponto de Crochê" apresentam ligações mais brandas, tendo como ponto de contato a manipulação de discursos e fios. Dlena se apropria dos fios discursivos para persuadir Teresinho a se afastar da amada Zidica. "Aranha em jejum", ela tece a partir de sua fabulação argumentos que afastem os enamorados, preparando uma armadilha em sua teia; a personagem feminina de Dalton, busca, também semelhante a uma aranha, tecer malhas feitas da própria memória a fim de compreender seu presente e quiçá remendar o tecido afetivo que a liga a Gabriel e recobre a família, assim como cerze as meias que pendem da caixa de costura. Ela se faz uma aranha benfazeja, que, como aracne, só quer contar a própria história por meio de fios mnemônicos e têxteis.

"Colheita" e "Ponto de Crochê" possuem vínculos devido à postura de suas protagonistas que, apesar da ausência dos maridos, conseguem investir no cuidado com a própria subjetividade por meio da reflexão e dos cuidados domésticos. No conto de Nélida, no entanto, a mulher consegue empreender uma jornada de autoconhecimento e conquista de voz autônoma, já a tecelã de Dalton apenas esboça um percurso de subjetivação por meio da memória, sem chegar a assumir o poder sobre o seu discurso.

Há também um movimento de subversão nas duas personagens simbolizado pelo vestido vermelho ${ }^{77}$, que aponta para o processo de libertação das amarras

77 "Mas, com o tempo, além de mudar a cor do vestido, antes triste agora sempre vermelho, e alterar o penteado, pois decidira manter os cabelos curtos, aparados rentes à cabeça - decidiu por eliminar o retrato" (Piñon, 1997, p. 99); "Vestido vermelho de veludo, anéis nos dez dedos, uma pérola na orelha, mulher 
patriarcais, embora em "Colheita" a opção pelo vestido seja um dado concreto e em "Ponto de Crochê" a escolha espelhe um desejo da protagonista, rompido, aliás, pelo retorno de Gabriel.

Já "A Moça Tecelã" e "Ponto de Crochê" dialogam pela premência da atividade têxtil que parece reger o cotidiano das duas mulheres. Ambas se organizam enquanto sujeitos por meio da relação com a agulha e é também via tessitura que são capazes de avaliar seus elos com o outro e com o ambiente. É de se notar, entretanto, que se a moça de Colasanti usa as linhas para sonhar e construir o seu futuro, a mulher de Dalton usa as laçadas a fim de reconstruir seu passado. É ainda importante ressaltar que há uma similitude sensível na construção dos enredos, uma vez que ambos se articulam a partir de traços repetitivos que mimetizam o movimento da tecelagem. Contudo, tal repetição é estruturada de maneiras distintas, que revelam opções estéticas de seus autores. ${ }^{78}$

Os últimos dois elos da teia são as narrativas de Dalton Trevisan. Comentamos algumas afinidades das histórias que pertencem à mesma obra e, portanto, ao mesmo momento estético e histórico. Ambos os contos retratam casais suburbanos cujos problemas conjugais esgarçam o tecido afetivo e refletem um apequenamento da matriz mítica em função da ruína da cidade. As duas protagonistas parecem recorrer ao tricô e ao crochê como maneiras de urdir o silêncio imposto por suas vidas banais.

A elas cabem os cuidados domésticos e a gestão da rotina, não restando espaço para a própria autonomia e vivência da sexualidade. O marido do conto "Penélope" aniquila a esposa por meio dos ciúmes, enquanto o marido de "Ponto de Crochê" a apaga pela via do descaso. As duas narrativas narram tragédias burguesas em que o amor é esmagado pela rotina e as mulheres se veem, como suas antepassadas, obrigadas a tecer e fiar para encontrar algum sentido discursivo na existência. Vale notar que, em ambas, os papéis dos adúlteros também são

chorando na tarde, ponto de duas laçadas - o sorriso desdenhoso na lágrima. Guardou o novelo, a agulha, a toalha na cestinha. Ergueu o rosto para o corredor iluminado, os passos agora mais perto." (Trevisan, 2009, p. $137,138)$

\footnotetext{
78 "As imagens e situações que retornam como ecos reiteram a sensação de familiaridade, como se criassem uma memória própria e singular, como um dejá-vu literário. Mas a repetição, aqui, implica em diferença, e a oposição leva a caminhos divergentes também quanto à função social dos relatos. Nos contos de fadas e na tradição oral, a repetição é uma característica inerente ao gênero. Mas no âmbito do conto onde, assim como no romance, a ênfase recai sobre a originalidade e a inovação, a insistência na repetição por si só já aponta para uma dissonância." (Ribeiro, 2011, p. 15)
} 
invertidos, mostrando, ironicamente, que o adultério é uma constante nos casamentos burgueses. As duas protagonistas ainda assumem atitudes transgressoras, embora microscópicas e banais, a velha, ao surpreender o marido com o suicídio, e a mulher que faz crochê ao formular uma possibilidade de fuga da submissão patriarcal.

Aqui, após dispormos os textos do corpus em nossa teia, o trabalho poderia terminar. Contudo, há um fio que insiste e continua a produzir sentidos, merecendo relevo. Propositadamente, deixado para o final, ele encerra e abre novamente o jogo interminável do fiar o tecido e a palavra misturadamente (bem ao gosto de Rosa). Por escapar da ordem estrutural esperada da dissertação, ele vem como uma espécie de arremate não no sentido de conclusão, mas no de atar nós para reforçar as costuras "de modo imperfeito" (v. houaiss) e contínuo.

O trabalho que se iniciou na caixa de costura precisa uma vez mais retornar ao tecido a fim de demonstrar como o entrelaçamento das esferas têxtil e textual transcende a literatura e que, enfim, agulha e caneta podem conviver. 
Arremate: da agulha à palavra, da palavra à agulha

Canto às mulheres de Trás-os-Montes

$$
\begin{array}{r}
\text { Teces a camisa } \\
\text { na solidão das noites } \\
\text { quem ouve a tua voz } \\
\text { dilacerada? } \\
\text { (perdida entre os montes } \\
\text { na tua barraca...) } \\
\text { Teces o pranto } \\
\text { no interior dos olhos despertado } \\
\text { quem ouve o teu gemido } \\
\text { entrecortado? } \\
\text { (perdida entre os montes } \\
\text { na tua barraca...) } \\
\text { Teces o filho } \\
\text { no mais longo do corpo } \\
\text { quem ouve teu grito } \\
\text { amordaçado? } \\
\text { quem contará ao país } \\
\text { di o que foi passado? } \\
\text { (Maria Teresa Horta) } \\
\text { (perdida entre os montes } \\
\text { da tua barraca...) } \\
\text { num viver desesperado } \\
\text { E quando morreres } \\
\text { quála }
\end{array}
$$

Após tanto fiar, enlaçar meadas e colorir esse bordado de palavras e reflexões, faz-se necessário arrematar 0 trabalho de agulhas. Retomaremos algumas linhas puxadas ao longo do trabalho a fim de concluir algumas reflexões sobre os deslizamentos da figura da tecelã dentro do universo literário, lembrando que tais reflexões dialogam com a arte têxtil, nosso ponto de partida. $O$ foco, portanto, recairá no avesso do bordado, como requerido no arremate de uma boa bordadeira.

Depois de leituras e cotejamento do corpus, pudemos atestar que a reiteração do mito das tecelãs se apresenta de maneira bastante profícua na narrativa brasileira do século XX. Os contos analisados resgatam cada um, a sua maneira, a 
narrativa mítica e reencenam seus temas a partir de alterações que lhe atribuem novos sentidos.

Não encontramos Penélope, as Moiras, Ariadne, Calipso em seu estado épico, resguardadas em seu invólucro idílico, reencontramos tais figuras no sertão, no asfalto, em conflitos conjugais e tarefas domésticas. A aura idílica do mito é apequenada em sua encenação moderna, contudo, ainda é possível reconhecer seus ecos.

Também pudemos concluir que a organização do corpus em redes de relações não hierárquicas constituiu uma linha analítica produtiva, já que permitiu o diálogo entre todos os textos investigados, iluminando mais nitidamente suas semelhanças e diferenças. Essa organização propiciou não só que vislumbrássemos os paralelos de cada narrativa com os referenciais míticos, mas também um liame com cada uma das narrativas brasileiras.

Além disso, a opção metodológica nos permitiu perceber que em um mesmo texto mesclam-se traços de diversas tecelãs míticas, de modo a constatar que a retomada não opera de maneira pura, aspecto que torna a análise ainda mais rica. Em "A Moça Tecelã", encontramos Penélope e as Moiras, bem como traços de Ariadne; em "Desenredo", Calipso, Circe e Penélope; em "A vela ao diabo" a disputa de Penélope e Calipso. Esse desfile de tecelãs em um mesmo conto mostra que o mito é repaginado pela literatura que o assimila e desestabiliza os referenciais da tradição na construção de um novo texto.

Pudemos também verificar que a metáfora do tecer realmente simbolizou, em nosso corpus, tanto a criação literária, quanto restituiu um lugar discursivo para o feminino, ainda que em cada texto uma dessas esferas se sobressaia mais. Foi possível igualmente mapear que esse é um campo fértil para futuras pesquisas, sobretudo no que tange à literatura da América, uma vez que diversos autores como Laura Esquivel, Julio Cortázar, Margareth Atwood, Patrícia Bins e Érico Veríssimo, resgatam a temática do fio na construção de suas obras literárias e a análise não exauriu as possibilidades de interpretação dos textos do corpus.

Conforme já analisado, no capítulo inicial do trabalho, as mulheres sempre estiveram à frente dos ofícios têxteis e, a partir do advento da industrialização, em linhas gerais, a tecelagem foi sendo paulatinamente desvalorizada enquanto a cultura se sobrepunha à natureza. As mulheres do século $\mathrm{XX}$, análogas às escritoras aqui enfocadas, realizaram um profundo trabalho de revalorização do material têxtil, 
ao substituir agulhas por canetas e assumirem um novo espaço discursivo que ressignificasse os trabalhos domésticos, antes locus de confinamento. Dessa maneira, avaliamos de que modo existiu um deslocamento da atividade têxtil para a atividade textual por meio da metáfora, segundo o qual as figuras da tecelã e do narrador passaram a ser intercambiáveis.

Contudo, a ressignificação dos ofícios têxteis não parou no campo da literatura, expandindo-se para outras esferas e permitindo o retorno da agulha para o bastidor e para o tecido, revestida com o poder da palavra e da transgressão. Diversos trabalhos do campo das artes têxteis atestam essa mudança e, assim como no campo literário, os ecos reverberaram em todo o globo, embora nossa discussão tenha se centrado em alguns aspectos da questão, na América, a partir da década de 70 .

Embora a relação do bordado com a reinvindicação política date do movimento sufragista - conforme aponta Gilbert Lascault (2008, p. 25) em seu Figures Defigurées, a sufragette Janie Terreno bordou flores em um guardanapo no qual é possível ler os nomes das mulheres presas por atividades feministas - é na década de 70 que as técnicas têxteis retornam com mais força no campo da arte.

Nos Estados Unidos, a instalação de Judy Chicago Dinner Party (1974-1979) foi um marco na revalorização da arte têxtil. Nessa obra, a autora construiu um banquete para o qual foram convidados 39 grandes mulheres da história. Na mesa triangular foram dispostos 39 jogos americanos ricamente bordados com ilustrações e palavras que remetiam à trajetória de cada uma das figuras e sobre ele foi disposto um prato de porcelana em formato de vagina, juntamente com os copos e talheres para o jantar. No chão, a artista gravou o nome de 999 mulheres marcantes na história da humanidade, requisitando um reexame da história, a fim de valorizar essas figuras que haviam sido apagadas devido a seu gênero. Trata-se de uma obra impressionante por sua riqueza de detalhes e simbolismo. 


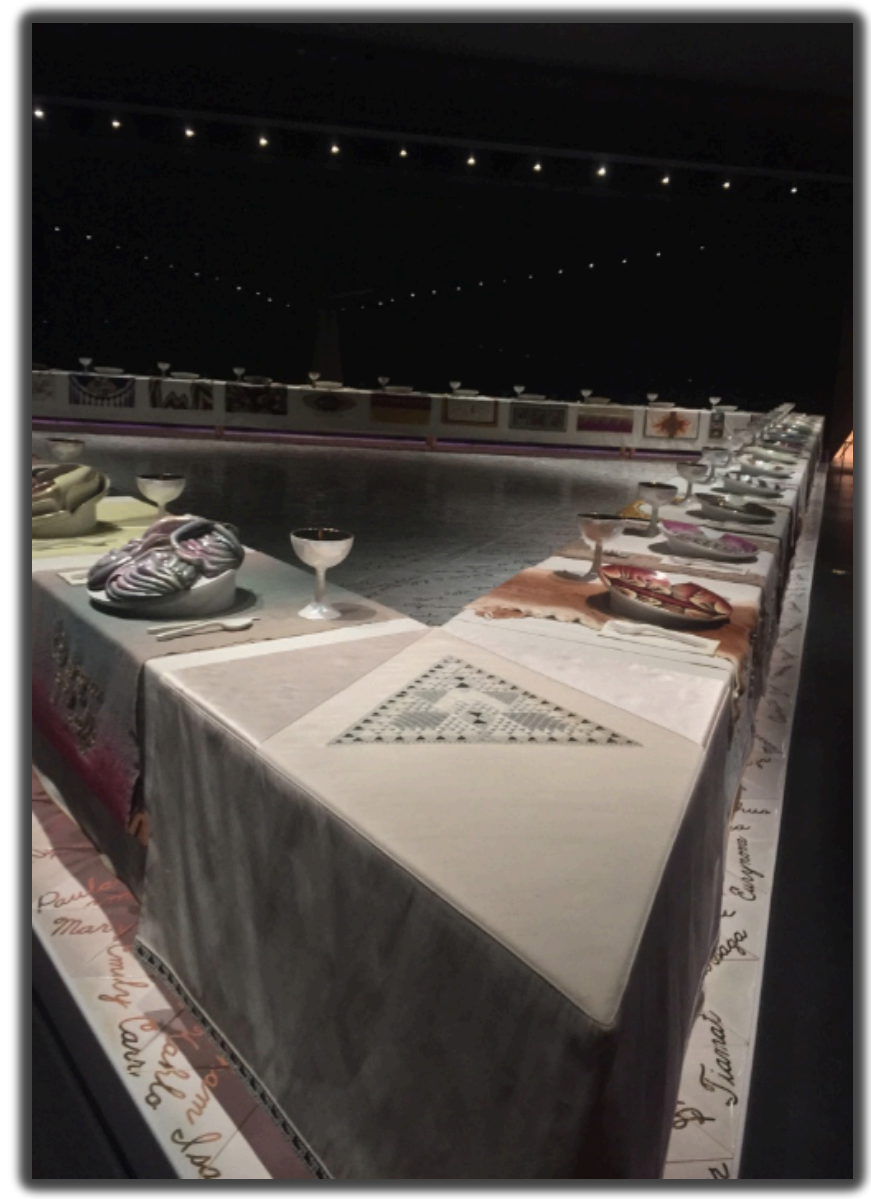

Figura 1- Dinner Party, Judy Chicago. Museu do Brooklyn. Acervo Pessoal.

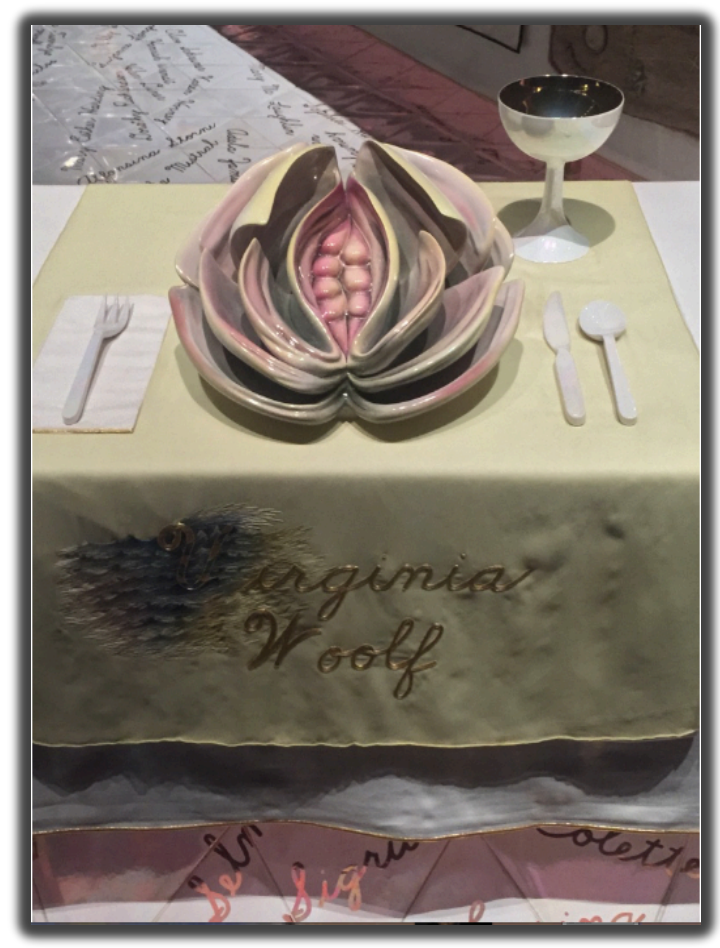

Figura 2- Close de Dinner Party, Judy Chicago. Museu do Brooklyn. Acervo Pessoal. 


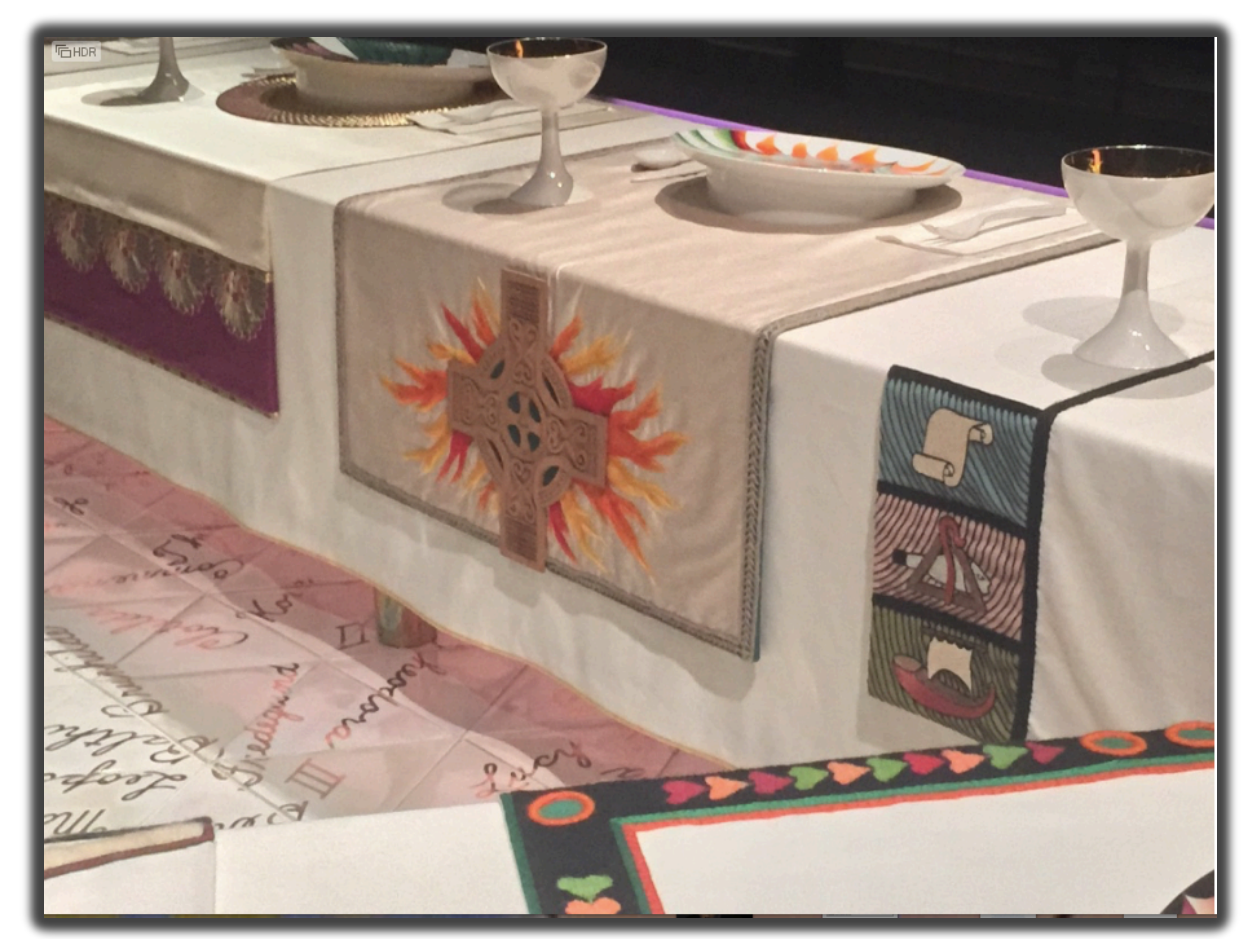

Figura 3- Bordados em Dinner Party, Judy Chicago. Museu do Brooklyn. Acervo Pessoal.

Atualmente a agulha, que já representou uma restrição da autonomia feminina, retorna aliada à palavra como instrumento de libertação e reivindicação de direitos. Retomar os bastidores e agulhas é também reivindicar um legado deixado por nossas avós e revalorizar a ancestralidade do feminino. Pegamos as agulhas com novos propósitos, mas honramos em cada laçada os pontos que cada mulher bordou para que pudéssemos ter arbítrio sobre as linhas de nossa mão.

No mundo moderno, regido pelo crescente individualismo, faz-se cada vez mais necessário redescobrimos a narrativa e os trabalhos manuais. Essas práticas parecem nos devolver um senso de coletividade e de pertencimento que a industrialização nos arrancou. Segundo Walter Benjamim (2014, p. 222), Leskov considerava a narrativa como um ofício artesanal, cuja dimensão manual precisava ser resgatada, posicionamento partilhado por Valéry. O poeta defende que a coordenação entre alma, olho e mão é uma característica partilhada pelo artesanato e pela palavra, o autor ainda se indaga se a relação do autor com a sua matéria (a vida humana) não seria uma relação artesanal, já que o artista capta essa vida humana, trabalha essas experiências como matéria-prima e as transforma em um produto artístico. ${ }^{79}$

\footnotetext{
${ }^{79}$ A alma, o olho, e a mão estão assim inseridos num mesmo contexto. Interagindo, eles definem uma prática. Essa prática deixou de nos ser familiar. O papel da mão no trabalho produtivo tornou-se mais modesto, e o lugar que ela ocupava durante a narração está agora vazio. (...) A antiga coordenação da alma, do olho e da
} 
No Brasil do século XXI, vemos diversos grupos de bordadeiras, tradicionais e modernas, que recuperam os fios tanto como contação de histórias, como bandeiras de resistência. Entre eles, falaremos das Bordadeiras da Terceira Idade Estrela do Sertão, do grupo Matizes Dumont, do movimento de Arpilleras contra as barragens e do Clube do Bordado. São todos coletivos de mulheres que resgatam a arte têxtil a partir de um novo lugar discursivo, acrescentando novos matizes de cores às histórias da tecelagem e da narrativa.

O Bordadeiras da Terceira Idade Estrela do Sertão é um grupo sediado no Museu Casa Guimarães Rosa que utiliza a técnica do bordado para ilustrar paisagens, elementos e fragmentos da obra do escritor. Esse trabalho reaproxima a literatura e a tecelagem, imbricando-as. Segundo a curadoria do museu, o projeto surgiu em 2003 e estimula a criatividade das bordadeiras que retratam elementos da fauna e da vegetação do sertão para além dos excertos da obra rosiana.

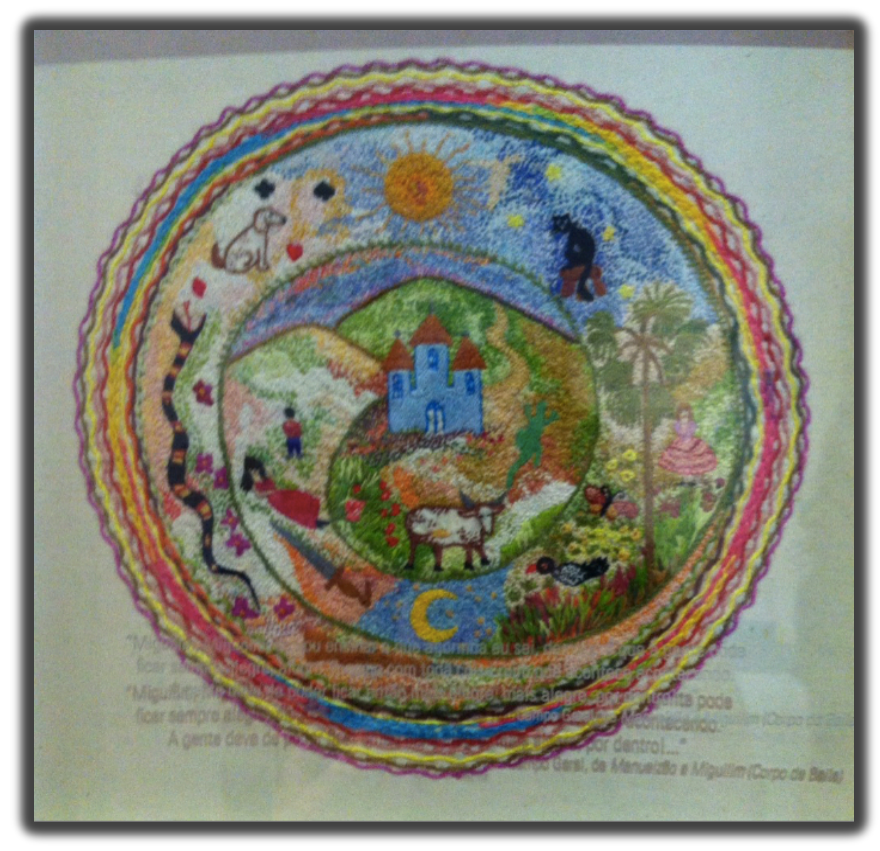

Figura 4- Bordado Inspirado em Manuelzão e Miguilim do Grupo Estrelas do Sertão. Casa Museu Guimarães Rosa. Acervo Pessoal.

mão, que transparece nas palavras de Valéry, é típica do artesão, e é ela que encontramos sempre, onde quer que a arte de narrar seja praticada. Podemos ir mais longe e perguntar se a relação entre o narrador e sua matéria - a vida humana - não seria ela própria uma relação artesanal. Não seria sua tarefa trabalhar a matéria-prima da experiência - a própria e a alheia - transformando-a num produto sólido, útil e único? (Benjamin, 2014, p. 239) 


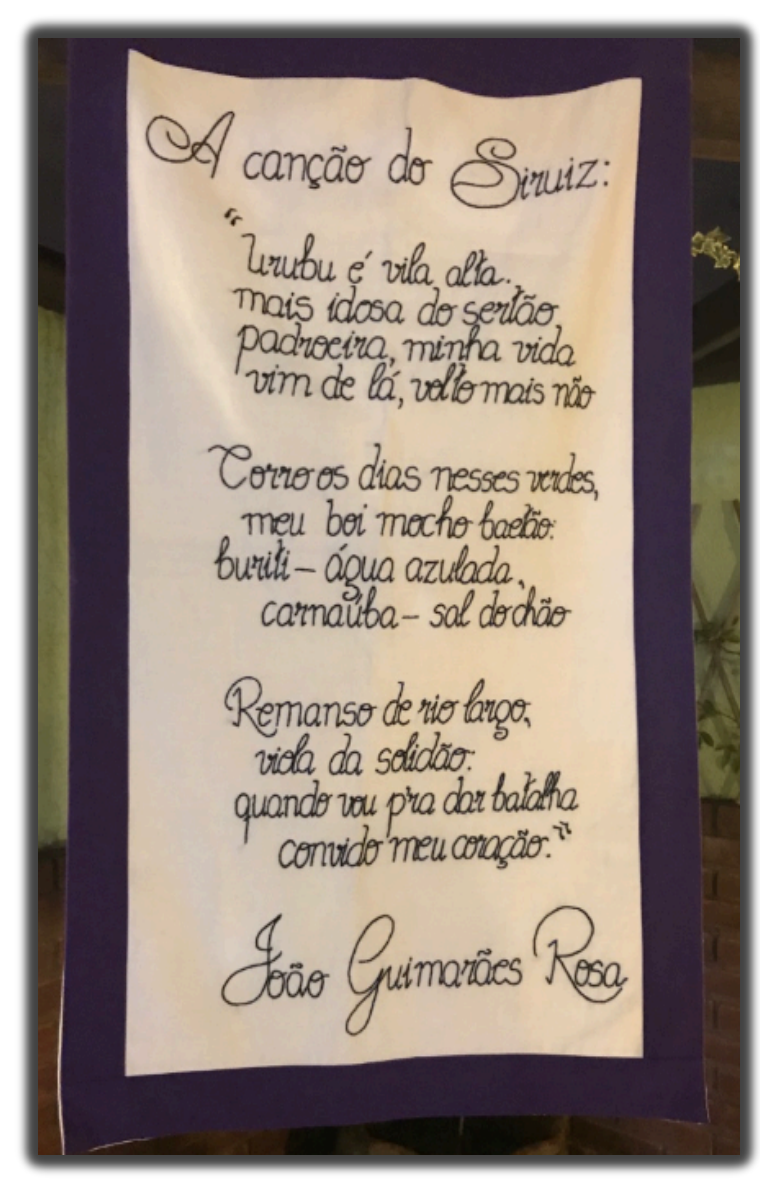

Figura 5- Bordado Inspirado em Grande Sertão: Veredas do Grupo Estrelas do Sertão. Peça comprada em Cordisburgo. Acervo Pessoal.

O grupo Matizes Dumont é um dos grupos mais significativos engajados com a arte do bordado. Fundado há 30 anos, o grupo invoca temas e paisagens brasileiras em seus trabalhos, valorizando a cultura popular. Esse grupo foi responsável pelas ilustrações da edição infantil do conto “A Moça Tecelã”.

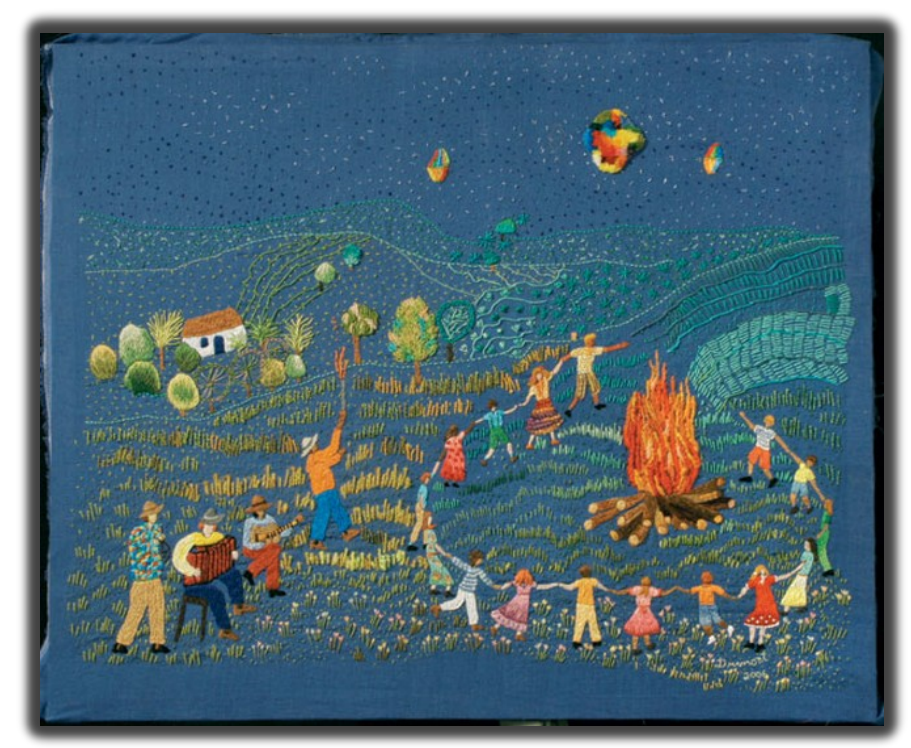

Figura 6- Festa de São João do Grupo Matizes Dumond. https://www.matizesdumont.com/collections 


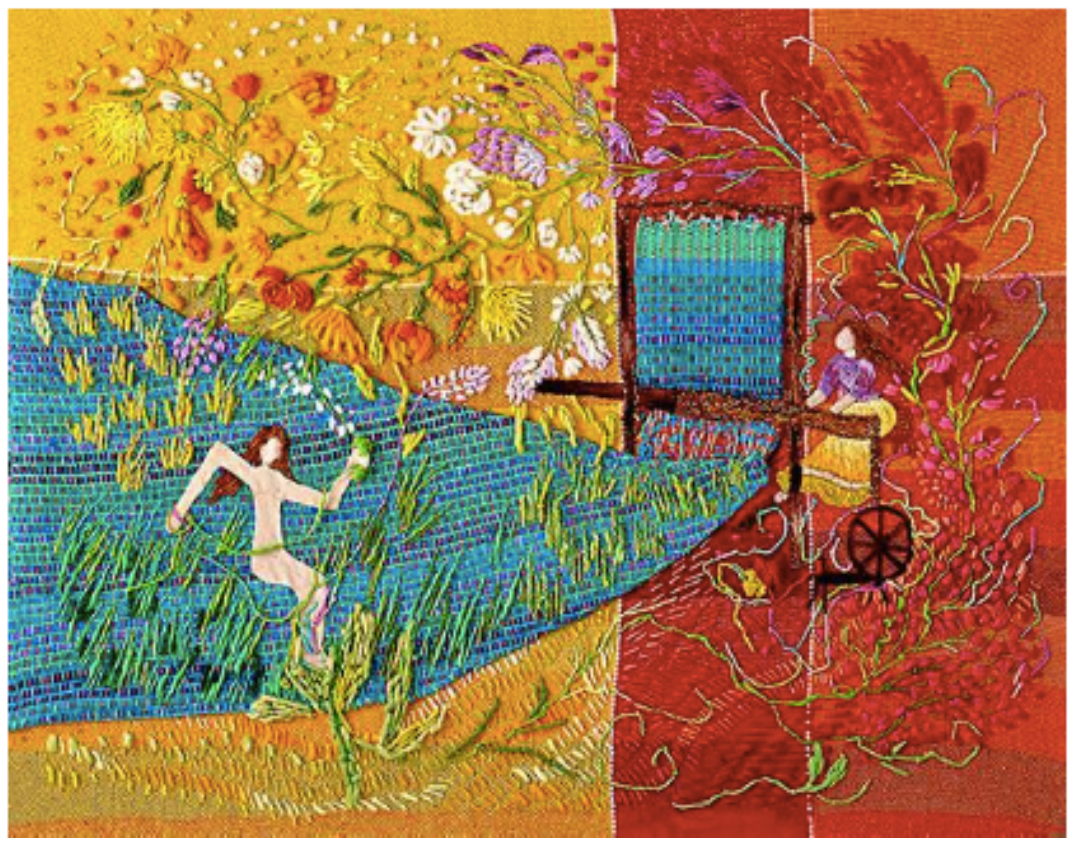

Figura 7- Tecendo a Vida Bordadeira do Grupo Matizes Dumond. https://www.matizesdumont.com/collections

Bordado Riot ou bordado feminista é um fenômeno têxtil que vem se intensificando na última década. Essa linha do bordado recupera temas considerados tabus na sociedade e os aplicam com as técnicas tradicionais de bordado, de modo que, ao invés dos motivos florais e da natureza, o bordado riot representa a auto-aceitação, as partes do corpo, palavras de ordem, palavrões, cenas eróticas e reinvindicações políticas.

Um grupo que representa esse movimento e que vem ganhando destaque na cena nacional é o Clube do Bordado. Esse coletivo foi formado por seis mulheres que decidiram aprender juntas a técnica do bordado em reuniões semanais. À medida que aprendiam, iam discutindo temas do cotidiano e das relações com o próprio corpo e com a feminilidade, acabando por refletir tais temas nos bordados. Em 2013, o grupo determinou sua marca oficial, passando não só a comercializar produtos, mas também a promover cursos e vídeos de difusão da técnica do bordado. 


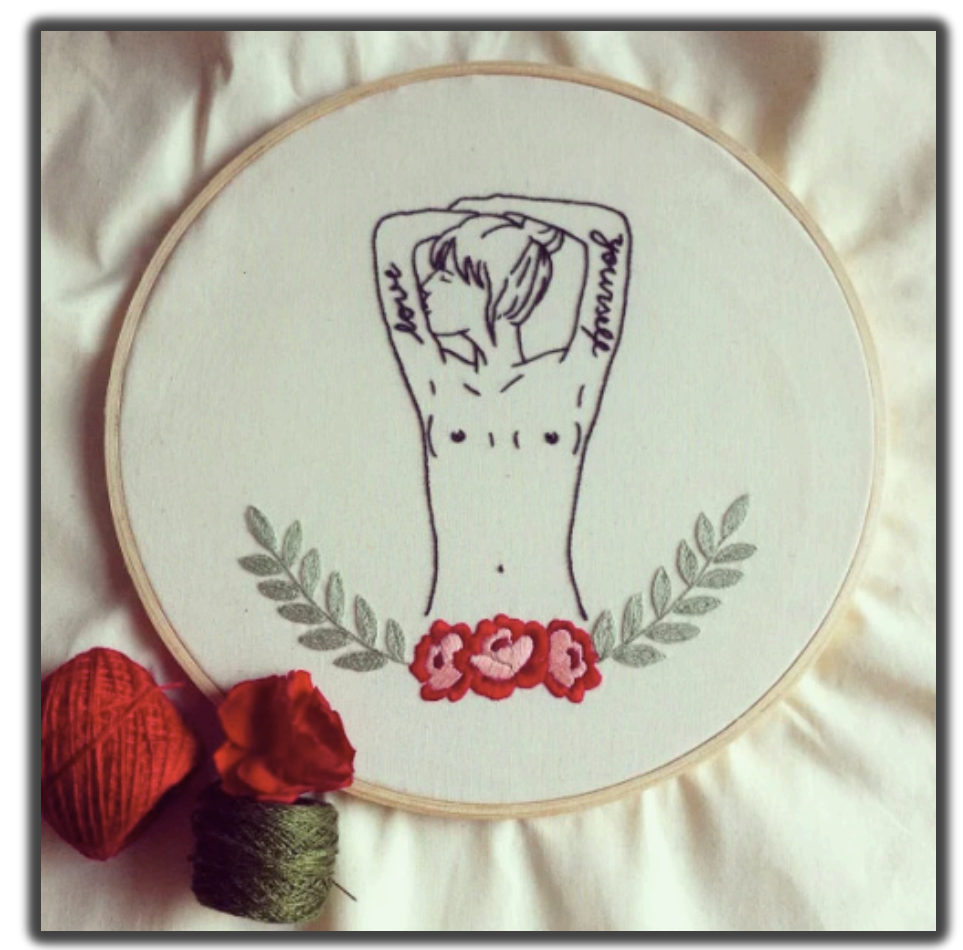

Figura 8- Love Yourself do Grupo Clube do Bordado. http://www.oclubedobordado.com/galeria

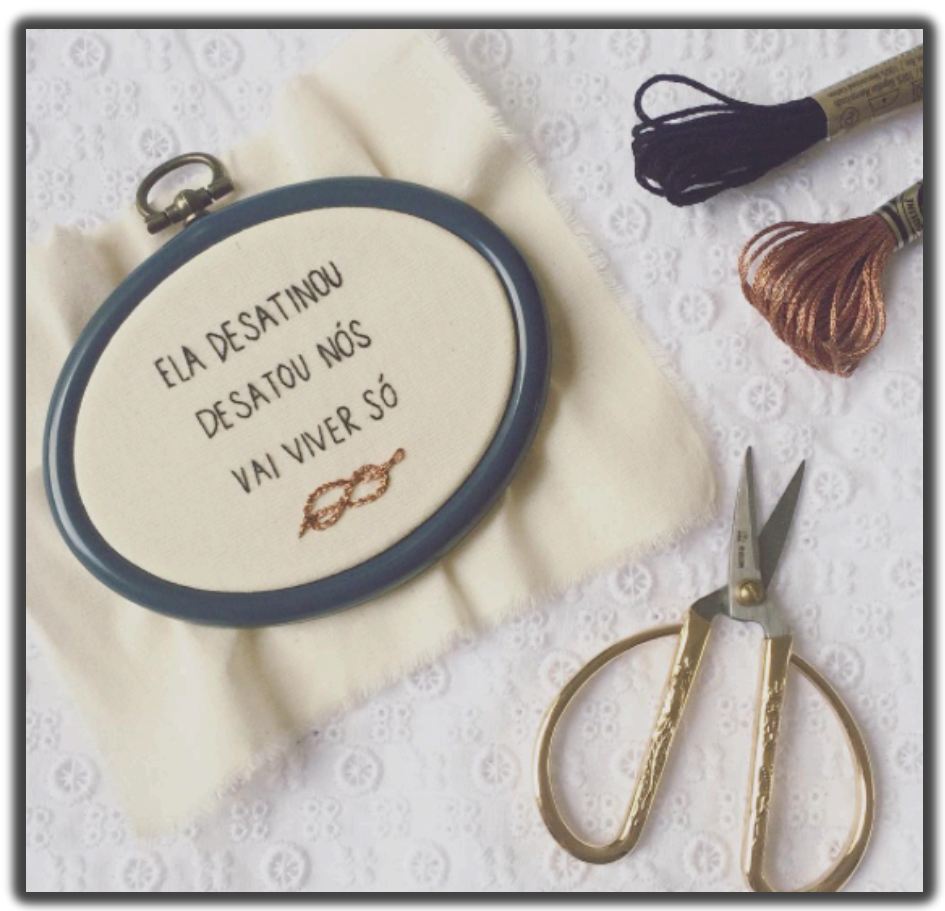

Figura 9- Ela Desatinou do Grupo Clube do Bordado. http://www.oclubedobordado.com/galeria 


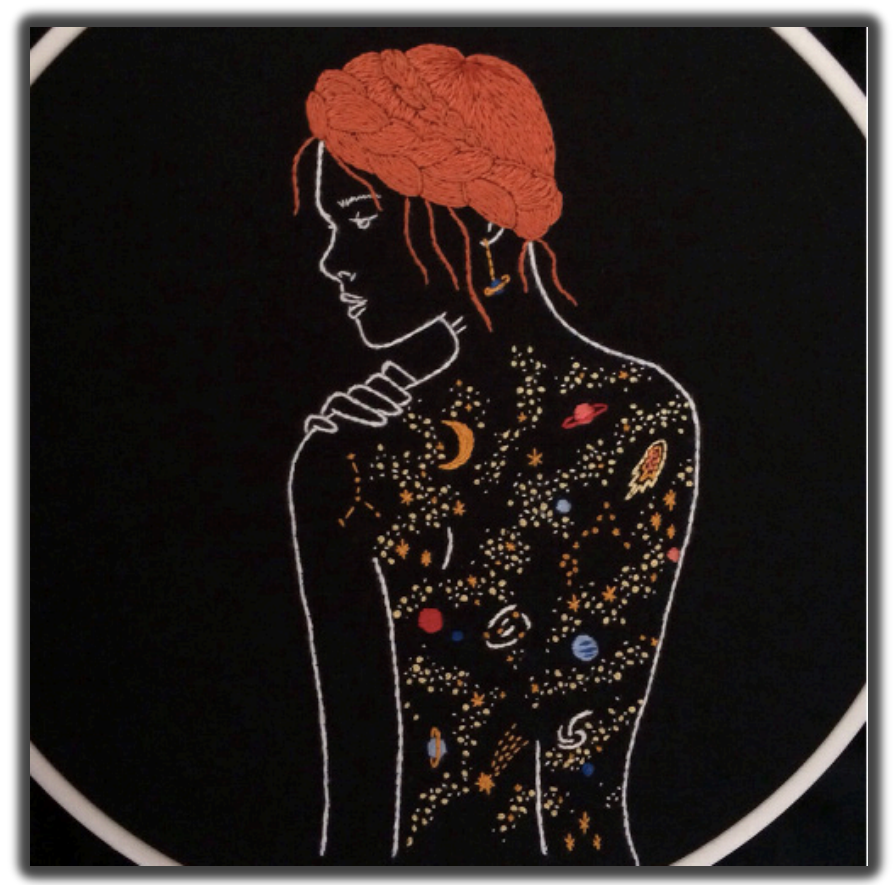

Figura 10- Universo do Grupo Clube do Bordado. http://www.oclubedobordado.com/galeria

No Chile, um movimento artístico e político fulcral, no final do século $X X$, foi a Arpillera. Essa técnica, surgida no litoral chileno, consiste na composição de desenhos e reinvindicações políticas realizada em retalhos de tecido, costurados com relevos e pequenas bonecas que representam as autoras da obra. A técnica surgiu durante a ditadura militar de Pinochet e tinha como objetivo denunciar os abusos do sistema autoritário, sobretudo no que tangia aos desaparecidos políticos. Os trabalhos formaram um espaço de resistência importante, transformando o papel da costura naquele período ao registrar a memória, o testemunho e a luta política.

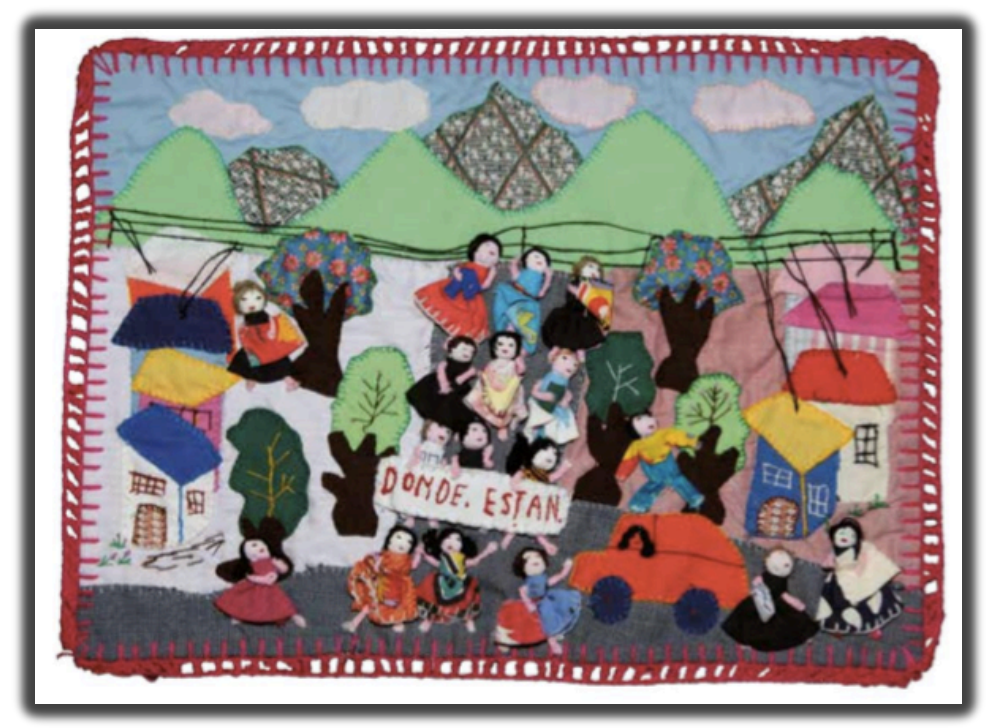

Figura 11- Coleção Conflict Textiles. Foto: Martim Melaugh. Origem: Theresa Wolfwood, Canadá 


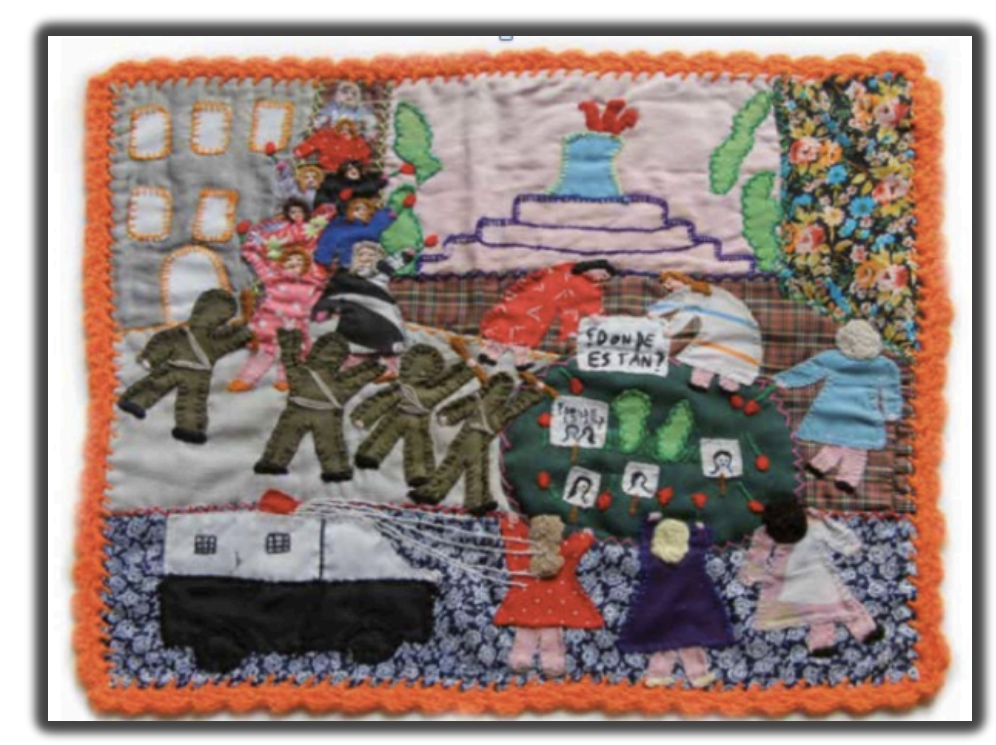

Figura 12- Coleção Conflict Textiles. Foto: Tony Boyle. Origem: Joanne Sheeran, EUA

Atualmente no Brasil, tal técnica é retomada pelo Movimento dos Atingidos por Barragens. Em suas Arpilleras, as mulheres denunciam as violações aos direitos humanos sofridos pelos atingidos. Tal movimento ganhou tanta força que participou, em 2015, no Memorial da América Latina, da exposição "Arpilleras: bordando a resistência", reunindo 37 peças de bordado construídas por mulheres de seis países da América Latina e Europa, a fim de recolocar o papel de resistência das artes têxteis. A exposição está em vias de se tornar um documentário, em que o cotidiano dessas mulheres e sua sabedoria serão eternizados em vídeo.

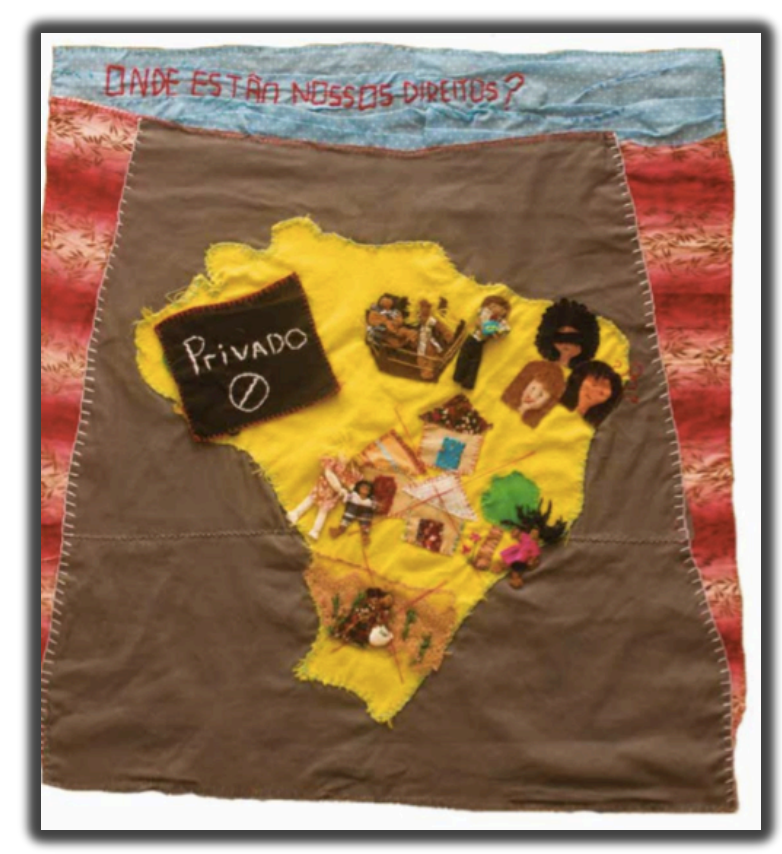

Figura 13- Coleção do Movimento dos Atingidos por Barragens (MAB). Foto: Vinícius Denadei. 


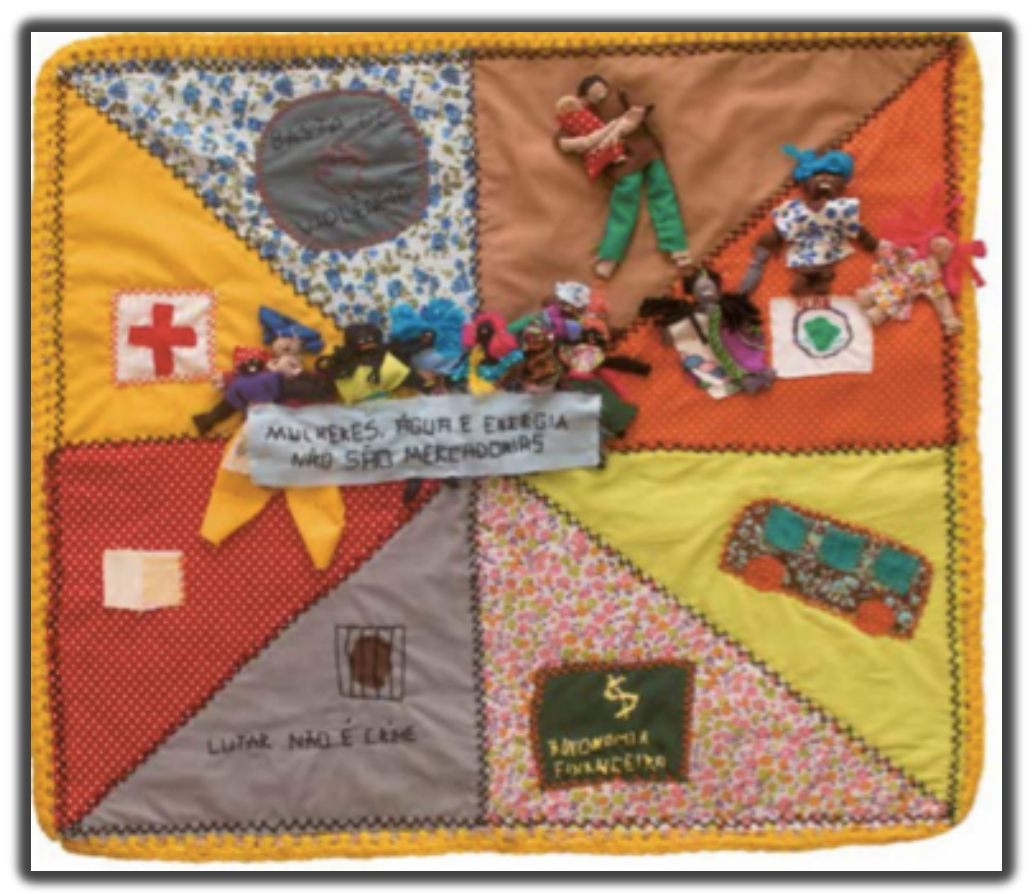

Figura 14- Coleção do Movimento dos Atingidos por Barragens (MAB). Foto: Vinícius Denadei.

Por meio desses breves exemplos, podemos vislumbrar que a íntima relação entre tessitura, narrativa, resistência e luta por um lugar discursivo transcendem a literatura. A palavra e a agulha tornaram-se aliadas nos ofícios têxteis e textuais a fim de costurar destinos com o pano fino da liberdade. Penélope retorna feliz ao seu tear, completa por ser dona de si e poder entremear fios e palavras conforme seus desejos. Afirmando sua liberdade, a sensata Penélope combina as cores, configura as formas e urde com delicadeza novas bandeiras para lutar por seus direitos. 


\section{Ulisses, o retorno}

Como voltar

depois de Itaca

das sereias

dos ciclopes

de tanto assombro

de tanto sangue na espada?

Como voltar

se aquele que partiu

partiu-se

e voltará os fragmentos do excesso?

Não há retorno

Há outra viagem

diariamente urdida

dentro da viagem

antiga.

Embora o caminho

da volta

seja percorrido

ninguém retorna

apenas volta a viajar

no espaço anterior

estranhamente familiar.

Como se o regresso

fosse acréscimo

e o viajante descobrisse

que é atrás

que está a fonte

e na alvorada

o horizonte

não há retorno.

Há o contorno

do próprio eixo

o tempestuoso

périplo do ego

um diálogo de ecos

como quem

tenta encaixar

diferentes rostos

no mesmo espelho.

Por isto, o retorno

inelutável

é perigoso

exige mais perícia

que na partida

mais destreza

que nos conflitos

pois o risco

é naufragar

exatamente

quando chegar ao porto.

(Afonso Romano Sant'Ana) 


\section{Bibliografia}

ALMEIDA, Lélia. Cozinhar é igual a tecer que é igual a narrar: três habilidades recorrentes na literatura de autoria feminina. Especulo. Revista de estudos literários.Universidad Complutense de Madrid, 2004.

ARAUJO, Katiane. "Tecendo o mundo em palavras: uma analogia à composição literária" REEL - Revista Eletrônica de Estudos Literários, Vitória, s. 2, ano 9, n. 12, 2013. 1

BARROS, Liliane e AQUINO, Paula. "Categorias narrativas e figura feminina no conto "Colheita", de Nélida Piñon" REEL - Revista Eletrônica de Estudos Literários, Vitória, s. 2, ano 7, n. 8, 2011.

BARTHES, Roland. Mitologias. Rio de Janeiro: Difel, 2012.

BEAUVOIR, Simone de. O segundo sexo. Rio de Janeiro: Nova Fronteira, 2009.

BELUQUE, Maria Helena e FERNANDES, Célia Regina. "Reencantos e Ressignificações no conto de fadas contemporâneo: uma análise de A Moça Tecelã". Anuário de Literatura, ISSNe: 2175-7917, vol. 16, n. 1, p. 171-185, 2011

BENJAMIN, Walter. Obras escolhidas, vol.l- Magia e técnica, arte e política: ensaios sobre literatura e história da cultura. São Paulo: Editora Brasiliense, 2014.

BERGREN Ann. Weaving Truth: Essays on Language and the Female in Greek Thought. Washington: Center for Hellenic Studies, Harvard University, 2008.

BERNARDINI, Aurora F e FERREIRA, Jerusa P. (ORG.) Mitopoéticas: da Rússia às Américas. São Paulo: Humanitas, 2006.

BEZERRA, Luciana da Silva. Penélopes do contemporâneo na escrita de Juana Ruas e Lídia Jorge. Dissertação de Mestrado em Literatura Portuguesa - Rio de Janeiro : Faculdade de Letras, Universidade Federal do Rio de Janeiro, 2006.

BOSI, Alfredo. "A interpretação da obra literária". In: Céu, Inferno. São Paulo: Ed. Duas Cidades; Ed. 34, 2010.

BOURDIEU, Pierre. O Poder Simbólico. Rio de Janeiro: Bertrand Brasil, 1998.

BRUNEL, Pierre. Dicionário de Mitos Literários. Rio de Janeiro: José Olympio, 2005.

Rocher, 2002.

Dictionnaire des mythes féminins. Paris: Éditions du 
CAMPELLO, Eliane. "A tessitura da escrita: do mito à expressão pela arte", Interdisciplinar Ano 3, v. 7, no. 7-57, Jul/Dez de 2008, , p. 43

CARDOSO, Zelia de Almeida. "O artesanato Feminino em Roma e os Textos Antigos: Fiandeiras e Tecelãs". In Calíope 14, 2006, Rio de Janeiro: pp. 92-109

CARVALHAL, Tania Franco. "Encontros na travessia". In Literatura e Sociedade. Universidade de São Paulo, Faculdade de Filosofia, Letras e Ciências Humanas, Departamento de Teoria Literária e Literatura Comparada. Número 09, São Paulo, 2006.

CARVALHO, Lívia Maria Rosa "A representação da menina e da mulher no conto de fadas moderno: novos destinos em "Além do bastidor" e "A moça tecelã" de Marina Colasanti"” Signo. Santa Cruz do Sul, v.40,n. 68,p. 75-83, jan./jun. 2015.

CASAGRANDE, Sarah e ZOLIN, Lúcia. "A representação da mulher no conto Colheita, de Nélida Piñon: mulher emancipada." Acta Sci. Human Soc. Sci. Maringá, v. 29 , n. 1 , p. $15-22,2007$

CHEVALIER, J. Dicionário de Símbolos. Rio de Janeiro: José Olympio, 1994.

COLASANTI, Mariana. "A Moça Tecelã". In: Um Espinho de Marfim e outras histórias. Porto Alegre: L\&PM, 2009.

COMITTI, Leopoldo. Anjo Mutante-O espaço urbano na obra de Dalton Trevisan. Literatura e Sociedade, n. 1, p. 81-87, 1996.

CORTÁZAR, Julio. "Circe". In: Bestiário. São Paulo: Editora Edibolso, 1977.

COUTINHO, Maria Lúcia. Tecendo Por Trás dos Panos - a mulher brasileira nas relações familiares. Rio de Janeiro: Rocco, 1994.

CURY, Maria Zilda Ferreira. "Espaços virtuais: O desenredo de Rosa, o desafio de Jó." UFMG. Revista O eixo e a roda. volume 07, 2001.

DERRIDA, Jacques. A Escritura e a Diferença. Trad. Maria Beatriz M.N. da Silva. 3. ${ }^{a}$ ed., São Paulo: Ed. Perspectiva, 2002

A Farmácia de Platão. Trad. Rogério da Costa. São

Paulo: lluminuras, 2015

DÉTIENNE, Marcel, VERNANT, Jean Pierre. Métis- As astúcias da inteligência. Odysseus, 2008.

DIOGO, Sarah Maria Forte. Entre o Machado e o Punhal: Configurações da Violência em Tutaméia (Terceiras Estórias) de João Guimarães Rosa. Tese. Belo Horizonte, UFMG, 2012. 
DUARTE, Adriane da Silva. "A relação entre retorno e glória na Odisseia". Letras Clássicas, n05, p. 89-97, 2001.

DUBY, Georges. PERROT, Michelle. (dir.). História das Mulheres no Ocidente, v. 1 : Antiguidade. Porto: Afrontamento, 1993.

DUMITH, Denise. O mito de Penélope e sua retomada na literatura brasileira : Clarice Lispector e Nélida Piñon. Tese de Doutorado. Universidade Federal do Rio Grande do Sul. Instituto de Letras. Programa de Pós-Graduação em Letras, 2012

DURAND, Gilbert. As Estruturas Antropológicas do Imaginário. Tradução: Hélder Godinho. São Paulo: Martins Fontes, 2002.

A Fé do Sapateiro. Brasília: Editora Universidade de Brasília, 1995. Mito e Sociedade. Lisboa: A Regra do Jogo, 1983.

FREUD, Sigmund. "O Tema dos Três escrínios". In: Obras Psicológicas Completas de Sigmund Freud, Volume XII (1911-1913). Rio de Janeiro: Imago Editora LTDA, 1990.

Psicopatologia da Vida Cotidiana. Rio de Janeiro: Imago

Editora LTDA, 1990.

FRYE, Northrop. Anatomia da Crítica. São Paulo: É Realizações Editora, 2014

GALVÃO, Walnice. "Metáforas Náuticas". Revista do Instituto de Estudos Brasileiros, São Paulo. Ed 41,1996, pp. 123-130

GAMA, Mônica. O Presente da Leitura: Beleza e Contradição. ALEA, Rio de Janeiro, vol. 14/2, p. 307-323, 2012.

GLISSANT, Édouard. Poética da Relação. Porto: Editora Sextante, 2011.

GRUBER, Cláudia. De Dinorá às mocinhas do passeio: As guerras conjugais no universo boêmio de Dalton Trevisan. Dissertação de Mestrado. Universidade Federal do Paraná, Programa de Pós- Graduação em Letras, Curitiba, 2007.

GUILLÉN, Claudio. Entre lo uno y lo diverso. Introducción a la literatura comparada. Barcelona: Editorial Crítica, 1985.

"Lo uno con lo diverso: Literatura y complejidad", Alicante: Biblioteca Virtual Miguel de Cervantes, 2006. : Edición digital a partir de 1616: Anuario de la Sociedad Española de Literatura General y Comparada, Vol. IX (Año 1995), pp. 51-66 
HESÍODO, Teogonia. Tradução: Jaa Torrano. São Paulo: Editora lluminuras, 1995.

HOMERO, Odisseia. Tradução: Frederico Lourenço. Lisboa: Editora Cotovia, 2010.

IZOLAN, Mauricio. A traição da tra(d)ição: o adúltero desenredo. Revista de Letras da Universidade Católica de Brasília. Volume 2, número 1, ano II, 2009.

JOLLES, André. Formas Simples. São Paulo, Cultrix, 1930.

JUNIOR. Antonio Barros de Brito. Signo, Metáfora e Verdade a partir de "Sobre verdade e mentira no sentido extra-moral" de Nietzsche". In RevLet -Revista Virtual de Letras Volume 1, Número 1/2009.

KAMENSZAIN, Tamara. "Bordado y Costura del Texto". Revista de la Universidad UNAM. No. 3 Julio (1981).

KRISTEVA, Julia. Introdução à Semanálise. São Paulo: Editora Perspectiva, 1974.

KULTOV, Barbara. A tecelã. São Paulo: Cultrix, 1990.

LASCH, Christopher. A mulher e a vida cotidiana - amor, casamento e feminismo. Rio de Janeiro: Civilização Brasileira, 1999.

LLANSOL, Maria Gabriela. O Livro das Comunidades. Lisboa: Relógio D`água Editores, 1999.

LAURENT, Jenny. "A estratégia da forma” In: Poétique n²7 (intertextualités). Livraria Almedina: Coimbra, 1979.

LÉVI-STRAUSS. "A estrutura dos mitos". In: Antropologia Estrutural. São Paulo: Cosac Naify, 2008.

LUKÁCS, G. "O romance como epopéia burguesa". Ad Hominem, n. 1, São Paulo, 1999.

MACHADO, Alleid Ribeiro. "Caminhos de transformação e ruptura em Colheita, de Nélida Piñon" Revista Graphos v. 14, n. 2, UFPB, 2012.

MACHADO. Ana Maria. Texturas sobre leituras e escritos. Rio de Janeiro: Nova Fronteira, 2001.

Recado do Nome. Rio de Janeiro: Nova Fronteira,

2003.

MENESES, Adélia Bezerra de. As Portas do Sonho. Granja Viana: Ateliê Cultural, 2002. 
MICHELLI, Regina. "O maravilhoso e o insólito nos contos de Marina Colasanti" O insólito em questão - Simpósios - Publicações Dialogarts, 2009

MIELIENTINSKY, E. M. A Poética do Mito. Rio de Janeiro: ForenseUniversitária, 1987.

MONTAGNA, Vera R. F. " "Desenredo" de Guimarães Rosa: descobertas de uma leitura”. Ide (São Paulo) vol.34 no.52 São Paulo ago. 2011

MOREIRA, Teresinha Taborda. "Imagens em ruínas, identidades reinventadas: uma leitura de "Colheita", de Nélida Piñon. SCRIPTA, Belo Horizonte, v. 18 , n. 35 , p. $35-46$, 20 sem. 2014

MOSSÉ, Claude. La Femme dans la Grèce antique. Albin Michel, Paris, 1983.

NICOLATTO, Roberto. "Em Busca de Curitiba Perdida: resistência e memória no inventário de Dalton Trevisan.". In Revista Letras, Curitiba, n. 64, p. 125-141. set./dez. 2004. Editora UFPR

NIETZSCHE, Friedrich. "Sobre verdade e mentira no sentido extra-moral". In: Os Pensadores. São Paulo: Abril Cultural, 1873.

NITRINI, Sandra. Literatura comparada (história, teoria e crítica). São Paulo: Edusp,1997.

NOVIS, Vera. "De Jó a Jó: Popa a Proa (Leitura de "Desenredo"). In: Tutaméia engenho e arte. São Paulo: Editora da Universidade de São Paulo, Perspectiva, 1989.

NUNES, Benedito. "Tutameia”. In: O dorso do tigre. São Paulo: Editora 34, 2009.

OLIVEIRA, Sueli Maria de. "Tessituras míticas em "Colheita" de Nélida Piñon" Darandina - UFJF. Volume 3 - Número 1 - Comunicações do Simpósio Internacional de Literatura, Crítica, Cultura IV: Interdisciplinaridade, Novembro de 2010.

PACHECO, Ana Paula. "Duas Lobas". In Literatura e Sociedade. Universidade de São Paulo, Faculdade de Filosofia, Letras e Ciências Humanas, Departamento de Teoria Literária e Literatura Comparada. Número 09, São Paulo, 2006.

PAGEAUX, Daniel-Henri. Musas na encruzilhada. Org. Marcelo Marinho, Denise Almeida Silva, Rosani Ketzer Umbach. São Paulo: Hucitec; Santa Maria: UFSM, 2011.

PASSOS, Cleusa Rios Pinheiro. "O contar desmanchando... artifícios de Rosa. In: Outras Margens: Estudos da obra de Guimarães Rosa. Org: Lélia Parreira Duarte. Belo Horizonte: Autêntica/ PUC Minas, 2001, pp. 21-36. 
Do feminino e suas estórias. São Paulo:

Hucitec, 2000.

PEDROSA, Andressa Teixeira "A Moça Tecelã: uma voz dissonantemente transgressora", RESET, V.1, N.2, 2008, pp. 26-33

PERRONE-MOISÉS, Leyla. "Literatura comparada, intertexto e antropofagia". In: Flores da escrivaninha. São Paulo: Companhia das Letras, 1990.

PIÑON, Nélida. "Colheita". In: Sala de Armas. Rio de Janeiro: Nova Fronteira, 1997.

RIBEIRO, Marília Scaff Rocha. Dalton Trevisan e a Poética da Repetição. Revista Letras, Curitiba, nº 84, p. 11-27, Editora da UFPR, jul-dez/2011.

ROCHA, Marília Librandi. "A Trama do Desejo: Uma Leitura do conto "Desenredo", de Guimarães Rosa." Revista Magma n. 06, p. 79-86, 1999.

RODRIGUES, Danielle Santos e SANTOS, Josalba Fabiana. "Velando: A mulher diabo em uma estória de Guimarães Rosa.". Revista Entrelinhas Vol. 7, n. 2 jul./dez. 2013.

ROSA, João Guimarães. "Desenredo" e "A vela ao diabo". In: Tutaméia (Terceiras estórias). Rio de Janeiro: Nova Fronteira, 2001.

ROSENFELD, Anatol. "À procura do mito perdido". In Letras e Leituras. São Paulo: Perspectiva, 1994. "Reflexões sobre o romance moderno". In Texto e Contexto. São Paulo: Perspectiva, 1973.

ROZENDO, A.da S., \& ALVES, J.M.,. Sexualidade na terceira idade: tabus e realidade. Revista Kairós Gerontologia,18(3), pp. 95-107, São Paulo, jul/set, 2015

RUTHVEN, K. K. O Mito. São Paulo: Perspectiva, 2010

SAMOYAULT, Tiphaine. A intertextualidade. São Paulo: Hucitec, 2008.

SANDRINI, Elizabete. "No (des) tecer do texto: a marca das relações de gênero no fio do destino feminino em A moça tecelã de Marina Colasanti". Littera Online Universidade Federal do Maranhão Número 08 - 2014

SILVA, Antonia Marly Moura da e MANGUEIRA, José Vilian. "Arquétipos da dualidade feminina no conto "Desenredo" de João Guimarães Rosa. In Letras de Hoje, Porto Alegre, v. 47, n. 2, p. 194-200, abr./jun. 2012 
SIMÕES, Maria Cláudia. "Desfiando as amarras patriarcais: a subversão do mito de Penélope em "A Moça Tecelã", de Marina Colasanti. Revista Garrafa 24 ISSN 1809-2586 maio-agosto de 2011

SOUZA, Neila da Silva de e CAVALCANTE, Elton Emanuel. "Diálogo intertextual entre os contos "Colheita" e "Penélope". Anais do 3o SILIC - Simpósio de Literatura Brasileira contemporânea, 2012

STIERLE, Karl. A ficção. Organização de Carlinda Fragale Pate Nuñez e Francisco Venceslau dos Santos. Tradução de Luiz Costa Lima. Rio de Janeiro: Caetés, 2006. (Novos Cadernos de Mestrado, v. 1).

TREVISAN, Dalton. "Penélope". In Vozes do Retrato. São Paulo: Editora Agir, 1998 "Ponto de crochê". In Novelas Nada Exemplares. São Paulo: Editora Atica Editorial, 2009

TROUSSON, Raymond. Thèmes et Mythes. Bruxelas: Éditions de l'Université de Bruxelles, 1981.

TURCHI, Maria Zaira. Literatura e Antropologia do Imaginário. Brasília: Editora Universidade de Brasília, 2003.

VERRI, Valda Suely da Silva. "Guimarães Rosa e uma visão sobre a oralidade". Revista Boitata, v 02, 2006.

WOOLF, Virginia. "A cortina da babá Lugton". In: Contos completos: Virginia Woolf.

São Paulo: Cosac Naify, 2009

ZENIL, Josefa da Silva. As laçadas da linguagem: fluxo de consciência e dialogismo em Ponto de Crochê , de Dalton Trevisan UFMT Revista Diálogos 2013 ZOLIN, Luciana. "A representação da mulher na narrativa de Nélida Piñon" Interdisciplinar. Ano 3, v. 5, no. 5 - Jan - jun de 2008

ZOLIN, Lúcia; JACOMEL, Carolina; PAGOTO, Cristina e MOLINARI, Soraya. "Violência Simbólica e Estrutura de Dominação em A Moça Tecelã". Graphos. João Pessoa, v. 9, n. 2, 2007 - ISSN 1516-1536 
Apêndice: Ariadne e o labirinto: notas sobre a tensão Mito - Modernidade

\author{
"Na vida da raça humana, \\ o mítico é um estágio antigo e primitivo, \\ ao passo que na vida do indivíduo, \\ ele é um estágio tardio e maduro" (Thomas Mann)
}

Apesar de seu papel central no imaginário humano, o discurso mítico é também cercado por desconfianças. Ao longo de sua história o mito desponta ora como aliado de Ariadne - sendo fonte benfazeja de material estético e de articulação intelectual - ora como companheiro do minotauro - sendo fonte de falácias e desvios da verdade e da técnica.

Segundo Durand (2011), desde a filosofia grega, a oposição entre mythos e logos permitiu uma cisão entre os campos. Ainda que Platão defendesse uma visão mais matizada, em que reconhece na imagem e na analogia uma via válida de acesso ao conhecimento, é a dialética aristotélica que tem premência na constituição das bases do pensamento Ocidental: "Graças à linguagem imaginária do mito, Platão admite uma via de acesso para as verdades indemonstráveis: a existência da alma, o além, a morte, os mistérios do amor ... Ali onde a dialética bloqueada não consegue penetrar, a imagem mítica fala diretamente à alma." (Durand, 2011, pp. 16,17). A filosofia grega clássica considerará o mito e a lógica opostos inconciliáveis, e o raciocínio binário será considerado o único processo para a busca da verdade.

Essa hesitação diante do mito será reincidentemente propagada pelo pensamento ocidental. Em diversos momentos, a mitologia é associada ao primitivismo e à infância: "Não são poucos os esquemas que distinguem três fases na evolução de consciência das luzes, e a primeira fase é invariavelmente o Período do Mito, ou da Fábula, que retrocede até a "infância" da raça humana." (Ruthven, 2010, p. 69)

Em tal direção, o autor destaca que o lluminismo contribuiu consideravelmente para o movimento de "desmitologização" da literatura. Ao colocar a razão no centro das preocupações, instituiu o discurso mítico como a antífrase do discurso racionalista. Mielietinski, em sua Poética do Mito, também sublinha no iluminismo e no positivismo os momentos de maior repulsa ao mito:

Em todo o seu curso, a história da cultura esteve, de uma forma ou de outra, em correlação com a herança mitológica dos tempos primitivos e da Antiguidade, essa relação oscilou fortemente, mas no conjunto a evolução ocorreu no sentido da "desmitologização" (cujo apogeu pode ser 
considerado o lluminismo do século XVIII e o Positivismo do século XIX), e no século XX deparamos com uma súbita "remitologização" (pelo menos em .termos de cultura ocidental) (Mielietinski, 1987, p. 04)

Conforme as reflexões de Ruthven (2010), com o Positivismo e a Revolução Industrial esse movimento de negação ao mito intensificou-se. No contexto da modernização, no qual a natureza é domesticada a fim de permitir o aumento de produção, os deuses pagãos perdem seu lugar no mundo. Segundo Peacock (APUD Ruthven, 2010), as antigas deidades ligadas ao sublime não poderiam habitar espaços utilizados como matéria-prima para o desenvolvimento capitalista: os rios, florestas e bosques, que guardavam o bucolismo mítico, passaram a ser usados para produzir trigo, para a construção de ferrovias, etc.

No mundo industrial e no bojo das descobertas científicas, o mito foi considerado uma maneira ilegítima de apreensão do real. Durand (2011) assinala que o historicismo e o cientificismo desencadearam uma desvalorização completa dos mitos e do imaginário, e permitiram a ascensão do pensamento eurocentrista que julgava as culturas pré-industriais inferiores:

As duas filosofias que desvalorizarão por completo o imaginário, o pensamento simbólico e o raciocínio pela semelhança, isto é, a metáfora são o cientificismo (doutrina que só reconhece a verdade comprovada por métodos científicos) e o historicismo (doutrina que só reconhece as causas reais expressas de forma concreta por um evento histórico) (...) Embora, por um lado, tenha sido a lenta erosão do papel do imaginário na filosofia e epistemologia do Ocidente que possibilitou o impulso enorme do progresso técnico, por outro, o domínio deste poder material sobre as outras civilizações atribuiu uma característica marcante ao "adulto branco e civilizado", separando-o, assim como sua "mentalidade lógica", do resto das culturas do mundo tachadas de "pré-lógicas", "primitivas" ou "arcaicas". (Durand, 2011, pp. 14-15)

Contudo, consoante Mielietinski (1987), no século XX houve um retorno significativo às discussões acerca do mito, sobretudo na literatura. Podemos perceber uma volta expressiva de narrativas míticas na prosa, na poesia e no cinema ocidentais:

A partir do primeiro decênio do século XX, a "remitologização", o "renascimento" do mito se torna um processo tempestuoso, que abrange diversos aspectos da cultura europeia. Os principais elos desse processo não são constituídos pela apologia propriamente dita do mito, na qual ainda podemos discernir a sua singular romantização em contraposição à "prosa" burguesa; são constituídos, em primeiro lugar, pelo reconhecimento do mito como princípio eternamente vivo, que desempenha função prática também na sociedade atual; em segundo pela discriminação, no próprio mito, da sua relação com o ritual e da concepção do eterno repetir-se e, especialmente, em terceiro, pela máxima aproximação até mesmo identificação do mito e 
do ritual com a ideologia e a psicologia, e também com a arte. (Mielietinski, 1987, p. 23)

Esse dado nos levou a refletir se o conceito de Zeitgeist, de Anatol Rosenfeld, pode amparar nossa reflexão sobre a reelaboração do mito das tecelãs na modernidade, uma vez que pudemos mapear o retorno simultâneo a essa temática em literaturas de vários locais.

De certa maneira, a retomada da tecelã-escritora parece trazer consigo a reivindicação de novos espaços para o feminino. Tal reutilização ocorre em diversas latitudes e também tem sido formalizada em diversos gêneros. Podemos citar, na poesia, Sophia de Melo Breyner Andersen e Maria Teresa Horta, que evocam reiteradamente as tecelãs. No romance, temos "Jogo de Fiar", de Patrícia Bins; "Como Água para Chocolate", de Laura Esquivel; "Vulgo Grace", de Margareth Atwood, dentre outros exemplos.

Para Anatol Rosenfeld (1973), o retorno ao mito está ligado a um reencontro com um mundo não-fragmentado e com um estado humano anterior à noção de indivíduo, à velocidade, ao mecanicismo. Diante de um mundo caótico e fragmentado, marcado pela chegada da modernidade, seria um movimento de contestação aos valores vigentes postular um retorno à lógica arcaica, na qual se poderia escapar da individuação e da incoerência do mundo moderno. O retorno dos mitos na literatura expressa "nesta mesma decomposição do indivíduo a sua esperança de, chegado à substância anônima do ente humano, poder vislumbrar a integração no mundo elementar do mito." (Rosenfeld, 1973, p. 88).

Além disso, a narrativa mítica é capaz de resgatar algo próprio do humano:

No fundo e em essência o homem repete sempre as mesmas estruturas arquetípicas - as de Édipo ou de Electra (a própria psicologia recorreu ao mito); as do pecado original, da individuação; da partida da casa paterna, da volta do filho pródigo; de Prometeu, de Teseu no Labirinto - e assim em diante $A$ própria emergência e emancipação do indivíduo racional e consciente é apenas parte daquele "eterno retorno", é um padrão fixo que a humanidade repete na sua caminhada circular através dos milênios. (Rosenfeld, 1973, p. 89)

Ainda na esteira das reflexões de Rosenfeld (1973) e de Mielietinski (1987), podemos afirmar que o mito que retorna nunca está em seu estado puro, idílico, arcaico. Toda retomada é transpassada pelas tensões e dilemas de seu momento histórico, logo, o mito é atualizado e revela que, no bojo de seu retorno, está posta uma crítica à sociedade burguesa e à dilaceração imposta pelo capital: 
Os escritores do século XX utilizaram os mitos tradicionais com um novo tratamento, que expressasse essa nova situação do homem, abandonado na sociedade burguesa, ao passo que na Antiguidade e nas sociedades primitivas os mitos exprimiam pensamentos e sentimentos coletivos, sociais. (Mielietinski, 2006, p. 54)

A individualidade é uma das características centrais que diferenciam as sociedades tradicionais e o homem moderno. Na Antiguidade o mito funcionava como uma comunhão verdadeira com a comunidade e com o mundo natural, enquanto em seu retorno moderno, a mitologia enfatiza paralelamente o desejo de retorno a um equilíbrio com o mundo e a fissura que separa o homem moderno das possibilidades de efetivar tal reconciliação, isto é, "evoca a unidade mítica e revela ao mesmo tempo, na sua própria estrutura, a razão dessa procura saudosa." (Rosenfeld, 1973, p. 90). A retomada mítica escancara a dissociação homem-mundo na fatura fragmentada da narrativa moderna e, ao mesmo tempo, postula um retorno temático ao mito como forma de resgatar algo do humano que está perdido em meio às máquinas:

Não devemos esquecer tampouco que a poética da mitologização não apenas organiza a narrativa, mas serve de meio de descrição metafórica da situação na sociedade moderna (a alienação, a trágica "robinsonada" do indivíduo, o sentimento de inferioridade e impotência do homem particular diante das forças sociais mistificadas) com o auxílio de paralelos dos mitos tradicionais, gerados por outro estágio do desenvolvimento histórico. Por isso, ao serem usados os mitos tradicionais, seu próprio sentido modifica-se acentuadamente, sendo frequentemente substituído por um diametralmente oposto. Isso ressalta, em particular, a comparação de Kafka, que mitologiza diretamente a prosa moderna do cotidiano, com Joyce, que faz experimentações com mitos tradicionais. (Mielietinski, 1987, p. 441)

Nessa perspectiva, o mito é sempre eivado, pintado com tintas modernas que colocam em cena a própria incapacidade de seu retorno, que será sempre falhado, posto que em atrito com as formas do mundo moderno. Essa tensão entre tema e fatura faz do mito um terreno muito fértil para se debater a modernidade e em que medida as rupturas e permanências temático-formais em suas reutilizações encenam valores modernos e demandas modernas impressas sobre estruturas arquetípicas.

A obra mais impactante no romance do século $X X$ que recobra a questão mítica é Ulisses, de Joyce - amplamente discutido por Rosenfeld $(1973,1994)$ e Mielietinski (1987). Contudo, os teóricos sublinham que outros romancistas do século XX resgatam o mito ainda que não de maneira tão explícita quanto Joyce. É 
sobretudo na esfera temporal que o mito penetra a narrativa moderna. Rosenfeld (1994) afirma que no romance moderno de Proust, Joyce e Gide, a mescla temporal entre passado, presente e futuro abre espaço para a presença mítica na narrativa, enquanto em Kafka parece comparecer o mito da frustração do indivíduo.

Mielietinski (1987) destaca ainda que a poética da mitologização chega às literaturas latino-americanas no século XX, sob influxos do Modernismo europeu, mas que se mescla organicamente às culturas locais, permitindo em muitos casos o resgate dos mitos regionais, conforme se vê nas obras de Gabriel Garcia Márquez e Mário de Andrade.

No Brasil, podemos pensar na riqueza mítica do universo poético de Guimarães Rosa, que resgata o universo arcaico sertanejo e renova o mito por meio da linguagem poética; em Nélida Piñon, em cuja obra pulsa a veia mítica grecolatina, galega e bíblica; em Marina Colasanti, que resgata o mito e o conto maravilhoso como meios de contestação da modernidade - os três autores serão aqui contemplados. E também em Clarice Lispector, pois seu "Uma Aprendizagem ou O Livro dos Prazeres" reformula a Odisseia homérica ou em Mário de Andrade e seu Macunaíma, sem nenhum caráter, que revisita os mitos tradicionais brasileiros, concedendo destaque inédito às narrativas indígenas.

Outra questão suscitada pelo mito a merecer uma breve discussão está na indagação: em que medida o modo pelo qual a super-valorização da modernidade e do racionalismo instaura um espaço que se pretende desmitizado, mas que, na prática, propõe o mito de que não há mais mitos, tomando a informação e a técnica na qualidade de novas musas da totalidade:

As técnicas de informação permitem essa posse gigantesca das consciências e o despovoamento do imaginário compatível com uma civilização que conquista o Cosmo e faz a bomba atômica. Reciprocamente, os ídolos e os sacerdotes da nova mitologia reinvestem nessa indústria moderna, e graças a ela, sua potencialidade de crescimento social e econômico. (Durand, 1995, p. 32)

No mundo moderno, negam-se veementemente as potencialidades simbólicas do mito arcaico, e em, contrapartida, proliferam-se mitos políticos e midiáticos, bem como o papel dos bens de consumo na qualidade de via de acesso à completude.

Na esteira da crítica, será necessário questionar se a busca desenfreada pela técnica e pela compreensão totalizante do mundo não é o maior mito da 
modernidade, ainda que pode negue o seu quinhão de especulação e a sua própria fragilidade para decifrar o "real". Nietzsche considerava a ciência e a arte como dois simulacros igualmente distantes da verdade, porém, a arte seria mais verdadeira por admitir seu caráter ficcional, enquanto a ciência afirma-se sob a égide do racional e verdadeiro, ainda que seja também uma construção humana (cf. Nietzsche, 1873).

Em suma, tais pensadores empenhados em compreender a modernidade apontam para o retorno de uma episteme plural, em que a "opacidade" (Glissant, 2011) e o "dilema" (Durand, 1995) instauram uma relação complexa com os objetos de estudo, lógica inerente ao mito.

Não cabe neste estudo postular novos caminhos para a história do pensamento, mas podemos levantar reflexões a partir da natureza ambivalente do mito e indagar se seu retorno não revela a necessidade de se resgatar uma visão mais poética da realidade.

As imagens e os mitos foram relegados ao segundo plano desde a lógica Aristotélica: "Durante oito séculos o Ocidente iria optar pela análise dualista de Aristóteles" (Durand, 1995, p. 21). Tal concepção binária do mundo pressupõe ao mesmo tempo um controle sobre ele e um acabamento que pode enformar a percepção. A opacidade proposta por Glissant (2011) parece, portanto, muito mais interessante enquanto sistema, uma vez que considera o mundo em sua complexidade e ambivalência:

Não apenas consentir no direito à diferença, mas, antes disso, no direito à opacidade, que não é o fechamento em uma autarquia impenetrável, mas a subsistência em uma singularidade não redutível. Opacidades podem coexistir, confluir, tramando os tecidos cuja verdadeira compreensão levaria à textura de certa trama e não à natureza dos componentes. Renunciar, por um tempo talvez, a essa velha assombração de surpreender $o$ fundo das naturezas. Seria grandiosa e generosa a iniciativa de inaugurar tal movimento, cuja referência não seria a Humanidade mas a diferença exultante das humanidades. Caduca, assim, a dualidade de pensar em si mesmo e pensar o outro. Qualquer Outro é um cidadão e não mais um bárbaro. $O$ que está aqui está aberto, tanto quanto o de lá. Eu não saberia projetar de um a outro. O aqui-lá é a trama que não trama fronteiras. O direito à opacidade não estabeleceria o autismo, ele fundamentaria realmente a Relação, em liberdades. (Glissant, 2011, p. 180)

Para o teórico, os problemas são expostos e a reflexão é realizada sem a busca de uma síntese imediata, substituída pelo prisma, pelos matizes complexos, que não podem ser resolvidos pela univocidade - ela própria uma ficção. Desse 
modo, ao abrir espaço para a errância, também se aprofunda a reflexão que não se vê obrigada a uma singularidade redutível.

Jacques Derrida (2002) igualmente questiona a supremacia do logos, que restringe as possibilidades da filosofia. Para ele, o termo logocentrismo ${ }^{80}$ designa o pensamento ocidental clássico, calcado na busca da verdade aristotélica. Derrida (2002) considera-o uma visão eurocêntrica, que julga apenas uma maneira de apreensão do real válida, aquela calcada na lógica, na palavra escrita e no racionalismo. O filósofo enxerga o logocentrismo como uma visão restrita, que impede a busca de novos escopos de reflexão

Logo, na esteira da crítica, o pensamento contemporâneo parece clamar por um modelo em que as tensões não precisem ser resolvidas em uma oposição binária e em que possamos observá-las como benéficas e produtoras da multiplicidade e da pluralidade. Nesse sentido, o raciocínio mítico é um objeto de análise muito profícuo no momento atual, uma vez que resgata uma interação matizada com o mundo.

Em contrapartida, muitos teóricos têm refletido sobre a situação atual do símbolo e do imaginário, questionando se, em um mundo tecnológico e mecanicista, ainda existe espaço para a experiência simbólica. Para Durand (1995), na esteira das reflexões de Lévi-Strauss, o homem moderno ainda pode usufruir e se beneficiar da experiência simbólica e poética, o que aqui será relevante:

Sim, ao homem do século $X X$, que vive numa sociedade industrializada, é permitida uma experiência simbólica autêntica. Ela lhe é mesmo recomendada como antídoto contra a maré avassaladora de imagens passivas que as técnicas do nosso tempo fornecem em superabundância. Sob uma tríplice condição (...) consentir na prenhez simbólica e recusar uma pedagogia totalitária do tempo mecanicista; consentir na inserção numa tradição rica em imagens e recusar as reduções do imaginário a imagens mentais tão pletóricas na nossa "civilização da imagem"; aceitar por fim o esforço da recondução hermenêutica e recusar a idolatria da história." (Durand, 1995, p. 50)

Parece que a conciliação entre mythos e logos como maneiras igualmente válidas, embora distintas, de relação com o mundo é mais profícua do que a sua cisão. Lévi-Strauss (2008, p. 330), ao refletir sobre as articulações entre pensamento mítico e pensamento científico já sugerira que a lógica do pensamento mítico lhe parece tão exigente quanto a do pensamento positivo, considerando ambas semelhantes. Para o teórico, a diferença estaria mais na natureza das coisas sobre

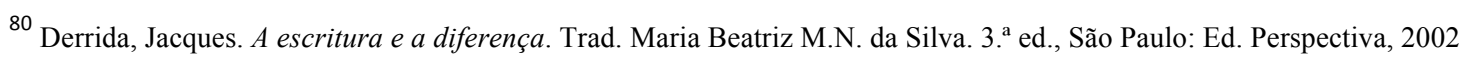


as quais as esferas discutem do que propriamente nas operações intelectuais realizadas, de modo que o homem sempre teria pensado bem.

Consoante a crítica, a hierarquização dos discursos estéticos e científicos não contribui para o desenvolvimento de nenhuma das áreas. O diálogo entre o mito e outros campos, encarados enquanto saberes igualmente legítimos seria um desfecho muito mais proveitoso para a comédia do pensamento humano, conforme A. Jolles:

Como já vimos, o conhecimento procura depreciar o mito e negá-lo mas, por outro lado, não hesita em recorrer ao mito analógico e em tentar realizar-se num mito relativo, sempre que tem consciência das próprias limitações. Por sua parte, o mito aspira frequentemente, quando começa a perder a força de coesão, a desviar-se no sentido do conhecimento, a apoiar-se em seus caminhos, de modo a recuperar 0 fôlego. $O$ conhecimento sob a máscara de mito, 0 mito sob o disfarce de conhecimento - eis dois atores, poderíamos dizer, que gozam de sucesso na ampla comédia do pensamento humano. (Jolles, 1930, p. 98) 